\title{
Sosialt entreprenørskap og sosial innovasjon
}

Kartlegging av innsatser for sosialt entreprenørskap og sosial innovasjon i Norden
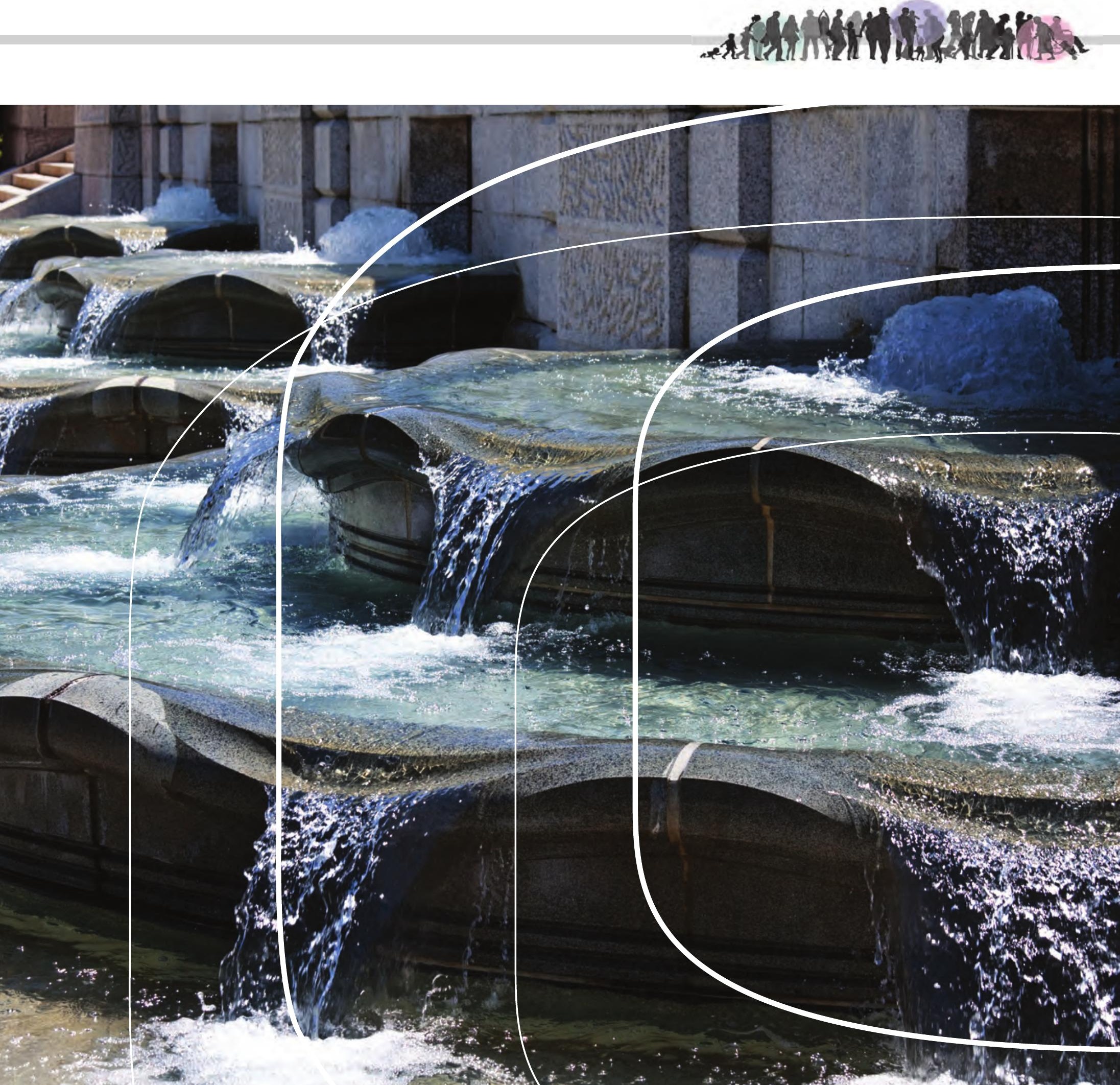

2 norden 



\section{Sosialt entreprenørskap og sosial innovasjon}

Kartlegging av innsatser for sosialt entrepren $\varnothing$ rskap og sosial innovasjon i Norden 
Sosialt entreprenørskap og sosial innovasjon

Kartlegging av innsatser for sosialt entreprenørskap og sosial innovasjon i Norden

ISBN 978-92-893-3898-1 (PRINT)

ISBN 978-92-893-3899-8 (PDF)

ISBN 978-92-893-3900-1 (EPUB)

http://dx.doi.org/10.6027/TN2015-502

TemaNord 2015:502

ISSN 0908-6692

(c) Nordisk ministerråd 2014

Layout: Hanne Lebech

Omslagsfoto: Signelements

Trykk: Rosendahls-Schultz Grafisk

Opplag: 250

Printed in Denmark

Denne rapporten er gitt ut med finansiell støtte fra Nordisk ministerråd. Innholdet i rapporten avspeiler imidlertid ikke nødvendigvis Nordisk ministerråds synspunkter, holdninger eller anbefalinger.

\section{www.norden.org/no/publikasjoner}

\section{Det nordiske samarbeidet}

Det nordiske samarbeidet er en av verdens mest omfattende regionale samarbeidsformer. Samarbeidet omfatter Danmark, Finland, Island, Norge og Sverige samt Færøyene, Grønland og Åland.

Det nordiske samarbeidet er både politisk, økonomisk og kulturelt forankret, og er en viktig medspiller i det europeiske og internasjonale samarbeid. Det nordiske fellesskapet arbeider for et sterkt Norden i et sterkt Europa.

Det nordiske samarbeidet ønsker å styrke nordiske og regionale interesser og verdier i en global omverden. Felles verdier landene imellom bidrar til å styrke Nordens posisjon som en av verdens mest innovative og konkurransekraftige regioner.

\section{Nordisk ministerråd}

Ved Stranden 18

DK-1061 København K

Telefon (+45) 33960200

www.norden.org 


\section{Innhold}

Del 1

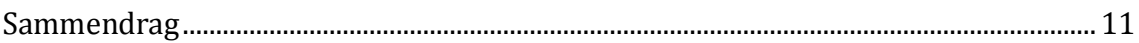

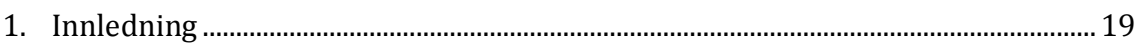

1.1 Bakgrunn ............................................................................................................... 19

1.2 Arbeidsgruppens mandat og sammensetning ............................................... 19

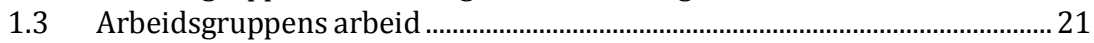

1.4 Arbeidsgruppens forståelse av mandatet....................................................... 21

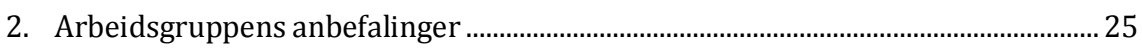

$2.1 \quad$ Nordisk perspektiv og felles nordisk samarbeid ............................................. 25

2.2 Begreper og forståelser - etablere en bedre felles grunn for videre samarbeid................................................................................................................ 26

2.3 Praksis - legge til rette for utveksling av erfaringer med tilretteleggende innsatser ................................................................................. 27

2.4 Forskning og utdanning - styrke kunnskapsgrunnlaget.................................. 27

2.5 Forskning og utvikling - etablere et felles nordisk senter for kunnskapsutvikling og spredning av kunnskap og erfaringer...................... 28

2.6 Politikk - økt samarbeid mellom sektorer og departementer....................... 29

2.7 Sosialt entreprenørskap og sosial innovasjon som tema i

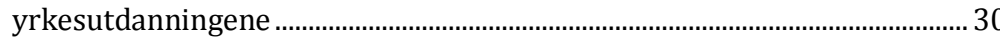

Del 2 31

3. Sosialt entreprenørskap og sosial innovasjon............................................................... 33

3.1 Definisjon på sosialt entreprenørskap og sosial innovasjon .......................... 35

3.2 Sosialt entreprenørskap mellom stat, marked og sivilsamfunn................... 40

3.3 Temaer og definisjoner med røtter i et nordisk perspektiv............................ 48

3.4 Avslutning: Fem punkter som kjennetegner SE og SI i Norden..................... 58

4. Deltakelse i arbeid og samfunnsliv i de nordiske landene.........................................67 67

4.1 Status og utviklingstrekk i Norden................................................................... 67

4.2 Noen grupper har større utfordringer............................................................. 74

4.3 Innsats for å inkludere utsatte grupper i arbeid og samfunnsliv................... 81

Del 3

5. Innsatser for å legge til rette for sosialt entreprenørskap og sosial innovasjon i de nordiske landene ................................................................................ 85

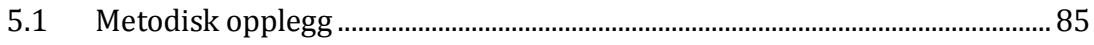

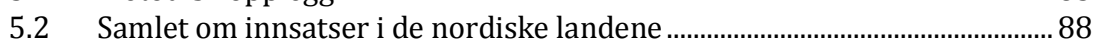

6. Innsatser for sosialt entreprenørskap og sosial innovasjon i Danmark................109

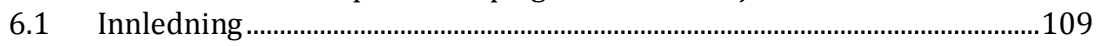

6.2 Respondentene............................................................................................110

6.3 Hvilke hovedtyper innsatser er kartlagt ......................................................111

6.4 I hvilken grad er dette nye innsatser...........................................................111

6.5 Hva er formål og målgruppe for innsatsene ....................................................112 


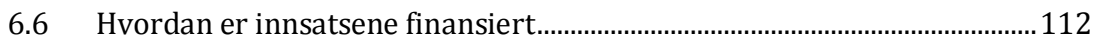

6.7 Hvordan legger innsatsene til rette ...............................................................113

6.8 I hvilken grad fokuserer innsatsene på de fire kjennetegnene ved sosialt entreprenørskap...................................................................................119

6.9 Oppsummerende kommentar............................................................................. 120

7. Innsatser for sosialt entreprenørskap og sosial innovasjon i Finland ....................121

$7.1 \quad$ Innledning ................................................................................................... 121

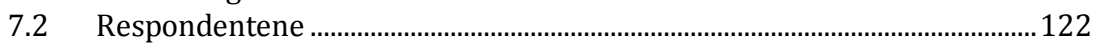

7.3 Hvilke hovedtyper innsatser er kartlagt.......................................................123

7.4 I hvilken grad er dette nye innsatser ..........................................................124

7.5 Hva er formål og målgruppe for innsatsene .....................................................124

7.6 Hvordan er innsatsene finansiert..................................................................126

7.7 Hvordan legger innsatsene til rette ............................................................. 126

7.8 I hvilken grad fokuserer innsatsene på de fire kjennetegnene ved sosialt entreprenørskap.................................................................................... 130

7.9 Oppsummerende kommentar..........................................................................133

8. Innsatser for sosialt entreprenørskap og sosial innovasjon i Island .......................135

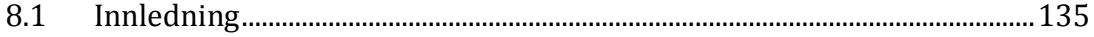

8.2 Respondentene ...............................................................................................136

8.3 Hvilke hovedtyper innsats er kartlagt...........................................................136

8.4 I hvilken grad er dette nye innsatser ...........................................................138

8.5 Hva er formål og målgruppe for innsatsene .....................................................139

8.6 Hvordan er innsatsene finansiert...................................................................141

8.7 Hvordan legger innsatsene til rette .............................................................. 142

8.8 I hvilken grad fokuserer innsatsene på de fire kjennetegnene ved sosialt entreprenørskap..................................................................................144

8.9 Oppsummerende kommentar................................................................... 147

9. Innsatser for sosialt entreprenørskap og sosial innovasjon i Norge ......................149

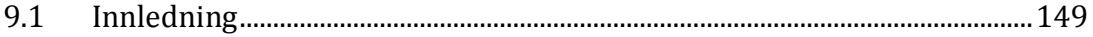

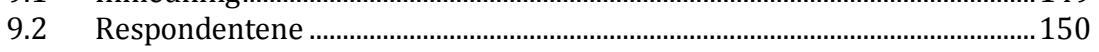

9.3 Hvilke hovedtyper innsatser er kartlagt........................................................150

9.4 I hvilken grad er dette nye innsatser ..............................................................152

9.5 Hva er formål og målgruppe for innsatsene ....................................................152

9.6 Hvordan er innsatsene finansiert..................................................................155

9.7 Hvordan legger innsatsene til rette ............................................................156

9.8 I hvilken grad fokuserer innsatsene på de fire kjennetegnene ved sosialt entreprenørskap.....................................................................................160

9.9 Oppsummerende kommentar.................................................................... 163

10. Innsatser for sosialt entreprenørskap og sosial innovasjon i Sverige....................165

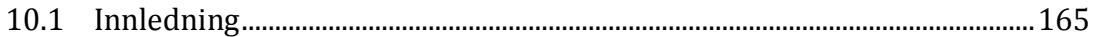

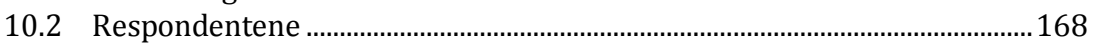

10.3 Hvilke hovedtyper innsatser er kartlagt.......................................................169

10.4 I hvilken grad er dette nye innsatser ...............................................................170

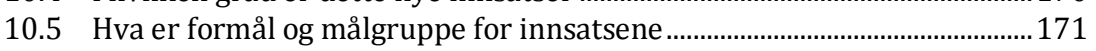

10.6 Hvordan er innsatsene finansiert.................................................................173

10.7 Hvordan legger innsatsene til rette ................................................................174

10.8 I hvilken grad fokuserer innsatsene på de fire kjennetegnene ved sosialt entreprenørskap....................................................................................179

10.9 Oppsummerende kommentar........................................................................ 182 


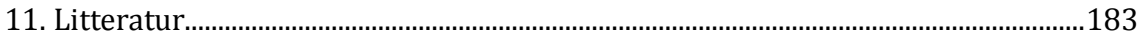

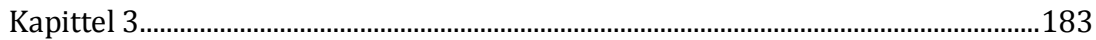

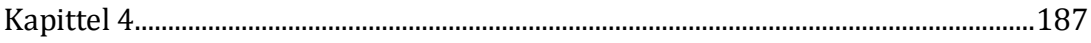

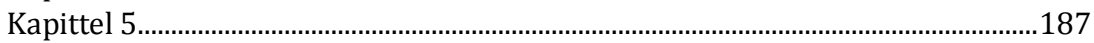

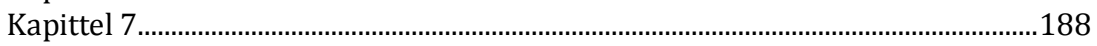

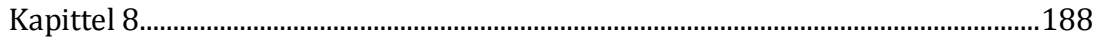

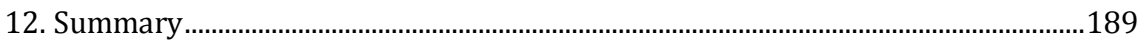

13. Vedlegg 1 Eksempler på begreper og definisjoner i de nordiske landene...........197

13.1 Danmark …….................................................................................................197

13.2 Sverige .......................................................................................................... 198

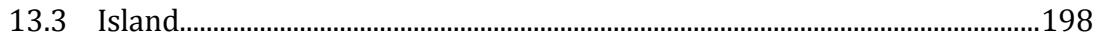

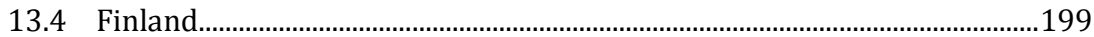

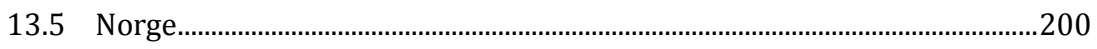

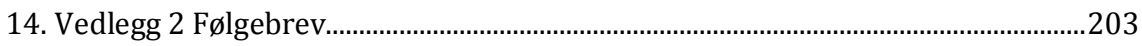

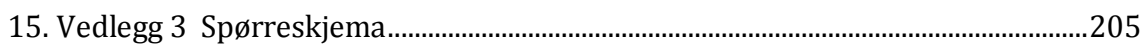



Del 1

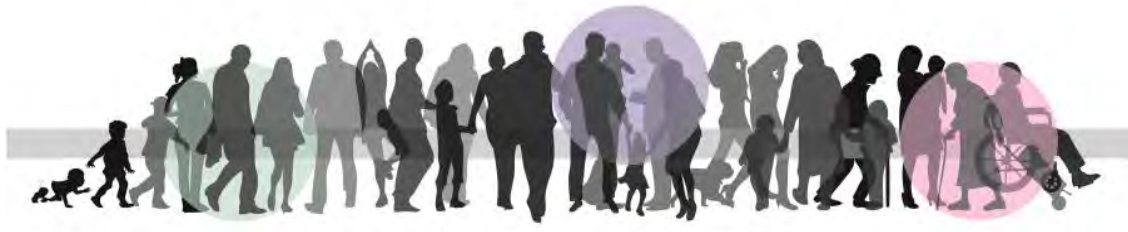





\section{Sammendrag}

I denne rapporten presenteres resultater fra en kartlegging av innsatser for sosialt entreprenørskap og sosial innovasjon i Norden.

Bakgrunnen er utfordringene de nordiske landene står overfor knyttet til å opprettholde og videreutvikle den sosiale velferden. Nordisk Ministerråd (NMR) har ved flere anledninger satt disse utfordringene på dagsorden. Høsten 2012 arrangerte det norske formannskapet et nordisk seminar om sosialt entreprenørskap. En erfaring fra dette seminaret var at det finnes ulike typer innsatser for å legge til rette for sosialt entreprenørskap i de nordiske landene, og at det derved også bør finnes et potensial for gjensidig læring.

NMR besluttet på denne bakgrunn sommeren 2013 å nedsette en arbeidsgruppe som fikk i oppdrag å kartlegge innsatser for sosialt entreprenørskap og sosial innovasjon. Alle de fem nordiske landene og de selvstyrte områdene ble invitert til å delta. Arbeids- sosialdepartementet i Norge ble gitt prosjektansvaret.

Høsten 2013 ble to medlemmer fra hvert land oppnevnt. Medlemmene har bakgrunn fra forvaltning, forskning og utdanning. De selvstyrte områdene valgte å ikke delta.

Hovedmålet for kartleggingen var å øke kunnskapen om innsatser i Norden for sosialt entreprenørskap og sosial innovasjon i arbeidet med å inkludere utsatte grupper i arbeid og samfunnsliv.

Arbeidsgruppens mandat var todelt: Arbeidsgruppen skulle i første fase definere terminologi og emnet for arbeidet, herunder identifisere den delen av det nordiske samarbeidet som kan gi "added value" til arbeidet som allerede pågår i landene og i EU. I andre fase skulle innsatser i de nordiske landene for sosialt entreprenørskap og sosial innovasjon kartlegges.

Vi presenterer i denne rapporten resultatene fra arbeidet som er gjennomført. Rapporten har tre deler.

Del 1 presenterer bakgrunn, formål og hovedinnhold i rapporten. I kapittel 1 presenteres bakgrunn og hovedmål for kartleggingen, samt arbeidsgruppens forståelse av mandatet og begrepene sosialt entreprenørskap og sosial innovasjon, i kapittel 2 gir arbeidsgruppen forslag til videre oppfølging.

I del 2 settes kartleggingen inn i en bredere kontekst. Kapittel 3 omhandler begrepene sosialt entreprenørskap og sosial innovasjon og er 
skrevet av professor Linda Lundgaard Andersen og professor Lars Hulgård ved Roskilde Universitet på oppdrag fra arbeidsgruppen. Forfatterne gjennomgår først hvordan disse begrepene har blitt definert i litteraturen, deretter presenteres noen nordiske perspektiver. Kapittel 4 gir et overblikk over utfordringer knyttet til inkludering av utsatte grupper i arbeid og samfunnsliv i Norden.

Del 3 presenterer resultatene fra kartleggingen, først i kapittel 5 resultater fra det samlede nordiske materialet, deretter i kapitlene 6-10 resultatene for hvert enkelt land.

\section{Sosialt entreprenørskap, sosialøkonomiske virksomheter og sosial innovasjon}

Sosialt entreprenørskap er i arbeidsgruppens mandat forstått som en type virksomhet med følgende tre kjennetegn:

- Er rettet mot et sosialt formål der det er et udekket velferdsbehov.

- Bidrar med nyskapende løsninger på disse utfordringene.

- Drives av de sosiale resultatene, men også av en forretningsmodell som kan gjør virksomheten levedyktig og bærekraftig.

Vi valgte i vårt arbeid å ta utgangspunkt i denne forståelsen og supplere med ytterligere to kjennetegn:

- Involvering av målgruppen for det sosialentreprenøriske arbeidet, medarbeiderne og andre sentrale interessenter.

- Samarbeid på tvers av fagfelt og virksomhetsmodeller.

Vi har her pekt på at sosialt entreprenørskap i mandatet forbindes med forretningsmessige metoder. Vår vurdering er at vi også kan finne sosialt entreprenørielle prosesser og arbeid innen etablerte (offentlige) institusjoner og organisasjoner. Sosialøkonomiske virksomheter kan kjennetegnes ved sosialt entreprenørskap, men ikke nødvendigvis. Sosialt entreprenørskap og sosial innovasjon, slik vi kjenner det i dag, er også nært forbundet, men kan også være to helt avgrensede områder. I dette ligger at vi kan oppnå sosial innovasjon uten forutgående sosialt entreprenørskap. Begrepene sosialt entreprenørskap, sosialøkonomiske virksomheter og sosial innovasjon er nærmere gjennomgått i kapittel 3. 


\section{Gjennomføringen av kartleggingen}

Det følger av mandatet at kartleggingen skal legge vekt på å få fram bredde og variasjon i innsatser, og at den skal gi en beskrivelse, ikke en vurdering av innsatsene.

Ingen av de nordiske landene har noen form for register eller andre former for dokumentasjon av aktører og innsatser for sosialt entreprenørskap og sosial innovasjon. Valg av respondenter har derfor skjedd ved at hvert lands medlemmer har utarbeidet lister med utgangspunkt i egen kunnskap på feltet, nettverk og nettsøk. Det ble også åpnet for at respondentene, kunne foreslå andre eller trekke seg dersom de ikke vurderte egen aktivitet som relevant.

En gjennomgang av hvilke begreper som benyttes i forvaltning og annen praksis i de fem landene, viste at det varierer i hvilken grad begrepene sosialt entreprenørskap er kjent og benyttet. Gjennomgangen viste også at det benyttes flere andre begrep som delvis, men ikke helt, overlapper med forståelsen i mandatet. Vi valgte derfor en åpen tilnærming til hvilke aktører og innsatser som skulle inkluderes. Kartleggingen omfatter således ikke kun innsatser som er direkte rettet mot sosialt entreprenørskap og sosial innovasjon, men også innsatser som kan legge til rette for dette uten at disse begrepene benyttes.

Kartleggingen ble gjennomført i mai og juni 2014. Vi sendte ut et spørreskjema til i alt 193 respondenter, og fikk inn 131 svar, om lag 2/3 av de inviterte. Vi har ingen sikker kunnskap om hvorfor noen ikke valgte å delta. Vår vurdering er likevel at de innsamlede dataene samlet sett inneholder en god bredde og variasjon i innsatser. Det er i alle land kartlagt innsatser både i offentlig, privat og tredje sektor, og innsatser innenfor alle kategorier som er nevnt i mandatet.

Spørreskjemaet som ble benyttet, inneholdt en kombinasjon av strukturerte og åpne spørsmål. Vi presenterer i rapporten både en oversikt over hvilke typer innsatser som finnes og kjennetegn ved disse, og gir eksempler på hvordan innsatsene legger til rette. Alle eksempler som benyttes, er valgt ut for å belyse bredde og variasjon i hva en innsatstype kan innebære i praksis. Det faller utenfor rammen for denne kartleggingen å foreta vurderinger av de ulike innsatsene.

\section{Hvilke typer innsatser er kartlagt}

Kartleggingen viser at det finnes et bredt spekter av innsatser i de nordiske landene.

Det er kartlagt eksempler på følgende typer innsatser i alle land: Finansiering, rådgivning/kompetanseutvikling, inkubatorvirksomhet, nettverksbygging, FoU, utdanning, synliggjøring, lobbing, juridisk rammeverk, strategisk utviklingsarbeid og ivaretakelse av foretaks interesser. 
Kartleggingen viser også at de fleste respondentene har noen hovedinnsatser som følges opp av andre innsatser for å understøtte hovedinnsatsen. Alle respondenter har krysset av for minst to typer innsatser, de fleste for mer enn to, og noen har svart at de tilbyr alle typer innsatser.

Det er både i det samlede materialet og i dataene for hvert enkelt land kartlagt flest eksempler på rådgiving/kompetanseutvikling, synliggjøring og nettverksbygging. Blant innsatser med fokus på rådgivning/kompetanseutvikling finner vi ulike typer kurs og annen opplæring, konferanser, workshops, veiledning og rådgivning gjennom deltakelse i styrer. Nettverksbygging handler både om etablering av faste strukturer rundt definerte nettverk (nettverksforeninger), og ad hoc grupper etablert i ulike organisasjoner, bruk av workshops og seminarer. Synliggjøring handler om flere av de samme aktivitetene og ulike former for kunnskapsdeling.

Vi gir i kapitlene 5-10 eksempler på innsatser innenfor alle de kartlagte kategoriene.

Bak dette overordnede bildet skjuler det seg en god del variasjon mellom landene. Det gjelder blant annet hvor mange innsatser som er kartlagt innenfor hver kategori og kjennetegn ved de ulike innsatsene. Et land kan i noen tilfeller kun ha ett eksempel innen en kategori, andre land en lang rekke eksempler. Og for eksempel i kategorien utdanning, kan det skjule seg både et masterprogram i sosialt entreprenørskap ved et universitet og mindre og mer kortvarige kurs.

Det er også stor variasjon i hva som er formål og målgruppe for innsatsene. Som tidligere nevnt varierer det mellom de nordiske landene i hvilken grad begrepene sosialt entreprenørskap og sosial innovasjon er kjent og blir benyttet. Dette gjenspeiler seg også i de innsatsene som er kartlagt.

Vi finner både i det danske, svenske og norske materialet flere eksempler både på innsatser som retter seg direkte mot sosialt entreprenørskap og sosial innovasjon i arbeidet for å inkludere utsatte grupper i arbeid og samfunnsliv og innsatser retter seg direkte mot sosialt entreprenørskap og sosial innovasjon generelt. Vi ser samtidig at i Danmark er flere av innsatsene knyttet til begrepet sosialøkonomiske virksomheter og i Sverige til begreper som sosiale arbeidsintegrerende foretak og samfunnsentreprenørskap.

I det finske innsamlede materialet finnes ingen egne innsatser for sosialt entreprenørskap og sosial innovasjon, men eksempler på innsatser 
for å fremme sysselsetting og næringsvirksomhet, innsatser for å legge til rette for samfunnsmessige foretak og innsatser for å inkludere utsatte grupper i arbeid og samfunnsliv. ${ }^{1}$ Det finnes heller ingen egne innsatser for sosialt entreprenørskap og sosial innovasjon i det islandske materialet, men innsatser som retter seg mot entreprenørskap og innovasjon, samt innsatser rettet mot tredjesektororganisasjoner som arbeider med inkludering av utsatte grupper generelt. Disse innsatsene kan bidra til sosialt entreprenørskap og sosial innovasjon, selv om de ikke er direkte rettet mot dette.

Det er vårt generelle inntrykk at innsatser som er direkte innrettet mot sosialt entreprenørskap og sosial innovasjon i arbeidet med å inkluderer utsatte grupper i arbeid og samfunnsliv er av nyere dato.

\section{I hvilken grad har innsatsene fokus på kjennetegnene ved sosialt entreprenørskap}

Vi har som tidligere nevnt i vår forståelse av sosialt entreprenørskap valgt å trekke fram fire kjennetegn. Det er utvikling og utprøving av nye løsninger, involvering av målgruppen for det sosialentreprenøriske arbeid, samarbeid på tvers av fagfelt og virksomhetsmodeller, og bærekraft (økonomisk og samfunnsøkonomisk).

Det samlede materialet viser at en stor andel av respondentene "til en viss grad" eller "i stor grad" har fokus på disse kjennetegnene. Andelen varierer fra om lag $80 \%$ for involvering av målgruppen til over $90 \%$ for fokus på nye løsninger. Det er noe, men ikke stor variasjon mellom landene.

Fokus på de fire kjennetegnene ved sosialt entreprenørskap kan således synes å være noe respondentene har fokus på, selv om innsatsen ikke direkte er rettet mot sosialt entreprenørskap.

\section{Respondentens vurderinger av hindre og behov for nye innsatser}

Respondentene ble stilt spørsmål om sine vurderinger av de viktigste hindre for sosialt entreprenørskap og sosial innovasjon, og behovet for nye innsatser. Svarene fra respondentene kan og må forstås ut fra den nasjonale konteksten og området respondentene arbeider på. Det er samtidig et generelt inntrykk at mange av de samme hindre og behov for nye innsatser er å finne i svarene fra respondenter i alle land. Disse kan oppsummeres i følgende hovedkategorier:

${ }^{1}$ Informasjonen kan være mangelfull pga. lav deltakelse i spørreskjemaundersøkelsen i Finland. 
- Manglende tilgang til finansiering og utilstrekkelige eller manglende støttestrukturer: Som svar på disse utfordringene pekes på behov for bedre finansieringsmuligheter både fra det offentlige og andre finansieringskilder.

- Regelverk og praktisering av regelverk: Det er særlig utfordringer knyttet til regelverk for offentlige anskaffelser og praktisering av dette som nevnes. Det pekes på behov for endringer i dette regelverket, og at kvalitet, samfunnsansvar og sosial verdi i større grad bør etterspørres.

- Manglende kunnskap om sosialt entreprenørskap og sosial innovasjon: Det pekes både på manglende kunnskap i samfunnet generelt og blant offentlige myndigheter spesielt. Som svar på disse utfordringene, nevnes en stor bredde av innsatser, herunder forskning og utdanning, kartlegging og utveksling av erfaringer med gode eksempler, og informasjonskampanje.

- Holdning, kultur og organisering i det offentlige: Det pekes på et motsetningsforhold mellom sosialt entreprenørskaps tverrsektorielle og tverrfaglig karakter og offentlige aktørers organisering i spesialiserte enheter. Det pekes også på manglende kompetanse og insentiver til å arbeide på tvers. Som svar på disse utfordringene pekes på behov for å se nærmere på hvordan strukturer og systemer kan mykes opp, slik at de ikke bremser for sosialt entreprenørskap. Det er behov for tettere samarbeid mellom offentlig myndigheter og privat og frivillig sektor om løsning av velferdsutfordringer.

\section{Arbeidsgruppens anbefalinger til videre oppfølging}

Sosialt entreprenørskap og sosial innovasjon har gjennom flere år blitt vist økende oppmerksomhet og interesse. Det er i EU tatt initiativ til en rekke programmer og tiltak for å legge til rette for aktivitet på området. Vi gir i denne rapporten et lite innblikk i hvilke innsatser som finnes i de nordiske landene med vekt på innsatser som er relevante for arbeidet med å inkludere utsatte grupper i arbeid og samfunnsliv.

Vår vurdering er at felles utfordringer for de nordiske landene knyttet til å videreutvikle den nordiske velferdsmodellen gjør det både relevant og interessant med et videre felles nordisk samarbeid der det nordiske perspektivet ivaretas. Kjennetegn ved sosialt entreprenørskap og samspillet med en bred offentlig sektor i de nordiske landene, kan være forskjellig fra tilsvarende samspill i land med andre velferdsmodeller. Et felles nordisk samarbeid kan skje på ulike områder og måter. 
Vi presenterer her noen anbefalinger til videre oppfølging. Anbefalingene er basert på erfaringer vi har gjort gjennom dette arbeidet, svarene fra respondentene og kompetansen som arbeidsgruppen samlet besitter.

1. Begreper og forståelser - etablere en bedre felles grunn for videre samarbeid.

Vår erfaring er at ulike begreper og definisjoner på dette området bidrar til at det i noen tilfelle kan være vanskelig å vite hva man snakker om, og om man snakker om det samme.

- Det tas et initiativ til et arbeid for å gjøre begreper og definisjoner som benyttes i de nordiske landene på dette området bedre kjent og forstått.

- NMR identifiserer noen kjennetegn ved sosialt entreprenørskap som legges til grunn for eget arbeid på området.

2. Praksis - legge til rette for utveksling av erfaringer med ulike typer innsatser.

Kartleggingen som presenteres i denne rapporten gir et lite innblikk i bredde og variasjon i innsatser i de nordiske landene. Hva er så erfaringene med disse innsatsene? I hvilken grad bidrar innsatsene til oppsatte mål og i hvilken grad er innsatsene et godt svar på de utfordringene som sosiale entreprenører møter?

- Det tas initiativ til en nordisk konferanse med formål å utveksle kunnskap og erfaring med ulike typer innsatser for sosialt entreprenørskap og sosial innovasjon.

3. Forskning og utdanning - styrke kunnskapsgrunnlaget.

Lars Hulgård og Linda Lundgaard Andersen gir i kapittel 3 en kort status for forskning og utredning på feltet i de nordiske landene. Feltet er fremdeles forholdsvis nytt, og det pekes på flere tema og problemstillinger av felles nordisk relevans. Behov for økt kunnskap om sosialt entreprenørskap og sosial innovasjon, trekkes også frem av respondentene i kartleggingen.

- Det tas initiativ til et arbeid med formålet å styrke forskning og høyere utdanning på området i de nordiske landene. Arbeidet deles inn i to trinn: Først gjennomføres en kartlegging av forskning og høyere utdanning som allerede pågår. Deretter foretas en vurdering av en mulig utforming av et felles nordisk forskningsprogram med fokus på tema av spesielt relevans for de nordiske landene, og det vurderes mulige tiltak for å utvikle eksisterende tilbud om høyere utdanning. 
4. Forskning og utvikling - etablere et felles nordisk senter for kunnskapsutvikling og spredning av kunnskap.

Kartleggingen gir eksempler på flere miljøer - både store og godt etablerte og andre mindre miljøer - som arbeider med forskning, kunnskapsutvikling og spredning av kunnskap og erfaringer på feltet. Enkelte av disse har etablert samarbeid med andre land i Norden, og det er også etablert et samarbeid om forskning mellom flere av de nordiske landene gjennom forskningsnettverket SERNOC. Vår vurdering er at det bør bygges videre på dette samarbeidet.

- Det etableres en felles nordisk senter for kunnskapsutvikling og spredning av kunnskap og erfaringer på feltet. Senteret kan være fysisk og/eller virtuelt og bygge på eksisterende nordiske og/eller nasjonale strukturer og samarbeid.

5. Politikk - økt samarbeid mellom sektor og departement.

Manglende samarbeid på tvers og silotenkning i det offentlige peker på som et hinder for sosialt entreprenørskap og sosial innovasjon i alle land. Gitt et politisk ønske om å bidra til å utvikle og styrke sosialt entreprenørskap og sosial innovasjon, ser vi et behov for å adressere feltet på et mer tverrdepartementalt og strategisk plan.

- Nasjonale myndigheter oppfordres til å adressere feltet på et mer tverrdepartementalt og strategisk plan. Blant aktuelle tema i et tverrdepartementalt samarbeid er erfaringer og utfordringer knyttet til anskaffelsesregelverket, samt ulike finansieringsløsninger og andre støttestrukturer for sosialt entreprenørskap og sosial innovasjon.

6. Sosialt entreprenørskap og sosial innovasjon som tema i yrkesutdanningene.

Sosialt entreprenørskap, sosialøkonomiske virksomheter, sosiale foretak og sosial innovasjon berører mange samfunnsområder, og dermed ulike yrkesgrupper i økende grad. Det er vårt inntrykk at dette i dag ikke speiles i utdanningsplaner, kurslitteratur mv.

- Nasjonale myndigheter oppfordres til å vurdere behovet for utvikling av dette området. 


\section{Innledning}

\subsection{Bakgrunn}

De nordiske landene står i dag overfor store utfordringer knyttet til å opprettholde og videreutvikle den sosiale velferden. Nordisk Ministerråd (NMR) har ved flere anledninger og på ulike måter satt disse utfordringene på dagsorden.

I 2012 ble det som en del av det norske formannskapet i NMR avholdt et nordisk seminar om sosialt entreprenørskap. Seminaret ga et innblikk i sosialt entreprenørskap i praksis og hvilke utfordringer sosiale entreprenører møter ved oppstart og i utvikling av virksomheten. Ulike former for samspill mellom aktører som legger til rette for sosialt entreprenørskap og sosiale entreprenører ble også presentert.

En erfaring fra seminaret er at det finnes flere forskjellige typer tilretteleggende innsatser i de nordiske landene, og at det derved også bør være et potensial for gjensidig læring.

Nordisk Ministerråd besluttet på denne bakgrunn høsten 2013 å nedsette i arbeidsgruppe som fikk i oppdrag å kartlegge innsatser for sosialt entreprenørskap og sosial innovasjon i de nordiske landene.

\subsection{Arbeidsgruppens mandat og sammensetning}

Følgende framgår av mandatet for arbeidsgruppen:

"Hovedmålet med denne kartleggingen er å øke kunnskapen om innsatser i Norden for å legge til sosialt entreprenørskap og sosial innovasjon i arbeidet med å inkludere utsatte grupper i arbeid og samfunnsliv. Hovedtema for kartleggingen er således ikke de sosiale entreprenørene, men innsatser for å legge til rette for denne typen virksomhet og innovasjon."

Det framgår videre at arbeidsgruppens rapport vil inn gå i et mer langsiktig arbeid der formålet er erfaringsutveksling mellom berørte aktører og styrking av kunnskapsgrunnlaget for politikkutvikling på området i Norden. 
Arbeidsgruppens arbeid er delt inn i to faser:

I første fase skal arbeidsgruppen definere terminologi og emnet for arbeidet, herunder identifisere den delen av det nordiske samarbeidet som kan gi "added value" til det arbeidet som allerede pågår i landene og i EU. Den første fasen skal oppsummeres i et notat/delrapport til EK-S og EK-U.

I andre fase skal arbeidsgruppen kartlegge innsatser i de nordiske landene som har som formål å legge til rette for sosialt entreprenørskap og sosial innovasjon. Kartleggingen skal avgrenses til innsatser for å legge til rette for sosialt entreprenørskap og sosial innovasjon i arbeidet for å inkludere utsatte grupper i arbeid og aktivitet.

Det følger av mandatet at hvert medlemsland skulle utpeke to medlemmer til arbeidsgruppen, hvorav ett medlem fra forvaltningen og ett medlem fra praksis eller forskning. De selvstyrte områdene ble også invitert, men valgte ikke å delta.

Arbeidsgruppen har bestått av medlemmer som på ulike måter har erfaring fra arbeid med sosialt entreprenørskap, sosial innovasjon og utsatte grupper. Medlemmene representerer både forvaltning, forskning og utdanningsinstitusjoner. Flere av medlemmene har også arbeidet feltnært med utsatte grupper, samt har fulgt sosiale entreprenørers arbeid i praksis.

Følgende har deltatt i arbeidsgruppen:

\section{Danmark}

- Lars Hulgård, professor, Center for Socialt Entreprenørskab, Roskilde Universitet.

- Ulrik Boe Kjeldsen, fullmektig, Vækstcenter for socialøkonomiske virksomheder, Socialstyrelsen.

\section{Finland}

- Harri Kostilainen, forskare, Diaconia University of Applied Sciences.

- Markus Seppelin, konsultativ tjänesteman, Social- och hälsovårdsministeriet.

\section{Island}

- Steinunn Hrafnsdóttir, dosent, Fakultet for Socialt Arbete, Center for tredje sektor, Islands Universitet.

- Gudrun Sigurjonsdóttir, seniorrådgiver, Välferdsministeriet. 


\section{Sverige}

- Eva Johansson, handläggare entreprenörskap, Tillväxtverket.

- Hanna Sigsjö, verksamhetsledare, Mötesplats Social Innovation ved Malmö Högskola.

Norge

- Karin Gustavsen, samfunnsforsker, Høgskolen i Telemark.

- Aase Lunde, seniorrådgiver, Arbeids- og sosialdepartementet (leder).

Arbeids- og sosialdepartementet i Norge har vært prosjekteier og ansvarlig for sekretariatet for arbeidsgruppen. I sekretariatet har deltatt Stine Lien, Husbanken (fra oppstart til mars 2014), Tormod Moland, Arbeids- og velferdsdirektoratet (fra mai til avslutning) og Tor Morten Normann, Arbeids- og sosialdepartementet (fra juni til avslutning).

\subsection{Arbeidsgruppens arbeid}

Arbeidsgruppen holdt sitt oppstartmøte i november 2013 og leverte sin sluttrapport i oktober 2014. Det har i denne perioden vært avholdt åtte fysiske møter, hvorav to i henholdsvis Malmø, København og Oslo, og ett i henholdsvis Helsingfors og Stockholm. ${ }^{2}$ I tillegg til disse møtene har det vært avholdt et siste møte kun på videokonferanse.

\subsection{Arbeidsgruppens forståelse av mandatet}

Arbeidsgruppen oppfatter at hovedtema for kartleggingen skal være innsatser for å legge til rette for sosialt entreprenørskap og sosial innovasjon, og ikke de sosiale entreprenørene.

Kartleggingen skal omfatte alle typer innsatser i offentlig regi og privat regi. Som eksempler er i mandatet nevnt utdanning og opplæring, $\varnothing$ konomiske rammebetingelser og økonomisk støtte, kompetanse- og nettverksbygging, juridiske rammebetingelser og regelverk, samt strategier og planer.

2 På fire av disse møtene har det vært benyttet videokonferanseutstyr. 
Det skal legges vekt på å få fram bredde og variasjon i innsatser. Det kan være innsatser som bidrar til sosialt entreprenørskap og sosial innovasjon generelt eller i arbeidet med å inkludere utsatte grupper i arbeid og samfunnsliv spesielt.

Arbeidsgruppen oppfatter dette som et ønske om en forholdsvis bred tilnærming, og at fokus skal være på innsatsene og hvordan disse legger til rette, og ikke på aktørene.

Vi oppfatter at målet ikke skal være å gjennomføre en fullstendig kartlegging, men å synliggjøre bredde og variasjon. Å gjøre en kartlegging av alle aktuelle og relevante innsatser ville uten tvil vært en umulig oppgave innenfor rammen som er satt for dette arbeidet. Å synliggjøre bredde og variasjon er i utgangspunkt enklere, men heller ikke en enkel oppgave når det fullstendige bildet ikke er kjent.

Vi har til grunn for kartleggingen valgt å legge en forholdsvis vid forståelse av hva som kan være innsatser for sosialt entreprenørskap og sosial innovasjon i arbeidet for å inkludere utsatte grupper i arbeid og samfunnsliv.

Vi har forsøkt å finne fram til både innsatser som er rettet spesielt mot sosialt entreprenørskap og sosial innovasjon i arbeidet for å inkludere utsatte grupper og innsatser med bredere relevans. Vi har lagt vekt på å finne fram til innsatser både i regi av offentlig, privat og tredjesektor og forskjellige innsatstyper.

Arbeidsgruppen oppfatter at vi kun skal gi en beskrivelse, ikke en vurdering av de ulike innsatsene. Det sies i mandatet at kartleggingen først og fremst skal ha et praktisk og deskriptivt formål. Dette innebærer at vi gjennom denne kartleggingen ikke har samlet inn informasjon eller gjort vurderinger som gjør at vi i denne rapporten kan presentere eksempler på "beste praksis". Alle eksempler som benyttes, er valgt ut for å belyse bredde og variasjon og hva en innsatstype kan innebære i praksis.

Sosialt entreprenørskap forstås i mandatet som en type virksomhet med følgende kjennetegn:

- Er rettet mot et sosialt formål/udekket velferdsbehov.

- Bidrar med nyskapende løsninger på disse utfordringene.

- Drives av de sosiale resultatene, men også av en forretningsmodell som kan gjør virksomheten levedyktig/bærekraftig. 
Arbeidsgruppen ønsker å supplere denne forståelsen med ytterligere to kjennetegn:

- Målgruppemedvirkning - involvering av målgruppe, medarbeidere (kan være samme gruppe) og andre sentrale interessenter.

- Samarbeid på tvers av fagfelt og virksomhetsmodeller.

I målgruppemedvirkning ligger at målgruppen for det sosialentreprenøriske arbeidet, har innflytelse og medvirker. Denne medvirkningen kan foregå på ulike nivåer, både ved at målgruppen er aktiv i tiltaksutformingen, medeiere av en virksomhet, medlemmer i styrer etc. Samarbeid på tvers av fagfelt og virksomhetsmodeller der partene samspiller på nye måter, er også et viktig kjennetegn ved sosialt entreprenørskap.

Vi vil peke på at sosialt entreprenørskap i mandatet forbindes med forretningsmessige metoder. Vår vurdering er at man også kan finne sosialt entreprenørielle prosesser og arbeid innen etablerte (offentlige) institusjoner og organisasjoner. Sosialøkonomiske virksomheter og sosiale foretak kan kjennetegnes ved sosialt entreprenørskap, men ikke nødvendigvis. Vår vurdering er at sosialt entreprenørskap og sosial innovasjon, slik vi kjenner det i dag, er nært forbundet, men også kan være to helt avgrensede områder. I dette ligger at vi kan oppnå sosial innovasjon uten forutgående sosialt entreprenørskap. Begrepene sosialt entreprenørskap, sosialøkonomiske virksomheter og sosial innovasjon er nærmere gjennomgått i kapittel 3.

Arbeidsgruppen foretok i den innledende fasen av arbeidet av en gjennomgang av begreper og definisjoner som benyttes i forvaltning og annen praksis i de nordiske landene. Gjennomgangen viste at det benyttes en rekke forskjellige begrep som delvis, men ikke helt overlapper forståelsen i mandatet og de suppleringer som her er gitt. Se vedlegg 1 for eksempler på disse.

Vi vurderte det derfor som mest hensiktsmessig å velge en åpen tilnærming til kartleggingen for å kunne fange opp bredde og variasjon i innsatsene for sosialt entreprenørskap og sosial innovasjon i Norden. 



\section{Arbeidsgruppens anbefalinger}

Arbeidsgruppen er i mandatet bedt om å komme med anbefalinger til videre oppfølging.

Våre anbefalinger vil være basert på erfaringer vi har gjort i arbeidet, svarene fra respondentene og kompetansen arbeidsgruppen samlet besitter.

\subsection{Nordisk perspektiv og felles nordisk samarbeid}

Nordisk Ministerråd har gjennom å ta initiativ til denne kartleggingen bidratt til å sette på dagsorden et tema av stor felles interesse for de nordiske landene.

De nordiske landene står alle overfor utfordringer knyttet til å opprettholde og videreutvikle den sosiale velferden.

Sosialt entreprenørskap og sosial innovasjon har gjennom flere år blitt vist økende oppmerksomhet og interesse i EU, og det er tatt initiativ til en rekke programmer og tiltak for å legge til rette for aktivitet på dette området. Vi gir i denne rapporten et lite innblikk i hvilke innsatser som finnes i de nordiske landene med vekt på innsatser som er relevante for arbeidet med å inkludere utsatte grupper i arbeid og samfunnsliv.

Arbeidsgruppen er i mandatet bedt om å vurdere om et felles nordisk samarbeid på dette området kan tilføre noe ekstra, "en added value", utover det som allerede foregår i EU og i landene.

Politikk og programmer på EU-nivå legger både rammer for og gir mulighet for utvikling av dette feltet $i$ de nordiske landene.

Vår vurdering er at felles utfordringer for de nordiske landene knyttet til å videreutvikle den nordiske velferdsmodellen gjør det både relevant og interessant med et felles nordisk samarbeid der det nordiske perspektivet ivaretas. Kjennetegn ved sosialt entreprenørskap og samspillet med en bred offentlig sektor i de nordiske landene kan være forskjellig fra tilsvarende samspill i land med andre velferdsmodeller. Et felles nordisk samarbeid kan skje på ulike områder og måter. Vi vil her komme med noen anbefalinger for videre oppfølging. 


\subsection{Begreper og forståelser - etablere en bedre felles grunn for videre samarbeid}

Vi har gjennom arbeidet med kartleggingen fătt et innblikk i mangfoldet av begreper og definisjoner som benyttes på dette feltet i de nordiske landene.

Vår erfaring er at ulike begreper og definisjoner bidrar til at det i noen tilfelle kan være vanskelig å vite hva man snakker om, og om man snakker om det samme.

Blant begreper som benyttes er sosialt entreprenørskap, samfunnsentreprenørskap, sosial innovasjon, sosialøkonomiske virksomheter, sosiale virksomheter, sosiale foretak, samfunnsmessige foretak, og tredje sektor (frivillige) organisasjoner. Noen begreper er forholdsvis nye, andre har lengre røtter i de nordiske landene. Hva er likt, hva er forskjellig og hvordan er disse forbundet med hverandre? Disse spørsmålene gjelder også flere andre nærliggende begreper som sosialøkonomi, solidaritetsøkonomi og alternativ økonomi.

Arbeidsgruppens vurdering er at en viktig forutsetning for videre nordisk samarbeid på området, er å etablere en bedre felles grunn å stå på. Det er behov for at vi blir bedre kjent med hvilke begreper og definisjoner som benyttes i de ulike landene, og på hvilken måte disse benyttes. Det kan også etter vår vurdering være nyttig å identifisere noen kjennetegn ved sosialt entreprenørskap som kan legges til grunn for Nordisk Ministerråds videre arbeid på området. Et slikt arbeid vil også kunne tilføre verdi på nasjonalt nivå.

\section{Forslag}

- Det tas initiativ til et arbeid for å gjøre begreper og definisjoner som benyttes i de nordiske landene på dette området bedre kjent og forstått.

- Nordisk Ministerråd identifiserer noen kjennetegn ved sosialt entreprenørskap som legges til grunn for eget arbeid på området. Det henvises i den sammenheng til forståelsen arbeidsgruppen har lagt til grunn for denne kartleggingen. Vår vurdering er at denne kan danne grunnlaget for en videre utvikling av felles begrepsforståelse.

Produktet av et slikt arbeid kan eksempelvis være en tekst på nettsiden til NMR. 


\subsection{Praksis - legge til rette for utveksling av erfaringer med tilretteleggende innsatser}

Kartleggingen som presenteres i denne rapporten, gir et lite innblikk i bredde og variasjon i innsatser i nordiske landene for å legge til rette for sosialt entreprenørskap og sosial innovasjon.

Hva er så erfaringene med disse innsatsene? I hvilken grad bidrar innsatsene til oppsatte mål, og i hvilken grad er de et godt svar på de utfordringene som sosiale entreprenører møter?

Dette er spørsmål som faller utenfor vårt mandat å besvare, men som vi vil anbefale at det jobbes videre med.

Svarene fra respondentene i denne kartleggingen gir et lite innblikk i hvilke hindre og behov for nye innsatser som finnes, se kapittel 5. Vi har innenfor rammen av denne kartleggingen ikke hatt mulighet for å stille samme spørsmål til utøverne/de sosiale entreprenørene.

Vår vurdering er at det i en videre oppfølging er behov for å se nærmere på hvordan man på en god måte kan legge til rette for sosialt entreprenørskap og sosial innovasjon både generelt og i arbeidet med å legge til rette for inkludering i arbeid og samfunnsliv spesielt. Det vil i denne sammenheng også være aktuelt å se på i hvilken grad eksisterende støttestrukturer for tradisjonelt entreprenørskap og innovasjon legger til rette, og om disse eventuelt kan tilpasses, slik at de fanger opp entreprenørskap og innovasjon med et sosialt fokus.

\section{Forslag}

- Det tas initiativ til en nordisk konferanse om innsatser for sosialt entreprenørskap og sosial innovasjon. Formålet vil være å utveksle kunnskap og erfaringer med ulike innsatser for sosialt entreprenørskap og sosial innovasjon. Konferansen kan oppsummeres i en kort rapport som gjøres tilgjengelig på nettsidene til NMR.

\subsection{Forskning og utdanning - styrke kunnskapsgrunnlaget}

Lars Hulgård og Linda Lundgaard Andersen gir i kapittel 3 en kort status for forskning og utredning på feltet. Det framgår at sosialt entreprenørskap og sosial innovasjon fremdeles er forholdsvis nytt som forskningsfelt i Norden, og det pekes på flere tema og problemstillinger av felles nordisk relevans. Behov for økt kunnskap om sosialt entreprenørskap og 
sosial innovasjon trekkes også fram av respondenter i alle land som svar på spørsmål om behov for nye innsatser, se kapittel 5 .

Vår vurdering er at det både for et videre felles nordisk samarbeid og for politikkutvikling i hvert enkelt land, er behov for å etablere et bedre kunnskapsgrunnlag på området.

Denne kartleggingen har kun gitt et lite innblikk i tilbud om utdanning på høyere nivå på området. Vår vurdering er at det også er behov for å få nærmere kunnskap om disse tilbudene.

\section{Forslag}

- Det tas initiativ til et arbeid med formål å styrke forskning og høyere utdanning på området i de nordiske landene. Arbeidet deles inn i to trinn: Først gjennomføres en kartleggingen av forskning og høyere utdanning som allerede pågår. Deretter foretas en vurdering av en mulig utforming av et felles nordisk forskningsprogram (4-5 år) med fokus på tema av spesiell relevans for de nordiske landene, og mulige tiltak for å utvikle eksisterende tilbud om høyere utdanning.

Blant mange aktuelle tema for videre forskning vil vi her kort peke på behov for mer kunnskap om sosialt entreprenørskap og den nordiske velferdsmodellen, herunder samspill mellom sosialt entreprenørskap og en bred offentlig sektor som kjennetegner de nordiske landene, og effekten og verdien av sosialt entreprenørskap.

\subsection{Forskning og utvikling - etablere et felles nordisk senter for kunnskapsutvikling og spredning av kunnskap og erfaringer}

Det presenteres i denne rapporten flere eksempler på miljøer - både store, godt etablerte og mindre miljøer - som arbeider med forskning, kunnskapsutvikling og spredning av kunnskap og erfaringer på feltet i Norden. Enkelte av disse har også et etablert samarbeid med andre land i Norden, og det er etablert et samarbeid om forskning også mellom flere av de nordiske landene gjennom forskningsnettverket SERNOC.

Vår vurdering er at man bør bygge videre på og videreutvikle dette samarbeidet. 


\section{Forslag}

- Det etableres et felles nordisk senter for kunnskapsutvikling og spredning av kunnskap og erfaringer på feltet. Senteret kan være fysisk og/eller virtuelt og bygge på eksisterende nordiske og/eller nasjonale strukturer og samarbeid. Utøvere på området bør også være en del av et slikt senter.

Blant aktuelle oppgaver for et senter vil være å støtte og samordne forskning fra andre aktører. Et viktig fokus bør være på utvikling og spredning av kunnskap og erfaringer om hvordan man kan legge til rette for utvikling av området.

\subsection{Politikk - økt samarbeid mellom sektorer og departementer}

Gitt et politisk ønske om å bidra til å utvikle og styrke sosialt entreprenørskap og sosial innovasjon, ser arbeidsgruppen et behov for å adressere feltet på et mer tverrdepartementalt og strategisk plan.

Samarbeid på tvers er et kjennetegn ved sosialt entreprenørskap som trekkes fram i mange definisjoner. Det framgår av svarene fra respondenter i denne kartleggingen på spørsmålene om hindre og behov for nye innsatser, at mange opplever manglende samarbeid på tvers og silotenkning i det offentlige som en utfordring. Dette er også noe som fremkommer $i$ andre sammenhenger.

\section{Forslag}

- Nasjonale myndigheter oppfordres til å adressere feltet på et mer tverrdepartementalt og strategisk plan.

Et aktuelt tema i et tverrdepartementalt samarbeid er erfaringer med og utfordringer knyttet til et konkurranseutsatt marked og anskaffelsesregelverk. Anskaffelsesregelverket oppleves som et hinder for sosialt entreprenørskap og sosial innovasjon av respondenter i alle land. Blant aktuelle spørsmål er i hvilken grad er utfordringene knyttet til selve regelverket eller praktiseringen av det? Hvilket handlingsrom gir eksisterende regelverk?

Et annet aktuelt tema er erfaringer og utfordringer knyttet til ulike finansieringsløsninger og andre støttestrukturer (i ulike sektorer) og behov for endringer. Manglende finansieringsløsninger og støttestrukturer tilpasset området er også hindre som nevnes av respondenter i alle 
land. Blant aktuelle spørsmål er: I hvilken grad legges det til rette for sosialt entreprenørskap gjennom mer generell innsats for entreprenørskap og innovasjon? Hvilke forskjeller er det i behov og forutsetninger mellom sosiale entreprenører og andre entreprenører, og hva innebærer det av behov for særskilte løsninger for sosiale entreprenører?

\subsection{Sosialt entreprenørskap og sosial innovasjon som tema i yrkesutdanningene}

Sosialt entreprenørskap, sosial innovasjon, sosialøkonomiske virksomheter og sosiale foretak berører mange samfunnsområder og dermed ulike yrkesgrupper i økende grad. I dag speiles dette ikke i utdanningsplaner, kurslitteratur etc. Eksempler er utdanning for bedriftsøkonomer, samfunnsøkonomer, sosionomer, arbeidsformidlere, yrkesveiledere, samfunnsplanleggere.

Sosialt entreprenørskap handler om å utvikle løsninger på komplekse problemer som går på tvers av sektorer og fagfelt. En av fordelene ved sosialt entreprenørskap er at man i denne prosessen arbeider tverrsektorielt. Introduksjon av sosialt entreprenørskap som tema i utdannelsesplaner, kurslitteratur mv. kan bidra til økt fokus og forståelse av entreprenørskap og ulike forretningsmodeller i utdanninger på bolig- og sosialområdet, men også på løsning av samfunnsmessige problemer i merkantile og næringslivsrettede uddanninger.

\section{Forslag}

- Nasjonale myndigheter oppfordres til å vurdere behovet for utvikling av dette området. 
Del 2

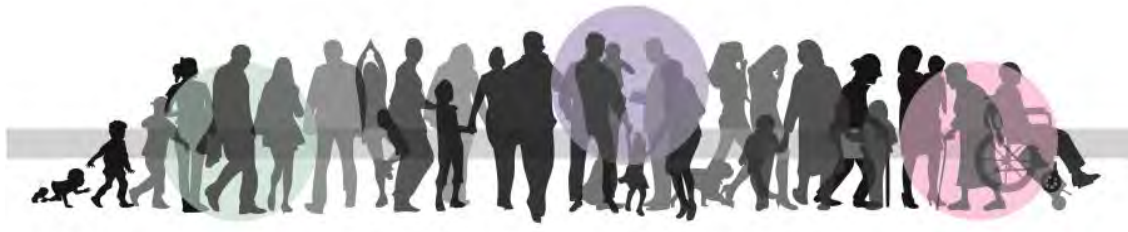





\title{
绪
}

\section{Sosialt entreprenørskap og sosial innovasjon ${ }^{3}$}

\author{
Lars Hulgård \& Linda Lundgaard Andersen
}

Sosialt entreprenørskap og sosial innovasjon har for alvor gjort sitt inntog på den internasjonale politiske arena som en sektor for produksjon av velferdtjenester kombinert med sterke og ofte motstridende verdier med hensyn til samfunnsnytte, markedsverdi, franchising, medinnflytelse og frivillighet. I det hittil største internasjonale verket om sosialt entreprenørskap (Kickul, Gras, Bacq \& Griffith, 2013) blir det påpekt at den første publikasjonen om sosialt entreprenørskap kom ut i 1991, mens det mellom 1991 og 1996 bare ble utgitt seks publikasjoner om emnet på verdensbasis. Frem til slutten av 1990-årene var sosialt entreprenørskap hovedsakelig et fenomen som vakte interesse blant praktikere og konsulenter, som i likhet med Douglas Henton og hans kolleger fra "Collaborative Economics" i Silicon Valley begynte å oppfatte seg selv som sivile og sosiale entreprenører som jobbet for å skape arenaer for samarbeid mellom næringslivsfolk, embetsmenn og ledere fra det sivile samfunn med det formål å skape lokal bærekraft (Leadbeater, 1996; Henton et al., 1997; Hulgård, 2007).

Deretter ble det fart i sakene. Allerede i 2006 viste en oversikt at aktiviteter som kan karakteriseres som sosialt entreprenørskap, foregår hyppigere enn andre former for entreprenørskap. Fenomenet ble fulgt opp på forsknings- og utdanningssiden i form av en betydelig økt publiseringsvirksomhet (Steyart and Hjorth, 2006). Sosialt entreprenørskap er fortsatt et lite utviklet forskningsfelt og sterkt preget av at noen av de viktigste referansene på området er skrevet av journalister (Bornstein, 2004) og konsulenter (Leadbeater, 1996; Mawson, 2008; Elkington \& Hartigan, 2008), mens de tidligste forskningspublikasjonene på området var kortfattede og sporadiske (Dees, 1998; Austin et al., 2003). De senere årene har det imidlertid begynt å komme forskning på området, som 
belyser sosialt entreprenørskap som begrep og sammenligner det med andre typer entreprenørskap (Steyart \& Hjorth, 2006; Mair, 2006; Hulgård, 2007; Light, 2008; Nicholls, 2008; Andersen, Bager \& Hulgård, 2010; Fayolle \& Matlay, 2010; Defourny, 2010; Hulgård og Andersen, 2012, Kickul et al, 2013). Først nylig har det begynt å komme forskning som belyser de spesielle egenskapene som preger sosialt entreprenørskap og sosial innovasjon i Norden og de nordiske landene (Pestoff, 2009; Levander, 2012; Hulgård og Andersen, 2012; Rosenberg, 2013; Fæster, 2013). De nordiske statenes spesielle egenskaper tatt i betraktning, mangler det fortsatt grundige analyser, særlig av samspillet mellom sosialt entreprenørskap, offentlig sektor og den tredje sektor. Sannsynligvis har dette samspillet nemlig fungert som en viktig fødselshjelper for nyere og omfattende eksempler på sosialt entreprenørskap.

Sosialt entreprenørskap (SE) og sosial innovasjon (SI) er blitt sterke metaforer for en ny form for verdidannelse og løsningsmodell som verden har et skrikende behov for. I kjølvannet av finanskrisen har nobelprisvinner i økonomi, professor Joseph Stiglitz, påpekt at sosial innovasjon er like viktig som teknisk innovasjon når det gjelder å utvikle bærekraftige økonomiske institusjoner. Det danske konsulenthuset Mandag Morgen har dessuten beskrevet hvordan de europeiske sosiale servicemodellene befinner seg på en brennende plattform av trender som er innbyrdes motstridende og at det derfor foreligger et stort behov for å utvikle sosialøkonomiske institusjoner og andre former for sosial innovasjon. Befolkningene blir eldre, noe som gir et økende behov for sosiale tjenester. Imidlertid er de offentlige budsjettene presset. Befolkningene blir mer forskjelligartede og har forskjellige preferanser når det gjelder "det gode liv". Også dette setter de offentlige budsjettene under press. Disse trendene er pakket inn i en ytre ramme av økende kulturelt mangfold, større ulikhet og fragmentering av beslutningsprosesser. Både sosialt entreprenørskap og sosial innovasjon fremheves ofte som tiltak som kan demme opp for de negative konsekvensene av disse utviklingstrendene (BEPA, 2010). Alle hjørner av samfunnet er derfor viktige i forbindelse med utvikling av nye og sosialt innovative modeller: Private virksomheter blir oppfordret til å ta sitt sosiale ansvar alvorlig. Stat og kommune oppfordres til samarbeid med sosiale aktører for å bli mer innovative i måten å håndtere sine oppgaver på. Og endelig appelleres det til sivilsamfunnet, ettersom det ofte er her vi kan finne sosiale entreprenører som iverksetter sosiale innovasjoner i form av nye tiltak og sosial virksomhet.

Denne delen av den nordiske rapporten bygger på vår forskning og vårt arbeid på det sosialøkonomiske feltet gjennom en årrekke. Vi har 
ikke gjennomført ny forskning i forbindelse med arbeidet i den nordiske arbeidsgruppen. Derfor er delrapporten for det første en innføring i allerede tilgjengelig forskningsbasert kunnskap om SE-feltet, deriblant både sosialt entreprenørskap og sosialøkonomisk virksomhet (social enterprise). For det andre har vi fors $ø$ kt å sette hele SE-feltet inn i en kontekst som omfatter de nordiske velferdsstatene. Dette er en vanskelig oppgave, fordi det ikke har vært gjennomført en komparativ undersøkelse av sosialt entreprenørskap på nordisk nivå. Det har heller ikke vært gjennomført omfattende forskning på området i de enkelte nordiske landene. I stedet for å yte hvert enkelt land rettferdighet gjennom en detaljert gjennomgang av den utvikling som har skjedd på feltet, har vi brukt eksempler fra Norden generelt og fra de enkelte land når vi har funnet det relevant. Dermed er ingen av de nordiske landene behandlet helt rettferdig, ettersom sosialt entreprenørskap og sosial innovasjon har utspilt seg på mange forskjellige måter. Vi har imidlertid ikke grunnlag for en detaljert gjennomgang eller håndfaste konklusjoner. Ikke desto mindre håper vi at delrapporten kan bidra til å finne ut om det finnes noe spesifikt nordisk på området sosialt entreprenørskap og sosial innovasjon.

\subsection{Definisjon på sosialt entreprenørskap og sosial innovasjon}

Vi definerer sosialt entreprenørskap som det å skape sosial verdi gjennom innovasjon, med en høy grad av deltakerorientering, ofte med deltakelse av det sivile samfunn og ofte med en økonomisk betydning. Ofte skjer innovasjonen på tvers av de tre sektorene stat, marked og sivilsamfunn, noe som kanskje særlig gjelder for Norden. Vi kommer tilbake til det spesifikt nordiske i avsnitt 3 og 4 i dette kapittelet. Definisjonen bygger på de siste 20 årenes viktigste forskning innen sosialt entreprenørskap. Forskere ved Harvard Business School har temmelig kritisk fremhevet ulikhetene mellom kommersielt og sosialt entreprenørskap i den hensikt å poengtere det som særpreger sistnevnte spesielt. Mens hovedmotivet for entreprenører på det kommersielle kapitalmarkedet er å bygge opp en lønnsom virksomhet som kaster godt av seg, er drivkraften for sosiale entreprenører "å skape en sosial verdi" (Austin, Howard \& Skillern, 2003). Forskerne fra Harvard påpeker her at til tross for muligheten til å operere med mange bunnlinjer på det "kommersielle kapitalmarkedet”, er det, når alt kommer til alt, den økonomiske bunnlinjen som teller, mens det for sosiale entreprenører er den sosiale bunnlinjen. Gregory Dees er en annen viktig forsker på området sosialt entreprenør- 
skap. Sammen med kolleger har han definert sosialt entreprenørskap som en metode for å "finne nye og bedre måter å skape sosial verdi på" (Dees, Emerson \& Economy, 2002). Endelig har Alex Nicholls ved Oxford University definert sosialt entreprenørskap som:

kombinasjonen av et overordnet sosialt kall og entreprenørorientert kreativitet (Nicholls, 2006).

Vi vil her påpeke tre viktige forhold knyttet til definisjonen på sosialt entreprenørskap.

For det første: Mens sosial verdi og innovasjon forekommer i de fleste definisjoner (Dees et al., 2002; Austin et al., 2006; Nicholls, 2006; Light, 2008), fremheves ord som "deltakelse", "sivilsamfunn" og "økonomisk betydning" ofte, men med forskjellig vekt. Deltakelse og sivilsamfunn er viktige kategorier, ettersom de markerer at sosialt entreprenørskap ikke bare dreier seg om å nå endelige sosiale mål, men også om prosessene og relasjonene som skaper de sosiale verdiene. Denne tilnærmingsmåten er i overensstemmelse med "state of the art" innen sosial innovasjonsteori, som nettopp fremhever sosial innovasjon som integrasjon av prosess og resultat (BEPA, 2010; Moulaert, Jessop, Hulgård \& Hamdouch, 2013). Det betyr at sosial innovasjon handler like mye om endring av de sosiale relasjonene som frembringer innovasjonen som selve produktet av innovasjonen (Moulaert, 2005). Videre er det en empirisk kjensgjerning at aktører fra det sivile samfunn er de mest populære partnerne i de fleste eksempler på sosialt entreprenørskap, enten i form av frivillige organisasjoner eller bekymrede og ansvarlige grupper av borgere som ønsker å utgjøre en forskjell (Andersen, Bager og Hulgård, 2010; Hulgård, 2007). Den økonomiske faktoren er viktig for å understreke selve entreprenøraspektet. Den klassiske entreprenørskapsteoretikeren Joseph Schumpeter påpekte at det ikke er selve invensjonen, eller oppfinnelsen, som kan karakteriseres som entreprenørskap. Det kan først den praktiske gjennomføringen. I dette ligger selve innovasjonen:

Economic leadership in particular must hence be distinguished from "invention" as long as they are not carried out into practice, inventions are economically irrelevant (Schumpeter, 1934: 66).

Det er den praktiske gjennomføringen som bærer innovasjonen i seg, og innovasjoner har ofte en økonomisk betydning, ikke bare i økonomisk entreprenørskap, men også i sosialt entreprenørskap. En økonomisk betydning for entreprenøren som påtar seg en risiko, og fremfor alt for deltakerne og de sosialt utsatte medborgerne som innovasjonen er ret- 
tet mot. Endelig er det en empirisk kjensgjerning at praktiske eksempler på sosialt entreprenørskap ofte er å finne på tvers av én eller flere sektorer (Nyssens, 2006). Videre har blant andre Kerlin (2009) vist hvordan sosialt entreprenørskap i USA gjerne foregår som et samarbeid mellom aktører fra det sivile samfunn og private virksomheter, mens tilsvarende aktiviteter i Europa ofte innebærer et samarbeid mellom offentlig sektor og det sivile samfunn og til en viss grad også i tilknytning til virksomhetenes praktisering av Corporate Social Responsibility (CSR). På globalt plan virker det som om sivilsamfunnet er den konstante part i sosialt entreprenørskap, mens det skiftes partner alt etter region og lokal institusjonell sammenheng.

For det andre: Sosialt entreprenørskap relaterer seg til sosial innovasjon, men de to fenomenene er ikke det samme. Dette kan illustreres på flere måter. Den enkleste er å gjøre som Schumpeter, nemlig å påpeke at det er entreprenøren som iverksetter innovasjonen. Uten entreprenørens aktive innsats for å omsette ideen i praksis, ville det "bare" være snakk om en invensjon eller oppfinnelse. På denne måten er sosialt entreprenørskap alltid knyttet til praksis: Sosiale entreprenører skaper sosiale innovasjoner, som ellers "bare" ville vært ideer til bedre måter å løse sosiale problemer og utfordringer på. Dette er imidlertid en noe forenklet eller reduksjonistisk måte å se tingene på. Blant forskere innen sosial innovasjon er det viktig å fremheve forbindelsen til sosiale bevegelser og innovative sosiale prosesser som ikke dreier seg om virksomhetsøkonomi. Tvert imot kritiseres aktuelle drøftinger av "sosialt entreprenørskap" og "social enterprise" for å overskygge "sosial innovasjon" med "en snever markedsøkonomisk terminologi" (Jessop, Moulaert, Hulgård \& Hamdouch, 2013: 110). Slik påpeker den mer kritiske forskningen innen sosial innovasjon at det har oppstått et brudd mellom de klassiske samfunnsvitenskapelige endringsteorier, som også tok for seg sosial innovasjon, og de nye sosiale innovasjonsanalyser hvor markedsøkonomien utgjør en viktig ramme for å forstå fenomenet og hvor "sosiale entreprenører" og "social enterprises" er hovedverktøyet til å skape sosial innovasjon. En slik reduksjon er problematisk, fordi den både ignorerer sosiale bevegelsers avgjørende rolle gjennom historien når det gjelder å skape sosial endring og i nyere tid velferdsstatens avgjørende betydning når det gjelder å skape sosiale megainnovasjoner i form av omfattende, brobyggende sosial kapital gjennom fenomener som byplanlegging, sykehusvesen, daginstitusjoner, omfordeling, folkeskole, pleie og omsorg samt andre typer aktivt sosialt og politisk medborgerskap.

For det tredje: Sosialt entreprenørskap og sosialøkonomisk virksomhet (social enterprise) er beslektet, men ikke det samme. Dette kan illustreres med tre observasjoner. Observasjon nummer én: I sin bok om 
hvordan sosialøkonomisk virksomhet kan bidra til å redusere fattigdom, hevder Muhammad Yunus at mens sosialt entreprenørskap er en omfattende idé om å skape innovative tiltak som kan hjelpe folk i nød, handler sosial virksomhet om å gjøre det med virksomhetsøkonomiske midler (Yunus, 2007: 32). Observasjon nummer to: Gregory Dees og hans kolleger har påpekt at "sosialt entreprenørskap handler ikke om å starte virksomhet eller bli mer kommersiell, men om å finne nye og bedre måter å skape sosial verdi på” (Dees, Emerson \& Economy, 2002). Her ser vi at sosialt entreprenørskap handler om sosial endring og dermed er nært knyttet til klassisk sosial innovasjon. Kanskje er den beste måten å skape sosial endring på å engasjere seg i sosiale bevegelser og nye interesseorganisasjoner, kanskje er det å skape sosialøkonomisk virksomhet eller kanskje å opprette nye statlige velferdsprogrammer. Alle tre eksempler kan være like relevante uttrykk for sosialt entreprenørskap, ettersom det er sosial verdi som står i sentrum! Den tredje og siste observasjonen er knyttet til EMES-nettverket, en europeisk forskningsorganisasjon som jobber med alle tre former for SE og SI: "social enterprise", "sosialt entreprenørskap" og "sosial innovasjon". EMES-nettverket ble dannet da europeiske forskere midt på 1990-tallet studerte en bevegelse der særlig sivilsamfunnsorganisasjoner begynte å bli mer markedsorientert (Defourny, 2001). EMES' forskning har senere dokumentert hvordan sosialøkonomiske virksomheter (social enterprise) har tre kjennetegn, nemlig økonomiske, sosiale og ledelsesrelaterte (governance). Det er sammenfallet av disse tre kjennetegnene som skiller "social enterprise" fra andre beslektede fenomener. Det som skiller sosialøkonomiske virksomheter fra frivillige organisasjoner, vil altså ofte være de økonomiske aspektene. Det vil si at det dreier seg om en virksomhet som dels har ansatte (og ikke bare frivillige) og dels er underlagt risikovilkår.

Som det fremgår ovenfor, finnes det mange typer entreprenørskap som ikke er knyttet til teknologisk eller kommersiell innovasjon og entreprenørskap. Ettersom flere av disse kan være relevante for en nordisk strategi på området, vil vi gjennomgå dem kort her.

\subsubsection{Mange former for sosialt, politisk, moralsk og sivilt entreprenørskap}

Sosialt entreprenørskap representerer et av flere trinn i forståelsen av entreprenørskap og innovasjon, fra i utgangspunktet å hentyde til økonomiske endringsagenter (Schumpeter, 1934) til også å omfatte offentlige entreprenører (Ostrom, 1965), moralske entreprenører (Becker, 1963; Hunter \& Fessenden, 1994) og sivile entreprenører (Henton et. al 
1997). Der den moralske entreprenøren er opptatt av å skape nye, forpliktende moralske standarder (kampen for et røykfritt offentlig rom trekkes ofte frem som et resultat av moralske entreprenørers innsats), er de offentlige og sosiale entreprenørene opptatt av å skape forpliktende innovasjoner som gir større lokal og sosial handlekraft (Ostrom, 1965; Svendsen \& Svendsen, 2004). Men hvem er så de sosiale entreprenørene og hvilken rolle spiller de i innovasjonen av velferdssamfunnets private og offentlige institusjoner.

\subsubsection{Både offentlige og sosiale entreprenører er opptatt av å produsere bærekraftige og kollektive goder gjennom innovasjon og samarbeid}

Allerede i sin avhandling fra 1965 stilte Elinor Ostrom, som i 2009 ble den første og hittil eneste kvinne som har mottatt den prestisjefylte nobelprisen i økonomi, spørsmålet om det finnes en parallell til entreprenørskap i den private sektor blant aktører som "frembringer offentlige goder og serviceytelser i den offentlige sektor", en funksjon som i gitte tilfeller kan betegnes som "offentlig entreprenørskap" (Ostrom, 1965: 24). I sin avhandling la Ostrom vekt på at offentlige entrepren ører realiserer en visjon om å samle produksjonsfaktorene gjennom kollektive handlinger med tanke på å skape offentlige goder og serviceytelser. Det var nettopp forståelsen av borgernes roller som innovatører og entreprenører som var Nobelkomiteens begrunnelse for å velge Ostrom i 2009. Hennes forskning på hvordan alminnelige borgere blir offentlige entreprenører er det som gjør henne til en sentral figur også i utviklingen av forskningsbasert kunnskap om sosialt entreprenørskap, som ellers lider under manglende systematisk teoretisk og empirisk forskning. Ostrom er for øvrig et godt eksempel på at sosialt og offentlig entreprenørskap inntil relativt nylig har vært et underbelyst fenomen både i sosiologi og politologi. For eksempel finnes det ikke en eneste referanse til Elinor Ostrom i det meget omfattende og ensyklopedisk oppbygde danske verket "Klassisk og moderne politisk teori" (Kaspersen og Loftager, 2009). Det er således interessant at politisk eller offentlig entreprenørskap (offentlig innovasjon) helt frem til 2009 ikke var anerkjent som et viktig element i moderne politisk teori. Gjennom Ostroms forskning er det dokumentert at borgergruppers og foreningers forvaltning av felles goder ofte gir langt bedre resultater enn de som gjerne presenteres i økonomisk teori. Ostroms analyser av kollektive handlingers betydning for utvikling og styring av goder er dessuten et alternativ til synspunktet om at mennesker alltid fors øker 
å oppnå maksimal nytte for seg selv, fordi de som oftest er "interess erede i ganske snævre selviske mål" (Tullock, 1970: 33, sitert etter Nannestad 2009: 842) eller fordi målet er å oppnå individuell profitt (Schneider, Teske and Mintron, 1995). Slik representerer Ostroms forskning og øvrige kollektivt orienterte tilnærmingsmåter til offentlig og sosialt entreprenørskap kunnskap som kan vise seg avgjørende for å finne nye veier ut av den økonomiske og multidimensjonelle krisen.

Innen forskning på både offentlig og sosialt entreprenørskap ser vi en skillelinje mellom betydningen som tillegges enkeltindividet og kollektiver og organisasjoner. Der Schneider, Teske og Mintron påpeker at det er "årvåkne individer" motivert av muligheten for en "personlig gevinst" (Schneider et al., 1995: 56) som blir offentlige entreprenører, understreker Ostrom betydningen av kollektive handlinger. Vi ser den samme skillelinjen representert i sosialt entreprenørskap, hvor særlig amerikanske analyser (Dees, 1998; Dees et al., 2002) og interesseorganisasjoner som Ashoka og Skoll Foundation legger stor vekt på den individuelle entreprenør, mens europeiske forskere ofte har en kobling til opprettelsen av foreninger i den tredje sektor (Defourny, 2010) og til den historiske rollen sosialøkonomien har spilt i utviklingen av de europeiske velferdsstater (Pestoff, 2009).

\subsection{Sosialt entreprenørskap mellom stat, marked og sivilsamfunn}

I de nordiske landene er sosialt entreprenørskap og sosial innovasjon kanskje i særlig grad nært knyttet til et dynamisk samspill mellom tre bærebjelker i det moderne samfunn: Stat, marked og sivilsamfunn. Dette fremgår av figur 3.1. 
Figur 3.1. Sosialt entreprenørskap i et kryssende felt av sektorer

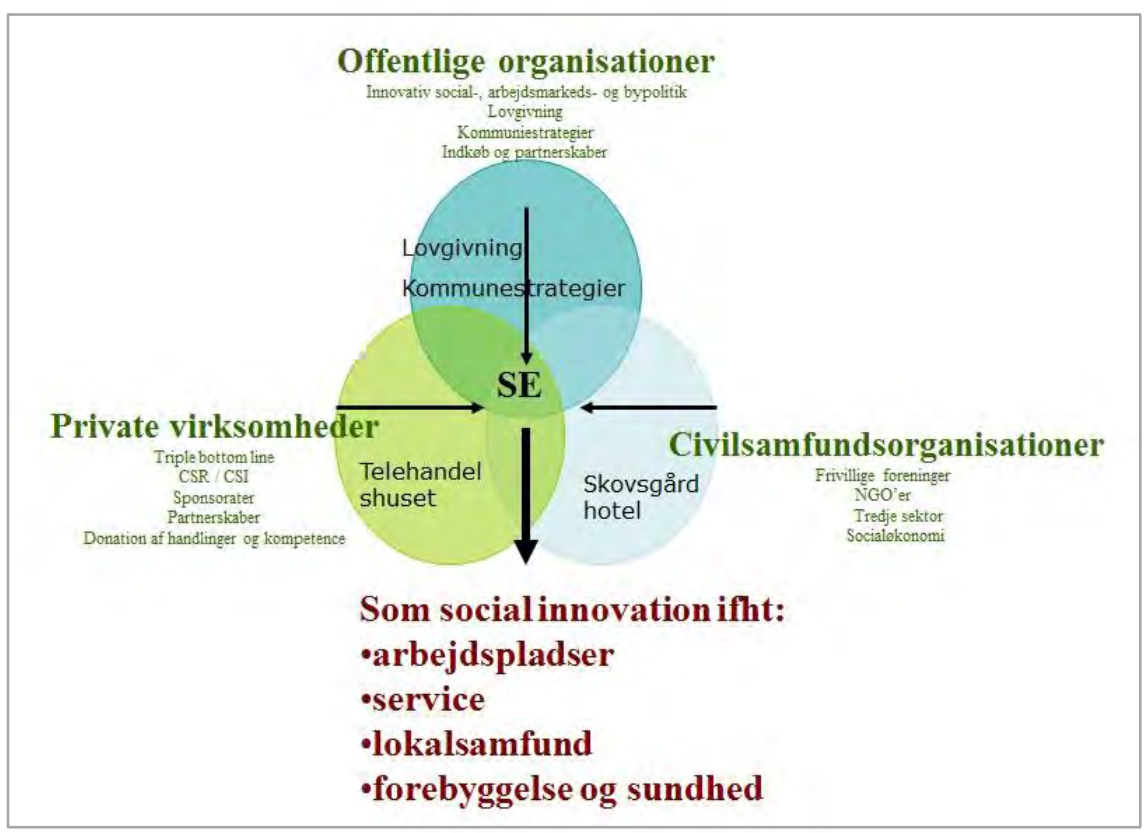

Figuren viser hvordan sosialt entreprenørskap i Europa generelt, men kanskje i Norden spesielt, kan forstås som en konsekvens av en rekke bevegelser som har skjedd innenfor og mellom de tre sektorene som utgjør det moderne samfunn. Figuren viser også et fenomen som ble registrert av den tyske velferdsforskeren Adalbert Evers, nemlig det faktum at entreprenørskap og innovativ tenkning er nødvendig $\mathrm{i}$ alle typer organisasjoner i dag, uavhengig av hvilken sektor de tilhører (Evers, 2001). Poenget er at sosialt entreprenørskap som aktivitet bryter opp grensene som analytiske debatter og utallige eksperter har skapt gjennom årene. Det dreier seg om grensen mellom "action for private benefit and action for the public good" (Evers, 2001: 296). Sosialt entreprenørskap og sosiale virksomheter utfordrer den tradisjonelle kunnskapen vi har om de tre sektorene og samspillet dem imellom. Som vi vil se i avsnitt 3.3. i dette kapittelet, angriper slike hybride aktivitets- og organisasjonsformer tidligere tiders strenge inndelinger og tillater seg å verdisette det sivile samfunn på en ny måte. La oss kort belyse de tre sektorenes bidrag til sosialt entreprenørskap.

Offentlige organisasjoner og den offentlige sektor generelt har siden begynnelsen av 1980-tallet gjennomgått en drastisk endring i retning av omstilling, overgang til nettverksstyring og nye former for desentralisering hvor det offentlige finner nye måter å samarbeide om etablering av nye velferdsløsninger på med aktører fra de øvrige sektorene. Noen peilemerker for denne prosessen er de omfattende forsøksprogramme- 
ne som både på europeisk nivå og i de nordiske landene skapte en mer eksperimenterende måte å håndtere områder som sosialt arbeid, byutvikling, kultur- og helsepolitikk på. Mange av organisasjonene som i dag er kjent som sosialøkonomiske virksomheter, blant annet i Danmark, har sin opprinnelse i slike nasjonale og europeiske forsøksprogrammer. Et annet peilemerke er de mange moderniseringsprogrammene som ble innført på 1980-, 1990-tallet og fremover, som har til formål å regulere og utvikle den offentlige sektoren i retning konkurransestaten gjennom effektivisering, konkurranse, ledelsesutvikling og utviklingsarbeid. Denne utviklingen er samtidig et eksempel på at de nordiske landene kjennetegnes av innovativt orienterte velferdsstater som inntar en sentral posisjon i utviklingen av de ulike typene sosialt entreprenørskap og sosial innovasjon. Velferdsstaten bidrar aktivt til å igangsette og utvikle sosial innovasjon og sosialt entreprenørskap, og overlater ikke bare dette til frie markedskrefter og entreprenørvillige samfunnsborgere. Men samtidig er det viktig å tenke på i hvilken grad det samme velferdssystemet også fungerer som en hemmende faktor. Sammenlignet med andre europeiske land - kanskje særlig England og Italia - kan det virke som om mer minimalistiske typer velferd skaper et utgangspunkt hvor sosiale entreprenører så å si arbeider i et vekstlag av udekkede sosiale og samfunnsmessige behov som håndteres gjennom utvikling og levering av nødvendige velferdstjenester (se også Lundgaard Andersen, Hulgård og Bisballe, 2008).

Private virksomheter har betydning for utvikling av sosialt entreprenørskap og sosial ansvarlighet. Individuelle kommersielle entreprenører og virksomheter har ofte stilt opp for filantropiske og veldedige formål i større og mindre skala, og private virksomheters sponsorvirksomhet er et kjent fenomen på området idrett og kultur. Corporate Social Responsibility, CSR,eller det at virksomheter viser sosialt ansvar, er derfor ikke noe nytt. Det nye er derimot at det er mye snakk om CSR og at mange private virksomheter aktivt innlemmer CSR i forretningsutvikling og kjerneområder, og formidler dette flittig og kreativt til interessenter og kunder. CSR utøves på mange måter. På den ene side hersker det neppe tvil om at private virksomheter i stadig større grad måles etter sine bidrag til sosial og miljømessig bærekraft og etter hvorvidt de klarer å skifte fokus fra kortsiktig lønnsomhetstenkning til langsiktige, verdibaserte relasjoner i samarbeid med lokale interessenter. På den annen side er det igjen verdt å minne om forskjellen som ble beskrevet av Harvard-professoren James Austin, en av verdens dyktigste forskere innen entreprenørskap: 
På det kommersielle kapitalmarkedet er hovedmotivasjonen for alle involverte å bygge opp en lønnsom virksomhet og oppnå god gevinst på investeringene. Den underliggende motivasjonen i sosialt entreprenørskap er å skape sosial verdi fremfor personlig verdi eller verdi for aksjonærene (Austin et.al., 2003: 2).

Med den omfattende privatiseringen som også har foregått i de nordiske landene og i kjølvannet av finanskrisen, er det interessant å observere private virksomheters sosiale engasjement og omstilling til bærekraftig drift.

Sivilsamfunnet og organisasjoner $i$ det sivile samfunn oppfattes av mange eksperter som den største bidragsyteren til sosialt entreprenørskap. Alex Nicholls, som var med på å starte Skoll Centre for Social Entrepreneurship ved Oxford Saïd Business School, har påpekt at det sivile samfunn er det sosiale entreprenørskapets "grunnfjell" (bedrock). Andre har lagt vekt på at sosialt entreprenørskap og sosiale virksomheter har røtter i den kooperative sektoren, som historisk sett var en viktig del av sivilsamfunnet (Gawell, 2008: 8). Det sivile samfunn består av et mangfold av organisasjonsformer og interesser. Janoski (1998) har imidlertid påpekt at alle har det til felles at de kan omgjøre private bekymringer og problemer til offentlige eller kollektive spørsmål og problemstillinger. Det sivile samfunn bidrar altså ofte til å forvandle enkeltindividets sårbarhet (psykisk, helsemessig eller i forhold til arbeidsmarkedet) til en utfordring som kan håndteres i fellesskap, blant annet i sosialøkonomiske virksomheter. For sivilsamfunnsorganisasjoner kan innovasjonspresset og kravet om å utarbeide markedsstrategier gjøre at de føler seg tynget av krav om ytelse, produksjonsmål og evidensbasert dokumentasjon. Samtidig gir det organisasjonene mulighet til å jobbe med innovasjon og entreprenørskap gjennom håndfast dokumentasjon og dermed kunne eksperimentere med sitt ressursgrunnlag og utvide porteføljen av aktiviteter. Kravet til dokumentasjon og beviser kan dermed fungere på to måter. Det kan både sette frivillige foreninger på det sosiale området under press for å bli profesjonelt drevne, markedsorienterte organisasjoner (isomorfi) og det kan gi foreningene gode argumenter på hånden overfor eksterne samarbeidspartnere om at nettopp de har stor gjennomslagskraft $i$ kraft av sin lokale og frivillige forankring.

Nedenfor skal vi først se hvordan forskning fra Sverige, Norge og Danmark peker på rimelig ensartede resultater med hensyn til de nære relasjonene mellom den nordiske velferdsstaten og det sivile samfunn (Rothstein, 2001; Selle, 1999; Torpe, 2001; Kritmundsson \& Hrafnsdóttir, 2012)). Deretter vil vi drøfte om den nære forbindelsen mellom det offentlige og sivile samfunn er blitt utfordret av de senere års priva- 
tisering og markedsorientering og dermed har skapt nye rammer for sosialt entreprenørskap og sosial innovasjon i de nordiske landene (Pestoff, 1999; Wijkström, 2011, Hulgård \& Andersen, 2012).

For det første viser Rothstein (2001) at utbyggingen av velferdsstaten i tiårene rett etter andre verdenskrig var basert på:

an unusually close collaboration between the state and major interest organizations in the preparation as well as in the implementation of public policies ... (Rothstein, 2001: 207).

The "universal welfare state did not wipe out" social capital, and the results from two studies show that people in the 1990s were generally more interested in socializing than they were in the 1950 s before the expansion of the welfare state (Rothstein, 2001: 224).

Men allerede i de siste tiårene av det 20. århundret har det ifølge forskere som Rothstein (2001) og Selle (1999) skjedd en endring i sammensetningen av det sivile samfunn, i form av en prosess i retning av "organized individualism" (Rothstein, 2001: 220). Denne endringen i retning av individualisering er sannsynligvis ytterligere forsterket gjennom økt bruk av markedsmekanismer i reguleringen av sivilsamfunnet. På den måten er de tette historiske båndene mellom sivilsamfunn og offentlig sektor i de nordiske land kanskje i ferd med å endre karakter. Wijkström (2011) har i den sammenheng påpekt at mens den typiske hybride karakteren til sivilsamfunnet i det 20. århundret kunne beskrives som "half movement" og "half government", har relasjonen i dag fătt et nytt preg av "half charity" og "half business", som retter seg mer mot entreprenørskap og forretning. Denne utviklingstrenden har skjedd helt i overensstemmelse med tendensen til privatisering av velferdsstaten som forskere har registrert, hvor utviklingen har gått fra:

en idealtypisk skandinavisk velferdsmodell til en anglo-amerikansk modell ... med en felles kjerne av markedsorientert sosialpolitikk (Gilbert, 2002: 4, 182).

Sosialt entreprenørskap utøves altså mellom sterkt individualiserende og sterkt kollektiviserende dynamikker med rot i de siste 30 årenes utvikling på velferdsområdet, så vel nasjonalt som internasjonalt.

De umiddelbare slagordene som preger den nye debatten om SE og SI i Norden, stammer fra internasjonale kilder (dette vil vi utdype i avsnitt 3.1. i dette kapittelet). Likevel finner vi en tydelig historisk parallell i de nordiske landene, som både kan spores tilbake til den gamle sosialøkonomien i form av andelsbevegelse og kooperativ virksomhet og i nyere tid til den sosialpolitiske og regionalpolitiske forsøks- og utviklingstradisjonen som 
så sterkt preget viktige velferdsområder som sosiale tjenester, landutvikling, integrering av etniske minoriteter, integrering på arbeidsmarkedet, livslang læring og utvikling av lokale kulturinstitusjoner fra midten av 1980-tallet og frem til midten av 1990-tallet.

Det hersker ingen tvil om at sosialt entreprenørskap står sentralt i den nordiske debatten om velferdsstatens fremtid. Det opprettes stadig interesseorganisasjoner og tas politiske og praktiske initiativ fra sosiale entreprenørers side. Internasjonalt vokser interesseorganisasjoner som Global Social Business Summit (Grameen Creative Lab), Ashoka, Skoll Foundation og Schwab Foundation i høyt tempo. På alle nivåer av den politiske arena utarbeides det strategier som skal oppmuntre sosiale entreprenører til å bidra i arbeidet med å løse problemet gjennom å levere og utvikle sosiale tjenester i en tid preget av et krysspress både som følge av demografiske endringer, økte forventninger og stadig større global konkurranse (BEPA, 2010). Aktivitetene som samlet sett kan kalles sosialt entreprenørskap, harmonerer godt med to store trender som har preget måten å betrakte velferd og sosiale tjenester på i dag. Den første kjennetegnes av markedsorientering og privatisering av det offentliges ansvar for velferd (Gilbert, 2002; Borzaga \& Santuari, 2003; Pestoff, 2009; Hulgård \& Andersen, 2012). Den andre tar utgangspunkt i både sosiale bevegelser og offentlige programmer som dreier seg om å eksperimentere med nye former for kollektivt ansvar, solidaritet og sivilsamfunnsbaserte innspill til den politiske utvikling (Hart, Laville og Cattani, 2010; Hulgård og Shajahan, 2012). Både i markedstrenden og i sivilsamfunnstrenden er sosialt entreprenørskap et aktuelt svar på de sosiale utfordringene som verden står overfor. Vi finner begge de nevnte trendene i Norden, men her er det snakk om to trender som aktivt bidrar til å realisere potensialet fra sosialt entreprenørskap på to vesensforskjellige måter.

På tvers av nasjonale forskjeller og typer velferdsregimer har det gjennom de siste 30 årene skjedd en global nyorientering av velferdsstatene i retning av økt privatisering og individualisering. Dette har medført en omstrukturering av den klassiske velferdsstaten slik den ble formet i kjølvannet av andre verdenskrig (Titmuss, 1977). Denne trenden har stor internasjonal gjennomslagskraft og danner nye rammer for velferdsstatlige fornyelsesprosesser. Gjennom empiriske analyser av utviklingen i den svenske velferdsstaten har Pestoff (2009) vist hvordan privatiseringen har fătt gjennomslag i "Folkehjemmet" fra 1980-tallet og fremover. Dette er vist i figur 3.2, som samtidig illustrerer at det finnes to veier fremover, hvor sosialt entreprenørskap og sosial innovasjon blir gjort til tema på to svært forskjellige måter. 
Figur 3.2. Development of the Swedish welfare state, ca. 1980-2030

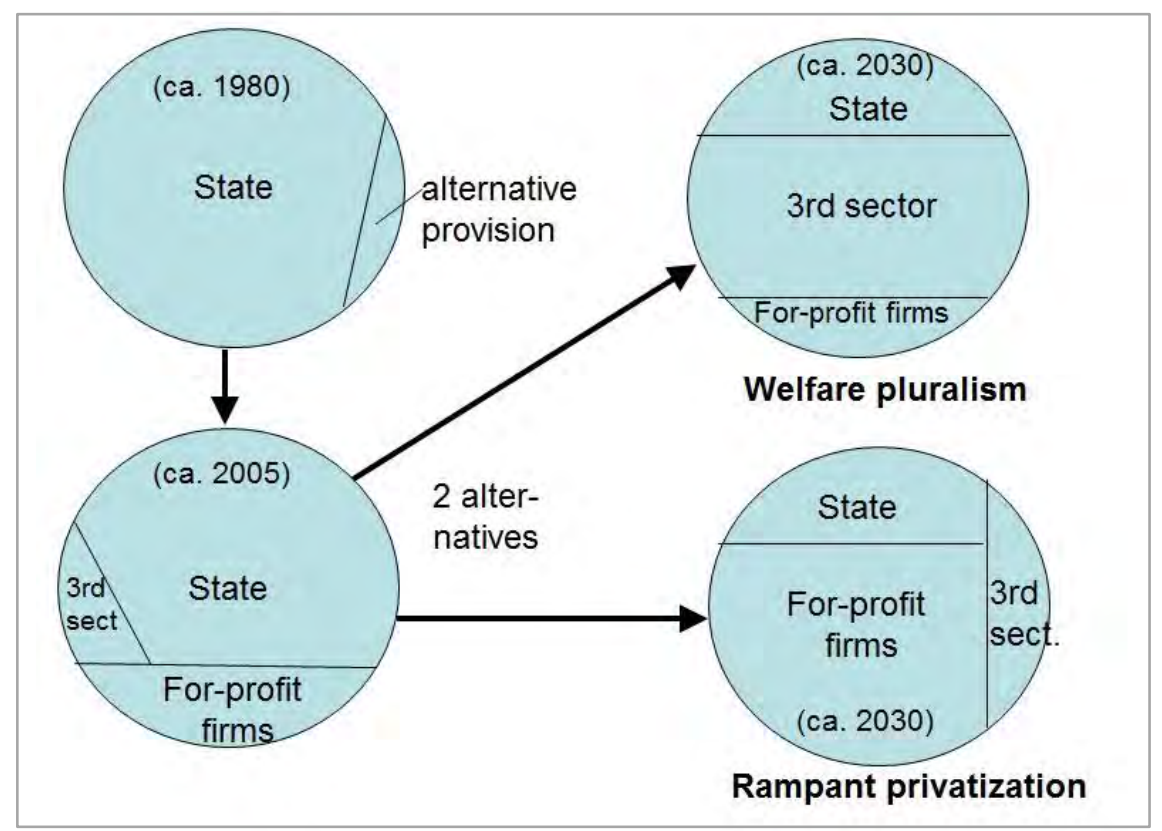

V. Pestoff: A Democratic Architecture for the Welfare State.

Som redskap til fornyelse av den sosiale innsatsen i velferdssamfunnet er sosialt entreprenørskap som skapt til å fylle rollen. Til tross for at utbyggingen av de moderne velferdsstatene startet tidlig i det 20 . århundret, var det først mot slutten av 1940-årene at politikere og eksperter begynte å se en utvikling i den universelle velferdsstatsrammen (Borzaga and Santuari, 2003: 36). Fra da av og frem til rundt 1970 var den politiske utvikling på velferdsområdet underbygget av visjonen om en mektig velferdsstat. Velferdsstaten var en helt sentral drivkraft for i det hele tatt å få det moderne samfunn til å fungere. Den universelle velferdsstaten var et aktivum i alle hjørner av høyhastighetssamfunnet som utviklet seg raskt i løpet av etterkrigsårene (Titmuss, 1987). Forskerne omtalte den universelt orienterte nordiske velferdsstaten som "den sosialdemokratiske modell" (Esping-Andersen, 1990), og i Sverige satt da også sosialdemokratene ved makten i 44 sammenhengende år fra 1932 til 1976. Og i 1976 attpåtil med statsminister Olof Palme, som våget å erklære at "The era of neo-capitalism is drawing to an end". Bakgrunnen for utsagnet er en epoke (1932-1988) hvor sosialdemokratene konstant hadde over $40 \%$ av stemmene. Men i tiden etter er det kanskje nettopp Sverige som har opplevd de raskeste endringene?

Fra 1970-tallet ser vi nemlig en gradvis endring i den sosialpolitiske orienteringen på internasjonalt plan: "De europeiske velferdssystemene 
begynner gradvis å smuldre opp" (Borzaga and Santuari, 2003: 38) under den økonomiske byrden, som samtidig varsler om store organisatoriske utfordringer med hensyn til å løfte det sosiale ansvaret. Den nye trenden i den velferdsstatlige orienteringen var å nedtone det offentliges ansvar for håndteringen av sosiale problemer. Dette fremgår tydelig i Pestoffs analyse av utviklingen i den svenske velferdsstaten (figur 2). Magasinet "The Economist" tok også for seg den nordiske utgaven av velferdsstaten i et temanummer i februar 2013, og noterte blant annet et drastisk fall i det offentliges andel av BNP:

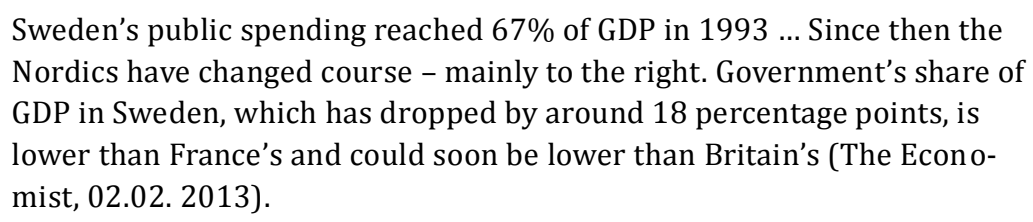

En kombinasjon av endringer i overordnede politiske maktforhold og økende misnøye med velferdsstaten fra både høyre og venstre la grunnlaget for endringer, deriblant den raske fremgangen for det nye høyres tilnærmingsmåte til velferd (Taylor, 2003: 3). Fra 1970-tallet og fremover begynte de moderne velferdsstatene å understreke individets ansvarlighet og medlemskap på bekostning av det offentliges ansvar, og dermed å følge en annen visjon enn den universelle og institusjonelle velferdsmodellen. Sosialpolitiske paradigmer som aktivering og selvhjelp får større gjennomslagskraft. Det samme gjør kombinasjonen av individuell ansvarlighet og medlemskap, noe som blant annet preger utviklingen på pensjonsområdet, hele det sykdomsforebyggende arbeidet og utviklingen på bolig- og aksjemarkedet. Disse områdene bidrar alle til en polarisering som ligger fjernt fra den universelle velferdsmodellen, som var bygd opp rundt en kjerne av universalisme og redistribusjon.

Endringen av velferdsstaten i retning av privatisering og medlemskap fremfor medborgerskap støtter ikke bare betydningen av individuell ansvarlighet. Den bidrar også til at sosial virksomhet og sosialt entreprenørskap lettere blir et møtested mellom innovative aktører fra de tre sektorene. Den økonomiske globaliseringen og endringene i velferdsstaten har imidlertid ikke bare medført mer individualisering og markedsorientering. Det har også bidratt til å danne en ny plattform for sivilsamfunn og nye former for kollektivt ansvar for utviklingen av velferdssamfunnet. $\mathrm{Vi}$ ser altså det paradoks at sosial virksomhet og sosialt entreprenørskap både kan være sentrale elementer i en privatiseringsstrategi og i en strategi som forsøker å utvide terrenget for sivilsamfunnet som et tredje samfunnsstrukturerende prinsipp basert på kollektivt ansvar og gjensidighet. 
Men hvordan skal vi så forstå de politiske forventningene og alle initiativene til sosialt entreprenørskap og hele SE-feltet som vi har sett utfolde seg i Norden og verden for øvrig? Er det et tegn på at sivilsamfunnet får stadig større innflytelse som en sfære for solidaritet og gjensidighet? Eller er det et tegn på at den private, tradisjonelle markedsøkonomien blir interessant for den tredje sektor som et springbrett til å utnytte markedet som ligger "nederst i pyramiden", den såkalte BoP? Ifølge de suksessrike lobbyistene på SE-området, Elkington og Hartigan, utgjør rundt fire milliarder lavinntektsforbrukere BoP (Bottom of the Pyramid). Og BoP venter bare på at fremgangrike sosiale entreprenører tar seg av disse:

market failures and bring much-needed benefits to poor people or, in the case of the more commercially minded, to make money in unlikely circumstances (Elkington \& Hartigan, 2008: 42).

Observasjonen av bevegelser og spenninger på SE-området er dessuten inspirert av internasjonale utviklingsdebatter knyttet til både sosialt arbeid (Desai, Monteiro \& Narayan, 1998; Ho \& Yen, 2010; Hulgård \& Shajahan, 2012) og et syn på sosial innovasjon som bygger på et sterkt prosessperspektiv (Moulaert et. al., 2012; Moulaert, Jessop, Hulgård og Hamdouch, 2012). Er sosialt entreprenørskap således hovedsakelig et uttrykk for effektiv og innovativ produksjon av sosiale tjenester på det eksisterende markeds premisser, eller omfatter det en utopisk horisont for utvikling av mer deltakende og inkluderende praksiser som knytter seg til sosiale bevegelser og muligheten for et mer bærekraftig og inkluderende samfunn? Det er ennå for tidlig å trekke en konklusjon med hensyn til hvordan de involverte aktørene i dette paradigmet vil utøve og utvikle sosialt entreprenørskap. Til det er de ulike aktivitetene for unge. Hvordan sosialt entreprenørskap vil utvikle seg i de nordiske landene, vil de nærmeste årene gi svar på - og det kan bli svært så interessant å følge utviklingen.

\subsection{Temaer og definisjoner med røtter i et nordisk perspektiv}

Skal vi tegne konturene av hvordan et nordisk perspektiv på sosialt entreprenørskap kan betraktes, kan vi som oppsummering si at det både tar utgangspunkt i og blir inspirert av internasjonale strømninger, men også av at forskere og praktikere plasserer sosialt entreprenørskap og sosial innovasjon i sine nasjonale, kulturelle og historiske kontekster. Nedenfor vil vi oppsummere og beskrive temaene og trendene vi kan observere gjennom fem temaer: 1. Historiske røtter og forskningshorisont, 2. Bidrag 
til definisjoner på sosialt entreprenørskap, 3. Samproduksjon og hybriditet i et nordisk perspektiv, 4. Eksperimentelle laboratorier i velferdstjenester for utsatte borgere og 5 . Rammer og incitamentsstrukturer.

\subsubsection{Historiske røtter og forskningshorisont}

I et nordisk perspektiv er de historiske røttene og en historisk ramme for å forstå sosialt entreprenørskap et markant trekk, som vi kan se i både forskning, begrepsforståelse og praksis.

Fra et dansk perspektiv påpeker Hulgård og Andersen at sosialt entreprenørskap representerer et interessant særtilfelle i den internasjonale trend.

Helt konkret har sosialt entreprenørskap nådd Danmark utenfra, dels via en europeisk sosialøkonomisk tradisjon, særlig fra land som Belgia, Frankrike og Italia, og dels via en mer markedskonform tilnærming til sosiale tjenester fra land som USA og Storbritannia. Mens de umiddelbare slagordene som preger den "nye" debatten, har kommet til Danmark fra disse internasjonale sammenhengene. Historisk sett stod Danmark veldig sterkt i den første sosialøkonomiske bølgen som strømmet over verden fra midten av 1800-tallet og fremover, med andelsbevegelse og utvikling av den kooperative bevegelsen. Den andre sosial$ø$ konomiske bølgen oppstod internasjonalt med utgangspunkt i den frivillige sektoren fra midten av 1980-tallet og fremover. Her opplevde Danmark en stor grad av prosjektorganisering på bekostning av organisasjons- og virksomhetsutvikling, mens landet kom litt tregere i gang med hensyn til den tredje sosialøkonomiske bølgen, hvor vekten ligger på utvikling av sammenhengende strategier og politikker (Hulgård og Andersen, 2009, p.5).

Vi finner tilsvarende bølger i de andre nordiske landene, deriblant moderniseringen av velferdsstaten som har pågått siden 1980-årene. Denne moderniseringen har foregått som en lang rekke konsentrerte programarbeider og kan blant annet forstås som en utvikling av de sosiale entreprenørdimensjonene i velferdstjenester og -organisering, hvor innføringen av "kvasi-markedsbaserte" velferdstjenester, egenforvaltning og styrket fokus på brukerinnflytelse var deler av moderniseringens fokusområder (Andersen, 2014).

Fra et svensk perspektiv peker Gawell, Johannesen \& Lundqvist på at "samhällsentreprenörskap" på slutten av 1970-tallet er blitt drøftet i svensk forskning, idet forskere innen virksomhetsøkonomi behandler fenomenet som en del av en økonomisk utviklingsstrategi hvor industriell forvandling var i ferd med å endre arbeids- og livsvilkårene for mange mennesker. Debatten fokuserte også på lokalsamfunnenes overlevelse og store virksomheters ansvar for utvikling av lokalsamfunnene. På den måten synliggjøres "samhällsentreprenörskap" som fenomen og 
begrep både i forskningsverdenen og den praktiske verden (Gawell, Johannesen \& Lundqvist, 2010:15). Selv om samfunnsentreprenørskap har stått sterkt i den svenske offentlighet, har det også vært andre viktige fokuspunkter. Medlemmer av den nordiske arbeidsgruppen har for eksempel påpekt at Sverige har gjennomlevd en periode på 30 år

"av arbetsintegrerande sociala företag (WISE), 30 år av uppbyggnad av det som idag är Coompanion, en nationell stödstruktur för kooperation och annat företagande inom den sociala ekonomin."

Dette fokuset på arbeidsmarkedsintegrasjon er det lett å overse hvis man utelukkende oppfatter den "svenske modellen" ut fra begrepet "samhällsentreprenörskap" og lokale utviklingstiltak.

Fra et finsk perspektiv påpeker Harri Kostilainen og Pekka Pättiniemi hvordan sosiale virksomheter er formet på bakgrunn av internasjonal forskning og praksis, med erfaringer spesielt fra Italia og deres A- og Bmodelldefinisjoner av sosiale kooperativer samt Englands reform for offentlige tjenester. Sosiale virksomheter kan identifiseres spesifikt gjennom to bestemte roller som "change agents" og "contract partners of public services". De skisserer et kort historisk perspektiv som for Finlands vedkommende viser at før utbyggingen og etableringen av velferdsstaten, spilte sosiale virksomheter og kooperative former en viktig og innovativ rolle i utviklingen av industri- og lokalsamfunnet (Kostilainen og Pättiniemi, 2014). Finland har altså en lang historie, hvor "medborgerskapsorganisasjonene" har spilt en rolle som produsenter av tjenester. Ifølge opplysninger fra den nordiske arbeidsgruppen har utviklingen av sosialøkonomiske virksomheter imidlertid vært beskjeden i Finland i de senere år, og på vikende front sammenlignet med vanlige private virksomheter.

Fra et norsk perspektiv peker en utredningsrapport på at sosialt entreprenørskap de senere årene har vært viet økt oppmerksomhet, gjennom opprettelse av organisasjoner, utgitt litteratur, etablert nettressurser, blogger, arenaer og nettverk der sosialentreprenører eksponeres.

Eksempler på dette er SE-piloten, et nettverk av sosialentreprenører og filantroper som i april 2012 ga ut et forslag til handlingsplan for sosial innovasjon og sosialt entreprenørskap i Norge (Schei og Dalen, 2012), samt den nylig utgitte handlingsplanen og boken "Vilje til endring - Sosialt entreprenørskap på norsk" av (Schei og Rønning, 2009) (Gustavsen og Kobro, 2012: 40). En tidligere norsk utredning bygger på intervjuer med 20 sosiale entreprenører og dokumentanalyser, og foreslår tre typologier: idéutvikleren, fagspesialisten og idealisten som kjennetegn på sosialt entreprenørskap og sosiale virksomheter (Utredning om sosialt entreprenørskap, 2011: 22). På forskningssiden er arbeidet i 
Norge fremdeles på et begynnerstadium, med få publiserende forskere: Dr. philos. Eline Synneva Lorentzen Ingstad fra Senter for entreprenørskap ved Universitetet i Oslo forsker på "the scaling of social entrepreneurship organizations and scaling strategies focusing on how different stakeholders contribute in the scaling process and key success factors in the scaling process in Norway. Unni Beate Sækkerseter fra Center for sosialt entreprenørskab, ved Roskilde Universitet gjennomfører et doktorgradsstudium av "peer group lending strategies" og hvordan det er mulig å skape sosio-økonomisk endring gjennom bruk av en bestemt modell - "the peer group lending model" - analysert i fem ulike mikro-finansprogrammer i henholdsvis Norge, USA og England.

Fra et islandsk perspektiv er sosialt entreprenørskap og sosial innovasjon i følge innspill fra den nordiske arbeidsgruppen relativt ukjent. I Island har Hrafnsdòttir og Kristmundsson (2012) vist at det er en lang historie hvor tredje sektor og medborgerorganisasjoner har spilt en rolle som produsenter av velferdstjenester, hvorav noen kan kategoriseres som sosial innovasjon. På forskningssiden er innsatsen lite utviklet. Det er kun en tidligere islandsk undersøkelse basert på intervjuer med fem sosiale entreprenører (Àrmannsdòttir, 2010). I Island er det et stigende antall forskningsprosjekter som handler om tredje sektor, men forskning på sosialt entreprenørskap savnes.

I den nordiske forskningen, særlig fra Danmark, Sverige og Finland, finnes det indikasjoner på at sosiale virksomheter og kooperativer har fungert som en viktig drivkraft for innovasjon i utviklingen av industri, landbruk og lokalsamfunn, men at etableringen og utbyggingen av velferdsstaten i en periode medfører en svekkelse av disse fenomenene, fordi det offentlige tar over disse oppgavene. Samtidig ser vi en ny bølge av interesse for sosialt entreprenørskap og sosiale virksomheter på 2000-tallet. Den er inspirert av utviklingen i Europa og USA, men også drevet frem av et behov for å utvikle den nordiske velferdsstaten gjennom nye samarbeidsformer og partnerskap med sivilsamfunnsorganisasjoner.

\subsubsection{Bidrag til utarbeiding av definisjon på sosialt entreprenørskap}

De nordiske bidrag til begrepsutviklingen av sosialt entreprenørskap fastsetter ulike dimensjoner og punkter. Lars Hulgård og Linda Lundgaard Andersen tar utgangspunkt i EMES' definisjoner på "social entrepreneurship and social enterprises" med vektlegging av "the creation of social value through innovation including civil society as priviliged partner initiatiating activities of economic significance". Her påpekes det at 
sosial verdiskapning og sosial innovasjon står sentralt, samt at sivilsamfunnsdelen og den økonomiske verdiskapningen er likestilte elementer (Andersen \& Hulgård, 2014 og 2010, Hulgård, 2007). Malin Gawell, Bengt Johannessen \& Ulf Lundqvist oputvikler begrepet "Samhällsentreprenørskap" som en "motivational, innovative and value creation - rooted in a historical Swedish tradition for local community development" (Gawell, Johannessen \& Lundqvist 2010:13). Med det ønsker de å understreke at sosialt entreprenørskap kan forstås som samfunnsmessig entreprenørskap og at "sosial" i denne forstand må oversettes og fastholdes på den måten. Elisabeth Sundin og Malin Tillmar snakker om:

the intertwinement of the social, commercial and public entrepreneurship and how entrepreneurship exists in all sectors - a fact which is often underestimated (Sundin og Tillmar, 2010).

Daniel Hjorth foreslår å utvikle begrepet "Public entrepreneurship", som han definerer slik:

to elaborate on social entrepreneurship as increasing the social capacity of society, rather than the performance capacity of management. To place the citizen rather than the consumer at the centre of our attention (Hjorth, 2010).

Hjorths bidrag er altså i tråd med de internasjonale trendene vi tidligere har omtalt som kampen mellom en markedsorientert kontra en sosial verdiskapning som innfallsvinkel til sosialt entreprenørskap.

\subsubsection{Samproduksjon og hybriditet i et nordisk perspektiv}

Et annet markant spor i de nordiske landenes utvikling av sosialt entreprenørskap og sosiale virksomheter retter seg mot forskningen innen - samt tilhørende praksis - samproduksjon og begrepet hybriditet. En av de største bidragsyterne, Victor Pestoff, har utviklet og berettiget dette på svensk grunnlag, blant annet gjennom en rekke analyser som belyser svenske erfaringer og praksiser - i samspill med andre internasjonale eksempler. På bakgrunn av typologier utviklet av Osborne \& McLaughlin (2004) defineres samproduksjon ved hjelp av tre potensielle manifestasjoner:

co-production, co-management and co-governance [...] All refer to a type of cooperation in which the third sector has a direct influence on the nature of the service (i.e.output). They define: Co-governance as an arrangement, in which the third sector participates in the planning and delivery of public services, Co-management as an arrangement, in which third sector organizations produce services in collaboration with the state; and Co-production as 
an arrangement where citizens produce their own services at least in part (Pestoff og Brandsen, 2009:8).

Forskerne påpeker at disse tre dimensjonene ikke gjensidig ekskluderer hverandre, men tvert imot kan finnes i ulike kombinasjoner. Pestoffs poeng blir særlig interessant $i$ et nordisk perspektiv, hvor velferdstradisjonen bygger på sterke demokratiske prinsipper:

\footnotetext{
the democratic implications of co-production for social enterprises should be noted: both the consumers and providers in social enterprises can become more involved in the provision of enduring social services, thereby transforming them into grass-roots democratic organizations. Co-production is a mix of activities that both public service agents and citizens contribute to the provision of public services. The former are involved as professionals or „regular producer", while „citizen production" is based on voluntary efforts by individuals or groups to enhance the quality and/or quantity of services they use. In complex societies there is a division of labor and most persons are engaged in full-time (Pestoff, 2014).
}

Slik representerer co-production i sine ulike dimensjoner mange muligheter for fornyelse av det demokratiske mandat og en velferdspraksis som kan omfatte sosialt entreprenørskap, sosiale virksomheter, sivilsamfunnsorganisasjoner og intraprenørskap i offentlige organisasjoner, og er dermed av stor interesse fra et politisk, kommunalt, offentlig og forskningsmessig synspunkt.

Hybriditet er et annet forskningstema som står sentralt i definisjoner på og praktisk forståelse av sosialt entreprenørskap, sosiale virksomheter og sivilsamfunnsorganisasjoner. Disse virksomhetene setter rammer for profit- og non-profit-elementer og opererer derfor under en hybrid kryssild av oppgaver, utfordringer og vilkår som representerer konkurransefortrinn, men også problemer som kan påvirke forretningsideologi, misjon og verdiorientering (Mair and Noboa, 2003). Hybriditet omtales også som det flerfasetterte vesen som kjennetegner sosiale virksomheter. Dette omfatter multiple "stakeholders", multiple mål og multiple ressurser, som noen oppfatter som en spesifikk fordel, men som også kan betraktes som en potensiell svakhet på grunn av sin flyktige karakter og som dermed kan innebære en risiko for å påvirke/endre sosiale virksomheters struktur og misjon over tid (Bode, Evers and Schultz, 2006). Victor Pestoff presiserer at hybriditet fra en sivilsamfunnsorganisasjons synspunkt ikke bare handler om disse definisjonene, men i like stor grad - om ikke større - om tre forhold: For det første hvordan man kan mobilisere, fastholde og balansere ulike interessenters interesser sett i forhold til organisasjonens mål. For det andre hvordan en blanding av ulike mål kan fastholdes uten å miste støtte fra interessentene, og for det tredje hvordan det er mulig å 
skape synergi gjennom å trekke inn interessentenes individuelle og kollektive bidrag til målene (Pestoff, 2014).

Det som her fremheves, er altså de spesielle utfordringene og kravene som stilles til de hybride organisasjonene som skal balansere sosiale og økonomiske mål med demokrati og innflytelse. Og som sådan er det nødvendig å utvikle nye og innovative metoder som nettopp kan styrke sosiale virksomheters, kooperativers og andre sivilsamfunnsorganisasjoners strukturer for å sikre interne beslutningsprosesser som kan omfatte mange interessenter - samt utarbeide metoder for "social accounting" og "social audit" som kan fastholde og føre tilsyn med organisasjonenes sosiale og økonomiske innsats. Pestoff forutsier dessuten at hybriditet og hybride organisasjoner sannsynligvis vil få økt utbredelse (i den nordiske velferdsstat) gjennom den kontinuerlige utviklingen av et stadig mer fragmentert og pluralistisk offentlig styresystem kjennetegnet ved New Public Management og New Public Governance. Dermed kan sivilsamfunnsorganisasjonene følge to mulige strategier for hybrid overlevelse: En strategi som retter seg mot større markedskonkurranse (som NPM) og som må navigere i både "pull and push"-logikkene fra sivilsamfunnet og markedet, styrke profesjonalisme, promotere markedsfordeler og økt effektivitet. Den andre strategien går ut på å bevare (flere) tradisjonelle sosiale verdier i en NPG-visjon gjennom å delta i servicenettverk som vektlegger "co-production" og "co-governance", som har et visst overlapp til den offentlige sektor, men også innebærer visse risikoer (Pestoff, 2014:10-11). Det er således interessant å fastslå at det er mulig å skissere ulike utviklingsscenarier for sosialt entreprenørskap og dets ulike former for organisasjoner - avhengig av hvilken strategi den enkelte sosialøkonomiske organisasjon vil følge. Samtidig er det likevel viktig å vurdere hvilke samfunnsmessige, økonomiske og strukturelle forhold som må være til stede for å sikre at det er snakk om et reelt valg.

En rekke nordiske enkeltstående casestudier undersøker hybride sosiale virksomheter - både med hensyn til deres styrker og svakheter - og bidrar dermed med et nyttig og kritisk blikk som både bekrefter og nyanserer ovennevnte tendenser og karakteristikker. Gjennom sin forskning viser Andersen og Hulgård hvordan den danske opplysningstradisjonen, ønsket om empowerment, markedsbaserte dynamikker samt oppkvalifisering av og jobbtrening for sårbare borgere er elementer i et dansk WISE (work integration social enterprise), som viser seg romme et potensial for oppsiktsvekkende resultater, men som mangler de nødvendige rammer og forutsetninger i form av en blandingsøkonomi med langsiktig bærekraft (Andersen og Hulgård, 2009). Charlotte Rosenberg gir i sin forskning et eksempel på hvordan en dansk sosialøkonomisk og sivilsamfunnsorga- 
nisasjon klarer å fastholde og kvalifisere utsatte og sårbare borgere ved hjelp av en særlig romlig, pedagogisk og interrelasjonell struktur med organiserte og åpne rom. Det er viktig for alle involverte at det er flytende overganger mellom å være bruker, frivillig og aktivert samt at det er mulig å veksle mellom disse posisjonene, da det vil gi muligheter for vekst på flere måter som virker subjektiverende (Rosenberg, 2013). Malin Gawell gjør en casebasert analytisk studie av hvordan svenske sosiale virksomheter og "samhällsentreprenörskap" rettet mot ungdomsaktiviteter kan forstås med utgangspunkt i entreprenørbegrepene "opportunities, needs and/or perceived necessities". Hun påviser et dynamisk samspill mellom muligheter og behov, hvor engasjement og tiltak særlig overfor ungdomsgrupper enkelte ganger går opp i en høyere enhet, men også andre situasjoner hvor det oppstår en motsetning mellom entreprenørmulighetene og de unges egne behov og ønsker (Gawell, 2013). Endelig tar Ulrika Levander utgangspunkt i en kvalitativ caseanalyse av tre svenske sosiale virksomheter og belyser hvordan de på den ene side evner å danne sosiale og kulturelle identitetsskapende prosesser som utfordrer diskriminering og ekskludering av utsatte grupper. På den annen side er det imidlertid uklart i hvor stor grad sosiale virksomheter bidrar til å redusere marginalisering slik det hevdes i politisk retorikk, men dette mangler forskningsbasert dokumentasjon (Levander, 2012).

I nordisk forskning finnes det et økende antall kvalitative, enkeltstående casestudier som belyser sosialt entreprenørskap, sosiale virksomheter og sivilsamfunnsorganisasjoner - helt i tråd med internasjonal forskning, mens det mangler metastudier og større, kvantitative og kvalitative komparative studier som belyser effekter og resultater.

\subsubsection{Eksperimentelle laboratorier for velferdstjenester og særlig utsatte borgere}

Mye av den nordiske forskningen gransker og vurderer sosialt entreprenørskap, sosiale virksomheter og sivilsamfunnsorganisasjoner som en slags eksperimentelle laboratorier for nyutvikling av velferdstjenester samt hvordan utsatte grupper av borgere og enkeltindivider kan finne bedre fotfeste gjennom utvikling, kompetanseutvikling og medborgerskap. Nordisk forskning spenner vidt og omfatter en rekke temaer om for eksempel sosialt entreprenørskap. Sosiale virksomheter belyses i konstellasjoner som "corporate sustainability strategies, social entrepreneurship and institutional theory" (Hockerts og Wünstenhagen, 2010; Agrawal og Hockerts, 2013), designtenkningens bidrag til sosiale virksomheters verdiskapning (Krull, 2013), om pedagogikk og didaktikk 
i entreprenørskapsundervisningen i et foretaksomhetsperspektiv (Kirketerp, 2010), sosial verdiskapning og økonomiske interesser i sosialt entreprenørskap som et innovasjonsfelt mellom samarbeid og styring (Fæster, 2013) samt studier av opprinnelsen til sosialt entreprenørskap gjennom eksplorative casestudier av danske og britiske sosiale virksomheter (Kulothungan 2014).

I Sverige er koblingen mellom "socialt företagande" og det "civila samhällets entreprenörskap" tydelig. "Den svenske regjeringen er spesielt opptatt av sosialt entreprenørskap i forhold til arbeidskraftmobilisering, og har utarbeidet en handlingsplan for arbeidsintegrerende sosiale foretak, som ble lagt frem i 2010. Der ble det lagt vekt på at sosialt entreprenørskap kan utgjøre et alternativ til og en bro mellom offentlige myndigheter, arbeidsliv, næringsliv og frivillig sektor" (Gustavsen og Kobro, 2012). I Danmark er det opprettet to sentre, Center for Socialt entreprenørskab og Center for socialøkonomi, gjennom store bevilgninger fra en spesiell sosialpolitisk regjeringsgruppe (Satspuljen) som over en årrekke skulle utvikle, forske og etablere undervisning og kapasitetsutvikling innenfor sosialt entreprenørskap, sosiale virksomheter og sivilsamfunnsorganisasjoner. Center for Socialt entreprenørskab har en særlig forpliktelse når det gjelder å belyse hvordan og hvorvidt sosialt entreprenørskap og sosiale virksomheter kan fungere i forhold til spesielt utsatte grupper (Hulgård, Andersen, Bisballe og Spear, 2008). I Finland utvikler sosialt entreprenørskap og sosiale virksomheter seg i faser, med en ny sosial bevegelse i sentrum som et arbeidsmarkedsinitiativ, en innsats/et fenomen for å fornye velferdsytelsene og endelig til en institusjonalisering (Kostilainen og Pättiniemi, 2014). Men også her finnes det altså en dimensjon som er spesielt rettet mot utsatte borgere.

Når det gjelder de nordiske landene, kan vi konkludere med at det er en sterk tendens til at sosialt entreprenørskap og sosiale virksomheter knyttes til velferdstjenester og løsninger hvor sårbare borgere trekkes inn, og hvor forbedringer av deres levevilkår og velferd står i sentrum - samt at den innovative kraften som er et definisjonstrekk, kan virke fornyende for de nordiske velferdsstatene. Det vi ikke kan si noe om på nåværende tidspunkt er hvorvidt disse initiativene og tendensene har en varig effekt, om de blir iverksatt, hvordan og om de kan skaleres opp eller om de forblir nisjeprodukter som blusser opp for så å forsvinne igjen. Det krever et større forskningsarbeid for å belyse disse viktige spørsmålene. 


\subsubsection{Rammer og incitamentsstrukturer}

Vårt siste tema dreier seg om rammer og incitamentsstrukturer, hvilke elementer de omfatter samt deres betydning for sosialt entreprenørskap, sosiale virksomheter og sivilsamfunnsorganisasjoner. Vi belyser dette feltet med utgangspunkt i følgende figur, som omfatter fire dimensjoner: Forskning, utdanning, praksis og politikk, som er avgjørende for etablering, utvikling og konsolidering av sosialt entreprenørskap.

Figur 3.3. Rammer for sosialt entreprenørskap

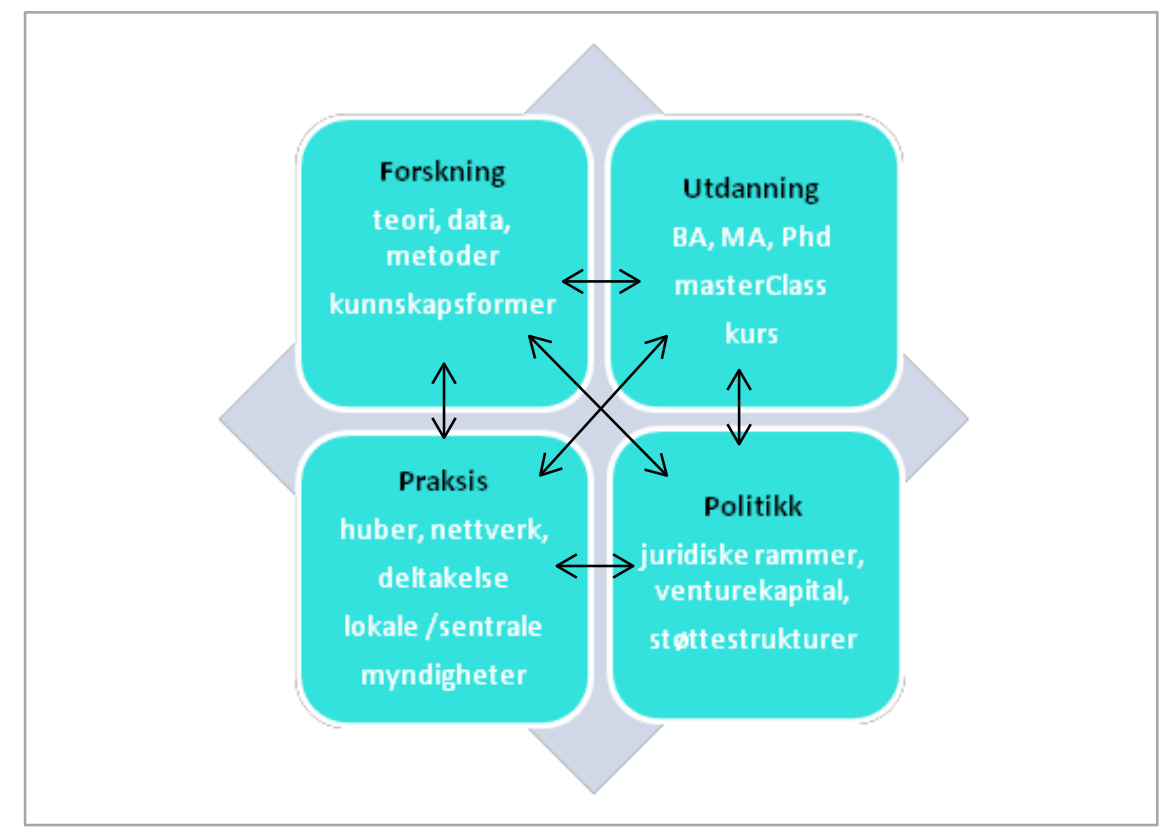

Model: Linda Lundgaard Andersen, 2014

Alle disse fire dimensjonene er kjent i de nordiske landene og gjenstand for utvikling og kvalifisering, selv om det er snakk om ulike grader av utfoldelse. For eksempel er den politiske dimensjonen med juridiske rammer, venturekapital og støttestrukturer utviklet i Finland, men i mindre grad i de øvrige nordiske land. I Sverige har det imidlertid periodevis vært stort politisk fokus på sosialøkonomi og sosialt entreprenørskap. Allerede i 1997 besluttet den daværende regjering å nedsette en arbeidsgruppe på tvers av departementene, som skulle utarbeide en rapport om "Social ekonomi i EU-landet Sverige - tradition och förnyelse i samma begrepp" (Regeringskansliet, 1998). Videre har den svenske stat gjennom 30 år gitt økonomisk støtte til det som i dag kalles Coompanion og som i henhold til opplysninger fra arbeidsgruppen blant annet har: 
bidragit starkt till utvecklingen av föräldrakooperativa daghem (massor), personalkooperativ inom vård och omsorg, arbetsintegrrande sociala företag och annat företagande som drivs av samhällsutmaningar och gemensamma behov.

Utdanningsdimensjonen, som i prinsippet dekker folkeskole, ungdomsutdanning, bachelor og masterutdanninger samt doktorgrader, er sannsynligvis sterkest etablert og befestet i Danmark, men er nå på gli i de øvrige nordiske landene: Her benyttes også huber, rådgivnings- og støtteforumer, inkubatorer og nettverksgrupper. Det viktigste poenget her er videre at disse fire feltene påvirker hverandre gjensidig, både i fremmende og hemmende henseender. For eksempel vil en omfattende utdanningsinnsats innenfor sosialt entreprenørskap, sosial virksomhet og sivilsamfunnsvirksomhet skape kunnskap, sosiale og kulturelle kapitalformer og økt handlingspotensial, noe som igjen vil påvirke praksis på mange forskjellige måter. Et solid utdannings- og praksisfelt vil videre kunne påvirke og føre til at den politiske dimensjonen kvalifiseres gjennom utvikling av sosiale, økonomiske og kulturelle støttestrukturer, som igjen vil kvalifisere praksis og utdanning. Det finnes altså et gjensidig avhengig, synergisk, men også til tider motsetningsfylt forhold mellom disse dimensjonene - på samme måte som innen ethvert nytt kunnskaps- og handlingsfelt - som virker, interagerer og kjemper om definisjonsmakt, ressurser og innflytelse.

\subsection{Avslutning: Fem punkter som kjennetegner SE og SI i Norden}

Både på EU-plan og i nasjonale og lokale sammenhenger blir det i stadig større grad formulert politikk og lovgivning, opprettet interesseorganisasjoner og gjennomført andre omfattende tiltak for å fremme sosiale virksomheter, sosialt entreprenørskap og den sosialøkonomiske sektor. Slik politikk og slike tiltak bidrar til en gradvis utvikling av et reelt organisatorisk felt av sosiale virksomheter og sosialt entreprenørskap. På europeisk plan vedtok EU-kommisjonen i 2011 to viktige tiltak for å fremme sosialt entreprenørskap i Europa. For det første ble det vedtatt en ny strategi for det indre marked, den såkalte "Single Market Act. Twelve levers to boost growth and strenghten confidence", som fastsatte rammene for samhandel med tanke på å skape ny vekst. I denne strategien utgiør sosialt entreprenørskap ett av 12 ulike verktøy for å skape en ny vekstmodell. Følgende sies om "Lever number 8: Social entrepreneurship" som skal bidra til å skape: 
inclusive, socially fairer and environmentally sustainable growth. New business models are being used, in which these societal concerns are taking precedence over the exclusive objective of financial profit...initiatives, which introduce more fairness in the economy and contribute to the fight against social exclusion, should be supported.... In order to expand and meet its objectives, the social economy sector in the Single Market should have at their disposal legal models adapted to their needs.

På denne bakgrunn lanserte EU-kommisjonen senere i 2011 et "Social Business Initiative" (Proposal No 36, 2011), som blant annet skulle bidra til å utvikle sosialt innovative virksomhetsprosjekter og innføre nye investerings- og finansieringsmodeller for sosiale entreprenører og virksomheter. Videre ble det lagt vekt på å skape bedre rammer for å ta sosiale hensyn i forbindelse med offentlige innkjøp og dermed gi offentlige myndigheter større mulighet til å handle med sosiale virksomheter.

Som vi har sett i dette kapittelet, hersker det ingen tvil om at sosialt entreprenørskap både i form av sosiale virksomheter og i form av andre sosiale innovasjoner etter hvert har bidratt til å prege en lang rekke samfunnsrelaterte områder. Sosialt entreprenørskap og sosial innovasjon innlemmes blant annet som selvstendige verktøy i nasjonale sivilsamfunnsstrategier, noe som på den ene side sannsynligvis bidrar til å gjøre sivilsamfunnsorganisasjonene mer innovative når det gjelder å generere ressurser og håndtere oppgaver. På den annen side svekker det muligens deres historiske tradisjon for "advocacy", deriblant muligheten til å kritisere regjeringer og offentlige myndigheter.

Det italienske forskningsinstituttet EURICSE har utviklet en modell (figur 3.4) som viser hvordan sosiale virksomheter utvikler seg over tid. 


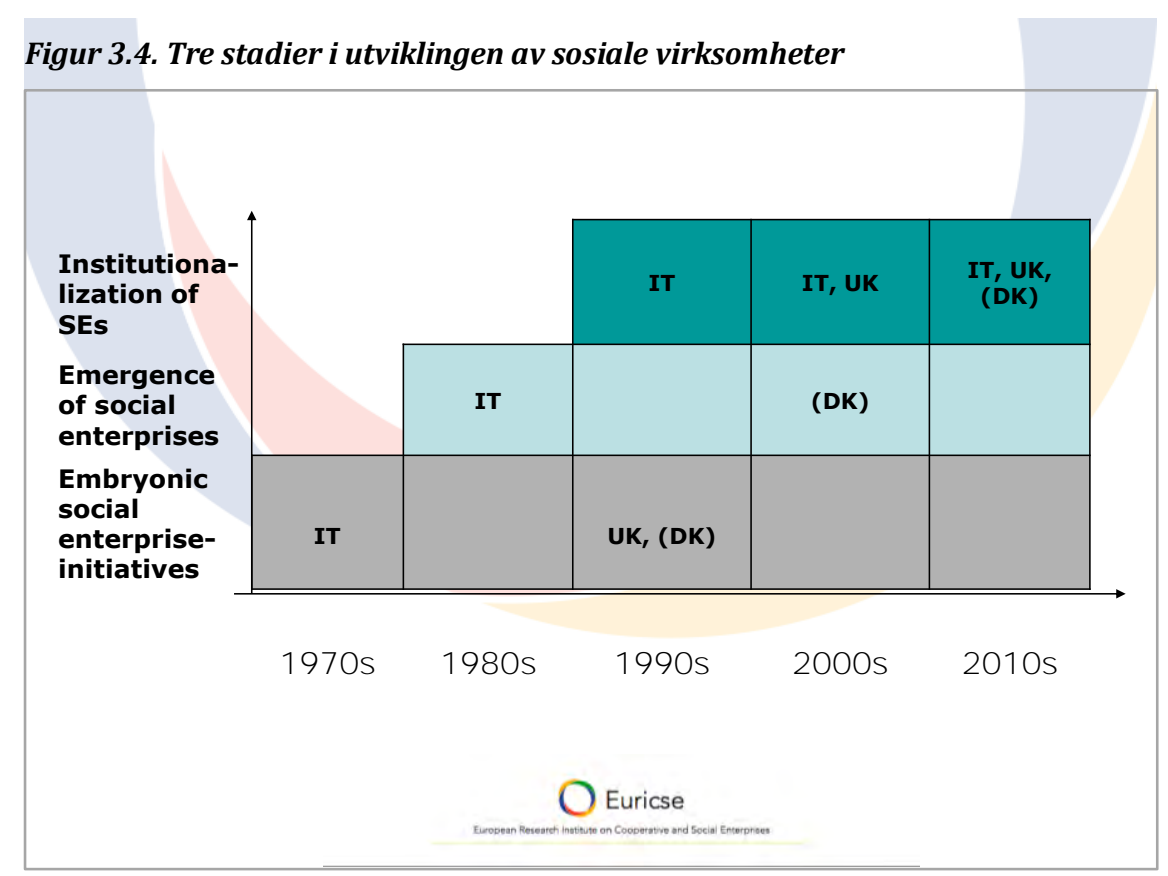

Figuren skisserer på glimrende måte hvordan SE utvikler seg over tid fra små og ofte spontane lokale tiltak til formelle institusjoner og virksomheter støttet av nasjonale og internasjonale programmer. Men samtidig er modellen kontroversiell, fordi den med rette kan kritiseres for sin italienske dreining, som hevder at Italia var et foregangsland i alle faser av institusjonaliseringen av SE som et markant samfunnsmessig fenomen. På den ene side egner den italienske modellen seg godt til å forstå de ulike fasene som stater og regioner gjennomgår i institusjonaliseringen av sosialt entreprenørskap og sosialøkonomisk virksomhet som viktig samfunnsmessig fenomen, fra den tidligste og kanskje uformelle fasen (embryonic) til institusjonaliseringen av nasjonale programmer og nasjonal politikk. På den annen side tar de italienske forskerne feil når de plasserer Italia øverst i alle de tre historiske fasene. Det vitner om manglende forståelse av historiske og institusjonelle variasjoner landene imellom. Alle land har således eksempler på sosiale virksomheter og sosiale entreprenører på første og andre nivå. Selv om det ikke har pågått noen debatt om "social enterprises" i Norden like tidlig som i land som Italia og Storbritannia, har det ikke desto mindre været en århundrelang historie av foreninger, bedrifter og andre organisasjoner på det sosialøkonomiske området. I denne sammenheng er det viktig å bemerke at utviklingen av "social enterprise" ikke bare skjer som etablering av nye virksomheter. Den skjer sannsynligvis i like stor grad gjennom endring av allerede eksisterende organisasjoner, både som en reaksjon på press fra myndigheter og gjennom andre former for tilpasning til nye 
omgivelser. De konkrete eksemplene og historiske erfaringene vil alltid være innbyrdes forskjellige, ettersom de gjenspeiler landenes særegne sosioøkonomiske, kulturelle og politiske utvikling. Noen land har en sterk kooperativ tradisjon (f.eks. Finland og Italia), mens andre har hatt sterke sivilsamfunnsorganisasjoner på sosiale og helserelaterte områder (f.eks. Tyskland) eller tradisjon for veldedighet og frivillighet (f.eks. USA). Fellesnevneren er at det fra alle disse regionale, nasjonale og lokale utviklingssammenhenger gradvis begynner å dannes en sektor for sosiale virksomheter og sosiale entreprenører som deler kjennetegn og også begynner å operere på internasjonale markeder og skaper internasjonalt orientert kompetanseutvikling og videregående utdanning. Med utgangspunkt i figur 3 "Rammer for sosialt entreprenørskap" kan vi derfor anta at det samlede felt av sosialt entreprenørskap og sosialøkonomiske virksomheter i Norden vil utvikle seg ytterligere i retning av en institusjonalisering som et reelt organisatorisk og samfunnsmessig betydningsfullt felt.

Modellen er ikke desto mindre relevant, fordi den viser at institusjonaliseringen av sosialt entreprenørskap og sosial virksomhet gjerne gjennomgår en rekke faser når man skal forstå deres samfunnsmessige betydning. Første fase er preget av hva de italienske forskerne kaller "sosialøkonomiske virksomheter på fosterstadiet". I nordisk sammenheng kan det være en frivillig forening som etablerer en kafé eller en systue som en del av virksomheten, med det formål å supplere den mer tradisjonelle virksomheten som ideell eller frivillig forening. Andre fase er at noen av disse organisasjonene begynner å oppfatte seg selv som "social enterprises". I Norden har denne prosessen fått støtte i form av forsøks- og fondsmidler fra private og offentlige kilder, noe som igjen har bidratt til en gradvis endring i retning av et mer entreprenørorientert og innovativt sivilsamfunn. Forskere har påpekt at viktige indikatorer peker i retning av at:

de nordiske sivilsamfunnsorganisasjoner i økende tempo hopper på "the corporate way" ved å bli stadig mer forretningspregede (Wijkström \& Zimmer, 2011: 22).

Eller utvikler en rekke "hybride organisasjoner", som på ulike måter beveger seg $\mathrm{i}$ et kontinuum mellom frivillige sivilsamfunnsorganisasjoner, offentlig subsidiering og privat drift gjennom delvis markedsbasering. Tredje fase er at den sosialøkonomiske bevegelse anerkjennes og systematisk understøttes på politisk nivå. Det skapes både lovgivningsmessige rammer og offentlige støttestrukturer på internasjonalt, nasjonalt og lokalt plan. 
Imidlertid er det viktig å bemerke at utviklingen av sosial virksomhet som et bredere samfunnsmessig fenomen også kan være det omvendte av måten som modellen foreskriver. Vedtak av nye lover, endrede rammebetingelser og støttestrukturer kan i en lang rekke tilfeller være det første skrittet mot utvikling av SE. Med vedtaket av nye lover og endrede vilkår for statlig støtte og tilgang på økonomiske ressurser får eksisterende organisasjoner dermed muligheten til å tilpasse seg det nye regelverket og oppnå status som sosial virksomhet. Dette har blant annet skjedd med den britiske CIC (Community Interest Company), som ble innført i 2005 og gjorde det mulig for allerede eksisterende virksomheter å omdanne seg til sosiale virksomheter. Noe tilsvarende må man anta vil skje med vedtaket av både nye reguleringer på EU-nivå og den danske "Lov om registrerede socialøkonomiske virksomheder", som ble vedtatt av det danske folketinget i juni 2014.

Det er vår påstand at vi på ulike måter nå beveger oss på andre og tredje nivå i de nordiske landene. Det er umulig å plassere Norden som sådan på et av de tre nivåene, men vi er forbi det første nivået, hvor det bare er snakk om sporadiske initiativ som kanskje ikke en gang blir omtalt som sosial virksomhet og sosialt entreprenørskap. Det finnes variasjoner landene imellom, men også en rekke likheter som det er viktig å huske på når løypen for den fremtidige utvikling skal gås opp. Dette vil vi avslutningsvis forsøke å spissformulere med fire punkter som kjennetegner sosialt entreprenørskap i Norden.

\subsubsection{Den universelle velferdsstat har historisk sett vært en aktiv partner i utviklingen av sosialt entreprenørskap på nasjonalt og kommunalt/lokalt nivå}

Internasjonalt har de nordiske landene vært kjent som "state friendly societies". Det høye nivået av tillit og sosial kapital skyldes i stor grad en balansert utvikling mellom aktive, dynamiske og forhandlingsvillige samfunnsrelaterte sektorer (stat, marked og sivilsamfunn). Den anerkjente statsviteren Robert Putnam, som har forsket på sammenhengen mellom sosial kapital og politiske institusjoner, forholdt seg under et intervju i 1999 til forholdet mellom sosial kapital og velferdsstaten i de nordiske land. Spørsmålet lød som følger: How does the universal welfare state in the Nordic countries relate to social capital?

When speaking to American audiences I often provide one kind of evidence showing that across the OECD countries, in so far as we do have measures, we have imperfect measures of social capital, there is a strong positive not negative correlation between social capital and the size of the welfare state. 
The societies in which there is the highest level of social trust and group membership are precisely the Scandinavian countries which also have the most generous welfare states. And the countries that have the smallest welfare state or no welfare states at all tend to be the countries that also have low levels of social capital..(..)...Now of course a correlation does not in itself tell us in which way the causal arrow points, it's not clear, and it's not clear to me even whether the welfare state itself actually produces social capital or whether places that are high in social capital have feelings of social solidarity, and therefore support more expensive welfare programs. So it is possible that the social capital produces the welfare state, it's also possible that it's the welfare state that produces the social capital. But it's certainly not possible, it seems to me, that the welfare state in general destroy social capital (Putnam, 1999).

På samme måte som vi kan se en positiv korrelasjon mellom den universelle velferdsstat i de nordiske land, kan vi forvente at denne historiske erfaringen får avgjørende betydning for et særegent nordisk bidrag til den internasjonale debatten om sosialt entreprenørskap og sosial innovasjon. Norden har en tradisjon for "starkt statligt engagemang i alla samhällsområden" og "enhetliga kriterier för grundläggande mänskliga behov" (Seppelin, 2014). Med den gradvise privatiseringen og individualiseringen av sosialt ansvar også i de nordiske landene, blir det viktig å forholde seg kritisk og analytisk til hvorvidt institusjonaliseringen av sosialt entreprenørskap som organisatorisk felt vil bidra til ytterligere privatisering eller vil inngå i en ny form for offentlig-privat samarbeid, som vi ennå ikke kan se konturene av (se figur 2). På den måten knytter utviklingen av sosialt entreprenørskap seg også direkte til hvilke generelle styringsparadigmer (governance) som skal regulere de nordiske velferdsstatene i årene som kommer: Vil vi se en skjerping av konkurransestaten med dens antakelse om "at sociale relationer er af økonomisk karakter" (Petersen, 2011: 188) og New Public Management (NPM) basert på tanken om "the superiority of private-sector managerial techniques" (Osborne, 2010: 3)? Eller vil sosialt entreprenørskap og sosial innovasjon inngå i utviklingen av mer nettverksorienterte og forhandlingsbaserte modeller for New Public Governance, som blant annet bygger på nye former for samproduksjon og hybride organisasjoner hvor den tredje sektor inntar en viktig posisjon (Pestoff, 2009)? Det interessante er at SE og SI kan inngå som viktige "virkemidler" i begge scenarier, men i to vesensforskjellige utgaver. Kanskje ser vi et element av NPG i den svenske utviklingen av "Offentligt - Socialt Privat partnerskap", hvor det ifølge opplysninger fra arbeidsgruppen inngås avtaler "som staten och kommuner gör med civilsamhällets organisationer. Hittills finns dessa överenskommelser på det sociala området (inkl arbete för t ex funktionsnedsatta) och integrationsområdet." Dette 
med tanke på å utvikle samarbeidet mellom det offentlige og sivilsamfunnet og i det hele tatt utvikle og tydeliggjøre spillereglene for et samarbeid på tvers av sektorer.

\subsubsection{Sosialt entreprenørskap foregår $\mathrm{i}$ et samspill mellom de tre sektorene stat, marked og sivilsamfunn}

På samme måte som i andre områder av verden har det sivile samfunn i Norden spilt en viktig rolle for utviklingen av sosialt entreprenørskap. På nordisk plan er vi sterkt påvirket av "medborgarorganisationer", foreningsliv, "folkrörelser", ideelle organisasjoner, kooperativer og så videre. Over tid har sivilsamfunnets nyskapende evne til å generere innovasjon neppe blitt mindre, men det har snarere skjedd en endring i offentlige myndigheters regulering og samhandling med de øvrige sektorene:

\footnotetext{
Det har inte skett någon förändring i civilsämhällets nyskapande kapacitet - att genera nya innovationer. Det som har förändrats är relationen mellan staten/kommunerna och organisationerna som tillhör den tredje sektorn. Den offentliga sektorn tar inte längre över samhällsnyttiga innovationer in till sina egna organisationer och sprider dem effektivt runt över landet i samma grad som förr. I takt med nya juridiska rambetingelser (EU-rätten) har direkt statligt stöd till affärsmässiga näringsaktiviteter minskat väsentligt för att inte snedvrida konkurrensen. Organisationerna inom den tredje sektorn som bedriver också ekonomiska verksamheter (s.k. näringsidkare) har utsatts för hård konkurrens. Stora marknadsaktörer köper mindre spelare ut från marknaden ifall de börjar ha ett större kommersiellt värde. Man har tvingat många exixterande organisationer utan vinstintresse att omvandla sig till "sociala entreprenörer (Seppelin, 2014; Koskiaho, 2014).
}

\subsubsection{Sosialt entreprenørskap dreier seg om annet og mer enn arbeidsplasser for sosialt utsatte}

Skal strategier og politikk for sosialt entreprenørskap hovedsakelig rettes mot å integrere sosialt utsatte grupper på arbeidsmarkedet, eller er det viktig også å inkludere områder som sosiale tjenester, kultur, utdanning, miljø og helse? Hvis sosialt entreprenørskap først og fremst oppfattes som en ny teknologi for å fremme sysselsetting blant sosialt utsatte grupper, kan politikken rettes mot å fremme de såkalte WISE (Work Integration Social Enterprises). Men i gitte tilfeller vil det være en fare for at det historiske potensialet som er opparbeidet gjennom flere tiår i de nordiske velferdsstatene, ikke vil bli fullt utnyttet i politikk og pro- 
grammer for sosialt entreprenørskap. De nordiske land har således en tradisjon for:

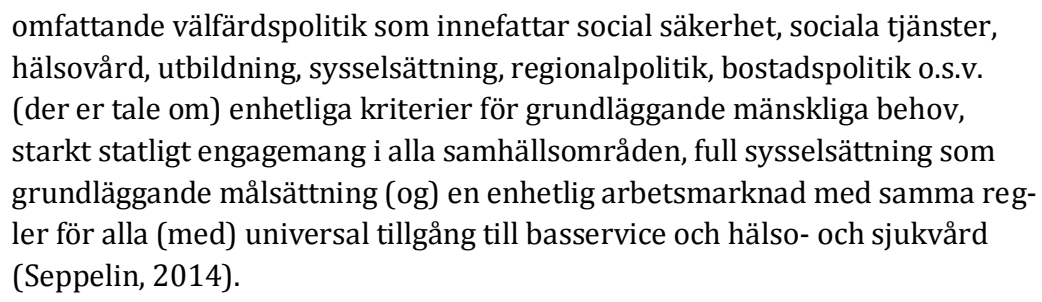

Hvis det utelukkende satses på sysselsettingsfremmende sosiale virksomheter (WISE), vil kreativiteten og tradisjonen for samarbeid mellom innovatører i alle samfunnssektorer ikke kunne nyttiggjøres med tanke på å øke den nødvendige sosiale kapital og solidaritet og bidra til å skape et nytt nivå for velferdssamfunnet.

\subsubsection{Sosialt entreprenørskap åpner for et nytt velferdsstatlig nivå - SE som eksperimentelle arenaer for deltakende, læringsrelaterte og produktive velferdsarenaer}

Bureau of European Policy Advisers, et ekspertpanel som formannen for EU-kommisjonen kan sette til å utføre analyser av konkrete samfunnsmessige brennpunker, utga i 2010 en rapport om "Social Innovation in the European Union". Her definerte ekspertgruppen sosial innovasjon som "Social value by providing new solutions to unsolved social challenges through participatory and empowering processes" (BEPA, 2010). Dette er interessant av to grunner. Først fordi sosial innovasjon og sosialt entreprenørskap her karakteriseres som et arbeid som er prinsipielt viktig på alle områder hvor samfunnet har uløste sosiale utfordringer og ikke bare på sysselsettingsområdet. Dernest fordi produktet av sosial innovasjon (social value) ikke kan atskilles fra prosessen. BEPA understreker således at sosial innovasjon og sosialt entreprenørskap skapes gjennom prosesser som oppmuntrer til "participation" og "empowerment". Det vil si at innovasjonen og innsatsen utvikles i samarbeid med og respekt for de ulike aktørgruppene som er involvert. Her er det i høy grad snakk om et sammenfall av både "co-production", co-governance" og "co-management". Dette er en tilnærmingsmåte som de nordiske landene har et solid historisk utgangspunkt for å videreutvikle til et nytt velferdsnivå, på samme måte som den universelt orienterte nordiske velferdsmodellen i etterkrigstiden ble en av megainnovasjonene som har vekket mest oppmerksomhet på verdensplan. 



\section{Deltakelse i arbeid og samfunnsliv i de nordiske landene}

Formålet med denne delen er å gi et overblikk utfordringer de nordiske landene står overfor i arbeidet for å inkludere utsatte grupper i arbeidsog samfunnsliv. Vi gir en kort beskrivelse av hvor mange som er utenfor arbeids og samfunnsliv ved hjelp av komparative indikatorer, og vi trekker også fram kjennetegn ved grupper som er spesielt utsatte.

\subsection{Status og utviklingstrekk i Norden}

Norden er en region preget av høy sysselsetting når en sammenligner med resten av Europa. ${ }^{4}$ Det er spesielt den høye sysselsettingen blant kvinner som fører til at Norden har høy sysselsetting i europeisk sammenheng. Figur 4.1 viser andelen sysselsatte i aldersgruppen 20-64 år. ${ }^{5}$

Island har gjennomgående den høyeste sysselsettingen i Norden, årsgjennomsnittet for andelen sysselsatte i alderen 20-64 år 82,8 \% i 2013. Finland har den laveste andelen sysselsatte med 73,3 \% i 2013. Går vi ti år tilbake i tid, var forskjellene mellom de nordiske landene noe større, og det var en klarere tredeling der Island hadde den klart høyeste og Finland den klart laveste sysselsettingen, mens Norge, Sverige og Danmark i et mellomsjikt. Dette bildet holdt seg nokså uendret fram til finanskrisen i 2008.

\footnotetext{
${ }_{4}^{4}$ Personer blir regnet som sysselsatte dersom de har utført minst en time inntektsgivende arbeid i en referanseuke, eller vært midlertidig fraværende fra slik arbeid i referanseuka.

${ }^{5}$ Vi har valgt denne aldersavgrensningen fordi å unngå å få med yngre som i hovedsak forventes å være videregående utdanning, og eldre som har nådd en alder der det er muligheter for tidlig pensjon.
} 
Figur 4.1. Sysselsatte i alderen 20-64 år, 2003-2013. Prosent

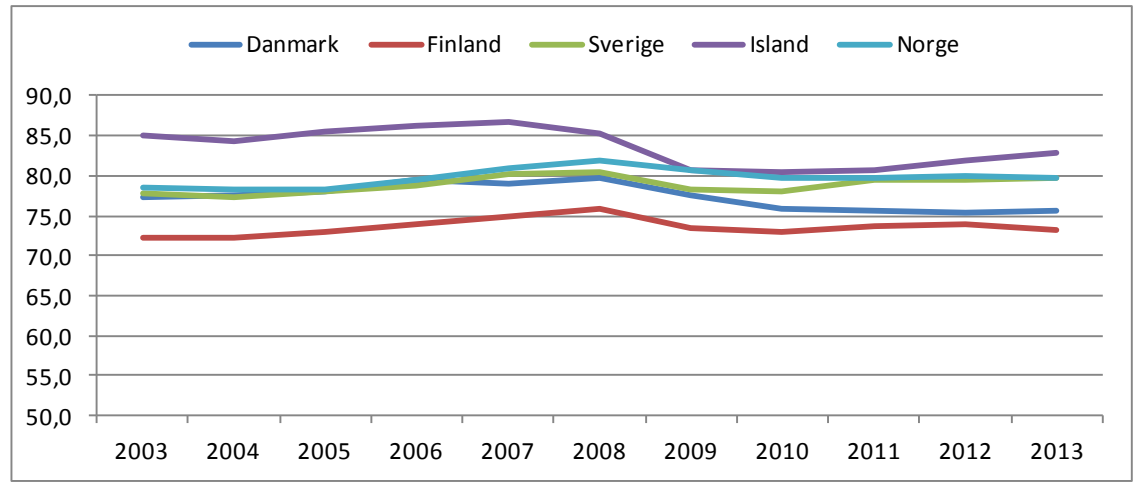

Kilde: Eurostat, LFS (04.06.2014).

Etter 2008 falt sysselsettingen i alle nordiske land. Størst var nedgangen i Island hvor sysselsettingen i 2010 var 6,3 prosentpoeng lavere enn i toppåret 2007. I 2012 og 2013 har imidlertid sysselsettingen økt igjen. Sysselsettingen i Sverige ble mindre redusert etter 2008, og også her har andelen økt noe igjen etter 2010. Norge var det landet med minst reduksjon i sysselsettingen etter finanskrisen, og nivået har stabilisert seg etter 2009. I Danmark har utviklingen vært noe mer negativ, og fra å ha sysselsetting på nivå med Norge og Sverige, har sysselsettingsandelen i den gjeldende aldersgruppen falt ned til i overkant av $75 \%$. Det er bare om lag to prosentpoeng høyere enn i Finland, der andelen ar variert mellom 73 og 74 \% årene etter finanskrisen.

Nedgangen i sysselsettingen i Norden flatet altså relativt raskt ut etter finanskrisen. Sammenligner vi ti år tilbake i tid, er dessuten sysselsettingen i Norge, Sverige og Finland noe høyere i 2013 enn den var i 2003. I Island og Danmark er den noe lavere. Dette har da også medført at den klare tredelingen vi så i 2003 er endret, og forskjellen mellom høyeste og laveste nivå i Norden er mindre.

Bak disse forskjellene og denne utviklingen ligger det naturligvis flere faktorer. Vi skal ikke gå inn på disse i detalj, men blant annet kan noe av årsaken til lavere sysselsetting i Finland være at innslaget av deltidsarbeid er mindre enn i andre nordiske land. Gjennomgående er det også slik at kvinner har hatt en relativt sett mer positiv utvikling i sysselsetting enn menn de siste ti årene, med unntak for Sverige. Selv om andelen sysselsatte menn fremdeles er høyere enn andelen sysselsatte kvinner, er denne forskjellen mindre i 2013 enn den var i 2003. Noe av dette skyldes at menn ble hardere rammet av finanskrisen enn kvinner. Island og Danmark er de landene med størst forskjell mellom kjønnene, mens kjønnsforskjellen er minst i Finland. 


\subsubsection{Arbeidsledighet}

Arbeidsledighet gir et litt annet bilde av arbeidsmarkedet i Norden enn sysselsettingsandeler (Figur 4.2). ${ }^{6}$ Norge har den laveste ledigheten med 3,5 \% i 2013, og ledigheten har holdt seg relativt lav gjennom hele tiårsperioden. Selv om den økte noe som følge av finanskrisen, er nivået i 2013 likevel lavere enn i perioden 2003-2005. Fram til og med 2007 var ledigheten lavere i Island enn i Norge. Finanskrisen var også merkbar for arbeidsledigheten på Island, og den nådde et toppunkt på 7,6 \% i 2010. Etter det har nivået falt noe igjen, men er fremdeles 5,4 \% i 2013. Danmark hadde en tilsvarende utvikling som Island etter finanskrisen, med kraftig økning i ledigheten fra 3,5 \% i 2008 til 7,6 \% i 2011. Danmark har imidlertid ikke hatt samme nedgang som på Island de siste årene, og ledigheten var 7,0 \% i 2013. Sverige og Finland har hatt en nokså parallell utvikling i årene etter finanskrisen, og har ledighet på henholdsvis 8,0 og 8,2 \% i 2013. For Finlands del er dette imidlertid lavere enn i 2003, da ledigheten var på 9,0 \%. I Sverige var ledigheten lavere i årene 2003-2005.

Generelt kan vi si at utviklingen fram til 2008 stort sett var positiv med fallende arbeidsledighet $\mathrm{i}$ hele Norden, men at finanskrisen skapte merkbare effekter i form av økt ledighet. I likhet med sysselsetting stoppet den negative utviklingen relativt raskt, og ledigheten i 2013 var noe lavere enn de høyeste nivåene som ble nådd i 2010. I europeisk sammenheng er ledigheten i Norden relativt lav. I 2013 hadde Norge det laveste nivået i Europa, mens bare Østerrike og Tyskland hadde lavere nivå enn Island. Selv om ledigheten i Danmark, Sverige og Finland var høyere, var også det blant de lavere ledighetsandelene i Europa, og under gjennomsnittet for EU-28 (10,8 \%) og for Eurosonen (12,0 \%).

\footnotetext{
${ }^{6}$ Arbeidsledige er definert som alle personer fra 15 til 74 år, som ikke var sysselsatte i referanseuken, og som aktivt hadde søkt arbeid i løpet av de fire siste ukene, og som var klare for å begynne i arbeid enten umiddelbart eller i løpet av to uker. Sammenheng mellom begrepene: Arbeidsledige + Sysselsatte $=$ Arbeidsstyrken . Arbeidsstyrken + Utenfor arbeidsstyrken = Befolkningen. Siden andel sysselsatte er oppgitt som andel av befolkingen mens andel arbeidsledige er oppgitt som andel av arbeidsstyrken, vil dermed ikke disse to tallene summere til 100 .
} 
Figur 4.2. Arbeidsledige i alderen 15-74 år, 2003-2013. Prosent

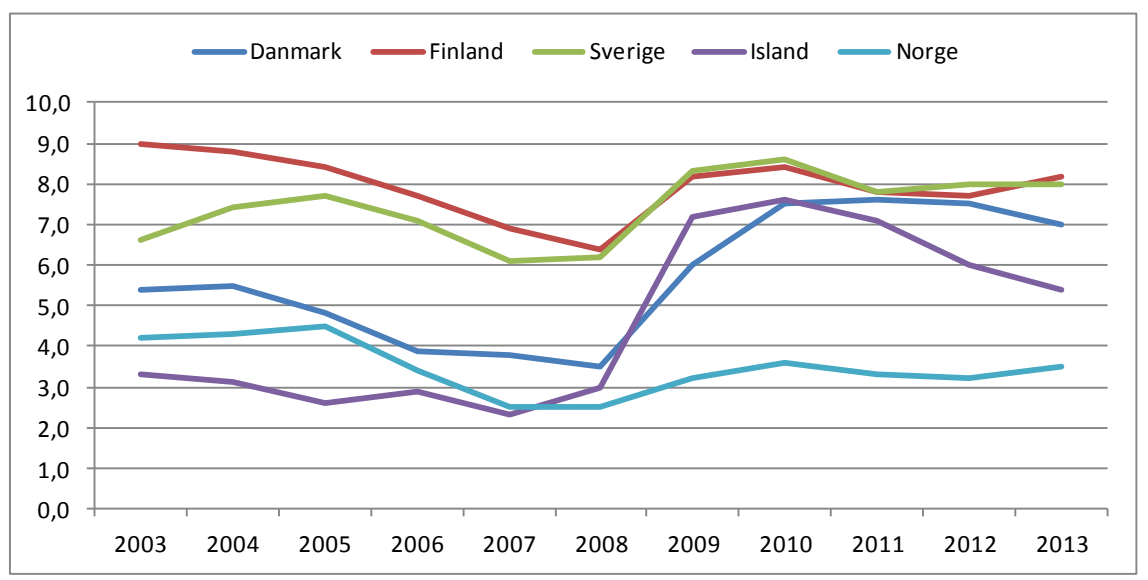

Kilde: Eurostat, LFS (04.06.2014).

\subsubsection{Marginalisering, ekskludering og uførhet}

Sysselsetting og arbeidsledighet fanger ikke opp hele spekteret av tilknytning eller manglende tilknytning til arbeidsmarkedet. Personer som arbeider noe, men befinner seg i randsonen av arbeidsmarkedet (marginaliserte) fanges ikke opp, det gjør også i liten grad personer som er ekskluderte fra arbeidsstyrken, enten det er på grunn av svekket helse eller av andre årsaker. I en NOSOSKO rapport fra 2013 (NOSOSKO 52:2013) presenteres det indikatorer for dette for perioden 2006-2010, her sammenfattet i figur 4.3.

Finland har stort sett hatt de høyeste andelene marginaliserte, ekskluderte og uføre i Norden, med unntak av at både Norge og Danmark hadde høyere andeler uføre i 2010. Island kommer relativt godt ut på alle tre indikatorer. Spesielt gjelder dette fram til 2009. I 2010 var forskjellen sammenlignet med de andre landene mindre fordi både uførhet, marginalisering og ekskludering økte. Danmark hadde en positiv utvikling både for marginalisering og ekskludering fram til og med 2009, og hadde da de laveste andelene i Norden, men utviklingen snudde i 2010. Når det gjelder uførhet kommer Danmark relativt sett dårligere ut. Norge har relativt lave andeler marginaliserte og ekskluderte, og det spesielle var at andelene gikk ned også mellom 2009 og 2010. I Norge er det imidlertid relativt høye andeler uføre. Sverige er ikke så ulikt Norge når det gjelder marginaliserte og ekskluderte, selv om andelene var noe høyere, spesielt i 2010. Svenskene er imidlertid sjeldnere uføre, bare Island har lavere andeler i Norden. 
Figur 4.3. Marginalisering, ekskludering og ufør eller ute av stand til å arbeide, personer 20-64 år, 2006-2010. Prosent av alle

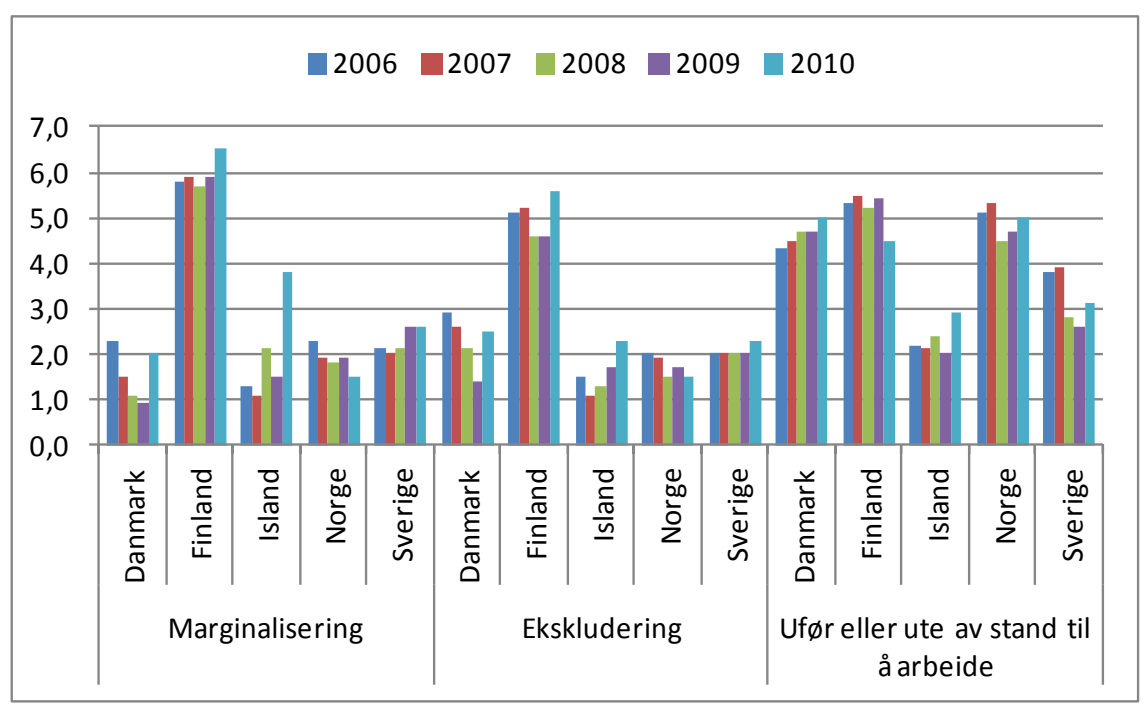

Kilde: EU-SILC 2006-2010, User Data Base.

Utviklingen i marginalisering, ekskludering og uførhet gir ikke noe entydig bilde av utviklingen i Norden. Disse indikatorene gir heller ikke helt det samme bildet av arbeidsmarkedet som sysselsetting og arbeidsledighet. Resultatene styrker likevel inntrykket av at Island ble hardest rammet av finanskrisen - ikke bare gikk sysselsettingen ned og arbeidsledigheten opp, det ble også flere som befant seg i randsonen og helt utenfor arbeidsmarkedet. Danmark så ut til å være inne i en positiv utvikling fram mot 2009, men det ser ut til at situasjonen forverret seg i 2010. Også i Finland gjelder delvis dette, men en nedgang i andelen uføre i 2010 gjør likevel at utfallet er noe mer positivt. Sverige ser ut til å ha blitt relativt lite berørt av finanskrisen, selv om det er antydninger til at flere er i randsonen og utenfor i 2010 enn i årene før. Reduksjon i andelen uføre nyanserer bildet for perioden sett under ett også for Sverige. Norge er det landet hvor vi ser færrest spor av finanskrise, sett under ett var det en positiv utvikling for alle tre indikatorer i perioden 2006-2010.

\subsubsection{Fattigdomsrisiko og sosial ekskludering}

Indikatorer på fattigdom og inntektsforskjeller kan også si noe om sosial inkludering og innbyggernes muligheter til gode levekår. En sentral del av EUs 2020 strategi er å promotere sosial inkludering gjennom reduksjon av fattigdom, og det konkrete målet er å løfte 20 millioner innbyggere ut av risiko for fattigdom eller sosial ekskludering. Dette 
måles ved hjelp av en egen indikator, der resultater for Norden presenteres i figur $4.4 .^{7}$

Figur 4.4. Personer med risiko for fattigdom eller sosial ekskludering, 2004-2012. Prosent

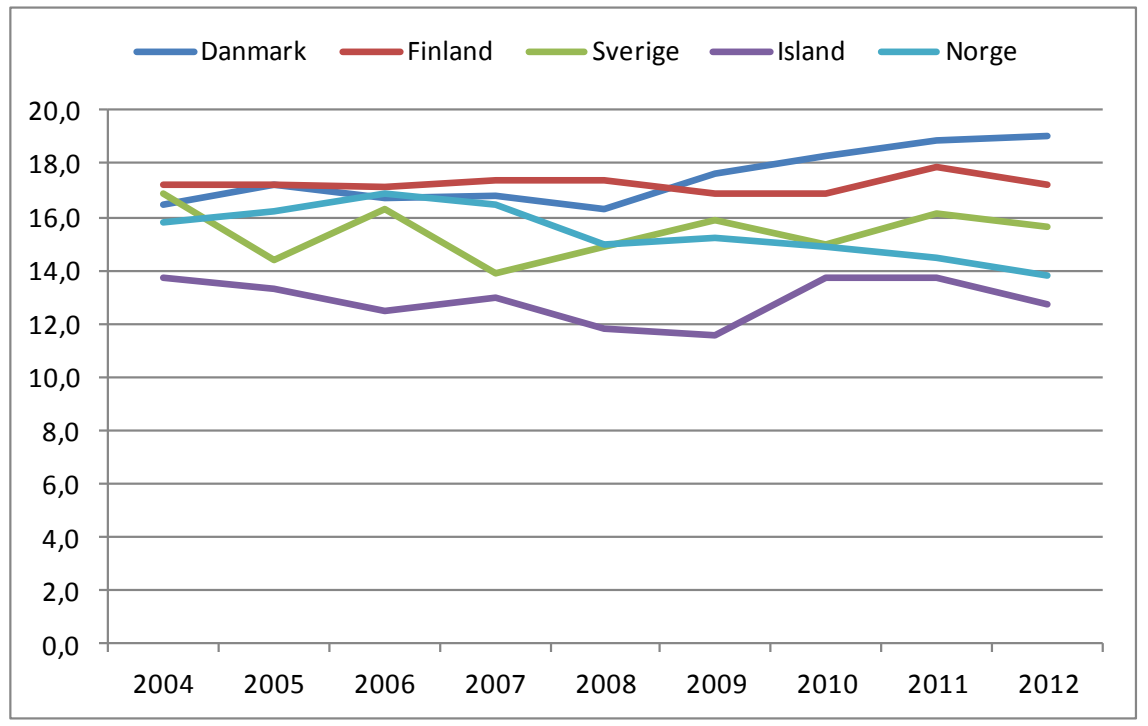

Kilde: Eurostat, SILC (06.06.2014).

I europeisk sammenheng er andelene i Norden lave. I 2013 var Island $(12,7 \%)$ og Norge $(13,8 \%)$ de to landene med lavest andel i Europa. Også Sverige (15,6 \%), Finland (17,2 \%) og Danmark (19,0 \%) var i det lavere sjiktet. Gjennomsnittet i EU-28 var 24,8 \%. Totalt sett kan vi dermed si at det er relativt stor likhet innad i Norden, siden alle de nordiske landene tilhører de 13 landene i EU/EøS som hadde under $20 \%$ på denne indikatoren. Til forskjell fra indikatorer for tilknytning til arbeidsmarkedet, viser ikke denne indikatoren store utslag av finanskrisen i de nordiske landene, selv om vi kan spore en viss økning i Danmark etter 2008.

\footnotetext{
${ }^{7}$ Indikatoren viser summen av personer som enten faller under grensen for fattigdomsrisiko eller opplever alvorlige materielle mangler, eller bor i en husholdning med lav arbeidsintensitet. Fattigdomsrisiko måles ved at man er under $60 \%$ av nasjonal median for ekvivalensinnktet. Materielle mangler er mål ved at man mangler minst 4 av følgende goder: Ikke råd til a) å betale husleie eller boutgifter, b) holde boligen passe varm, c) møte uforutsette utgifter, d) spise kjøtt, fisk eller tilsvarende vegetarkost annenhver dag, e) en ukes ferie borte fra hjemmet, f) privatbil, g) vaskemaskin, h) farge TV, eller i) telefon. Personer i hu sholdninger med lav arbeidsintensitet er personer i alderen 0-59 år hvor voksne husholdningsmedlemmer (18-59 år) arbeider mindre enn $20 \%$ av deres totale arbeid spotensial foregående år.
} 
En av delindikatorene i risiko for fattigdom og sosial ekskludering er lavinntektsmålet ofte benevnt som "EU60" (At-risk-of poverty). I en del sammenhenger benyttes dette som et mål på fattigdom, selv om det i praksis er et mål på inntektsfordeling. I Norden gir lavinntekt målt på denne måten andeler fra 14,1 \% i Sverige til 7,9 \% i Island i 2013. Det paradoksale med dette målet er at andelen med lavinntekt på Island, og i Norge, ble redusert i perioden etter finanskrisen. I Danmark, Sverige og Finland har det ikke skjedd store endringer etter finanskrisen, men ser en litt lengre tilbake har andelen med lavinntekt økt noe det siste tiåret.

Sosial ekskludering kan være vanskelig å operasjonalisere og måle. Lavinntekt er et mulig indirekte mål, en annen mulig tilnærming er å måle om husholdningene har tilstrekkelig med økonomiske ressurser til å delta aktivt. En subjektiv tilnærming til dette spørsmålet om husholdninger greier å få "endene til å møtes". I figur 4.5 ser vi andel husholdninger i Norden som har store problemer med dette. Her er det Island som først og fremst skiller seg ut. Mens mellom 2 og $4 \%$ av husholdningene i de andre landene rapporterer om problemer med å få endene til å møtes, var andelen på Island helt oppe i 12,8 \% i 2010, en betydelig økning etter finanskriseåret 2008, da andelen var 5,0 \%. Det er også over gjennomsnittet i hele EU og i Eurolandene. Også i 2004 var andelen i Island høy. I de andre nordiske landene er det lite spor etter finanskrisen på denne indikatoren.

Figur 4.5. Husholdninger som har store problemer med å få andelene til å møtes, 2004-2012. Prosent

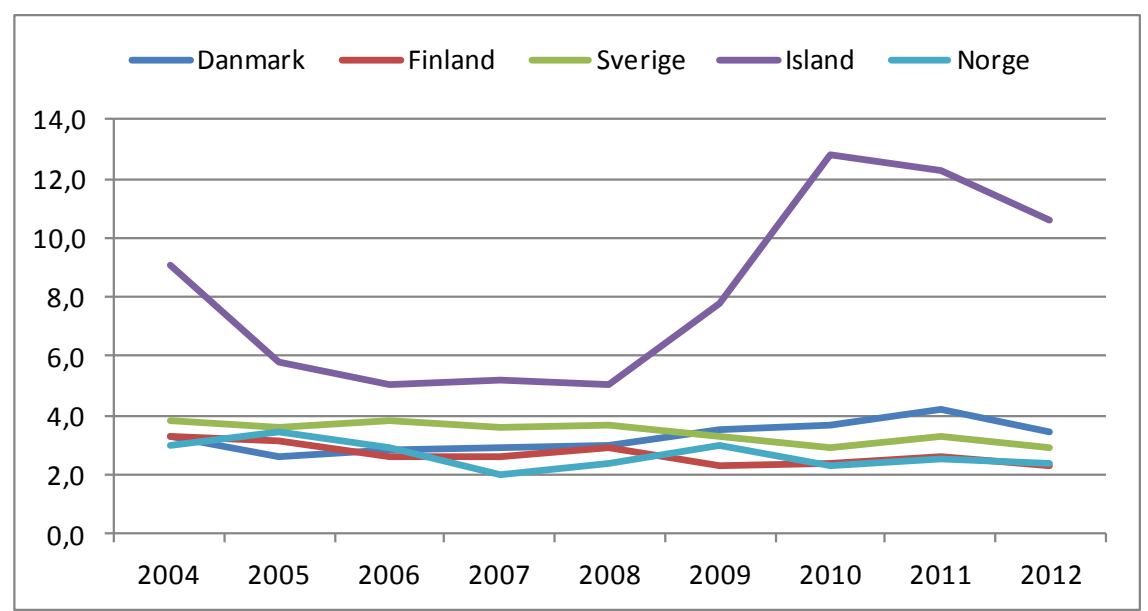

Kilde: Eurostat, SILC (06.06.2014). 
Et annet mål på tilstrekkelige ressurser er i hvilken grad husholdningene har en økonomisk buffer som gjør dem i stand til å dekke uforutsette utgifter.8 Figur 4.6 viser betydelig variasjon både mellom land og over tid i Norden. I 2012 var nivået høyest på Island (34,6 \%) og lavest i Norge (10,2 \%). Igjen ser det ut til å være et klart utslag av finanskrisen i Island, der andelen økte betydelig etter 2008. Også i Danmark var det en viss økning mot slutten av perioden, men ikke i samme grad. I Norge, Sverige og Finland har andelene til en viss grad stabilisert seg etter 2007.

Figur 4.6. Husholdninger som ikke er i stand til å dekke uforutsette utgifter, 2004-2012. Prosent

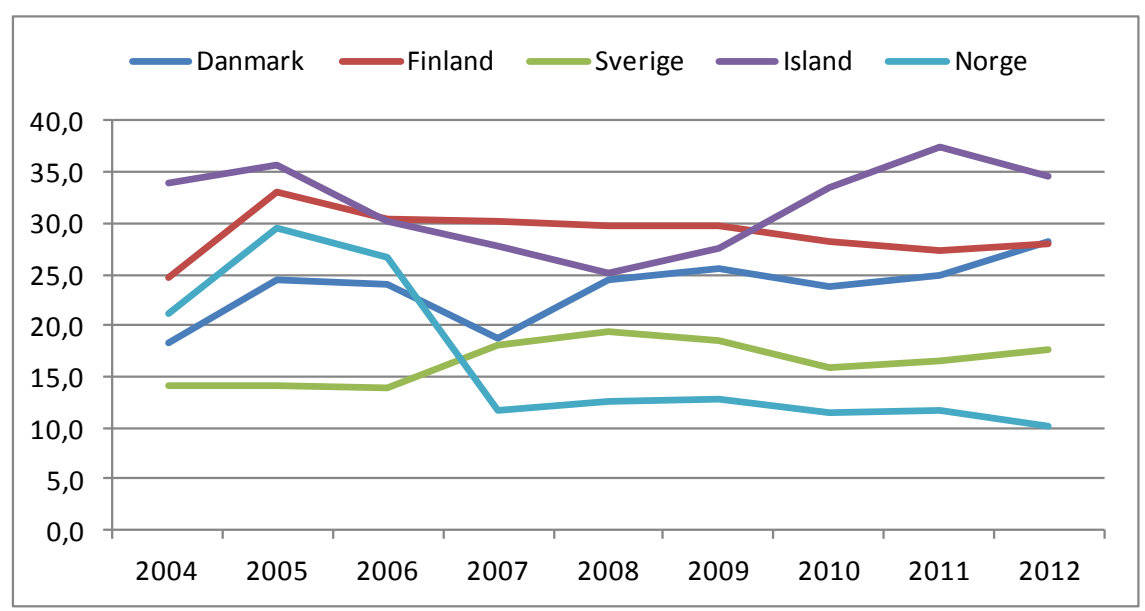

Kilde: Eurostat, SILC (06.06.2014).

\subsection{Noen grupper har større utfordringer}

Selv om det overordnede bildet vi får av tilknytning til arbeidsmarkedet og sosial deltakelse i Norden er positivt, viser det også at det er noen som faller utenfor.

\footnotetext{
${ }^{8}$ Den uforutsette utgiften er oppgitt å være et beløp omtrent tilsvarende månedlig disponibel inntekt som en enpersonhusholdning trenger for å komme over grensen for lavinntekt i henhold til EU60 målet.
} 


\subsubsection{Unge mer utsatt på arbeidsmarkedet}

Utviklingen i ungdomsledigheten (15-24 år) følger stort sett utviklingen i arbeidsledighet totalt, men nivåene er til dels betydelig høyere. I Sverige var ungdomsledigheten $23,6 \%$ i 2013, hele 15,6 prosentpoeng høyere enn den totale ledigheten (figur 4.7). Også i Finland er differansen stor, en ungdomsledighet på 19,9 \% i 2013 er 11,7 prosentpoeng over den totale. I de tre resterende nordiske landene er differansen mindre, mellom fem og seks prosentpoeng. Tallene tyder også på at ungdom er mer utsatt i krisetider, siden ungdomsledigheten relativt sett var høyest i de første årene av finanskrisen.

Figur 4.7. Arbeidsledige i alderen 15-24 år, 2003-2013. Prosent

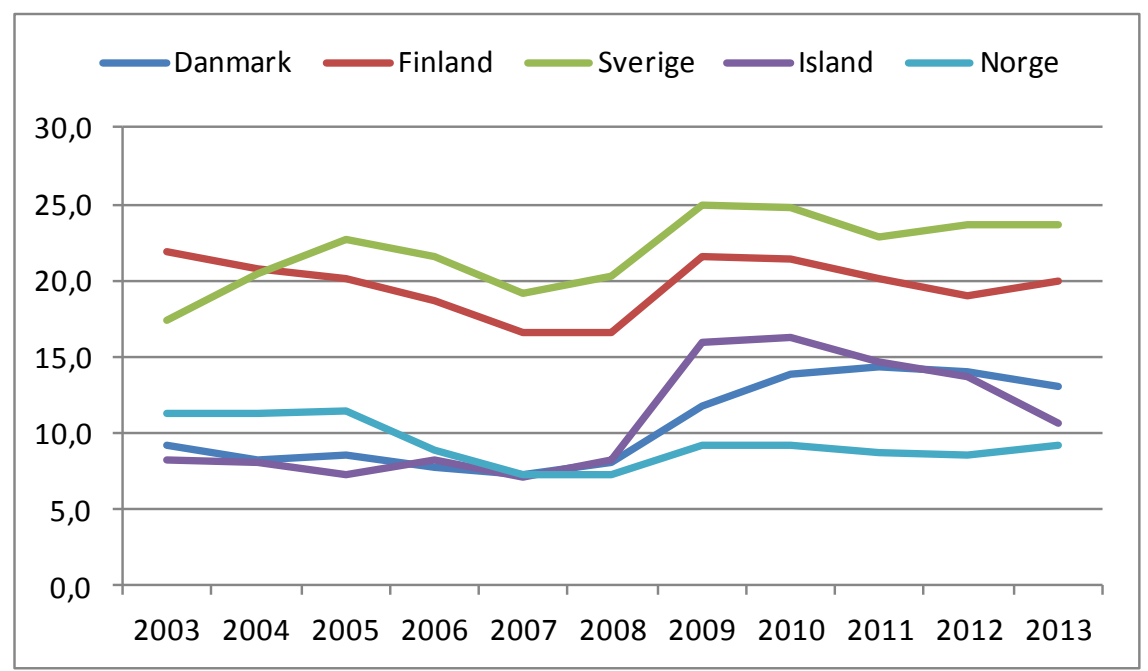

Kilde: Eurostat, LFS (04.06.2014).

Rapporten fra NOSOSKO 2013 peker også på at unge jevnt over har større fare for å være marginaliserte i arbeidsmarkedet enn det eldre har. Sammenhengen mellom ekskludering og alder ser ikke ut til å være like tydelig, men personer over 45 år har mindre fare for å være ekskluderte enn yngre. Det å være ufør eller ute av stand til å arbeide er et kjennetegn på utsatthet i seg selv, og faren for å ha dette kjennetegnet øker naturligvis med alder.

Når det gjelder fattigdom og sosial ekskludering, viser figur 4.8 at unge i alderen 16-24 år er mer utsatte enn andre aldersgrupper opp til 75 år. Andelen synker stort sett med alder frem til 74 år, for så å øke ganske betydelig. Dette er et hovedmønster som gjelder i alle nordiske land bortsett fra i Island, der andelen er høyest blant barn, for så å synke nokså jevnt med alder. 
Figur 4.8. Personer med risiko for fattigdom eller sosial ekskludering etter alder, 2012. Prosent

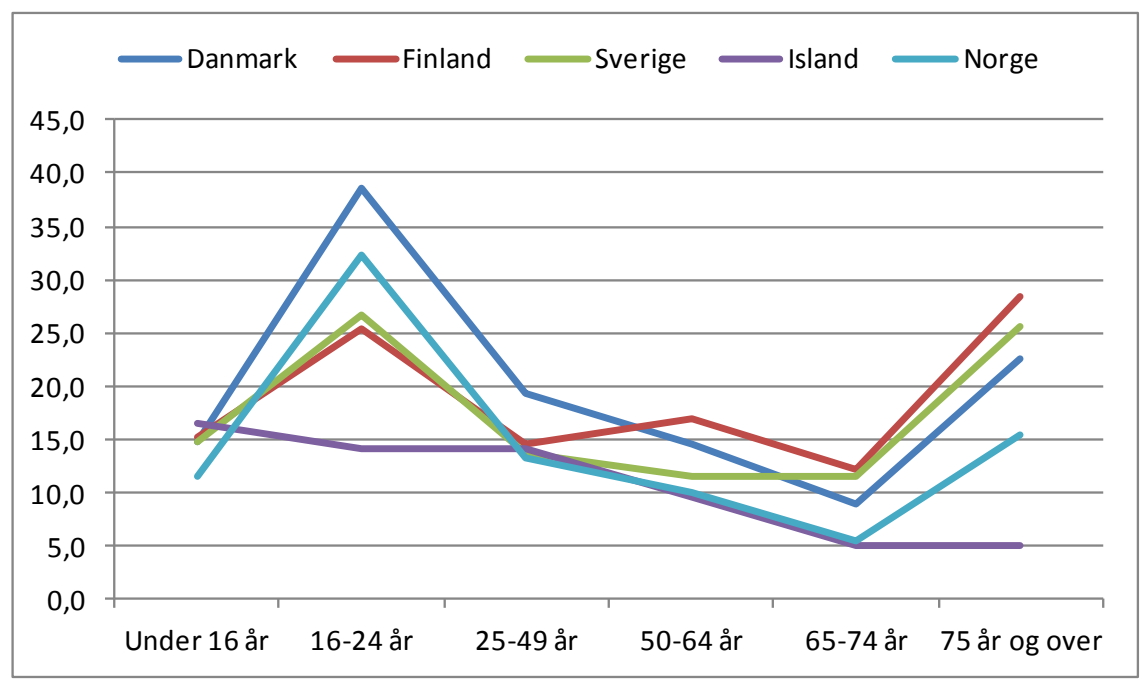

Kilde: Eurostat, SILC (06.06.2014).

Ser vi kun på delindikatoren for lavinntekt (EU60), så har den samme aldersprofil som hovedindikatoren. Ungdom i alderen 16-24 år og eldre på 75 år eller mer er mest utsatt.

Indikatorene som viser til evne til å få endene til å møtes eller klare en uforutsett utgift er indikatorer på husholdningsnivå, og ikke personnivå som de foregående. Enpersonhusholdninger rapporterer slike problemer ofte, og da vet vi også at andelen aleneboende er høyest blant de yngste og de eldste. Den gruppen som oftest rapporterer om denne typen $ø$ konomiske vanskeligheter er likevel enslige forsørgere.

\subsubsection{Svekket helse eller nedsatt funksjonsevne}

Et kjennetegn ofte forbundet med svakere tilknytning til arbeids- og samfunnsliv er nedsatt funksjonsevne. Dette kan operasjonaliseres og måles på ulike måter, oftest med en subjektiv tilnærming der personer selv vurderer sin egen funksjonsevne opp mot gitte kriterier. NOSOSKO rapporten fra 2013 viser også til at personer som vurderer sin egen helse som dårlig i langt mindre grad er yrkesaktive enn personer som vurderer sin egen helse som god. Det samme gjelder personer som har nedsatt funksjonsevne sammenlignet med personer som ikke har det. 
Nyere statistikk fra 2012 viser også at andelen med sterkt eller noe nedsatt funksjonsevne er langt høyere blant arbeidsledige og inaktive enn blant sysselsatte. Figuren under viser andel som har noen eller store begrensninger i hverdagsaktiviteter (nedsatt funksjonsevne) etter status på arbeidsmarkedet.

Figur 4.9. Andel personer 16-64 år med noen eller store begrensninger $\mathrm{i}$ hverdagsaktiviteter, etter status på arbeidsmarkedet, 2012. Prosent

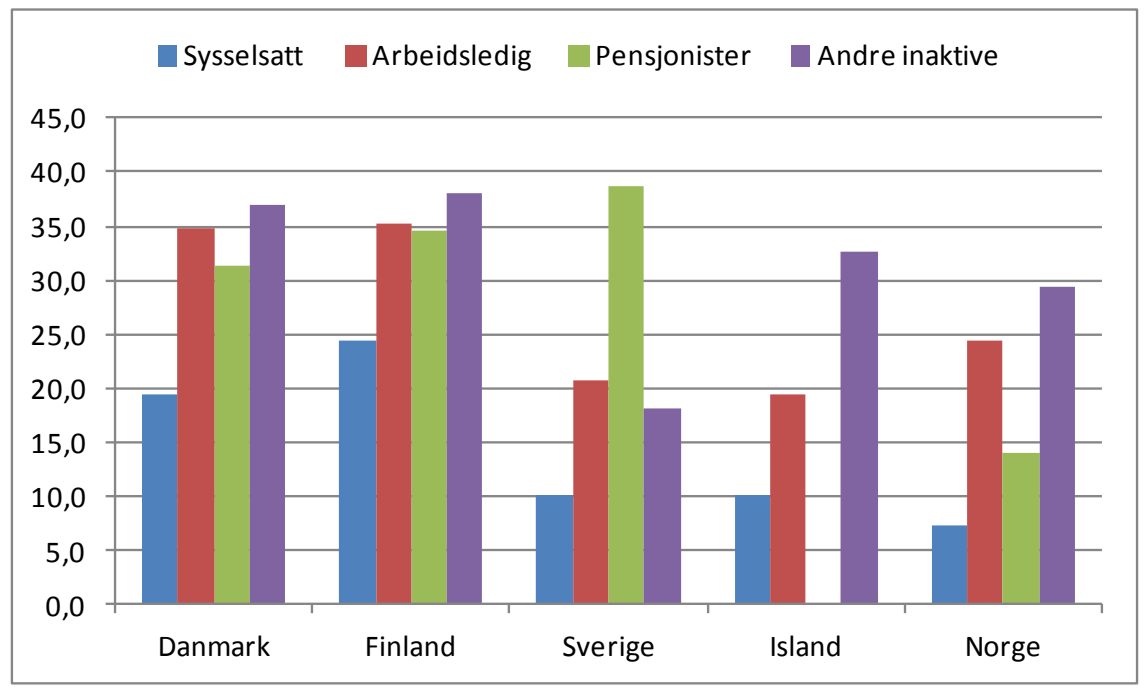

Kilde: Eurostat, SILC (06.06.2014).

Her er det også viktig å merke seg at det er en samspilleffekt mellom helse og utdanning. Svekket helse, eller nedsatt funksjonsevne, har sterkere negativ betydning for yrkesaktiviteten til dem med lav utdanning sammenlignet med dem med høy utdanning.

\subsubsection{Lav utdanning}

I et moderne og spesialisert arbeidsmarked som det nordiske er utdanning sentralt for å sikre en stabil tilknytning til arbeidslivet. Arbeidslivet stiller krav om formell kompetanse, og historisk sett har det vært en vridning fra utdanning og kvalifisering gjennom yrkesaktivitet til gjennom utdanningsinstitusjoner. Norden er en region med relativt høy gjennomsnittlig utdanning, men en skal likevel være oppmerksom på grupper med manglende formell kompetanse på grunn av at de ikke har gjennomført utdanning.

Figur 4.10 viser at personer med lav utdanning i langt større grad enn andre bor i husholdninger der det arbeides lite, mens figur 11 viser 
at andelen som lever i risiko for fattigdom eller sosial ekskludering også er klart fallende med økende utdanning.

Figur 4.10. Personer 18-59 år i husholdninger med lav arbeidsintensitet, etter utdanning, 2012. Prosent

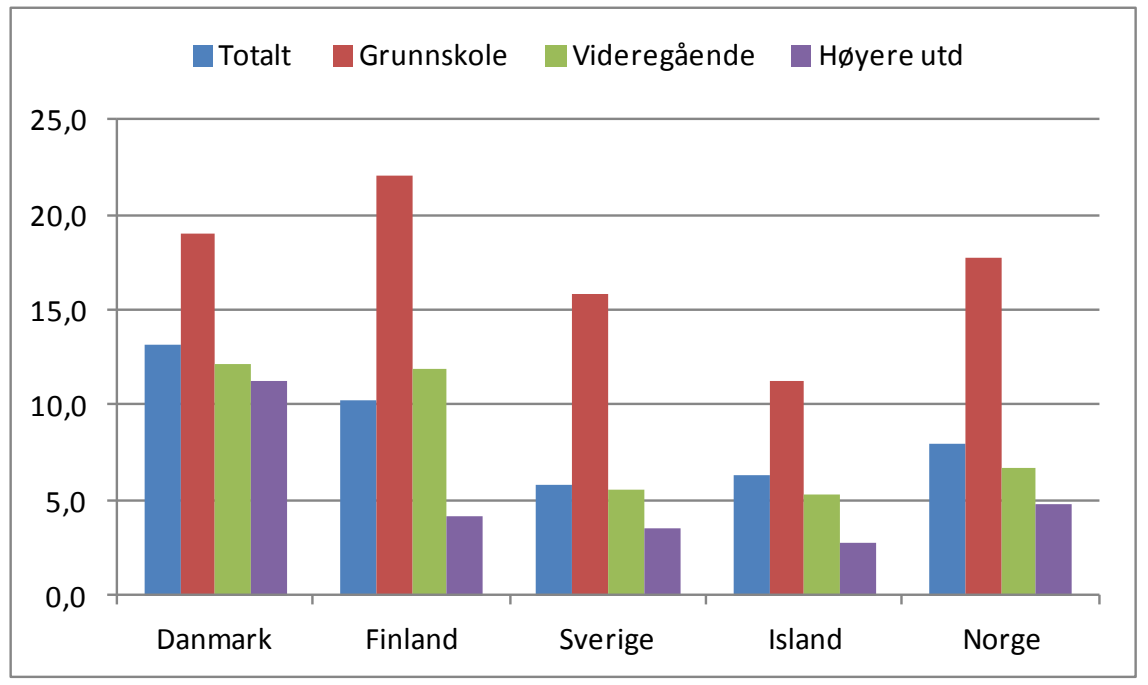

Kilde: Eurostat, SILC (06.06.2014).

Figur 4.11. Personer 18-59 år med risiko for fattigdom eller sosial ekskludering, etter utdanning, 2012. Prosent

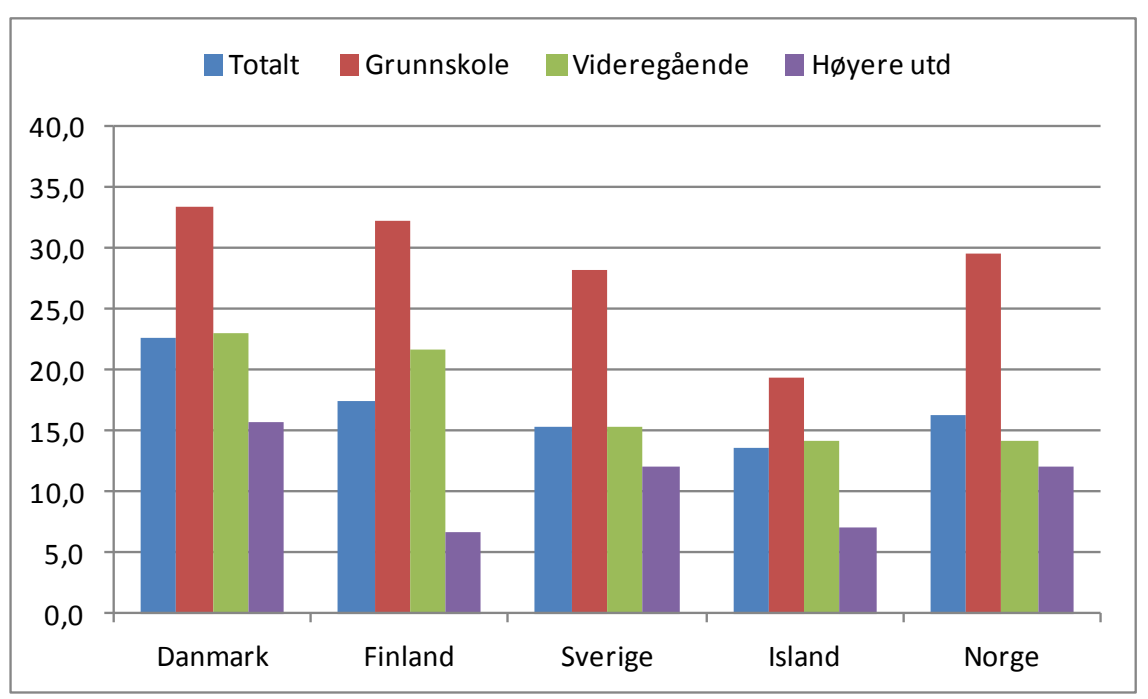

Kilde: Eurostat, SILC (06.06.2014). 


\subsubsection{Innvandrere}

Innvandrere, og da spesielt innvandrere fra utenfor EU/EØS området, har oftere enn andre svak tilknytning til arbeidsmarkedet og samfunnsliv. Komparativ statistikk på dette feltet tar som oftest utgangspunkt i fødeland, men gir likevel gode indikasjoner på at innvandrere er en utsatt gruppe. ${ }^{9}$ Vi har her tatt med to indikatorer som eksempler, arbeidsledighet og risiko for fattigdom eller sosial ekskludering (figur $4.12 \mathrm{og}$ 4.13). Begge indikatorene viser at personer født utenfor det aktuelle landet generelt er mer utsatt enn de som er født i landet. I figur 4.13 skiller vi også mellom personer født innenfor eller utenfor EU-området, noe som synliggjør at personer født utenfor EU området er spesielt utsatte. Dette gjelder i alle nordiske land.

Figur 4.12. Arbeidsledige i alderen 15-64 år, etter fødeland, 2013. Prosent

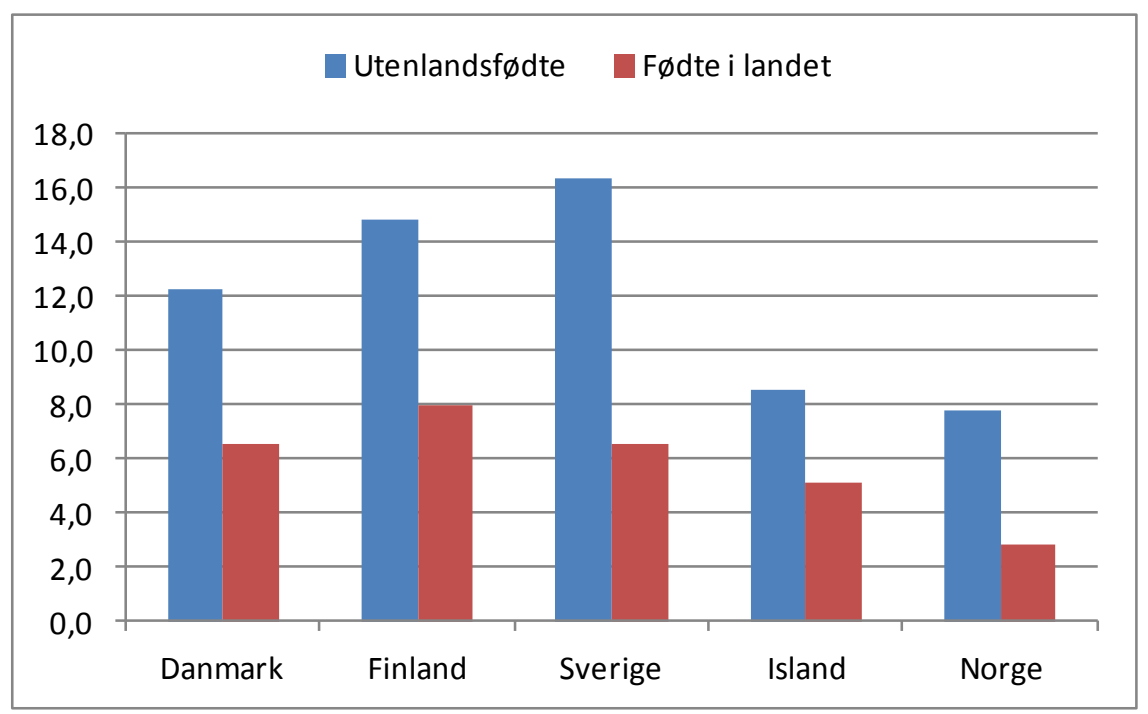

Kilde: Eurostat, LFS (04.06.2014).

\footnotetext{
9 Det å være født i et annet land betyr ikke nødvendigvis at man er innvandrer. I Norge er kriteriet for å regnes som innvandre at man selv er født i utlandet av to utenland skfødte foreldre. Personer født i landet av to utenlandskfødte regnes ikke som innvandrere, og vil selvfølgelig heller ikke dekkes av kategorien "utenlandskfødte".
} 
Figur 4.13. Personer 18 år og over med risiko for fattigdom eller sosial ekskludering, etter fødeland, 2012. Prosent

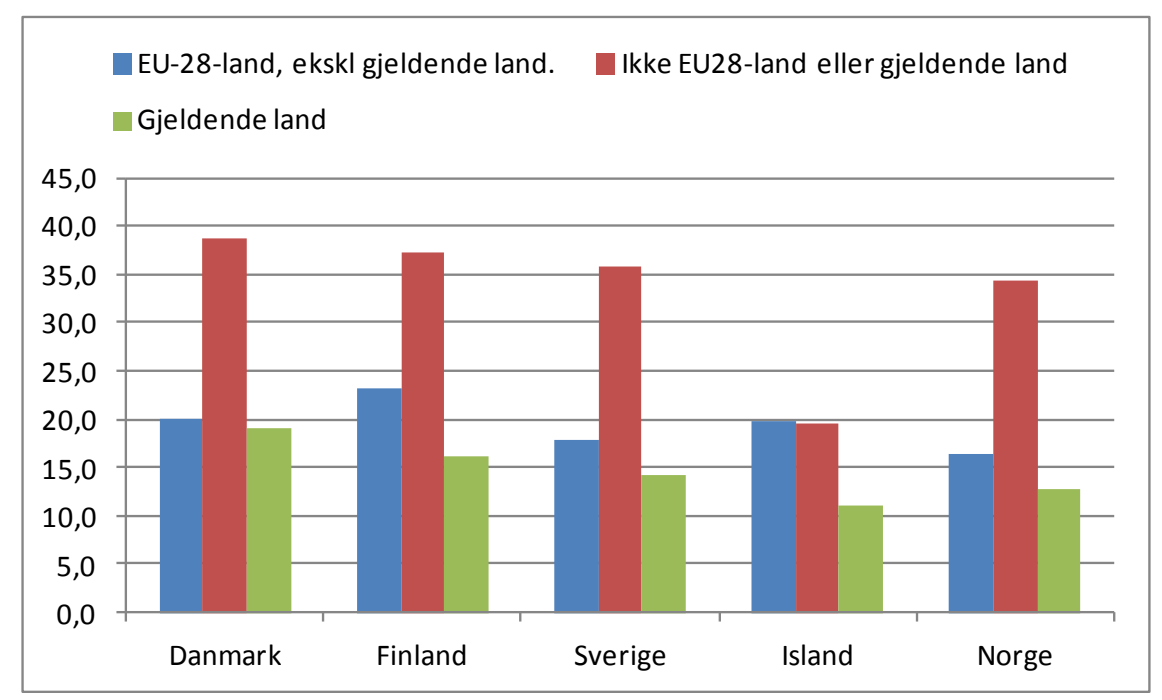

Kilde: Eurostat, SILC (06.06.2014).

\subsubsection{Spesielt utsatte grupper}

Kombinasjoner av ulike kjennetegn forbundet med risiko for å stå utenfor arbeids- og samfunnsliv vil være ekstra uheldig. Det er imidlertid små grupper som sjelden lar seg identifisere i offisiell statistikk, og spesielt ikke i komparativ statistikk. Det betyr likevel ikke at det ikke er av stor interesse å forsøke å kartlegge og følge disse gruppene over tid.

En rapport basert på en intervjuundersøkelse blant innsatte i norske fengsler fra 2004 (Friestad og Hansen 2004) slår fast at innsatte i fengsler har en svak posisjon på arbeidsmarkedet og svak personlig økonomi. Innsatte rapporterte også om kombinasjon av ulike problemer som rus, psykiske problemer og bostedsløshet. Denne formen for hopning av levekårsproblemer blant innsatte er neppe unik for Norge. En svensk studie (Nilsson 2003) viser at levekårsproblemer knyttet til utdanning og yrkesaktivitet, og fremfor alt hopning av levekårsproblemer, er sterkt korrelert med fare for tilbakefall til kriminalitet. Noe av det samme understrekes av en norsk studie som viser at arbeidstilknytning etter soning bidrar til betydelig redusert risiko for tilbakefall (Skardhamar og Telle 2009).

I en studie fra Island rapporteres det samme, de innsattte hadde ulike psykiske problemer og rusmiddelproblemer og en stor andel hadde ADHD (Guðjónsson et. Al 2008).

Europeisk overvåkingssenter for narkotika og narkotikamisbruk (EONN) sin årsrapport for 2003 peker på noe av de samme faktorene 
når det gjelder rusmisbrukere (http://annualreport.emcdda.eu.int.). De har en utsatt sosiale posisjon med klare tendenser til hopning av levekårsproblemer. Faktorer forbundet med rusmisbruk er lav utdanning, tidlig avsluttet eller avbrutt skolegang, svak tilknytning til arbeidsmarkedet, utsatthet på boligmarkedet, samt høy sykelighet (herunder psykisk sykdom) og dødelighet. I tillegg til dette kommer sosiale stigma knyttet til å være rusmisbruker.

\subsection{Innsats for å inkludere utsatte grupper i arbeid og samfunnsliv}

Alle de nordiske landene har en relativt omfattende arbeidsmarkeds- og sosialpolitikk for å møte disse utfordringene. Et fellestrekk som ofte nevnes for den nordiske velferdsmodellen er universelle ordninger som skal bidra til å få folk i arbeid og bekjempe fattigdom. Offentlig politikk og tiltak ligger imidlertid utenfor rammen av denne rapporten. ${ }^{10}$

Det finnes også i de nordiske landene en rekke andre aktører og initiativ rettet mot disse utfordringene.

Initiativene retter seg ofte mot grupper som er særlig utsatte og som står, eller er i fare for å havne, lengst fra det ordinære arbeidsmarkedet og i en tilstand betegnet som sosialt ekskludert. Dette kan være psykisk syke, personer med rusproblemer, tidligere innsatte i fengsler, ungdom med sammensatte problemer, innvandrere med spesielle integreringsutfordringer eller andre spesielt utsatte grupper. Grupper som vi vet befinner seg i en svært sosialt utsatt posisjon, både med hensynet til arbeidsmarkedet og annen sosial aktivitet.

Denne rapporten handler om innsatser som legger til rette for initiativ og aktivitet på dette feltet som kan plasseres under begrepene sosialt entreprenørskap og sosial innovasjon. Dette omtales nærmere senere i rapporten.

\footnotetext{
${ }^{10}$ For mer informasjon om dette kan vi for eksempel vise til arbeidet som gjøres i Nordisk Medisinstatistisk Komité (NOMESKO) og Nordisk Sosialstatistisk Komité (NOSOSKO): http://www.nowbase.dk/
} 

Del 3

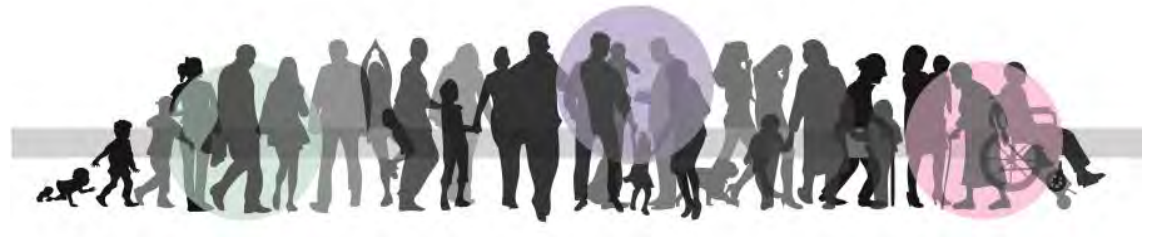





\section{A}

\section{Innsatser for å legge til rette for sosialt entreprenørskap og sosial innovasjon i de nordiske landene}

I dette kapitlet presenterer vi det samlede nordiske materialet fra den gjennomførte kartleggingen. Presentasjon bygger på landrapporter for hvert land som følger i de neste kapitlene.

Men først, kort om det metodiske opplegget for kartleggingen.

\subsection{Metodisk opplegg}

Vi har i denne kartleggingen valgt å definere begrepet innsats som "rammebetingelser, virkemidler, tiltak og aktiviteter". Med begrepet "å legge til rette" forstår vi å bidra til at et ønsket mål nås, i dette tilfelle sosialt entreprenørskap og sosial innovasjon i arbeidet for å inkludere utsatte grupper i arbeid og samfunnsliv.

\subsubsection{Utvalg}

For å få tilgang til informasjon om innsatser, har vi innhentet data fra aktører som har ansvar for og arbeider med innsatser innenfor kartleggingsområdet. Vi kunne ha ønsket å supplere disse dataene med data fra mottakerne/brukerne av innsatsene. Det har ikke vært mulig innenfor rammen av denne kartleggingen.

Ingen av de nordiske landene har noen form for register eller annen dokumentasjon over aktører og innsatser for å legge til rette for sosialt entreprenørskap og sosial innovasjon. Valg av respondenter har derfor skjedd ved at hvert lands medlemmer i arbeidsgruppen har utarbeidet 
en respondentliste med utgangspunkt i egen kunnskap om feltet, nettverk og nettsøk. ${ }^{11} \mathrm{Vi}$ åpnet også opp for at respondentene som deltok, kunne foreslå andre respondenter, eller trekke seg fra undersøkelsen dersom de vurderte egen aktivitet eller virksomhet som ikke relevant.

Et spørsmål i arbeidet med respondentlistene var hvor vi skulle sette grensen for hvilke aktører og innsatser som skulle tas med, og hvilke som skulle holdes utenfor.

Arbeidsgruppens gjennomgang av begrepene sosialt entreprenørskap og sosial innovasjon, se kapittel 1, viste at det i de fem landene benyttes flere ulike begreper som delvis, men ikke helt, overlapper hverandre og forståelsen som er gitt i mandatet. Vi vurderte det derfor som mest hensiktsmessig å velge en åpen tilnærming til hvilke aktører som skulle inkluderes i kartleggingen, se vedlegg 2 .

Vi har i henhold til mandatet for arbeidet ikke forsøkt å finne fram til og kartlegge (absolutt) alle innsatser, men å synliggjøre bredde og variasjon i innsatser innenfor ulike sektorer. Det er likevel viktig for oss å presisere at vi kan ha gjort valg underveis som har bidratt til at vi ikke har fanget opp bredden og variasjonen av innsatser i de ulike landene, og at variasjoner mellom landene kan skyldes ulike valg i arbeidet med respondentlistene heller enn variasjon i den faktiske situasjonen.

Vi sendte ut et spørreskjema til i alt 193 respondenter, og fikk inn 131 svar, dvs. fra om lag 2/3 av de inviterte. Andelen som svarte, varierer noe mellom landene, fra overkant av åtte av ti for Sverige og Danmark, til om lag syv av 10 for Norge og Island, og en av tre for Finland.

Vi har ingen sikker kunnskap om hvorfor noen har valgt å ikke delta.

Vi skulle gjerne ha hatt med svar fra alle de inviterte til kartleggingen.

Vår vurdering er likevel at utvalget samlet sett inneholder en bredde og variasjon i forhold til de områdene som er nevnt i mandatet, sektortilhørighet og type innsats.

\subsubsection{Innsamling av data}

Informasjon om innsatsene er samlet inn ved hjelp av et spørreskjema med en kombinasjon av strukturerte og åpne spørsmål, med vekt på åpne spørsmål.

11 Vi har også sendt ut spørreskjema til aktører som har Norden som sitt nedslagsfelt. Dette er to respondenter hvorav èn ble lagt til listen til Danmark og èn til listen til Norge I tillegg ble respondenter som deltok i uttesting av spørreskjemaet, gitt mulighet til å foreslå andre. 
Et forslag til spørreskjema ble testet på tre-fem respondenter i hvert land. Det endelige spørreskjemaet ble oversatt til dansk, svensk, islandsk og finsk, og alle land ble gitt mulighet for å svare på eget språk.

Et spørsmål i arbeidet med spørreskjemaet var hvordan vi kunne gi mulighet for respondentene til å beskrive innsatser av mer sammensatt karakter. Vi visste ut fra vår kjennskap til feltet, at flere aktører ikke bare har ansvar for èn, men flere innsatser, og at flere innsatser også kan bestå av flere delelementer eller aktiviteter. Vi forsøkte gjennom utformingen av spørreskjemaet å gi mulighet for å beskrive et slikt sammensatt bildet, men ser av svarene at det kan ha rådet noe uklarhet om hvordan dette kunne gjøres.

Et annet spørsmål var hvordan sikre og felles forståelse av alle begrepene som benyttes. Vi ser av svarene at respondentene flere steder har oppfattet begreper og derved spørsmål på ulike måter. Det gjelder blant annet begrepene "målgruppeinvolvering" og "bærekraft".

\subsubsection{Gjennomføring og behandling av data}

Vi benyttet et webbasert spørreskjemaverktøy. Et invitasjonsbrev med lenke til spørreskjemaet ble sendt ut på e-post fra arbeidsgruppens medlemmer til respondenter i eget land. Hvert land fulgte også opp med påminnelse i to runder til de som ikke svarte innen oppsatt frist.

Invitasjonen gikk til organisasjonen/institusjonen/virksomheten. Det ble benyttet e-postadresser til enkeltpersoner som arbeider med det aktuelle saksfeltet, der navn på disse var kjent, og e-postadressser vi fant på nettet, der vi ikke hadde informasjon om dette.

Vi informerte i invitasjonen om at det var opp til hver organisasjon/institusjon/virksomhet å avgjøre hvem som skulle svare på spørreskjemaet, og respondentene ble bedt om å angi rolle i organisasjonen for den som hadde svart.

Det går fram av svarene at i 62 tilfeller er spørreskjemaet fylt ut av leder, i 52 tilfeller av ansatte, i ni tilfeller av eier og i åtte tilfeller av andre.

Spørreverktøy ble administrert av sekretariatet i Norge som også lagde exelfiler med tabeller og tekst fra de åpne spørsmålene.

Hvert enkelt land har gjennomgått data for eget land og utarbeidet landrapportene etter en felles hovedstruktur. Basert på disse landrapportene, er det utarbeidet en fellesrapport for det samlede datamateriale. Vi vil peke på at materialet i den enkelte landrapport kan være tolket ulikt.

Det følger av mandatet at kartleggingen skal være av deskriptiv karakter. Arbeidsgruppen skal i rapporten kun gi en beskrivelse, ikke en vurdering av de ulike innsatsene. Vi har latt dette være retningsgivende 
for vårt arbeid. I rapporten presenteres innsatsene slik de er beskrevet i svarene fra respondentene.

Vi henviser til en rekke nettsider der respondentene selv har oppgitt disse. I tillegg benytter vi utsagn og eksempler direkte fra kartleggingsmaterialet. Dette er avklart med de aktuelle respondenter.

Det har vært en rekke utfordringer i arbeidet med å utforme et godt metodisk opplegg for kartlegging av et område som kjennetegnes ved at det ikke finnes en felles etablert begrepsbruk i de nordiske landene.

Vår vurdering er at kartleggingen likevel er egnet til å gi et lite innblikk i et felt som i nordisk sammenheng er relativt nytt.

\subsection{Samlet om innsatser i de nordiske landene}

Innledningsvis vil vi peke på at arbeid for å legge til rette for inkludering av utsatte grupper i arbeid og samfunnsliv er et viktig kjennetegn ved de nordiske velferdsstatene. Slik sett kan alle land vise til omfattende innsatser for dette. Et annet kjennetegn er partssamarbeidet i arbeidslivet. Den nordiske velferdsstatene er også kjennetegnet av en aktiv tredje sektor. Det faller utenfor arbeidsgruppens mandat å fange opp dette svært betydningsfulle og omfattende nett av innsatser. Vårt kartleggingsområde er innsatser som legger til rette for sosialt entreprenørskap og sosiale innovasjon i arbeidet med å inkludere utsatte grupper i arbeid og samfunnsliv.

Vårt inntrykk i forkant av kartleggingen var at dette er et forholdsvis nytt område Norden, og at det til dels også varierer mellom de ulike landene hvilke innsatser som finnes. Kartleggingen etterlater et tilsvarende inntrykk. Et fellestrekk ved det nordiske materialet er at de fleste innsatser som er direkte rettet mot sosialt entreprenørskap og sosiale innovasjon i arbeidet for å inkludere utsatte grupper i arbeid og samfunnsliv, er av nyere dato. Vårt inntrykk er at innsatser for å legge til rette for sosiale virksomheter, eksisterte før vi fikk oppmerksomhet om sosialt entreprenørskap og sosial innovasjon. Landrapportene fra Finland og Island viser at sosialt entreprenørskap og sosial innovasjon så langt ikke er begreper eller betegnelser som anvendes i særlig grad i disse landene. Det er likevel slik at flere innsatser for entreprenørskap og innovasjon generelt, også kan bidra til å fremme sosialt entreprenørskap og sosial innovasjon, slik det pekes på i den islandske landrapporten.

Et viktig trekk ved vårt materiale er ulik bruk av begreper. I det danske materialet finner vi for eksempel begrepet "sosialøkonomiske virksomheter", i det svenske materialet begreper som "sosiale foretak", "arbeidsin- 
tegrerende foretak" og "samfunnsentreprenørskap". Det fremgår av landrapporten fra Finland at begrepet "sosialt entreprenørskap" sjelden benyttes, men at virksomheter som betegnes "sosiale foretak" eller "samfunnsentreprenørskap", likner virksomheter som betegnes som "sosialt entreprenørskap". Island viser i sin landrapport til at begrepene "sosialt entreprenørskap" og "sosial innovasjon" ikke er særlig kjent verken i fag, felt eller politikk. I det norske materialet finner vi flere ulike begreper.

Ulik bruk av begreper er noe som kan prege både vårt utvalg og respondentenes svar. Vi kommer nærmere tilbake til dette i våre anbefalinger.

Vi starter med å gi en samlet oversikt over respondentene, før vi beskriver hvilke hovedtyper av innsatser som er kartlagt. Dernest tar vi for oss hvordan innsatsene er finansiert. Etter dette ser vi på hva som er formål og målgruppe for innsatsene. Her ser vi særlig hen til om innsatsene har som mål å legge til rette for sosialt entreprenørskap og/eller sosial innovasjon og om de er spesielt rettet mot å inkludere utsatte grupper i arbeid og samfunnsliv eller har en bredere relevans. Etter dette gjennomgår vi hvordan innsatsene legger til rette og i hvilken grad innsatsene fokuserer på de fire kjennetegnene ved sosialt entreprenørskap som arbeidsgruppen har vektlagt. Vi oppsummerer også respondentenes svar på spørsmål om de viktigste hindre og behov for nye innsatser for sosialt entreprenørskap og sosial innovasjon i arbeidet for å inkludere utsatte grupper i arbeid og samfunnsliv i eget land.

\subsubsection{Respondentene}

Det ble sendt ut spørreskjema til i alt 193 respondenter. Av disse fikk vi inn 131 svar. Det vises til den enkelte landrapport for antall respondenter i det enkelte land.

Hovedtyngden av respondentene befinner seg i offentlig eller tredje sektor. Om lag en femtedel befinner seg i privat sektor. 
Figur. 5.1. Sektor ${ }^{12}$

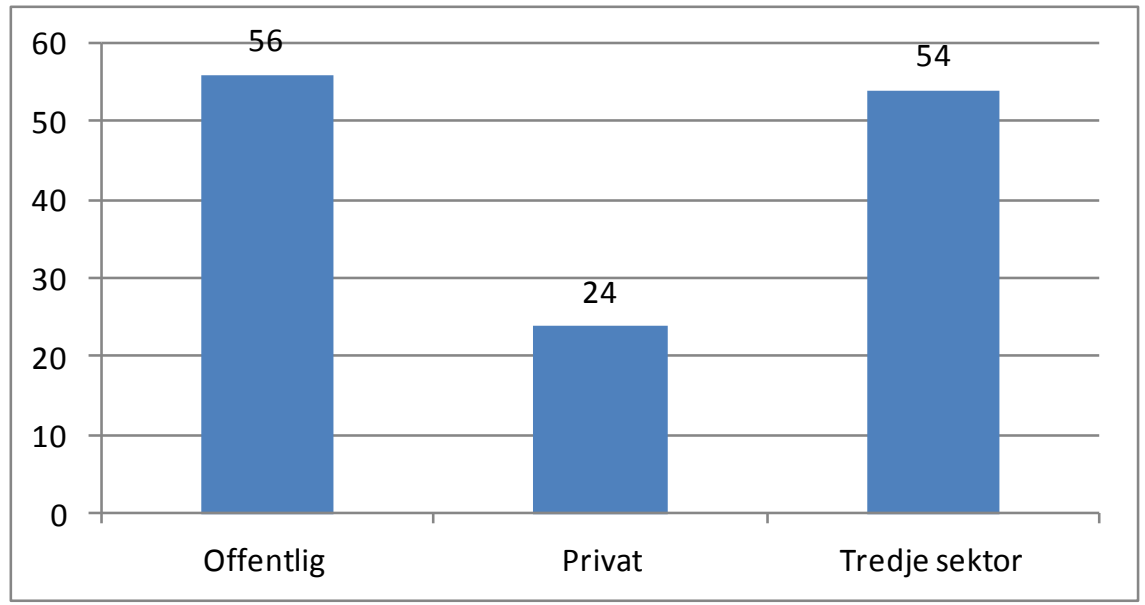

Det varierer mellom landene hvilken sektor man har flest respondenter fra. I de svenske og finske dataene er det flest fra tredje sektor, i de norske flest fra offentlig sektor. Danmark har om lag like mange respondenter fra offentlig sektor og tredje sektor. Island har flest respondenter fra offentlig sektor, men også en respondentgruppe som i noen grad skiller seg ut fra de øvrige land, hvilket omtales på følgende måte i landrapporten:

Siden det i Island ikke er vanlig å bruke begrepene sosiale entreprenør eller sosial innovasjon, var det vanskelig å finne aktører som kun yter støtte til sosiale entreprenører eller som bruker dette begrepet. Spørreskjemaet ble derfor sendt til aktører som gir støtte til entreprenører generelt, inkludert sosiale entreprenører.

Alle land har færrest respondenter fra privat sektor.

\subsubsection{Hvilke typer innsatser er kartlagt?}

I mange tilfeller vil innsatser som fremmer sosialt entreprenørskap være de samme som fremmer annen form for entreprenørskap. Tilsvarende vil innsatser som fremmer innovasjon generelt, også kunne være de samme som fremmer sosial innovasjon spesielt. Innsatser som utdanning og finansiering, er kjente eksempler på tilrettelegging for utvikling generelt.

12 Det totale antall respondenter er her 133, da to respondenter har krysset av for både privat og tredje sektor. 
Arbeidsgruppen forhåndskategoriserte en rekke innsatstyper basert på kunnskapen vi hadde om temaet og eksemplene som fremgikk av mandatet. I tillegg ga vi respondentene mulighet for å nedtegne eventuelle andre typer av innsatser, dersom de hadde det. Respondentene kunne krysse av flere innsatstyper. Vi finner følgende fordeling i det nordiske materialet:

Figur 5.2. Innsatstyper

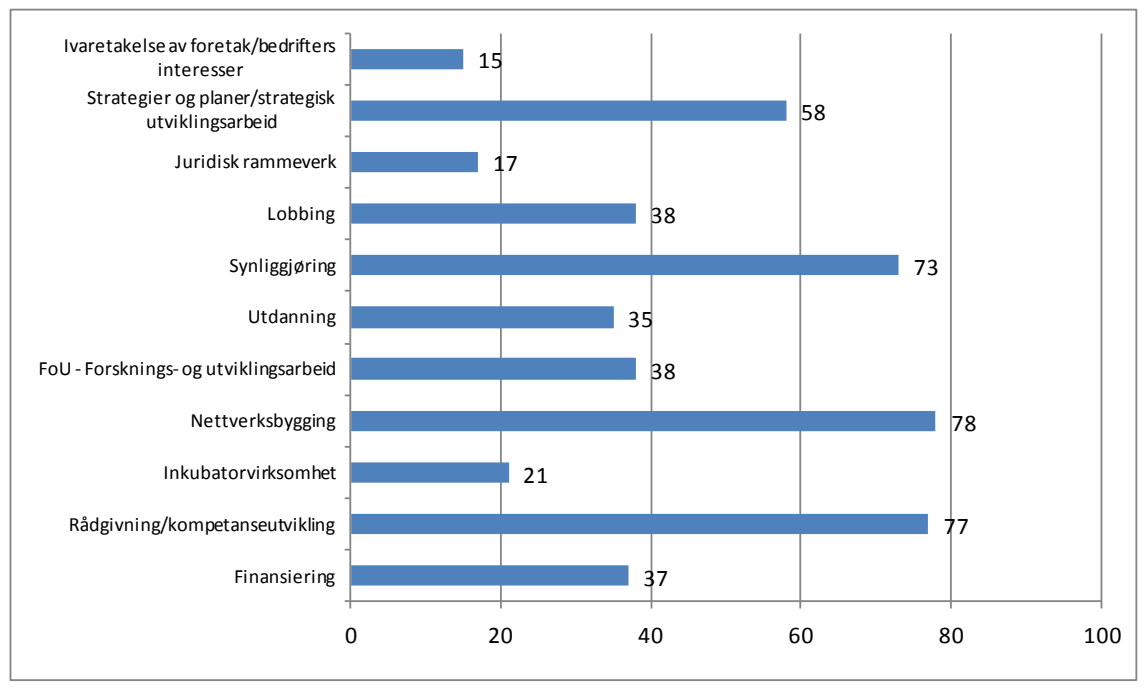

Alle respondenter har krysset av for minst to typer av innsatser, de fleste for flere enn to, og noen har svart at de tilbyr alle typer innsatser. I det nordiske materialet er det flest eksempler på rådgivning/ kompetanseutvikling, synliggjøring og nettverksbygging. Juridisk rammeverk og ivaretakelse av foretaks/bedrifters interesser er minst utbredt. Når det gjelder finansiering har 37 av 131 svart at de tilbyr denne form for tilrettelegging.

Bak dette mer overordnede bildet, skjuler det seg en god del variasjon mellom landene. Det gjelder blant annet hvor mange innsatser som er kartlagt innenfor hver kategori og ulike kjennetegn ved innsatsene. Bak et svar kan det skjule seg aktører både med lang og omfattende virksomhet på feltet og mindre aktører som nylig har startet opp. Svarene på de åpne spørsmålene gir noen indikasjoner på dette. For eksempel ser vi at utdanning og forskning er et område som Danmark har arbeidet med over flere år, mens synliggjøring er en innsatstype som den svenske landrapporten viser at det er satset mye på.

Ved gjennomgang av de åpne spørsmålene finner vi også at de fleste tilretteleggerne har noen hovedinnsatser, som følges opp av innsatser som skal bidra til å understøtte hovedinnsatsen. For eksempel ser vi at 
finansiering som innsats ofte følges av ulike former for kurs, konferanser og rådgivning, som skal bidra til å fremme målet med finansieringen. Denne form for hovedinnsats og støtteinnsatser er et relativt gjennomgående trekk i alle land. Vi ser også at inkubasjonsvirksomhet i flere tilfeller er ment å fremme muligheten for finansiering og nettverksbygging. Tilsvarende ser vi at rådgivning er ment å fremme nettverksbygging og å ivareta foretaks/bedrifters interesser og bærekraft.

\subsubsection{Hvordan er innsatsene finansiert?}

Offentlige midler framstår som finansieringskilde for minst halvparten av de tilretteleggende innsatsene, noe som også må ses i sammenheng med at en stor andel av innsatsene befinner seg i offentlig sektor.

Det er samtidig noe usikkerhet knyttet til svarene på dette spørsmålet, da respondentene pga. en teknisk feil kun fikk mulighet for å krysse av for ett svaralternativ på spørreskjemaet. Den høye andelen "annet" må forstås i lys av dette. Respondentene som krysset av her beskriver en rekke ulike finansieringskilder som salg av tjenester, bruk av egne midler, næringslivssponsing (ikke investering), bruk av egen privat tid, bruk av arbeidstid som "gis" til den aktuelle innsatsen, bytte av tjenester og pro-bono tjenester. Her beskrives også i flere tilfeller en kombinasjon av ulike finansieringskilder.

Den finske landrapporten påpeker følgende når det gjelder finansiering:

Innsatsene finansieres gjennom flere finansieringskilder, men i hovedsak gjennom å kombinere ulike (offentlige) finansieringskilder: Bidrag, støtte, serviceavtaler og Eurepeiska Socialfonden (ESF) prosjektfinansiering, men delvis også i form av betaling fra brukere av innsatsene. Ut fra svarene har det ennå ikke i høy grad utviklet seg et marked for private investorer eller fond i Finland. 
Figur 5.3. Finansieringskilder

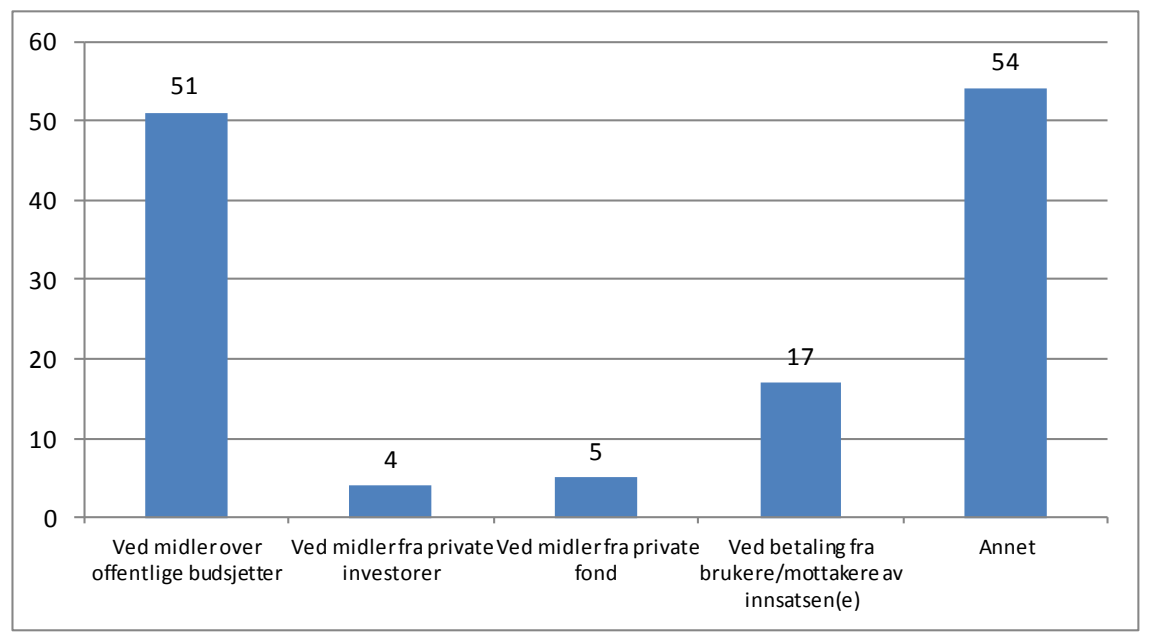

Det er et relativt lavt antall innsatser som finansieres ved private midler, men det finnes en del eksempler på ulike typer private midler i "annet kategorien". Den svenske landrapporten viser at man i denne kategorien finner både offentlige midler, private midler og fond.

\subsubsection{Hva er formål og målgruppe for innsatsene}

Det følger av mandatet for arbeidsgruppen at kartleggingen skal omhandle innsatser som legger til rette for sosialt entreprenørskap og sosial innovasjon rettet mot utsatte grupper i arbeid og samfunnsliv. Vi valgte likevel en bred tilnærming til kartleggingen, slik vi tidligere har redegjort for. Dette har bidratt til at vi også har samlet inn informasjon som kan belyse området sosialt entreprenørskap og sosial innovasjon mer generelt.

Generelt viser kartleggingen at formål og målgruppe for innsatsene, er på et forholdsvis overordnet nivå. Det er i noen tilfeller formulert formulert klare mål og målgrupper. I det videre gjennomgår vi materialet med utgangspunkt i følgende to hovedkategorier:

- Innsats for å legge til rette for sosialt entreprenørskap og sosial innovasjon i arbeidet for å inkludere utsatte grupper i arbeid og samfunnsliv.

- Innsats for å legge til rette for sosialt entreprenørskap og sosial innovasjon generelt. 


\section{Innsatser for å legge til rette for sosialt entreprenørskap og sosial innovasjon i arbeidet for å inkludere utsatte grupper i arbeid og samfunnsliv}

I det samlede nordiske materialet er det kartlagt relativt få eksempler på innsatser som respondentene beskriver som direkte rettet mot sosialt entreprenørskap og sosial innovasjon i arbeidet for å inkludere utsatte grupper i arbeidsmarkedet spesielt. Vi betrakter dette som et viktig og interessant funn, og vi spør oss om det faktisk er slik at det finnes få innsatser som har som som mål å legge til rette for disse områdene. En mulig forklaring er også at respondentene som er inkludert i kartleggingen, først og fremst arbeider med tematikken mer generelt enn rettet mot arbeid og inkludering spesielt. Vi vil i denne sammenheng peke på følgende kommentar i den islandske landrapporten, som nok har gyldighet for Norden generelt:

Et mindretall av respondentene svarer at de spesielt støtter integrering av ekskluderte grupper i samfunnslivet. Ingen av disse benytter begrepene sosialt entreprenørskap og sosial innovasjon i beskrivelsen av sin innsats, selv om innsatsene absolutt kan sies å legge til rette for dette i følge definisjoner i litteraturen.

Det er imidlertid noen respondenter som sier at målet med innsatsen er å legge til rette for sosialt entreprenørskap og sosial innovasjon i arbeidet for å inkludere utsatte grupper i arbeid og samfunnsliv spesielt. Blant disse viser Sverige blant til Inkludera Invest. ${ }^{13}$ I det danske materialet finner vi blant annet Social+, som arbeider med å:

fremme sosiale oppfinnelser som løser eller forebygger sosiale problemer for utsatte mennesker.

I det norske materialet finner vi blant annet en tilskuddsordning som forvaltes av Arbeids- og velferdsdirektoratet. Målet med denne ordningen er å stimulere til utvikling av sosialt entreprenørskap rettet mot bekjempelse av fattigdom og sosial eksklusjon i Norge. Finland og Island viser til at de verken anvender begrepene eller gjør koplinger mellom sosialt entreprenørskap og sosial innovasjon.

13 Inkludera invest, http://inkluderainvest.se 


\section{Innsats for å legge til rette for sosialt entreprenørskap og sosial innovasjon generelt}

Det samlede materialet etterlater et inntrykk av at vi finner flere innsatser med en generell innretning mot sosialt entreprenørskap og sosial innovasjon enn mot utsatte grupper i arbeid og samfunnsliv spesielt. Fra den danske landrapporten finner vi blant annet eksemplet DANISIC, som er en studentorganisasjon som arbeider med å spre kunnskap om sosial innovasjon med særlig fokus på studenter.

Vi finner også i vårt materiale flere eksempler på innsatser med et helhetlig lokalsamfunnsperspektiv, et perspektiv på sosialt entreprenørskap og sosial innovasjon som er omtalt i kapittel 3.

Vårt hovedinntrykk er imidlertid at vi finner relativt få eksempler i Norden på innsatser der ambisjonen og målet er å legge til rette for sosialt entreprenørskap og sosial innovasjon generelt. Dette kan både ha sammenheng med at fagfeltet generelt er nytt, og at Norden muligens har tradisjoner for andre former for samarbeid enn det som pr i dag ligger i forståelsen av sosialt entreprenørskap og sosial innovasjon, se kapittel 3.

Samlet ser vi at det er Sverige, Danmark og Norge som aktivt anvender disse betegnelsene om innsatsene de tilbyr.

\subsubsection{Hvordan legger innsatsene til rette?}

\section{Finansiering}

Et område som er særlig fokusert i de erfaringer og den kunnskap vi så langt har knyttet til sosialt entreprenørskap og sosial innovasjon, er hvordan arbeidet skal finansieres. I mange sammenhenger møter denne type entreprenører de samme utfordringer som entreprenører på andre områder. Men fordi målgruppen for det sosialentreprenøriske arbeidet ofte er utsatte grupper i arbeid og samfunnsliv, kan det være et større behov for tilretteleggende innsatser knyttet til finansiering, om man ønsker å fremme entreprenører og innovatører innen det sosiale området.

Det fremgår av det nordiske materialet at finansiering som innsats $\mathrm{i}$ hovedtrekk handler om tilskudd eller lån. Den konkrete innsatsen utløses i hovedsak etter en søknad og er av tidsavgrenset karakter. Dette synes å være nokså likt i Norden. Vi ser imidlertid at det er noe ulikt hvordan især regelverk for tilskudd fra offentlig sektor er innrettet. Vi finner i vårt materiale både eksempler på tilskudd til sosialt entreprenørskap, tilskudd til sosialøkonomiske virksomheter og tilskudd til samfunnsentreprenørskap og sosial innovasjon.

Den tidligere nevnte tilskuddsordningen til sosialt entreprenørskap som forvaltes av Arbeids- og Velferdsdirektoratet i Norge, er et eksempel 
på en ordning som gjennom tildelingskriteriene er spisset mot sosialt entreprenørskap. Tilskudd til samfunnsentreprenørskap og sosial innovasjon som Tillväxtverket forvalter, og midler fra Coompanions lokale kontor til utvikling av foretak i "den sosiale økonomien", er eksempler på tilskudd i landrapporten fra Sverige.

Vi finner at sosiale entreprenører har tilgang både til offentlig finansiering, privat investering og til ulike fonds (både private og stiftelser). Utfordringen kan være at de kan "falle mellom to stoler", da de verken tilhører en ren kommersiell virksomhet eller det rent sosiale, som ofte forbindes med frivillighet.

\section{Rådgivning/kompetanseutvikling}

Det er arbeidsgruppens erfaring og kunnskap at rådgivning og kompetanseutvikling er noe som feltet i stor grad har etterspurt og etterspør. Dette behovet er ikke et ukjent fenomen innen entreprenørskap generelt.

Fordi sosialt entreprenørskap og sosial innovasjon er områder som er nokså nye i nordisk sammenheng, er det grunn til å tro at behovet for nettopp rådgivning og kompetanseutvikling er særlig stort. Vi var derfor opptatt av å finne mer ut av på hvilken måte denne innsatsen legger til rette.

Det fremgår at det samlede nordiske materialet at denne innsatsen $\mathrm{i}$ hovedtrekk består av ulike typer kurs, konferanser, workshops, løpende nettverksdialoger og poenggivende studier. I tillegg finner vi veiledning, rådgivning, samt styremedvirkning. Vi finner ingen store forskjeller i hvordan denne innsatsen legger til rette. I dette ligger at blant de respondenter som beskriver innsatsen å være rådgivning og kompetanseutvikling, finner vi mange av de samme aktivitetene.

\section{Juridisk rammeverk}

I mange tilfeller innen entreprenørskap generelt etterspørres juridisk rammeverk i form av både lovregulering, retningslinjer og ulike former for tilsyn og oppfølging. Dette oppfattes å være viktige strukturelle grep for å fremme et område og angi retning. Imidlertid kan det råde både en faglig og praktisk uenighet om hvilken grad av styring som er ønskelig. Diskusjonen mellom regulering og overstyring er ikke ukjent i noen av de nordiske land. Så også innen området sosialt entreprenørskap og sosial innovasjon.

Arbeidsgruppens erfaring og kunnskap viser at det er et behov for rammeverk, men at dette ikke må bli så rigid at det demper kreativitet og engasjement. Som ledd i kartleggingen ønsket vi derfor å finne mer ut av dette området og hvordan det så langt er rigget.

I det nordiske materialet er juridisk rammeverk en av innsatsene som færrest rapporterer at de har. I alle land finner vi regelverk knyttet til ulike former for arbeid for utsatte grupper i arbeid og samfunnsliv, 
men i liten grad regelverk som er innrettet mot sosialt entreprenørskap og sosial innovasjon. Den danske landrapporten viser til et nytt regelverk knyttet til sosialøkononomiske virksomheter. Den danske regjeringen nedsatte i 2013 Udvalget for socialøkonomiske virksomheder. Arbeidet ble i 2014 fulgt opp på ulike måter, deriblant ved innføring av en lov om registrerte sosialøkonomiske virksomheter.

I Finland finner vi en lov om sosiale foretak og et merke for samfunnsmessige foretak.

Det vises til landrapportene for utdypende redegjørelse.

\section{Inkubatorvirksomhet, nettverksbygging, synliggjøring og lobbing}

Som ledd i utvikling av nye områder anses det ofte som avgjørende at aktører som forsøker seg i ukjent terreng kan møte likesinnede, dele erfaringer og inngå i nettverk. Behovet for inkubatorer som legger til rette for både dette og andre områder kan derfor være stort. Synliggjøring av nye områder anses også som viktig for å få oppmerksomhet som igjen kan bidra til opprettelse av flere former for innsatser, blant annet knyttet til finansiering. Inkubatorvirksomhet, nettverksbygging og synliggjøring står sentralt i entreprenørskap generelt. Arbeidsgruppen var derfor opptatt av disse områdene og på hvilken måte dette kommer til uttrykk i tilrettelegging for sosialt entreprenørskap og sosial innovasjon i Norden.

I de svenske og danske dataene finner vi flere eksempler på synliggjøring og nettverksbygging. I det norske materialet fremgår det også at enkelte miljøer arbeider systematisk for å fremme området, men materialet etterlater et inntrykk av at dette er noe mindre utbredt. Det framgår av landrapporten fra Island at området er nokså prematurt, men her finnes eksempler på inkubatorvirksomhet rettet mot entreprenørskap og innovasjon generelt. Også den finske landrapporten viser at området ikke er viet særskilt oppmerksomhet utover det vi finner innen området samfunnsmessige foretak:

Det forutsettes normalt at samfunnsmessige foretak benytter de samme offentlige tjenestene for foretak som andre foretak benytter. Metoder for rådgivning og kompetanseutvikling av samfunnsmessige foretak i Finland baserer seg også på ulike regionale Europeiska Socialfonden (ESF) finansierte utviklingsprosjekter.

Ser vi nærmere på innholdet i innsatsene, viser landrapportene at inkubatorvirksomhet er å legge til rette for kontorplasser, fysiske møteplasser og møteplasser på sosiale medier samt ulike varianter av seminarer og workshops. Vi finner eksempler på dette især i Sverige, Danmark og Norge.

Nettverksbygging kan være å etablere faste strukturer rundt definerte nettverk, ad-hoc nettverk og fleksible nettverk. Det er også flere som 
viser til bruk av workshops, seminarer og grupper. Det ser ut til å være stor grad av likhet i de nordiske landene når det gjelder hvordan denne innsatsen tilrettelegges. Men igjen er det først og fremst Sverige, Danmark og Norge som har innsatser som tilrettelegger for sosialt entreprenørskap og sosial innovasjon helt spesifikt. Island og Finland viser også til denne form for innsatser, men der sosialt entreprenørskap og sosial innovasjon som begreper ikke er anvendt.

Synliggjøring er en innsats som i liten grad er beskrevet substansielt i landrapportene, med unntak av i det svenske materialet. Her fremgår det blant annet at Malmö Högskola - Mötesplats Social Innovation har en nasjonal, nordisk og internasjonal rolle, der synliggjøring og nettverksbygging står sentralt. I tillegg ser vi at offentlige myndigheter gjennom Tillväxtverket i Sverige, også har en proaktiv rolle i å tilrettelegge for synliggjøring. Vi finner også noen eksempler i Danmark, deriblant miljøet rundt Roskilde Universitet.

Ser vi på lobbing, er også dette et område som det er vanskelig å finne eksempler på hva inneholder helt konkret, med unntak av i det svenske materialet. Lobbing ser ut til å bestå av aktiv innsats for å fremme primært sosialentreprenører og deres arbeid, især overfor offentlige myndigheter og politikk. I det nordiske materialet vises også til at innsatsen lobbing også består av å promotere området overfor ulike private finansieringskilder, herunder fond.

\section{Forskning- og utviklingsarbeid (FoU)}

Innen områder som anses som interessante som bidrag i samfunnsutviklingen vil systematisk forskningsaktivitet ses på som et viktig ledd i utviklingsarbeidet. Det er en rekke eksempler på dette både innen medisinsk, teknologisk og samfunnsvitenskapelig forskning. Sosialt entreprenørskap og sosial innovasjon er viet relativt mye oppmerksomhet innen EU, se kapittel 3. Arbeidsgruppens ønsket derfor også å kartlegge tilretteleggende innsatser på dette området. Arbeidsgruppens kunnskap og erfaringer viste også at FoU aktiviteter innen dette området var blitt mer påaktet i de nordiske landene. Det var vårt inntrykk i forkant av kartleggingen at dette området til dels er svært ulikt innrettet i Norden. Kartleggingen støtter dette inntrykket.

Det samlede nordiske materialet viser at forskning- og utviklingsarbeid (FoU) er relativt ulikt hva gjelder innhold og omfang i de nordiske landene. Fra å være et nokså lite område i Norge, ser vi at især Danmark og Sverige har etablerte miljøer på området, som på mange måter også har vært toneangivende i sine land og inspirert andre land.

Island er, som tidligere vist til, det land som har i minst grad har fokusert på sosialt entreprenørskap og sosial innovasjon som begreper 
innen forskning og utvikling. Det pekes imidlertid på i landrapporten at innovasjon og entreprenørskap generelt står sterkt, og at det er aktive tilretteleggende innsatser for dette både på nasjonalt, regionalt og kommunalt nivå. Dette finner vi for øvrig i alle land. I Finland ser vi at FoU er splittet og skjer hovedsakelig gjennom ulike prosjekter. Sosialt entreprenpørskap som begrep er relativt ukjent i Finland, men det fremholdes at selve innholdet i begrepet inngår i et flertall av prosjekter og programmer som er vist til i landrapporten. Materialet fra Norge etterlater et inntrykk av at FoU rettet mot sosialt entreprenørskap og sosial innovasjon ikke er særlig utbredt, men vi finner noen eksempler, blant disse en privat aktør som har bygd opp et institutt for området og offentlige aktører som har planer for dette.

\section{Utdanning}

I likhet med FoU-virksomhet vil også utdanning være en innsats som kan fremme og drive frem en utvikling. Satsinger på ulike former for utdanning, korresponderer ofte med den utvikling som et storsamfunn eller lokalsamfunn ønsker på kort og lang sikt. Utdanning er derved en kjent innsats for tilrettelegging av definerte områder, og arbeidsgruppen ønsket derfor å se på om, og på hvilken måte, denne innsatsen blir benyttet i Norden.

Materialet viser at Danmark skiller seg ut som det land som ser ut til å ha utviklet mest omfattende strukturer for dette, først og fremst gjennom miljøet på Roskilde Universitet, der vi finner følgende omtale i den danske landrapporten:

Et annet eksempel er Roskilde Universitet, som i sitt Center for Socialt Entreprenørskab både har utdannings-, forsknings- og kunnskapsdelingsaktiviteter med fokus på sosialt entreprenørskap og sosiale innovasjonsprosesser rettet mot sosialt utsatte grupper. Ved senteret tilbyr Roskilde Universitet blant annet en Master i Socialt Entreprenørskab samt en internasjonal kandidatutdanning i Social Entrepreneurship and Management. Når det gjelder forskningsrelaterte aktiviteter har senteret bl.a. tilknyttet ni phd studenter og fem internasjonale gjesteprofessorer. Ut over dette spiller sentret en ledende rolle i både det internasjonale forskernettverket EMES og det nordiske forskernettverket SERNOC. 14

Vi finner også både i Sverige og Norge enkelte eksempler på tilbud om utdanning, se landrapporter for disse landene, men inntrykket er at det-

${ }^{14}$ http://www.ruc.dk/forskning/forskningscentre/cse/ 
te ikke er særlig utbredt. Igjen tar vi forbehold om at det kan være noe vi ikke har fanget opp. I Island finnes det ikke noe eget program for sosialt entreprenørskap eller sosial innovasjon, men det blir undervist i entreprenørskap, innovasjon og tredjesektor organisasjoner ved flere fakultet ved Islands Universitet. I Finland finnes ulike kurs om samfunnsmessige foretak ved enkelte universitet og høgskoler.

\section{Strategier og planer/strategisk utviklingsarbeid og ivaretakelse av foretaks/bedrifters interesser}

For å sikre trykk og fremdrift på en ønsket utvikling, er strategisk innsats nødvendig. Denne type innsats kan forekomme på mange nivåer, fra samfunnsplanlegging på makronivå til virksomhetsplanlegging på mikronivå.

Arbeidsgruppens kjennskap til feltet forut for kartleggingen, viste at sosialentreprenører i felt etterspør tydeligere strategiske grep på samfunnsnivå, men også har behov for innsatser som tilrettelegger for strategisk arbeid og operativt arbeid på virksomhetsnivå (mikronivå).

Flere respondenter har krysset av for strategier og planer/strategisk utviklingsarbeid. I det samlede nordiske materialet er det likevel noe problematisk å finne eksempler på hvordan denne innsatsen legger til rette. Vårt inntrykk er at det er en utvikling på området, og at det arbeides både lokalt, regionalt og nasjonalt.

Et eksempel fra den danske landrapporten er Kolding kommune som har flere støttestrukturer for å fremme vekst av sosialøkonomiske virksomheter. Den finske landrapporten viser til en arbeidsgruppe nedsatt av Arbets- og näringsministeriet 2010 for å vurdere virksomhetsmodellen for samfunnsmessige foretak, herunder om den kan være egnet for å styrke og utvikle entreprenørskap.

Det vises til landrapportene for utdyping og flere eksempler.

\subsubsection{I hvilken grad fokuserer innsatsene på de fire kjennetegnene ved sosialt entreprenørskap}

I kapittel 1 har vi redegjort for arbeidsgruppens forståelse av begrepene sosialt entreprenørskap og sosial innovasjon. I lys av denne forståelsen stilte vi spørsmål om i hvilken grad innsatsene fokuserer på utvikling og utprøving av nye løsninger, involvering av målgruppen for det sosialentreprenøriske arbeidet, samarbeid på tvers av fagfelt og virksomhetsmodeller, og bærekraft (både økonomisk og samfunnsøkonomisk).

I det samlede nordiske materialet ser vi at de aller fleste svarer at innsatsene har fokus på utvikling og utprøving av nye løsninger, målgruppeinvolvering, samarbeid på tvers og bærekraft. Det er ingen store 
forskjeller i svarene fra de ulike landene. I det videre skal se nærmere på det enkelte området.

\section{Utvikle og prøve ut nye løsninger}

Det nordiske materialet viser at det er et lite mindretall som rapporterer at de til "en viss grad" fokuserer på å utvikle og prøve ut nye løsninger. Denne gruppen kjennetegnes av at deres oppdrag ikke er direkte rettet mot å utvikle konkrete tiltak. For eksempel ser vi at respondenter som har utdanning som sitt hovedområde, ikke har utvikling og utprøving av nye løsninger som et fokusområde i seg selv. Derimot vil utvikling med henblikk på ny kunnskap stå sentralt.

\section{Figur 5.4. Utvikle og prøve ut nye løsninger}

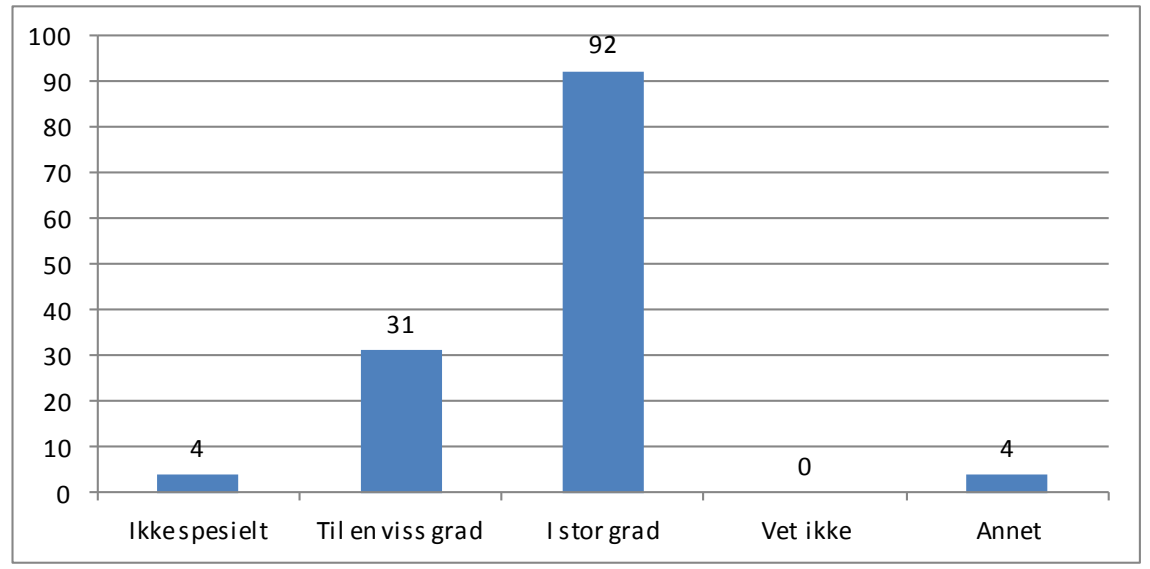

Den klart største gruppen i vårt materiale svarer at de "i stor grad" er opptatt av dette. Så langt vi kan se, har dette sammenheng med at de fleste respondenter arbeider med innsatser som skal bidra til nettopp utvikling og utprøving.

\section{Målgruppeinvolvering}

Den klart største gruppen svarer at de "i stor grad" er opptatt av dette, men det er også en del som sier at de "til en viss grad" eller "ikke spesielt" er opptatt av å involvere målgruppen for det sosialentreprenøriske arbeidet. 
Figur 5.5. Utvikle og prøve ut nye løsninger som involverer målgruppen for det sosialentreprenøriske arbeidet

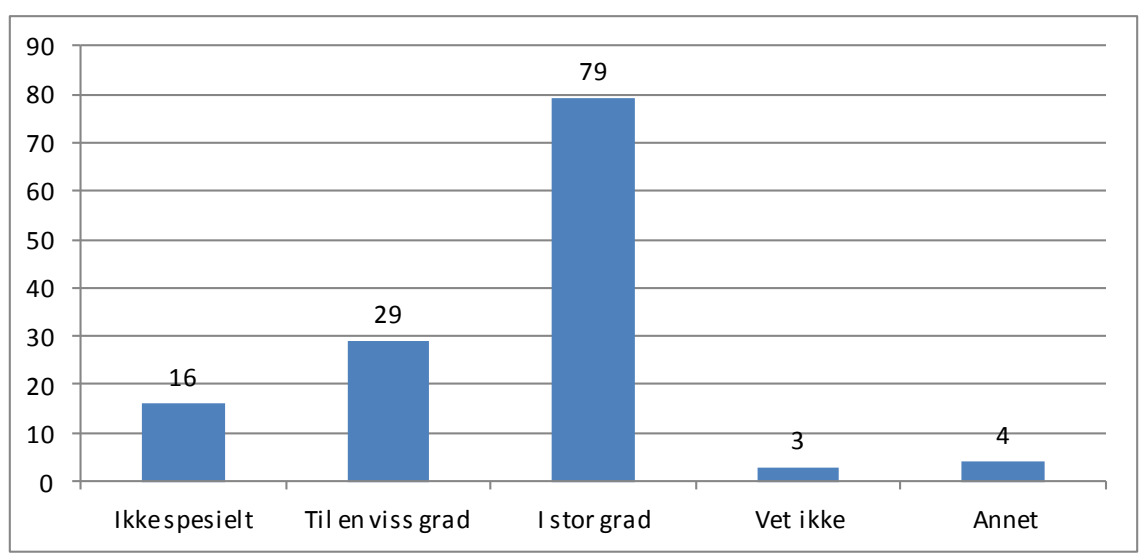

Gjennomgangen av materialet viser at dette har sammenheng med hva som er respondentenes oppdrag og posisjon. For eksempel ser vi av vårt materiale at noen av respondentene selv er aktive utøvere i felt, det vil si at de arbeider i direkte kontakt med utsatte grupper. Målgruppeinnvolvering vil derved knytte seg til om "de utsatte" blir trukket aktivt inn i utformingen av tiltak mv. Andre respondenter er kun tilretteleggere, det vil si at deres innsatser skal bidra til å stimulere til arbeid i felt. Målgruppen er derved for eksempel virksomheter, og ikke "sluttbrukeren". Denne ulike forståelsen av begrepet målgruppe, kan ha preget svarene.

Stimulere til samarbeid på tvers av fagfelt og virksomhetsmodeller Den klart største andelen av våre respondenter rapporterer at de "i stor grad" er opptatt av å stimulere til samarbeid på tvers av fagfelt og virksomhetsmodeller.

Figur 5.6. Stimulere til samarbeid på tvers av virksomhetsmodeller

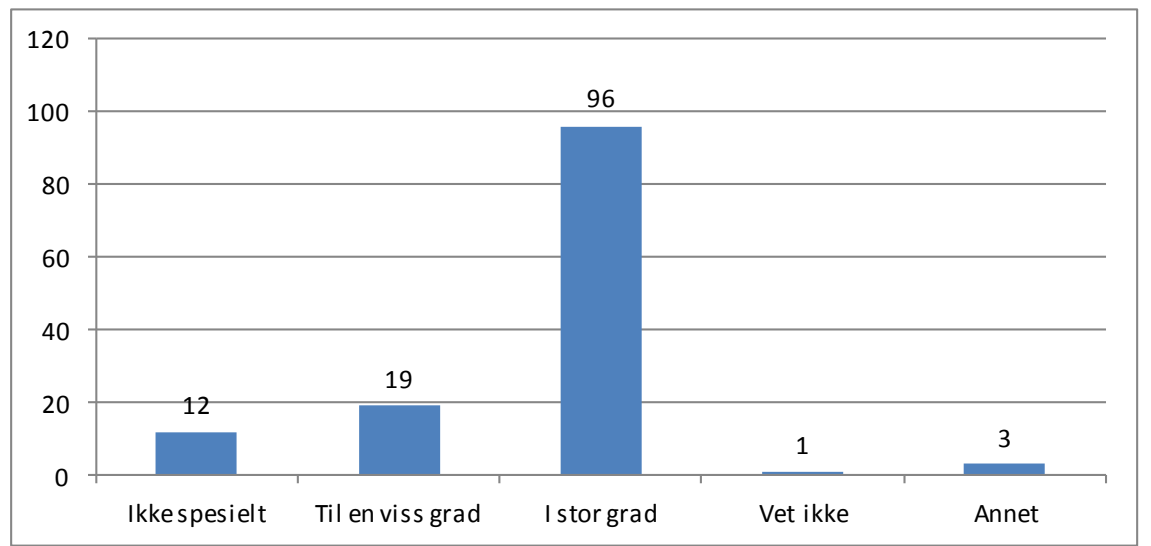


Et kjennetegn ved sosialentreprenørisk arbeid er nettopp samarbeid på tvers, se kapittel 3. Vi kunne derfor forvente å finne en høy andel som svarer dette. Vi finner det likevel, noe overraskende, at andelen er såvidt høy. Dette kan muligens ha sammenheng med at samhandling og samarbeid på tvers også gis mye oppmerksomhet innen det sosiale området generelt.

Den gruppen som ikke er særlig opptatt av et slikt fokus representerer $i$ hovedsak en gruppe som har et mer avgrenset oppdrag eller mandat, for eksempel fondstildelere, tilskuddsforvaltere og i noen grad utdanning.

Vi finner ingen særlige forskjeller mellom de nordiske land på dette området.

\section{Utvikle bærekraft, både økonomisk og samfunnsøkonomisk}

De fleste respondentene beskriver seg også "i stor grad" å ha fokus på å utvikle bærekraft, både økonomisk og samfunnsøkonomisk.

Figur 5.7. Utvikle bærekraft, både økonomisk og samfunnsøkonomisk

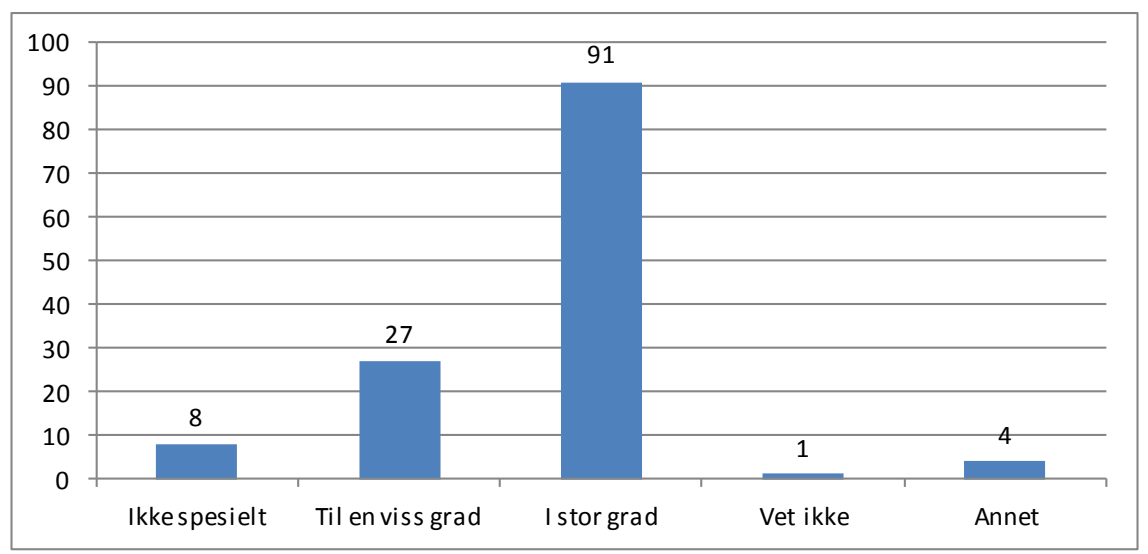

Det er ingen klare forskjeller i det nordiske materialet. Vi finner at innsatser som skal bidra til bærekraft i stor grad dreier seg om rådgivning og nettverksbygging. I noen grad er det direkte finansielle bidrag. De respondentene som rapporterer at de "til en viss grad" eller "ikke spesielt" har fokus på bærekraft, er i hovedsak respondenter der denne form for fokus ikke er fremtredende i oppdraget de forvalter.

\subsubsection{Hvilke hindre og behov for nye innsatser for sosialt entreprenørskap ser respondentene?}

Arbeidsgruppen er i mandatet bedt om å komme med anbefalinger om videre oppfølging. Som en del av grunnlaget for å gi slike anbefalinger vurderte vi det som interessant å be om respondentenes vurderinger av 
de viktigste hindre for utvikling av sosialt entreprenørskap og sosial innovasjon i arbeidet for å inkludere utsatte grupper i arbeid og samfunnsliv, og behovet for nye innsatser. De samme spørsmålene burde også ha vært stilt brukerne/mottakerne av innsatsene, men det har ikke vært mulig å gjennomføre innenfor rammen for denne kartleggingen.

Svarene fra respondentene kan og må forstås ut fra den nasjonale konteksten og området som respondentene arbeider på. Vi ser blant annet at på samme måte som i svarene på de andre spørsmålene, varierer det om det er begreper som sosialt entreprenørskap, sosialøkonomiske virksomheter, sosiale foretak mv. som benyttes.

Det er samtidig et generelt inntrykk at mange av de samme hindre og behov for nye innsatser er å finne i svarene fra respondenter i alle land. Vi vil oppsummere disse i følgende hovedkategorier:

- Finansiering og andre støttestrukturer.

- Regelverk og praktisering av regelverk.

- Kunnskap om sosialt entreprenørskap og sosial innovasjon.

- Holdninger, kultur og organisering i det offentlige.

\section{Finansiering og andre støttestrukturer}

Manglende tilgang til finansiering og utilstrekkelige eller manglende støttestrukturer, er hindre som nevnes av respondenter i alle land.

Noen peker på manglende tilgang til finansiering og støtte ved oppstart av ny virksomhet, andre på manglende tilgang til finansiering og støtte for å opprettholde en virksomhet over tid. Sosiale entreprenører kan oppleve utfordringer knyttet til likviditet. Tiden etter at offentlige midler tar slutt kan også være krevende.

For små økonomiske rammer for offentlige midler og for mye fokus på prosjektmidler er andre hindre som nevnes. Det pekes likeledes på at eksisterende finansieringsmuligheter ikke er godt nok tilpasset de behov og forutsetninger som sosiale entreprenører har.

Andre er opptatt av manglende tilgang til risikovillig finansiering og peker på behov for mer private midler i arbeidet for å inkludere utsatte grupper.

Manglende tilgang til finansiering gjelder ikke bare for sosiale entreprenører, men også for støttestrukturer som rådgivning, inkubatovirksomhet med mer.

Som svar på disse utfordringene pekes på behov for bedre finansieringsmuligheter både fra det offentlige og andre finansieringskilder (risikokapital). Noen forslag er ganske generelle, andre mer konkrete. Det 
handler om gode finansieringsløsninger ved oppstart, såkornfinansiering, forskuddsbetaling av prosjektmidler, sikkerhet/garantier, etablererstipend og låneordninger, og reserverte kontrakter. Andre ønsker er etablering av et nasjonalt fond på tvers av sektorer, mer målrettede midler i fond, målrettede anskaffelser, og tilpasning av kriterier ved fordeling av midler fra EU-fond.

Flere peker på behov for mer langsiktig støtte, gi utviklingsmidler for en lengre periode slik at virksomheter kan vokse og utvikle seg over tid. Det er behov for låne- og støttemuligheter for å utvikle og fastholde kompetanse hos aktører som engasjerer seg i sosialt entreprenørielle prosjekter for å unngå at initiativ "dør" ved utgangen av en støtteperiode. Andre ønsker større tilgang til venture kapital rettet mot å skape sosiale forandringer, skattemessige insentiver og nye verktøy for å løse utfordringer for de som ikke har sikkerhet for lån.

\section{Regelverk og praktisering av regelverk}

Regelverk og praktisering av regelverk er også hindre som nevnes av respondenter i alle land.

Det er særlig utfordringer knyttet til regelverk for offentlig anskaffelser og praktiseringen av dette som nevnes. Kvalitet, samfunnsansvar og sosial verdi bør i større grad etterspørres framfor pris.

Noen peker på behov for bedre tilpasning av regelverk/ordninger under arbeidsmarkedspolitikken og sosialpolitikken, og et forslag er at det bør være mulig for offentlige myndigheter å inngå rammeavtaler med sosiale entreprenører på lik linje med andre aktører.

\section{Kunnskap om sosialt entreprenørskap og sosial innovasjon}

Manglende kunnskap om sosialt entreprenørskap og sosial innovasjon er også blant hindre som nevnes av respondenter $\mathrm{i}$ alle land.

Noen peker på manglende kunnskap i samfunnet generelt, andre på manglende kunnskap blant offentlige myndigheter spesielt. Manglende kunnskap om å jobbe tverrprofesjonelt og tverrsektorielt, og manglende kunnskap om metoder for å involvere brukere av tjenestene, er hindre trekkes fram av flere.

Som svar på disse utfordringene nevnes en stor bredde av forskjellige innsatser.

Noen peker på behovet for et større fokus på utdanning og forskning på sosialt entreprenørskap, og et forslag er å opprette nasjonalt kompetansesenter.

Blant mer konkrete forslag er å kartlegge og spre gode eksempler (beste praksis), utvikle gode metoder for resultat- og effektmåling og gevinster ved å jobbe forebyggende, og å gjennomføre en informasjonskampanje. 
Det pekes på behovet for å spre kunnskap om sosialt entreprenørskap og sosialøkonomiske virksomheter med særlig fokus på den sosiale verdien disse tilfører samfunnet.

Det pekes også på behovet for utdanning for de sosiale foretakene/entreprenørene, mer samarbeid mellom forskere og sosiale entreprenører, inkubatorprogram, og mentorskap.

\section{Holdninger, kultur og organisering i det offentlige}

Holdninger, kultur og organisering i det offentlige nevnes også som hindre av respondenter $i$ alle land.

Noen peker på at det et motsetningsforhold mellom sosialt entreprenørskaps tverrsektorielle og tverrfaglige karakter og offentlige aktørers typiske organisering i spesialiserte forvaltningsenheter eller "siloer". Andre mener at det er manglende kompetanse og insentiver i det offentlige til å samarbeide på tvers av forvaltninger og sektorer. Noen peker på at organisering gjør det uklart hvem/hvilken sektor som har ansvar for hva, ingen ser saken som sin egen. Holdninger i det offentlige nevnes som et problem.

Som svar på disse utfordringene, pekes på behov for å se på hvordan strukturer og systemer kan mykes opp, så de ikke bremser for sosialt entreprenørskap. Økt kunnskap blant offentlige ansatte om metoder for og effekter av sosialt entreprenørskap og sosial innovasjon kan medvirke til økt samarbeid.

Det pekes på behov for tettere samarbeid mellom offentlige myndigheter og henholdsvis privat og frivillig sektor om løsning av velferdsutfordringer, og at et slikt tverrsektorielt samarbeid vil kreve større tillit, likeverdighet og risikovillighet fra offentlige ansattes side.

\subsubsection{Oppsummerende kommentar}

Vi finner i det samlede nordiske materialet en rekke innsatser for å tilrettelegge for sosialt entreprenørskap og sosial innovasjon. Det er særlig Sverige, Danmark og Norge som anvender disse begrepene og ved dette også har innsatser for å legge til rette både for området generelt og inkludering av utsatte grupper i arbeids og samfunnsliv spesielt.

Både i Island og i Finland har det over mange år eksistert ordninger som skal stimulere til etablering av virksomheter som arbeider med sosialt utsatte grupper, men dette defineres ikke som sosialt entreprenørskap eller sosial innovasjon. Ulike innsatser som skal legge til rette for arbeid med sosialt utsatte, men der dette ikke defineres som sosialt entreprenørskap eller sosial innovasjon, finner vi for øvrig i alle nordiske land. Tiltak for inkludering av utsatte grupper i arbeid og samfunnsliv 
er et viktig kjennetegn ved den nordiske velferdsmodellen slik vi pekte på innledningsvis.

Vårt hovedinntrykk er at innsatser for å legge til rette for sosialt entreprenørskap og sosial innovasjon, er et relativt nytt område som det i de siste fem til syv årene har blitt mer oppmerksomhet om.

Det er et generelt inntrykk at respondentene i alle land opplever mange av de samme hindre og behov for nye innsatser for å legge til rette for sosialt entreprenørskap og sosial innovasjon. I svarene på spørsmål om dette, peker respondentene på hindre og behov for nye innsatser innenfor følgende områder: Finansiering og andre støttestrukturer, regelverk og praktisering av regelverk, kunnskap om sosialt entreprenørskap og sosial innovasjon, samt holdninger, kultur og organisering i det offentlige. 



\section{饿}

\section{Innsatser for sosialt entreprenørskap og sosial innovasjon i Danmark}

\subsection{Innledning}

I Danmark har framveksten av sosial entreprenørskap og sosial innovasjon i stor utstrekning vært drevet av enkeltpersoner, sosialøkonomiske virksomheter, (socialøkonomiske virksomheder), organisasjoner fra sivilsamfunnet og fond. Området har imidlertid de siste årene fătt økt oppmerksomhet av offentlige myndigheter og politisk nivå, særlig gjelder dette den delen av sosialt entreprenørskap som handler om etablering av sosialøkonomiske virksomheter. Når det gjelder utdanning og forskning på området har Danmark, blant annet med etableringen av Center for Socialt Entreprenørskab ved Roskilde Universitet, vært forholdsvis lang framme og tidlig ute i forhold til de andre nordiske landene.

Sosialøkonomiske virksomheter har i de siste årene fått økt oppmerksomhet fra offentlige aktører både på lokalt og nasjonalt nivå. Den første danske kommune utarbeidet en strategi for å fremme sosialøkonomiske virksomheter allerede i 2009. Det er vårt inntrykk at et stadig $\varnothing$ kende antall kommuner arbeider med å fremme sosialøkonomiske virksomheter lokalt.

På nasjonalt nivå har det fra 2012 til og med 2015 vært avsatt midler fra Beskæftigelsesministeriet til å støtte etablering og opprettholdelse av sosialøkonomiske virksomheter som arbeider med utsatte arbeidsledige. Gjennom finanslovsavtalen for 2013 ble det i tillegg avsatt 25 mill DKR for å fremme sosialøkonomiske virksomheter, bl.a. ved å sette ned et utvalg som skulle avdekke barrierer og muligheter på området, samt å komme med anbefalinger.

Med utgangspunkt i utvalgets anbefalinger har Beskæftigelsesministeriet og Ministeriet for Børn, Ligestilling, Integration og Sociale forhold $\mathrm{i}$ 2014 styrket den nasjonale innsatsen for sosialøkonomiske virksomhe- 
ter.15 Det har blant annet blitt vedtatt en lov om registrerte sosialøkonomiske virksomheter, etablert et nasjonalt vekstsenter og et Råd for Socialøkonomiske Virksomheder.

Fokus på, og bruk av, begrepene sosialt entreprenørskap og sosial innovasjon virker å være spesielt fremtredende blant aktører i sivilsamfunnet.

\subsection{Respondentene}

I den danske delen av kartleggingen ble det sendt ut spørreskjemaer til 27 aktører med innsatser rettet mot å fremme sosialt entreprenørskap og sosial innovasjon.

23 av de 27 respondentene svarte på det utsendte spørreskjemaet.

De kartlagte innsatsene har i hovedsak oppgitt at de befinner seg enten innenfor offentlig sektor (10 innsatser) eller tredje sektor (10 innsatser). Blant de offentlige innsatsene er det fem kommuner. To av de kartlagte innsatsene har oppgitt at de befinner seg i privat sektor.

Innsatsenes fordeling på sektor fremgår av figuren under:

Figur 6.1. Sektor

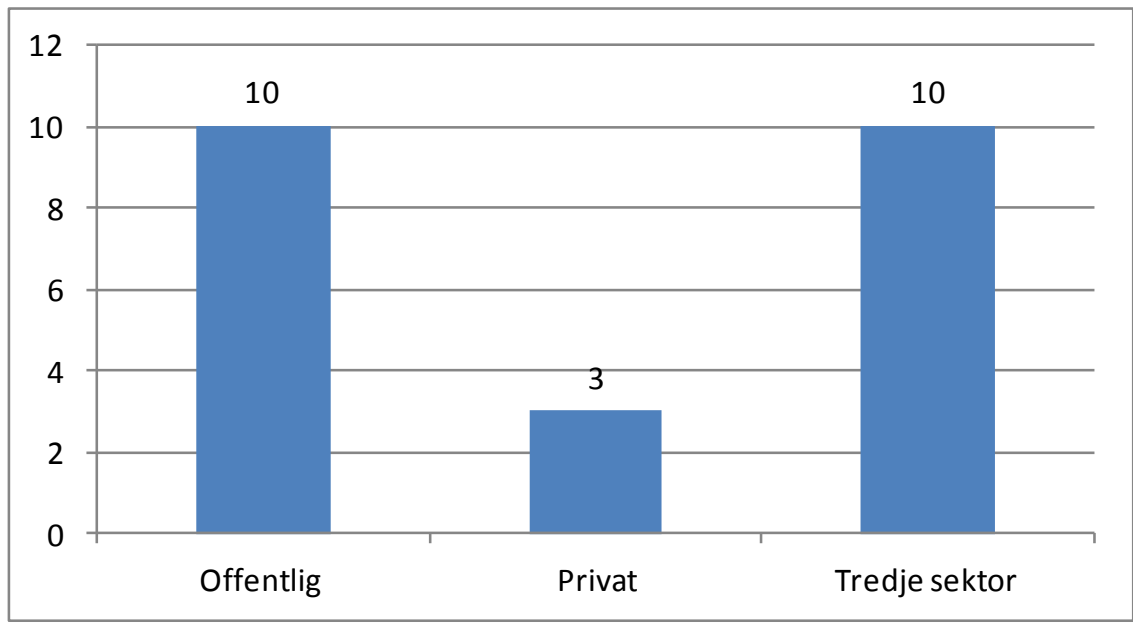

15 www.socialvirksomhed.dk 


\subsection{Hvilke hovedtyper innsatser er kartlagt}

For å kunne kategorisere innsatsene ble respondentene spurt hvilken eller hvilke kategorier som best dekker den innsats eller de innsatsene deres organisasjon arbeider med. Av svarene fremgår det at de fleste innsatsene faller innenfor mer enn en enkelt kategori. På samme måte fremgår det at de kartlagte danske innsatsene fordeler deg forholdsvis bredt på de forskjellige kategoriene.

Innsatser rettet mot rådgivning og kompetanseutvikling, nettverksbygging, synliggjøring og strategier og planer er likevel særlig utbredt, mens bare noen få av de aktørene som har svart, har aktiviteter innenfor henholdsvis finansiering, FoU og juridisk rammeverk.

Innsatsenes fordeling på fokusområder fremgår av figuren nedenfor:

Figur 6.2. Innsatstyper

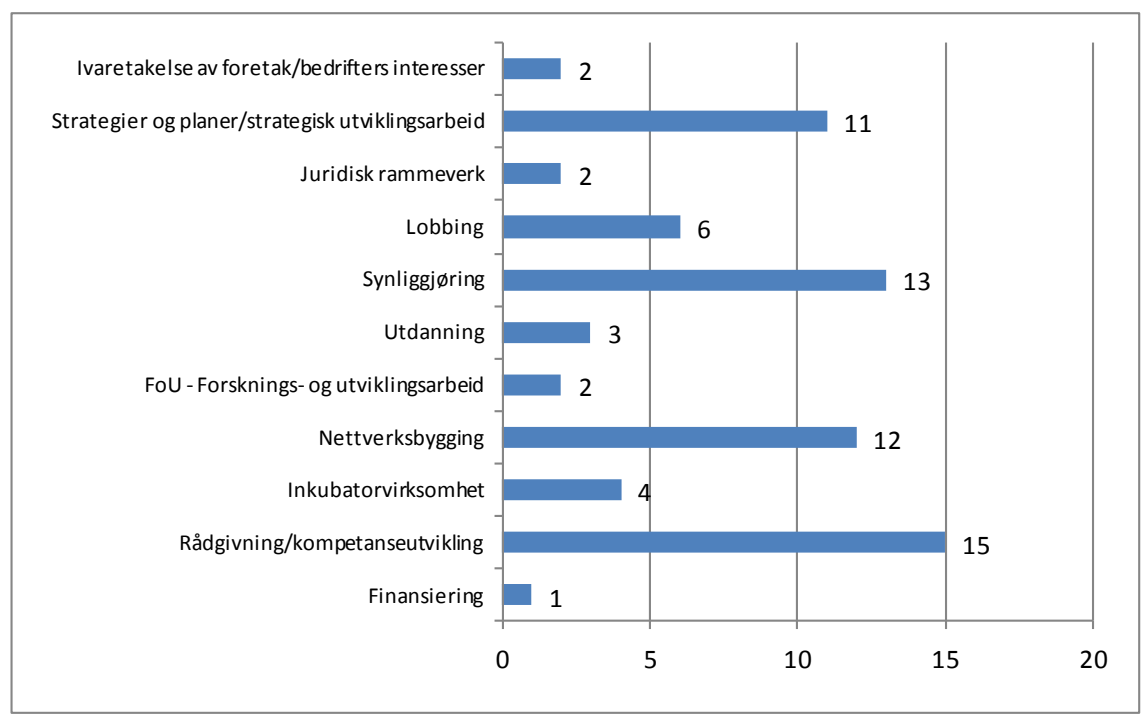

\subsection{I hvilken grad er dette nye innsatser}

Det er et generelt kjennetegn at de fleste av de kartlagte danske innsatsene er relativt nye. 16 av initiativene er igangsatt i 2012 eller senere, fire er igangsatt i perioden mellom 2010 og 2012, mens bare tre initiativer er igangsatt før 2010. 


\subsection{Hva er formål og målgruppe for innsatsene}

Blant de danske innsatsene finnes det både innsatser som retter seg spesifikt mot å fremme sosialt entreprenørskap og sosial innovasjon i arbeidet for å inkludere utsatte grupper i arbeid og samfunnsliv, og innsatser som retter seg mot å fremme sosialt entreprenørskap og sosial innovasjon mer generelt.

I den første gruppen finnes blant annet Det Sociale Vækstprogram, som gjennomføres av Den Sociale Kapitalfond og finansieres av Beskæftigelsesministeriet. Innsatsens formål er her å støtte utviklingen av sosialøkonomiske virksomheter som er sosialt inkluderende og konkurransedyktige på samme tid. Et annet eksempel er Ikast-Brande kommune, som i sitt arbeid med sosialøkonomiske virksomheter har en konkret målsetting om å skape 100 sosialøkonomiske arbeidsplasser innen utgangen av 2017. Et tredje eksempel er Social+, som arbeider for å fremme sosiale oppfinnelser som løser eller forebygger sosiale problemer for utsatte mennesker.

I den andre gruppen av respondenter finner vi eksempelvis studentorganisasjonen DANSIC, som arbeider bredt for å fremme sosial innovasjon og idéutvikling, blant annet gjennom en stor årlig konferanse som retter fokus mot området. Et annet eksempel er Københavns kommuner, som på grunnlag av en strategi fra 2010 har arbeidet bredt med å fremme sosialøkonomiske virksomheter og oppstartsvirksomhet i kommunen.

\subsection{Hvordan er innsatsene finansiert}

Åtte av de kartlagte innsatsene oppgir at de er finansierte av offentlige midler, to innsatser av private fond, to innsatser ved brukerbetaling og en innsats av private investorer. Hele ti innsatser har imidlertid valgt svarmuligheten "annet" på dette spørsmålet. Av disse oppgir de fleste at det skyldes at innsatsene baserer seg på flere forskjellige finansieringskilder. ${ }^{16}$

\footnotetext{
${ }^{16}$ Det har vært en feil i spørreskjemaet når det gjelder dette spørsmålet. Dette har ført til at det ikke har vært mulig å velge flere finansieringskilder. En kan derfor anta at respondenter som har oppgitt kun en finansieringskilde, kan ha flere, men at de har valgt å oppgi den primære kilden.
} 
Figur 6.3. Finansieringskilder

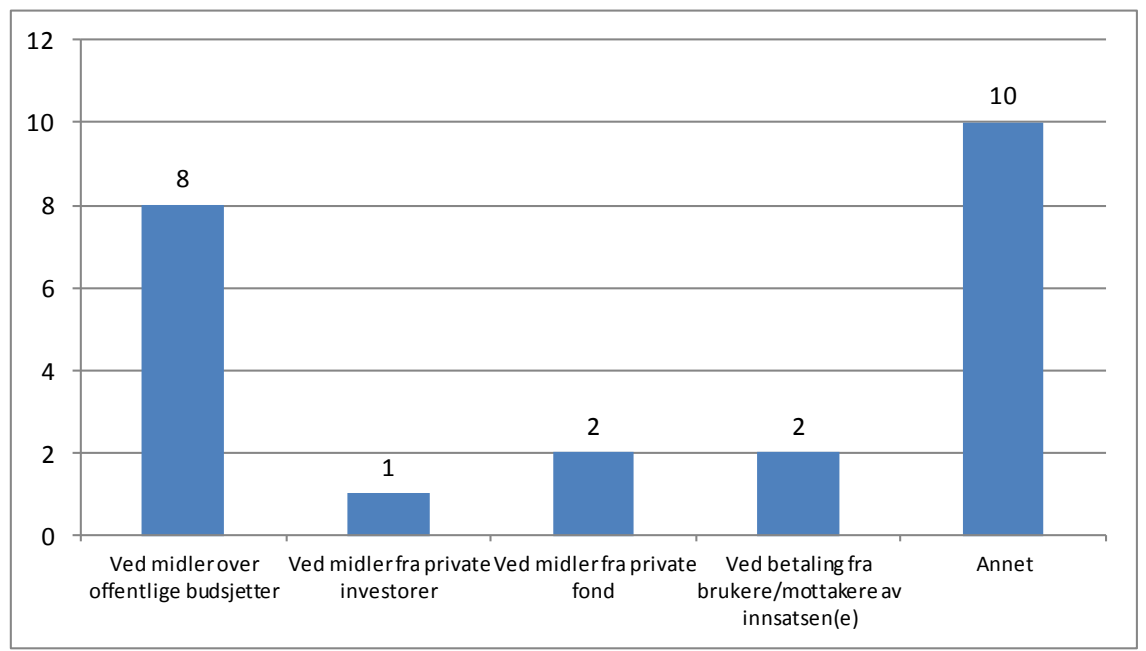

\subsection{Hvordan legger innsatsene til rette}

I det følgende gis det eksempler på hvordan de danske innsatsene, fordelt på de ulike innsatstypene, arbeider for å fremme sosialt entreprenørskap og sosial innovasjon.

\section{Finansiering}

Kun en av de danske innsatsene, Den Sociale Kapitalfond, oppgir at de arbeider med finansiering. Fondet tilbyr finansiering til virksomheter som har vekstpotensial og målrettet skaper muligheter og arbeid for utsatte grupper i Danmark, herunder sosialøkonomiske virksomheter. Fondet investerer i virksomhetene enten i form av "tålmodige lån" eller egenkapital.

Investeringene er tidsbegrenset gjennom avtaler med de enkelte virksomhetene, og har som formål å hjelpe virksomhetene til å vokse, samt styrke deres evne til å være inkluderende overfor utsatte grupper og konkurransedyktige på samme tid. Når investeringene betales tilbake, reinvesteres de i nye virksomheter.

Det Sociale Kapitalfond ble etablert med finansiering fra TrygFonden i 2011.

\section{Rådgiving og kompetanseutvikling}

Blant innsatser med fokus på kompetanseutvikling finner vi aktiviteter som kurs og annen utdannelse, sparring, rådgivning, mentorordninger, informasjonsaktiviteter og annen kunnskapsformidling. De spesifikke aktivitetene varierer på tvers av innsatsenes spesifikke fokus og målgruppe. 
Flere av innsatsene arbeider med å utvikle kunnskap om, og tilby redskaper for, sosial innovasjon. Et eksempel er her Socialt, som arbeider med å fremme og styrke sosial innovasjon hos organisasjoner, fond og myndigheter. ${ }^{17}$ Social+ er delt inn i tre programmer, hvor man henholdsvis hjelper med å utvikle en organisasjons eksisterende idé eller initiativ, hjelper med å spre en organisasjons idé, eller hjelper med å utvikle en organisasjons neste initiativ fra bunnen av.

Andre innsatser, herunder flere av kommunene som har respondert, har fokus på å styrke kompetanseutvikling i sosialøkonomiske virksomheter. Dette gjøres bl.a. ved å tilby sparring og rådgivning i forretningsutvikling, eller ved å støtte opp omkring sosial oppstartsvirksomhet.

Et eksempel på en tredje type innsats er Danmarks Almene Boliger $(B L)$, som er en interesse- og bransjeorganisasjon for cirka 550 allmenne boligorganisasjoner i Danmark. ${ }^{18} B L \emptyset$ nsker å styrke etableringen av sosialøkonomiske virksomheter i foreningens boligområder, som kan hjelpe utsatte grupper til å komme nærmere arbeidsmarkedet.

Den nylig påbegynte innsatsen har som formål å gi et overblikk over erfaringer med og interessen for sosialøkonomiske virksomheter blant $B L s$ medlemmer, samt gi råd om hva boligorganisasjoner kan og må i forhold til sosialøkonomiske virksomheter. I tillegg arbeides det med å forbedre kunnskapen om fordeler med å beskjeftige seg med sosialøkonomiske virksomheter i allmenne boligområder, eksempelvis på politisk nivå. Arbeidet skal munne ut i en guide for sosialøkonomi i boligområder.

\section{Inkubatorvirksomhet}

Blant innsatser med fokus på inkubatorvirksomhet finner vi bl.a. de to programmene Det Sociale Vækstprogram og Social Startup. I de to programmene tilbys henholdsvis sosialøkonomiske virksomheter og sosialøkonomiske iverksettere et intensivt kompetanseutviklingsforløp med fokus på forretningsutvikling. Forløpene har en varighet på cirka fem måneder.

I Det Sociale Vækstprogram får deltakende sosialøkonomiske virksomheter eksempelvis tilknyttet en profesjonell forretningsutvikler som følger virksomheten gjennom hele forløpet. Ut over det arrangeres det en rekke "camps" og kurs for deltakende virksomheter. Virksomhetene får adgang til rådgivning fra profesjonelle revisorer og advokater, adgang til nettverksmuligheter og mulighet til å søke utviklingsmidler.

\footnotetext{
17 http://socialeopfindelser.dk/

18 http://www.bl.dk/boligsociale-tiltag/socialoekonomiske-virksomheder-i-almene-boligomraader/
} 


\section{Nettverksbygging}

Blant innsatser med fokus på nettverksbygging finner vi aktiviteter som nettverksforeninger, nettverk bygd rundt kontorfellesskap, kunnskapsdeling, prosjektorientert samarbeid mellom organisasjoner, samt felles erfaringsutveksling og idéutvikling.

Socialøkonomi Nordjylland er her et eksempel på en nettverksforening for sosialøkonomiske virksomheter og igangsettere. ${ }^{19}$ Foreningen arbeider for å samle krefter fra regionen med interesse for sosialøkonomi til felles erfaringsutveksling, sparring og utvikling av nye ideer. Samtidig yter de også gratis bistand til sosialøkonomiske igangsettere. Det overordnede formålet er å utbre sosial økonomi og sosialt entreprenørskap i Nordjylland, og forsøke å stimulere til samarbeid på tvers av fagområder, sektorer og organisasjonsformer.

Et annet eksempel på nettverksbygging rundt sosialt entreprenørskap er Center for Socialt Ansvar (CFSA). ${ }^{20}$ CSFA er et privat nettverk for en rekke frivillige organisasjoner som arbeider tverrsektorielt med blant annet regioner, kommuner, næringsliv, fond, forskere og frivillige organisasjoner om implementering av en rekke konkrete sosiale prosjekter. Konkret består CFSA av et sekretariat, som leder og drifter sentrets aktiviteter, samtidig som de også gir råd til og veileder andre som vil starte nye initiativer og prosjekter med samme verdier og mål.

\section{Forskning, utvikling og utdanning (FoU)}

Blant innsatser med fokus på forskning, utvikling og utdanning finner vi blant annet utvikling og tilbud om utdanninger med fokus på sosialt entreprenørskap, forskning og læringsforløp for utsatte unge.

Et eksempel på utvikling av nye utdanningstilbud på området er profesjonshøgskolen VIA University College, som har en samlet satsing der de arbeider med å gi sine studenter mulighet til å tilegne seg kunnskap om sosialt entreprenørskap og sosial innovasjon. ${ }^{21}$ Innsatsen består av et vitensenterprogram $i$ sosialt entreprenørskap og sosial innovasjon, utvikling av moduler i profesjonsutdanninger på bachelornivå, utvikling av et forslag om en egen profesjonsutdanning i sosialt entreprenørskap på bachelornivå, samt opprettelse av studentveksthus og kompetanseutvikling av undervisere.

\footnotetext{
19 http://www.socialoekonominordjylland.dk/ind ex.php/om-socialokonomi-nordjylland

${ }^{20}$ www.cfsa.eu

${ }^{21} \mathrm{http} / /$ www.viauc.dk/hoejskoler/psh/videncentre/socialpaedagogik-og-socialt-arbejde/socialt-

entreprenoerskab/Sider/socialt-entreprenorskab.aspx
} 
Et annet eksempel er Roskilde Universitet, som i sitt Center for Socialt Entreprenørskab både har utdannings-, forsknings- og kunnskapsdelingsaktiviteter med fokus på sosialt entreprenørskap og sosiale innovasjonsprosesser rettet mot sosialt utsatte grupper. ${ }^{22}$ Ved senteret tilbyr Roskilde Universitet blant annet en Master i Socialt Entreprenørskab samt en internasjonal kandidatutdanning i Social Entrepreneurship and Management. Når det gjelder forskningsrelaterte aktiviteter har senteret bl.a. tilknyttet ni phd studenter og fem internasjonale gjesteprofessorer. Ut over dette spiller sentret en ledende rolle i både det internasjonale forskernettverket EMES og det nordiske forskernettverket SERNOC.

Et tredje eksempel på utdanningsrelaterte aktiviteter på området er $\mathrm{KBH}+$, som blant annet tilbyr læringsforløp, brobygging til utdanning og arbeid, og sosialfaglig rådgivning til unge. ${ }^{23}$ Forløpene skal styrke utsatte unges muligheter til å innfri sitt potensial gjennom å tilby en annerledes tilgang til utdanning, læring og kompetanseutvikling. Visjonen er å understøtte unges utvikling og samfunnsdannelse, og å være en sterk drivkraft i utviklingen av modeller for sosial inkludering av unge. Arbeidet foregår på tvers av sektorer for at skape et fleksibelt system for den enkelte unge.

\section{Synliggjøring, lobbing og/eller ivaretakelse av foretaks/bedrifters interesser}

Blant innsatser med fokus på synlighet, lobbing og/eller ivaretakelse av foretaks/bedrifters interesser finner vi aktiviteter som konferanser og større arrangementer, konkurranser, organisering og lobbing, samt nyhetsbrev og annen kunnskapsdeling gjennom blant annet sosiale medier.

Et eksempel her er de to studentorganisasjonene FOSIA og DANSIC, som begge arbeider med å spre kunnskap om sosial innovasjon med særlig fokus på studenter. DANSICs primære aktivitet er en årlig heldagskonferanse, hvor 300 studenter og cirka 100 ledere fra privat, offentlig og frivillig sektor møtes, diskuterer og inspirerer hverandre til sosial innovasjon, inngåelse av nye partnerskap og oppstart av sosiale virksomheter. På konferansen avholdes også en idékonkurranse pitch@DANSIC - hvor sosiale innovatører legger fram sine ideer for deltakerne og et dommerpanel. Vinnerne blir premiert med kontorplass, et rådgivningsforløp og startkapital. ${ }^{24}$

\footnotetext{
22 http://www.ruc.dk/forskning/forskningscentre/cse/

$23 \mathrm{http}: / /$ www.kbhplus.dk/

24 http://www.dansic.org/
} 
Et annet eksempel på innsatser med fokus på synlighet er foreningen Sociale Entreprenører i Danmark, en forening for alle med interesse i og ønske om å fremme feltet for sosialt entreprenørskap. ${ }^{25}$ Foreningen holder blant annet nettverksmøter, dialog- og utviklingsarrangementer og studieturer med formål å informere om sosialt entreprenørskap, skape rom for nettverk, samt å bidra til utviklende dialog, kunnskapsdeling og kompetanseutvikling for sosiale entreprenører. Foreningen gir dessuten ut et nyhetsbrev om området og driver en informasjonsside på Facebook.

\section{Strategi og planer/strategisk utviklingsarbeid}

Blant innsatser med fokus på strategi og planer finner vi blant annet de fem kommunene som har svart, og som i forskjellig omfang har arbeidet strategisk for å fremme sosialøkonomiske virksomheter. Blant virkemidlene i kommunenes innsatser finner vi blant annet oppsøkende kontakt med virksomheter og iverksettere, støttemuligheter, nettverksbygging, mulighet for permisjon med lønn for kommunale medarbeidere, styrket samarbeid på tvers i forvaltningen, og tett tverrsektorielt samarbeid, blant annet ved å samle foreninger, prosjekter og institusjoner mv. på ett fysisk sted.

Et eksempel på en kommunal innsats er Kolding, som i 2009 var den første kommunen i Danmark som laget en sammenhengende strategi for vekst i den sosiale økonomien. ${ }^{26}$ Kolding kommune har i dag støttestrukturen for fremme av sosialøkonomiske virksomheter på plass. Blant annet er det etablert et lokalt kunnskapssenter - Socialøkonomisk Center Trekanten - og et fond med risikovillig kapital til oppstart av sosialøkonomisk virksomhet. Innsatsen fokuserer overordnet på å skape sammenheng mellom fagforvaltninger og på å opprette tverrkommunale utvalg og samarbeidsfora. Blant annet samarbeides det tett med kommunens egen næringsorganisasjon - Business Kolding. Kolding kommune er på gang med en versjon 2 av sin strategi for sosial økonomi.

Ikast-Brande kommunes prosjekt Vision Vestergade er et nyere eksempel på en kommunal strategi rettet mot å styrke den sosialøkonomiske innsats. ${ }^{27}$ Navet for innsatsen er et fysisk senter på Vestergade i Ikast som skal romme sosialøkonomiske virksomheter og iverksettere, samt en rekke foreninger. Samtidig skal senteret fungere som sentrum for rådgivning og veiledning for sosialøkonomiske virksomheter og

\footnotetext{
25 http://www.xn--sociale-entreprenrer-rcc.dk/

${ }^{26} \mathrm{http}: / /$ soct.dk/

27 http://www.ikast-brande.dk/om-kommunen/mental-frikommune/projekter-og-tiltag/vision-vestergade
} 
iverksettere. Det overordnede målet for innsatsen har vært å etablere fem sosialøkonomiske virksomheter og 100 sosialøkonomiske arbeidsplasser - bredt definert som "fleksjob, skånejob og beskyttet beskæftigelse" - innen utgangen av 2017. Da innsatsen har kommet riktig godt i gang fra oppstart, har kommunen oppjustert disse målene til hhv. 10 virksomheter og 200 arbeidsplasser innen 2020.

\section{Juridisk rammeverk}

Blant innsatser med fokus på juridisk rammeverk finner vi den danske regjeringens innsats for å fremme sosialøkonomiske virksomheter.

Den danske regjeringen satte i 2013 ned Udvalget for socialøkonomiske virksomheder, som hadde til oppgave å undersøke barrierer for etablering og utvikling av sosialøkonomiske virksomheder i Danmark og gi anbefalinger om hvordan disse utfordringer best kunne møtes. Regjeringen fulgte i september 2014 opp utvalgets anbefalinger ved å lansere en tverrdepartemental innsats for å fremme utviklingen av sosialøkonomiske virksomheter i Danmark.

Blant initiativene er:

- En registreringsordning for sosialøkonomiske virksomheter som gjør det mulig å registrere seg som sosialøkonomisk virksomhet og dermed oppnå en form for godkjentstempling, blant annet i forhold til etterlevelse av et sosialt formål og reinvestering av overskudd.

- Et vekstsenter for sosialøkonomiske virksomheter som skal samle og formidle kunnskap, styrke samarbeidet på feltet og tilby hjelp og veiledning i lover og regler til sosialøkonomiske virksomheter, kommuner og andre aktører.

- Et Råd for Socialøkonomiske Virksomheder som skal følge sektorens utvikling, samt arbeide for et styrket fokus på sosialøkonomiske virksomheter på tvers av offentlig, privat og frivillig sektor.

- Flere initiativ rettet mot å styrke sosialøkonomisk iverksetting og forretningsdrift.

- En informasjonskampanje.

- Utarbeidelse av en verktøykasse for dokumentasjon av sosial effekt som kan støtte og veilede sosialøkonomiske virksomheter til å dokumentere sitt arbeid og sine resultater.

- Tilskudd til styrket kommunal innsats som skal hjelpe spesielt motiverte og interesserte kommuner til å styrke sin innsats for og samarbeide med sosialøkonomiske virksomheter. 
- Private partnerskap - et program som skal fremme etablering og utvikling av partnerskap mellom sosialøkonomiske virksomheter og større danske virksomheter.

- Undersøkelse av muligheten for å lempe på rimelighetskravet for sosialøkonomiske virksomheter. Rimelighetskravet regulerer andelen av ansatte på særlige vilkår i en virksomhet.

\subsection{I hvilken grad fokuserer innsatsene på de fire kjennetegnene ved sosialt entreprenørskap}

Det virker generelt å være god overensstemmelse mellom de danske innsatsene og de fire kjennetegnene ved sosialt entreprenørskap som arbeidsgruppen har lagt til grunn for denne kartleggingen. Når respondentene ble spurt om i hvilken grad deres innsats fokuserer på hvert enkelt kjennetegn, svarer de aller fleste av respondentene "til en viss grad" eller "i stor grad" på alle fire kjennetegn.

Det virker spesielt å være et stort fokus på tverrfaglighet og tverrsektorielt arbeid i de danske innsatsene. Her svarer de aller fleste av innsatsene "i stor grad". Blant våre respondenter svarer noen færre det samme for utvikling og utprøving av nye løsninger, og om lag halvparten svarer at de "i stor grad" har fokus på hhv. involvering av målgruppen og på økonomisk bærekraft.

Figur 6.4. Fokus på kjennetegn

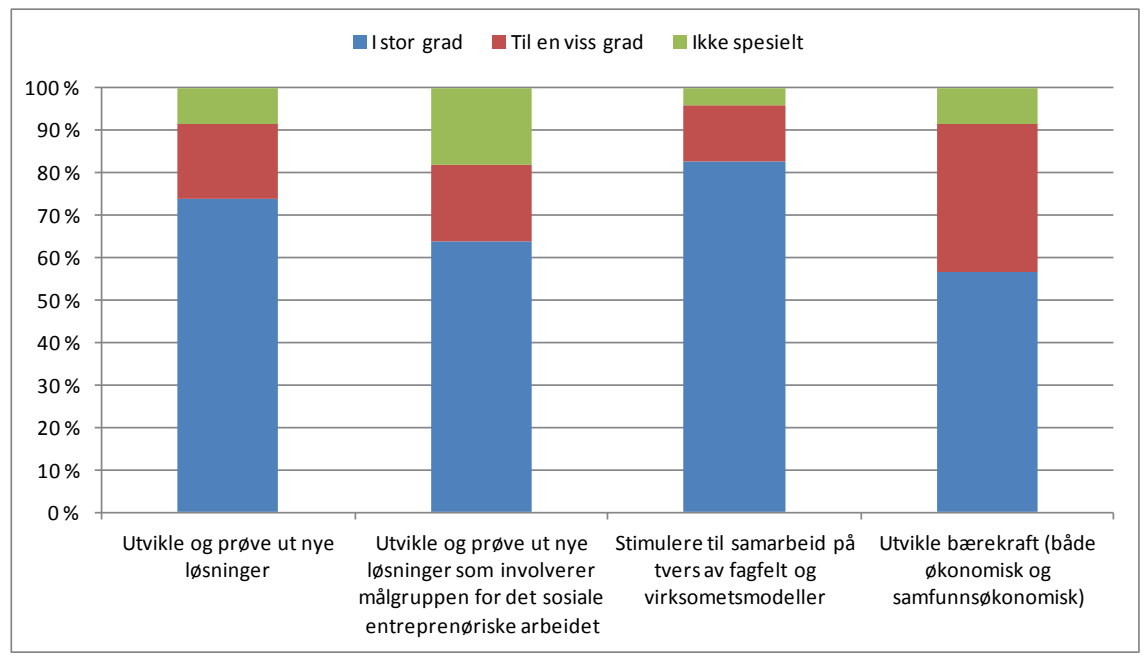




\subsection{Oppsummerende kommentar}

Samlet gir materialet inntrykk av at det for alvor har kommet et fokus på å fremme sosialt entreprenørskap og sosial innovasjon i Danmark først i løpet av de senere år, og at dette fokuset i en viss utstrekning handler om sosialøkonomiske virksomheter, som er en form for sosialt entreprenørskap. Det må imidlertid tas forbehold om at vi gjennom de valg som er tatt underveis, ikke har fanget opp hele bredden og variasjonen av innsatser som finnes, se kapittel 5.1. De offentlige innsatsene synes å være av nyere dato og ha spesielt fokus på den sosialøkonomiske virksomhetsformen, mens innsatsene i sivilsamfunnet tenderer til å ha et bredere og mer generelt fokus på sosial entreprenørskap og/eller sosial innovasjon.

Den nylig igangsatte danske tverrdepartementale innsatsen for å fremme utviklingen av sosialøkonomiske virksomheter synes å være et første eksempel på en koordinert nasjonal offentlige innsats på dette område i Danmark, men kanskje også i Norden. Vel og merke opererer ikke innsatsen direkte med begrepene sosialt entreprenørskap eller sosial innovasjon. 


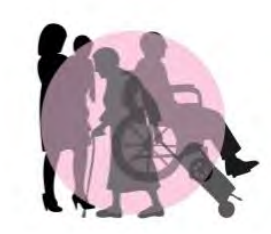

\section{Innsatser for sosialt entreprenørskap og sosial innovasjon i Finland}

\subsection{Innledning}

Begrepene sosialt entreprenørskap, sosial innovasjon og sosiale foretak (sociala företag) er relativt nye i Finland, men har blitt stadig mer benyttet seneste tiårene.

Det har i Finland vært en lang tradisjon for organisasjoner som arbeider for jobb, sosiale tjenester og velferd for sårbare grupper i samfunnet. Disse tradisjonelle tredjesektorsorganisasjoner har vært aktive og produsert sosial innovasjon rettet mot ulike grupper med spesielle behov.

Det har de siste årene blitt utviklet nye former for sosiale og samfunnsmessige foretak (sociala och samhälliga företag) av engasjerte entreprenører, organisasjoner i tredje sektor, kooperativer og stiftelser. Det finnes to ulike former for samfunnsmessig foretak: 1) de som i henhold til lov om sosiale foretak (1351/2003) tilbyr arbeid til personer med nedsatt funksjonsevne og langtidsledige, og 2) de som tilfredsstiller krav til virksomhetsmodellen for et samfunnsmessig foretak og får benytte et bedriftsmerke for slike foretak.

Arbets- och näringsministeriet nedsatte i 2010 en arbeidsgruppe for å vurdere om virksomhetsmodellen for samfunnmessige foretak kan være egnet for å styrke og utvikle entreprenørskap, reformere offentlig tjenesteproduksjon, organisere de frivillige organisasjonenes avgiftsbelagte tjenesteproduksjon og integrere den på arbeidsmarkedet. Arbeidsgruppen peker i sin rapport fra januar 2011 på at det finnes interesse for forretningsmodellen for samfunnsmessige foretak både blant de som $ø$ nsker å bli entreprenører, blant foretak som allerede eksisterer og blant frivillige organisasjoner. Gruppen foreslo med dette som utgangspunkt å utvikle denne modellen videre, og pekte i denne sammenheng på betydningen av å definere kjennetegn ved denne modellen som skiller den fra foretakenes samfunnsansvar og allmenn veldedighet.

Som på andre områder i Finland, forventes sosiale og samfunnsmessige foretak å forbedre kvaliteten på offentlige tjenester, skape innova- 
sjoner, forbedre produktiviteten og ha en forebyggende effekt på sosialog helseproblemer.

De europeiske strukturfondenes program og prioriteringer har spilt en viktig rolle i forhold til å støtte og styre utvikling av sosiale og samfunnsmessige foretak i Finland.

Selv om det i Finland har utviklet seg ulike former av sosiale og samfunnsmessige foretak, er det fremdeles uklart hvilken rolle og posisjon disse foretakene skal ha i det finske samfunnet.

I følge det nåværende regjeringsprogrammet skal lov om sosiale foretak gjennomgås, og dette arbeidet har nylig startet opp.

Begrepet økosystem blir i stadig i større grad brukt om strukturer som støtter oppstart og utvikling av sosiale og samfunnsmessige foretak. Man kan si at slike strukturer er i ferd med å etableres.

I det følgende presenteres resultatene fra kartleggingen i Finland.

\subsection{Respondentene}

I den finske delen av kartleggingen ble det sendt spørreskjema til 48 aktører som driver virksomhet for å fremme sosialt entreprenørskap og sosial innovasjon. I noen tilfeller har mottakeren spredt spørreskjemaet til medlemsorganisasjoner eller innad i sitt styre. Det medfører at flere enn 48 aktører har fått skjemaet.

\section{Figur 7.1. Sektor}

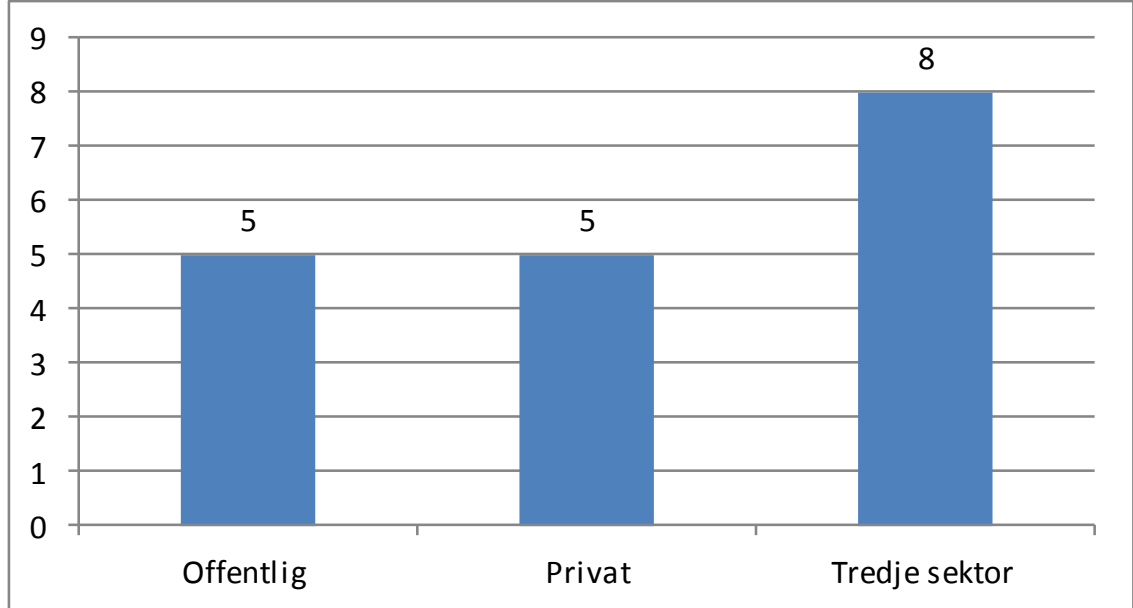


Vi fikk inn svar fra 17 respondenter fra privat, offentlig og tredje sektor. En av respondentene har krysset av for både privat og tredje sektor. Respondentene fra offentlig sektor kommer i hovedsak fra departementer med ansvar for helse- og sosialsaker, kommuner, lokale myndigheter som finansierer Eurpeiska Socialfonden (ESF)-prosjekter og universiteter og høyskoler som arbeider med utvikling av sosiale foretak.

Blant respondenter fra privat sektor er stiftelser, inkubatorer, rådgivningsorganisasjoner og aktører som definerer seg som sosiale entreprenører.

\subsection{Hvilke hovedtyper innsatser er kartlagt}

Respondentene hadde mulighet til å krysse av for flere alternativer som beskriver innsatsenes innretning. Av svarene fremgår det at de fleste respondentene har innsatser innen flere kategorier.

Figur 7.2. Innsatstyper

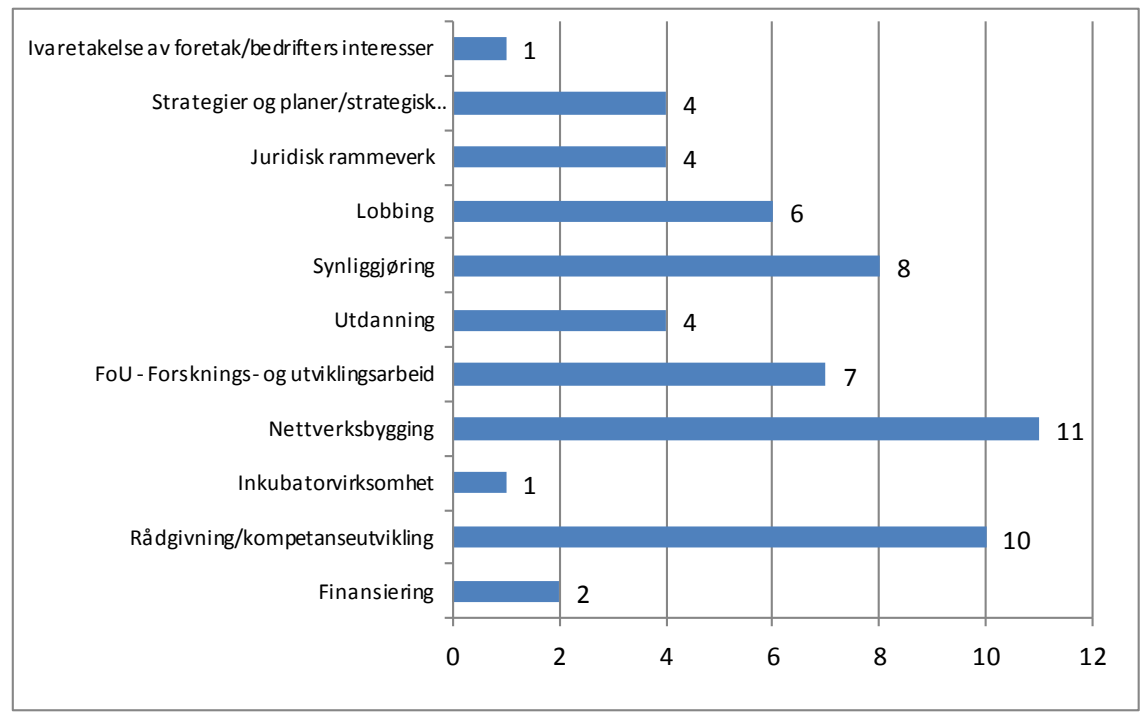

De finske respondentene dekker en stor bredde av innsatser. Synliggjøring, samt nettverksbygging og rådgivning/kompetanseutvikling er de hyppigst forekommende innsatsene. Bare et fåtall driver med inkubatorvirksomhet og ivaretakelse av foretaks/bedrifters interesser. De fleste av disse innsatsene faller sammen med utdanning og opplæring, fremme av foretakenes samfunnsansvar og bærekraftig utvikling, og finansiering og støtte til foretak. Det finnes også innsatser som omfatter 
lobbing, nettverksbygging, opplæring, rådgivning og utvikling, samt tilbud om utdanningsopplegg, undersøkelser og rapporter, i tillegg til kommunikasjon gjennom ulike kanaler.

Nesten alle innsatser har karakter av å være prosjekt og er dermed avgrenset i tid. Det er likevel slik at en og samme aktør ofte viderefører den prosjektorganiserte virksomheten gjennom å utvikle konseptet i nye prosjekter.

I noen tilfeller har også den regionale fordelingen og målgruppen blitt avgrenset på samme måte.

Et eksempel på dette er Sällskapet Pellervo som har til oppgave å fremme og spre økonomisk kooperasjon i Finland. Dette innebærer blant annet å være talsmann for kooperativ utdanning på alle utdanningsnivå og lobbe for kooperasjoner både i Finland og internasjonalt. Et annet eksempel er Arvoliitto (Värdeförbund), som er en lobbyorganisasjon som arbeider med samfunnsforetak og fremmer deres interesser.

\subsection{I hvilken grad er dette nye innsatser}

Et flertall av innsatsene har blitt utviklet de siste ti årene. Noen av disse er nylig grunnlagt. Enkelte innsatser har eksistert over lengre tid, som for eksempel Sällskapet Pellervo fra og med 1899.

\subsection{Hva er formål og målgruppe for innsatsene}

Svarene på spørsmål om formål og målgruppe for innsatsene kan deles inn i følgende tre kategorier, som også beskriver formålet for samfunnsmessige foretak:

- Innsatser som fremmer og støtter sysselsetting og entreprenørskap i samsvar med regjeringsprogrammet.

- Innsatser som forsterker samfunnsmessige foretaks økosystem.

- Innsatser for å inkludere utsatte grupper i arbeid og samfunnsliv.

Innsatser som fremmer og støtter sysselsetting og entreprenørskap i samsvar med regjeringsprogrammet

I denne kategorien finner vi oppgaver og virksomhet som faller sammen med gjennomføringen av det nåværende regjeringsprogrammet og som fremmer og støtter sysselsetting og entreprenørskap i Finland. Blant disse er ett forsøk med arbeidsbanker på nasjonalt plan, et prosjekt i 
regjeringsprogrammet som det er satt av bevilgninger til for hele regjeringsperioden, samt virksomheten innenfor strukturfondprogrammet Hållbar Tillväxt och Hållbara Jobb.

\section{Innsatser som forsterker samfunnsmessige foretaks økosystem}

Vi finner her aktører og aktiviteter som støtter samfunnsmessige foretak gjennom å styrke deres økosystem og øke allmenn kunnskap. Blant disse finner vi: 1) Kasvuhuone, 2) SEE4M, 3) forsterkning av de forretningsmessige forutsetningene for sosiale kooperativ, 4) innsatser for utvikling av forretningsmessige forutsetninger for arbeidstrening og lokalsamfunn for sosiale tjenester, 5) nettverksbygging og innsats for å fremme forsknings- og utviklingsvirksomhet knyttet til samfunnsmessige foretak, 6) et nettverk som har til oppgave gjennom lobbing å fremme bærekraftig utvikling og sosiale innovasjoner i større foretak, i mindre foretak også ved hjelp av deres interessegrupper.

Regionale prosjekter som forsterker entreprenørskap i samfunnsmessige foretak og miljøet rundt, der man ofte også utarbeider forskjellig lære- og informasjonsmateriell tilknyttet emnet, og forsterker for eksempel kunnskapen om forretningsvirksomhet gjennom utdanning og kursing, kan også falle inn under denne kategorien. Det er også prosjekter som utreder forutsetninger for hvordan entreprenørskap innen samfunnsmessige foretak skal kunne tilby løsningsmodeller for sysselsetting av personer som har vanskelig for å skaffe seg arbeid, muligheter for å sikre lokale tjenester på landsbygda, samt ulike nye serviceløsninger.

Innsatser for å inkludere utsatte grupper i arbeid og samfunnsliv Innenfor denne kategorien finner vi innsatser som har rehabilitering og arbeidsinkludering av grupper med spesielle behov som mål, herunder utviklingshemmede og andre som har en svak posisjon på arbeidsmarkedet. 


\subsection{Hvordan er innsatsene finansiert}

Vi hadde delt inn i fire kategorier på forhånd, samt en "annet" kategori dersom respondenten hadde utfyllende svar. Vi fant følgende i vårt materiale:

\section{Figur 7.3. Finansieringskilder}

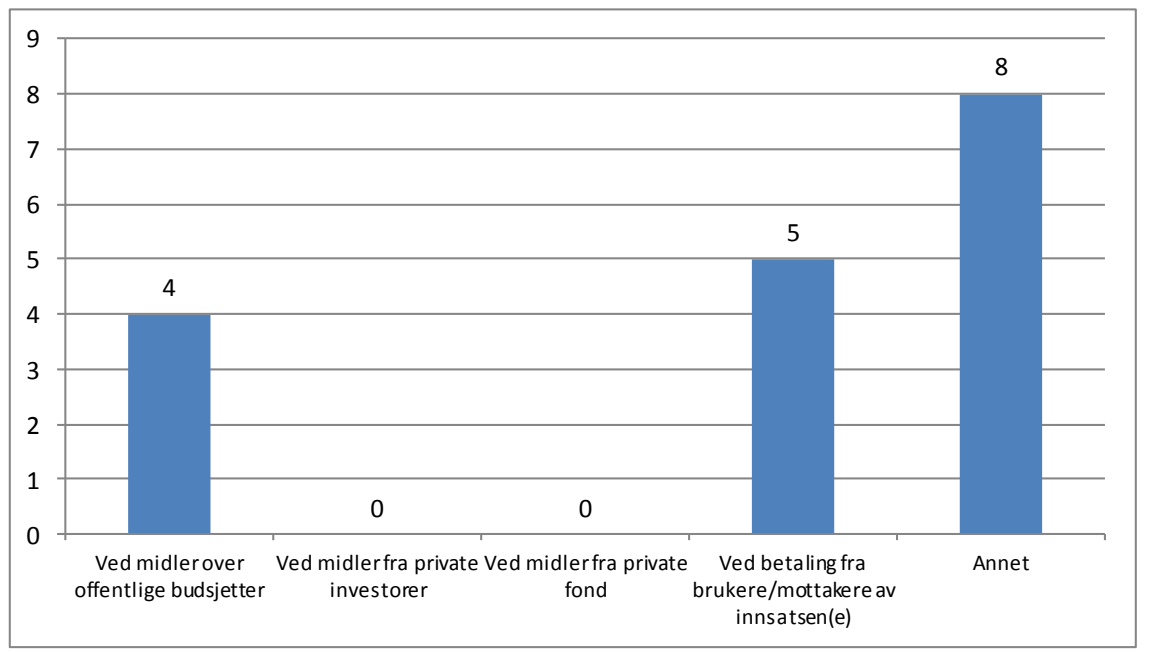

Innsatsene finansieres gjennom flere finansieringskilder, men i hovedsak gjennom å kombinere ulike (offentlige) finansieringskilder: Bidrag, støtte, serviceavtaler og Eurepeiska Socialfonden (ESF) prosjektfinansiering, men delvis også i form av betaling fra brukere av innsatsene. Ut fra svarene har det ennå ikke i høy grad utviklet seg et marked for private investorer eller fond i Finland.

\subsection{Hvordan legger innsatsene til rette}

\section{Finansiering}

Det finnes så langt ikke mange finansieringsinnsatser i privat regi for å utvikle samfunnsmessige foretak i Finland. Typiske innsatser for å finansiere slike foretak har vært ulike prosjekter finansiert av Europeiska Sosialfonden (ESF). Disse har innbefattet tiltak for utvikling av bærekraftige samfunnsmessige foretak. De sosiale og samfunnsmessige foretakene benytter samme finansieringskilder som andre typer foretak. 


\section{Rådgivning/kompetanseutvikling}

Det forutsettes normalt at samfunnsmessige foretak benytter de samme offentlige tjenestene for foretak som andre foretak benytter. Metoder for rådgivning og kompetanseutvikling av samfunnsmessige foretak i Finland baserer seg også på ulike regionale Europeiska Socialfonden (ESF) finansierte utviklingsprosjekter.

I disse prosjektene har man utviklet og forsterket samfunnsmessige foretaks økosystem, og utarbeidet ulike typer lære- og informasjonsmateriell med tilknytning til emnet, og bidrar blant annet til økt kunnskap om forretningsvirksomhet gjennom utdanning og læring. Dette har også inkludert blant annet kurs, konferanser og workshops.

\section{Nettverksbygging}

Det finnes ulike spredte nettverk av/for samfunnsmessige foretak, men disse er også derfor relativt svake.

Ti ulike aktører som er aktive innen samfunnsmessige foretak etablerte nylig (2014) Alliansen Arvo (betyr verdi på norsk). Alliansen Arvo støtter sosiale foretak og deres forretningsvirksomhet. Arvo arbeider for $ø$ kt kunnskap om samfunnsmessige og verdibasert foretak og deres prestisje. Alliansens virksomhet har som mål å styrke strukturene for et sosialt og økologisk holdbart samfunn.

Alliansen samarbeider med næringsliv, myndigheter og andre interessenter for å sikre samfunnsmessige foretaks forretningsvirksomhet. Formålet er å skape en positiv utviklingspiral for sosialt entreprenørskap, eksempelvis gjennom å skape nye finansieringsmodeller. Alliansen Arvo er en sammenslutning av sosiale foretak, samt andre sammenslutninger for næringspolitiske spørsmål.

\section{FoU - Forsknings- og utviklingsarbeid}

FinSERN er det finske forskningsnettverket for de samfunnsmessige foretakene. FinSERN oppsummerer og sprer internasjonal og finsk forskning, holder kontakt med fagområdets forskere og forskningsnettverk ute i verden, samt kartlegger og informerer om finansieringsmuligheter, aktuelle hendelser, pågående forskning og publiserte artikler fra forskning innen fagområdet.

FinSERN er et forskningssamfunn der forskere med interesse for samme emne og de som benytter kunnskapen, kan møtes. FinSERN vil inspirere og motivere forskere og alle de som studerer temaet ved ulike høyskoler og universitet til å bygge internasjonale nettverk. FinSERN åpner dører til høyskoler og universiteter rundt om i verden og kartlegger publiseringskanaler for forskere. 
Det finnes i det innsamlede materialet ingen innsatser som er direkte rettet mot sosialt entreprenørskap og sosial innovasjon, men likevel allerede fra begynnelsen av 2000-tallet eksempler på forskningprosjekter som var direkte rettet mot sosial innovasjon. Det finske kulturfondet har også i samarbeid med flere universitet et Argumenta-projekt om sosial innovasjon osv.

\section{Utdanning}

Det finnes ikke noen utdanningsprogram rettet inn mot samfunnsmessige foretak, men det finnes ulike kurs ved enkelte universitet og høyskoler. En voksenopplæringsinstitusjon innen folkeopplysning har utviklet utdanningsmateriale og et internettbasert kurs om samfunnsmessige foretak.

\section{Juridisk rammeverk}

Et eksempel på juridisk rammeverk er lov om sosiale foretak og merket for samfunnsengasjerte foretak.

Lov om sosiale foretak definerer sosiale foretak på følgende måte:

Ett socialt företag är en näringsidkare som är registrerad i registret över sociala företag:

1) som införts i handelsregistret i enlighet med ovan nämnda lag.

2) som producerar nyttigheter enligt företagsekonomiska principer.

3) av vars anställda arbetstagare minst 30 procent är sådana personer som avses i $1 \S 1$ punkten eller sammanlagt minst 30 procent sådana personer som avses i $1 \S 1$ punkten och andra personer som avses i $1 \S$ (andel sysselsatta), och (28.12.2012/924).

4) som till alla sina anställda arbetstagare, oberoende av dessas produktivitet, betalar lön på basis av full arbetsförmåga enligt det kollektivavtal som tillämpas i branschen i fråga, eller, om ett sådant kollektivavtal inte finns, betalar gängse och skälig lön för arbetet i fråga.

Sociala företag enligt denna lag erbjuder arbetsmöjligheter i synnerhet åt personer.

1) som har en skada eller sjukdom som försvårar deras sysselsättning,

2) som har varit arbetslösa arbetssökande utan avbrott i tolv månader eller som i flera perioder av arbetslöshet har varit arbetslösa arbetssökande i sammanlagt minst tolv månader och på grundval av upprepad arbetslöshet och den tid arbetslösheten totalt har varat kan jämställas med arbetssökande som utan avbrott varit arbetslösa i tolv månader. 
3) som har fătt arbetslöshetsförmån på grund av arbetslöshet under minst 500 dagar.

Merket for samfunnsmessige foretak bevilges av Kommisjonen for samfunnmessige foretak. Foretakene som mottar et slikt merke har gjennomgått en helhetsanalyse med vekt på de tre primærkriteriene for samfunnsmessige foretak, men også av andre egenskaper som vurderes som sentrale ved slike foretak.

De tre primærkriteriene for samfunnsmessige foretak er:

- Ett samhälleligt företags primära uppgift och målsättning är att producera välfärd i samhället. Ett samhälleligt företag bedriver en ansvarsfull affärsverksamhet.

- Begränsad vinstutdelning. Samhälleliga företag använder, i enlighet med sin affärsidé, största delen av sin vinst till att producera samhälleig välfärd, genom att utveckla sin verksamhet, eller genom att donera vinsten $\mathrm{i}$ enlighet med denna.

- Affärsverksamhetens öppenhet och transparens. För att säkerställa transparensen, måste företaget, som ansöker om märket förbinda sig att lägga företagets samhälleliga målsättning och begränsade vinstudelning till sin bolagsordning eller sina stadgar.

Sosiale foretak er et virkemiddel for arbeidsinkludering av personer som har vansker med å komme inn på det åpne arbeidsmarkedet. Sosiale foretak produserer varer og tjenester for markedet og etterstrever økonomisk gevinst på sammen måte som andre foretak. Et sosialt foretak kan drive sin virksomhet inn hvilken som helst bransje.

Det som skiller sosiale foretak fra andre foretak er at minst 30 pst av de ansatte i et sosialt foretak skal være personer med nedsatt funksjonsevne eller personer som både er funksjonshemmede og langtidsarbeidsløse. Foretaket skal i tillegg være registrert i registeret for sosiale foretak opprettet av Arbets- och näringsministeriet, og bare foretak registrert i dette registeret kan anvende benevnelsen sosialt foretak og et emblem i sin forretningsvirksomhet og markedsføring, jf lov om sosiale foretak (1351/2003).

Per juni 2014 finnes det 89 sosiale foretak i dette registeret. Høsten 2014 overveide Arbets- och näringsministeriet enten å fornye eller avskaffe loven om sosiale foretak i Finland. 
Strategier og planer/strategisk utviklingsarbeid, ivaretakelse av foretaks/bedrifters interesser, synliggjøring og lobbing

Fire av respondentene svarte at de arbeider med strategier og planer. Seks nevner lobbing og 10 ivaretakelse av foretaks interesser. Åtte nevner at de arbeider med synligjjøring. Det er imidlertid vanskelig å identifisere konkrete eksempler på hvordan respondentene arbeider med dette. Et eksempel som kan likevel nevnes her er den tidligere nevnte Alliansen Arvo.

\subsection{I hvilken grad fokuserer innsatsene på de fire kjennetegnene ved sosialt entreprenørskap}

\section{Utvikle og prøve ut nye løsninger}

Følgende oversikt viser hvordan respondentene har svart på spørsmålet om i hvilken grad de har fokus på å utvikle og prøve ut nye løsninger.

Figur 7.4. Utvikle og prøve ut nye løsninger

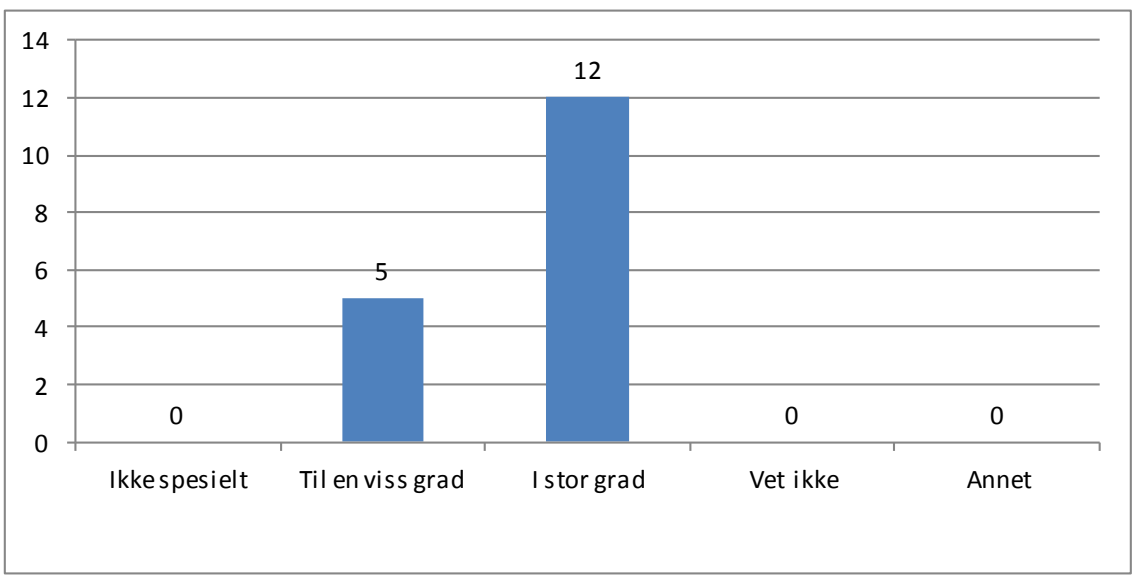

En stor andel av respondentene svarte at de "i stor grad" har fokus på å utvikle og prøve ut nye løsninger, alle svarer at de enten "til en viss grad" eller "i stor grad" har fokus på dette.

Nye (lokale) løsninger forsøkes ofte utviklet gjennom konkrete forsøk, og man søker ofte etter løsninger for målgrupper med spesielle utfordringer, for eksempel når det gjelder å finne arbeid. Utgangspunktet for forsøket er ofte å skape en økonomisk bærekraftig virksomhetsmodell. 


\section{Målgruppeinvolvering}

I kartleggingen var vi også opptatte av i hvilken grad respondentene involverer målgruppen:

Figur 7.5. Utvikle og prøve ut nye løsninger som involverer målgruppen for det sosiale entreprenøriske arbeidet

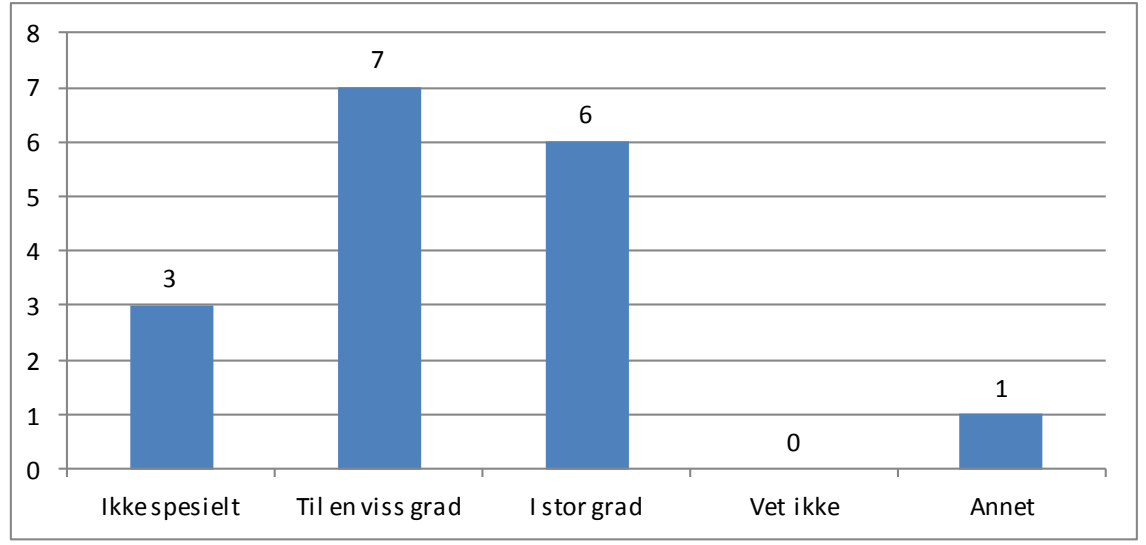

En stor andel av respondentene svarer at de "til en viss grad" eller " $\mathrm{i}$ stor grad" har fokus på å utvikle nye løsninger som involverer målgruppen for det sosialentreprenøriske arbeidet. Gjennom ulike former for partner- og nettverkssamarbeid forsøker man å få til sosialt og økonomisk holdbare løsninger som har en positiv innvirkning på målgruppens stilling. I noen av løsningene har man benytter metoder for tjenestedesign.

\section{Samarbeid på tvers av fagfelt og virksomhetsmodeller}

Sosialt entreprenørskap og sosial innovasjon omtales også som fenomener som er genuint opptatt av nye samarbeidsformer på tvers av etablerte strukturer. Vi var derfor opptatte av å identifisere nærmere hvordan respondentene selv plasserte seg i forhold til dette. 
Figur 7.6. Stimulerer til samarbeid på tvers av fagfelt og virksomhetsmodeller

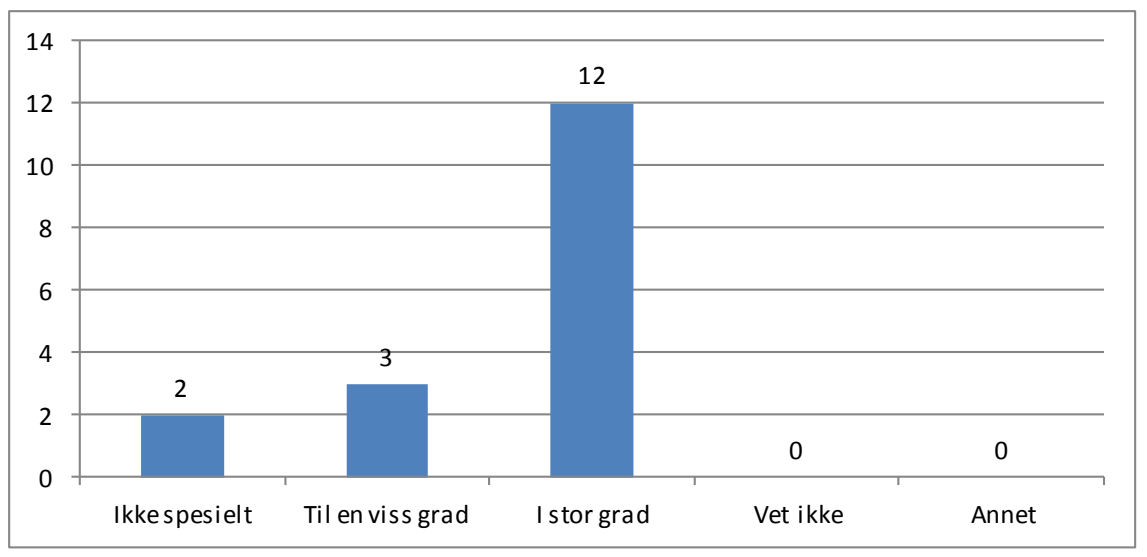

Et stort flertall av respondentene svarer også at at de "i stor grad" har fokus på samarbeid på tvers.

De fleste av innsatsene gjennomføres og drives i et variert nettverksog partnersamarbeid. Viktige samarbeidspartnere er ulike regionale offentlige miljøer, høyskoler og læreinstitusjoner som støtter og fremmer sysselsetting og entreprenørskap, samt bransjeorganisasjoner.

Respondentene innser i prinsippet at et sosialt bærekraftig samfunn krever et svært omfattende samarbeid med nettverk innen ulike forvaltnings- og yrkesområder. Sosiale innovasjoner anses å oppstå i gjensidig samarbeid med ulike aktører. I følge svarene støtter og benytter ulike aktørers nettverk seg av en slik virksomhetsmodell.

\section{Bærekraft (både økonomisk og samfunnsøkonomisk)}

Vi stilte spørsmål om både økonomisk og samfunnsøkonomisk bærekraft. Følgende oversikt viser hvordan respondentene selv svarer på dette.

Figur 7.7. Utvikle bærekraft, både økonomisk og samfunnsmessig

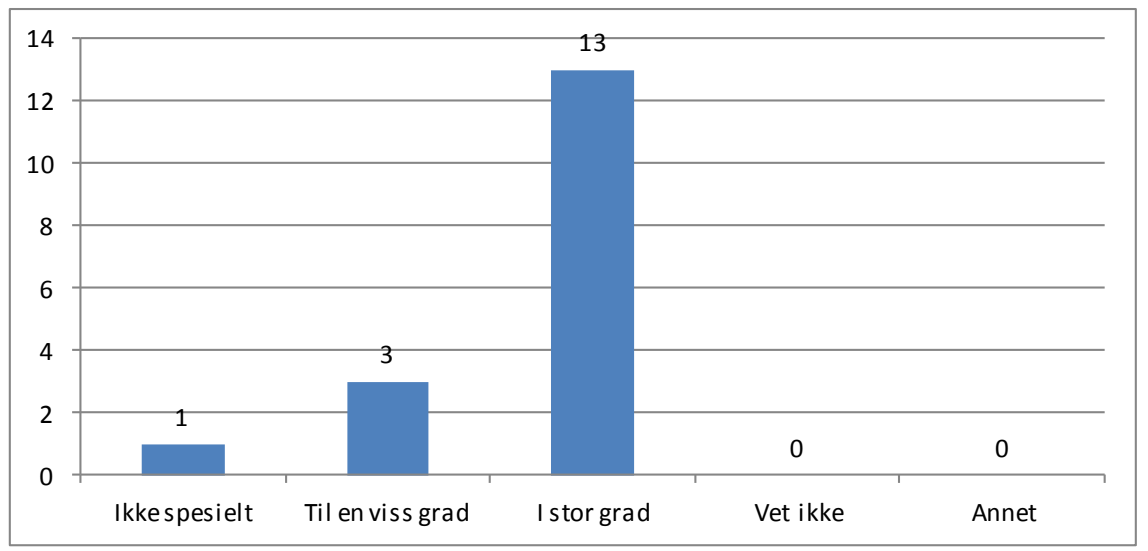


Som det framgår av figuren svarer også et stort flertall av respondentene at de "i stor grad" har fokus på å utvikle bærekraft både økonomisk og samfunnsmessig. De økonomisk og samfunnsmessige bærekraftige løsningene finnes i aktørenes særegne kjennetegn.

\subsection{Oppsummerende kommentar}

Det har i Finland nylig vært nedsatt en arbeidsgruppe i Arbets- og näringsministeriet som har hatt sosiale foretak som tema. Likevel savnes en felles klar visjon for hvilken rolle og mandat disse foretakene skal ha i det finske samfunnet. Dette gjelder både i forhold til utvikling av sosialog velferdstjenester, men også i forhold til aksept av nye foretaksmodeller fra tradisjonelle aktører på markedet. Det finnes samtidig tradisjonelle tredjesektor organisasjoner som har en etablert rolle i markedet som sosiale foretak strever etter.

Begrepene sosialt entreprenørskap og sosiale foretak er relativt nye i Finland, men har blitt stadig mer etablert i seneste tiårene. Det er i ferd med å utvikles et økosystem av sosiale foretak og deres interesseorganisasjoner, forskernettverk og rådgivning. ${ }^{28} \emptyset$ kokosystemet er under utvikling og er foreløpig svakt og sårbart. Det er lite kunnskap om sosiale foretak og det finner heller ikke egne utdanningsprogram med dette som tema ved høgskoler og universitet.

Nettverksbygging i miljøet hjelpes ikke av at forvaltningsområdet er preget av dyp sektorisering og mangel på samarbeid, på riks-, forvaltnings- og lokalforvaltningsnivå. Desentralisering av virksomheten til ulike forvaltningsområder medfører at ingen aktører ser saken som helt sin egen. Det er liten interesse blant aktører med ansvar for forretningsvirksomhet, for samfunnsvirksomhet.

Det er behov for regionale, fasiliterende fora, som er aktivt innrettet mot brukerorientert utvikling av nye servicemodeller der kommuner, virksomheter og frivillige organisasjoner sammen utvikler nye løsninger. En av løsningene kunne være å bygge opp kompetansesentrum, nå er informasjonen og kompetansen svært fragmentert.

\footnotetext{
${ }^{28}$ Se også Briitta Koskiaho, Kumppanuuden sosiaalipolitikkaa etsimässä, United Press global, 2014, ss 159-172; 187-195.
} 
Man kan vurdere det slik at det finnes mangel på målrettet forretningsrådgivning eller at nåværende system for forretningsrådgivning er for lite fleksibelt.

Det er behov for utvikling av rådgivningstjenester for foretak, slik at de omfatter foretakets samfunnsmessige perspektiver og ulike juridiske reguleringers egnethet for de ulike formål tjenestene har, samt utdanning for forretningsrådgivere.

Før det må man identifisere og erkjenne ulik kunnskap i nettverket.

Et av de største hindrene for å utvikle samfunnsforetak er sviktende eller manglende tilgang på fungerende instrumenter for finansiering. Man kan si at finansieringsløsninger for samfunnsforetak er lite utviklet i Finland. Det kreves mer fleksible finansieringsløsninger og mer langsiktige finansieringsinstrumenter, for eksempel ulike modeller av "impact investment".

Til tross for at loven om sosiale foretak og et stempel for samfunnsengasjerte foretak finnes i Finland, er det behov for videre utvikling av det juridiske rammeverket. Juridisk rammeverk må utvikles for å åpne muligheten for fleksible veier inn i arbeidslivet og for nye måter å handle på for foretak. 


\section{A}

\section{Innsatser for sosialt entreprenørskap og sosial innovasjon i Island}

\subsection{Innledning}

Sosialt entreprenørskap og sosial innovasjon er relativt ukjent i Island. Selv om disse begrepene er kjent for noen, er dette ikke begreper som folk flest er kjent med og benytter. Det finnes ingen egne initiativ og innsatser som er spesielt rettet mot sosialt entreprenørskap og sosial innovasjon. Men hvis en tar utgangspunkt i definisjonene av sosialt entreprenørskap og sosial innovasjon i litteraturen, er det likevel klart at flere aktører og aktiviteter, spesielt i tredje sektor, men også blant mer uformelle grupper, kan kategoriseres som dette. Forskning har vist at tredje sektor i Island er dypt forankret i velferdssystemet. Sektoren spiller en omfattende rolle i levering av velferdstjenester, hvorav noen kan kategoriseres som sosial innovasjon. ${ }^{29}$

Noen av støtten til aktiviteter på dette feltet, og da spesielt til innsats for å integrere marginale grupper i samfunnet, har blitt etablert etter 2008 i etterkant av finanskrisen i Island. Annen støtte har vært gitt i mange år.

Det finnes ingen forskning med sosialt entreprenørskap og sosial innovasjon som tema, og det undervises heller ikke i sosialt entreprenørskap og sosial innovasjon på universiteter.

Det er mange initiativ, diskusjoner og politisk interesse for entreprenørskap generelt, som oftest knyttet til tekniske løsninger, men det har ikke vært politisk interesse for sosialt entreprenørskap og sosial innovasjon, kanskje fordi diskusjonen om dette først har nådd landet ganske nylig.

I det følgende presenteres funn fra Island.

29 Ómar H. Kristmundsson and Steinunn Hrafnsdóttir (2012). The Role of Non-profit organizations in the development and provision of welfare services in Iceland. Moving the Social. Journal of Social History and the History of Social Movements. 48, 179-192. 


\subsection{Respondentene}

Spørreskjemaet ble sendt til 19 aktører i Island. I alt 13 svarte på spørreskjemaet. To svarte at de ikke yter noe relevant støtte. Responsraten er relativt god, men det var også noen viktige organisasjoner som gir støtte til entreprenører som ikke svarte på spørreskjemaet.

Siden det i Island ikke er vanlig å bruke begrepene sosiale entreprenør eller sosial innovasjon, var det vanskelig å finne aktører som kun yter støtte til sosiale entreprenører eller som bruker dette begrepet. Spørreskjemaet ble derfor sendt til aktører som gir støtte til entrepren $\varnothing$ rer generelt, inkludert sosiale entreprenører. Ulike organisasjoner og aktiviteter i sivilsamfunnet har i lang tid bidratt med nye løsninger på ulike sosiale utfordringer, herunder for ekskluderte grupper.

Som vist i figuren under, tilhører de fleste av aktørene i vårt materiale offentlig sektor. Vi har kartlagt en i privat sektor og tre i tredje sektor.

\section{Figur 8.1. Sektor}

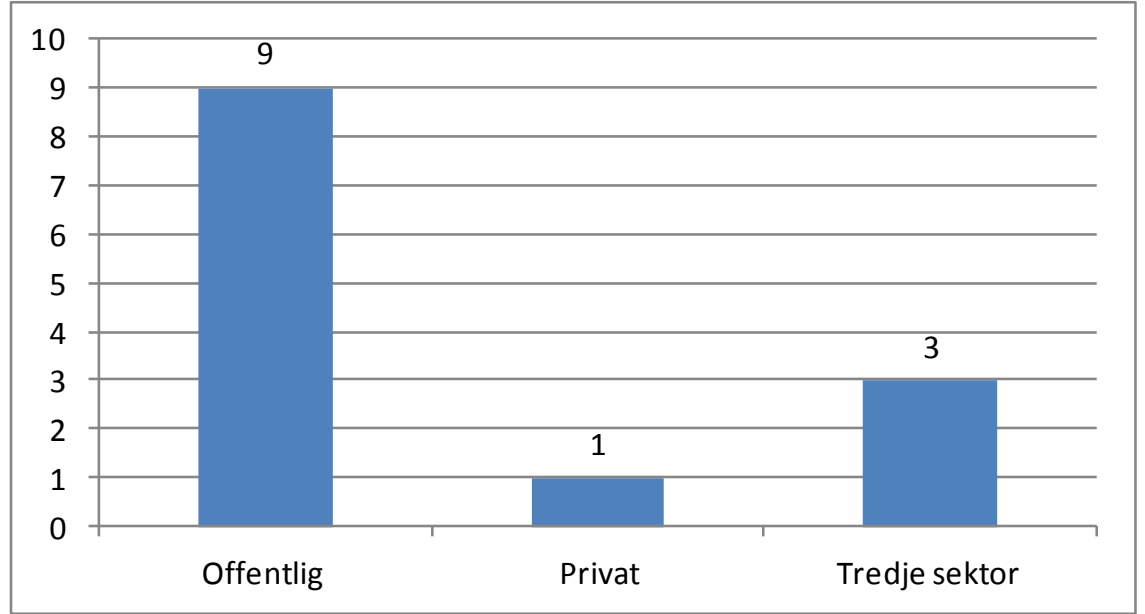

\subsection{Hvilke hovedtyper innsats er kartlagt}

Respondentene fra offentlig sektor kommer i hovedsak fra offentlige organisasjoner og offentlige fond som støtter entreprenøraktivitet generelt, men også sosiale entreprenører. Den eneste respondenten fra privat sektor arbeider i hovedsak med inkubatorvirksomhet, mens respondentene fra tredje sektor er non-profit organisasjoner som bidrar med nettverksbygging, lobbing og i noen tilfeller støtte til entreprenører generelt. En av tredjesektor organisasjonene yter tjenester spesielt for ekskluder- 
te grupper i arbeidsmarkedet, inkludert støtte til entreprenører og sosiale innovasjonsaktiviteter. Ingen av respondentene definer seg selv som sosiale entreprenører eller bruker begrepet sosial innovasjon.

Figur 8.2. Innsatstyper

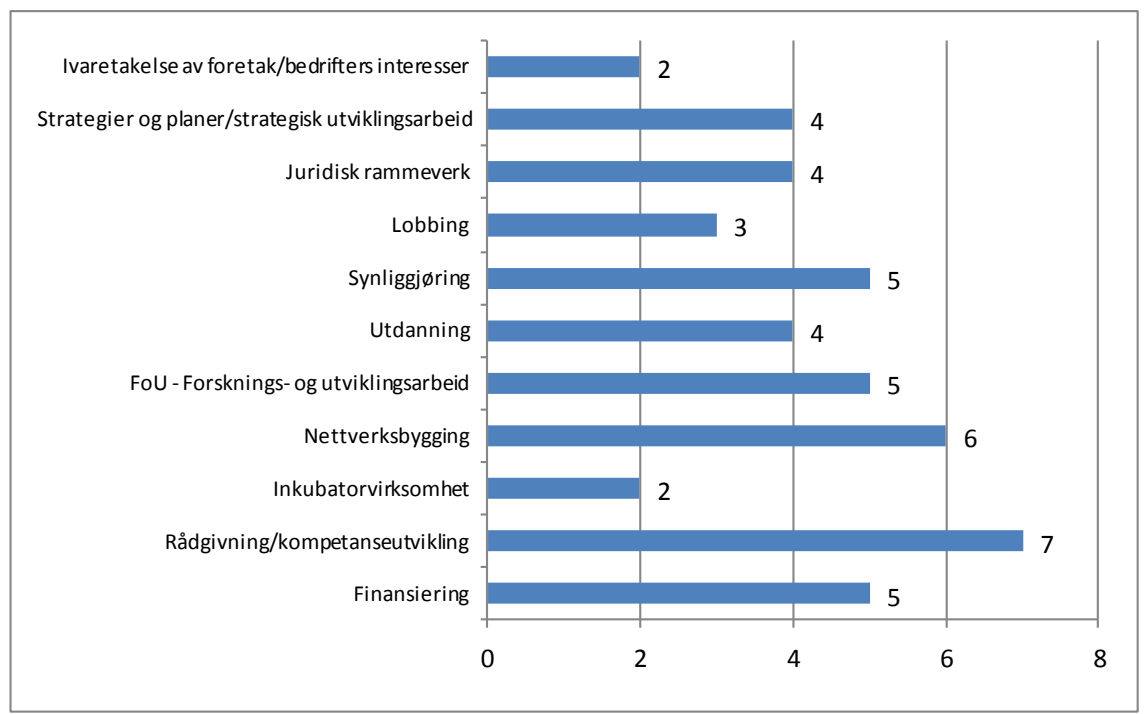

Det framgår av vårt materiale at de fleste innsatsene tilhører mer enn en kategori. Et flertall av respondentene har markert for to kategorier eller mer. Det fremgår av figuren over at de fleste respondentene gir råd og kompetanseutvikling i form av utdanning, kurs, pro-bono tjenester etc. Nettverksbygging nevnes av seks organisasjoner, og fem organisasjoner har innsatser innen forskning og utvikling, synliggjøring og finansiering (som tilskudd, lån, risikokapital etc.). Fire aktører har innsatser knyttet til utdanning, lov- og regelverk, strategier og planer. Bare tre nevner lobbing og to nevner ivaretakelse av interesser.

For å gi et eksempel på variasjonen av innsatser i Island, kan The Innovation Center of Iceland nevnes. Senteret er en offentlig finansiert organisasjon som yter de mest omfattende tjenestene til islandske entreprenører generelt, inkludert sosiale entreprenører. Senteret kombinerer blant annet workshops, profesjonell støtte til entreprenører, inkubatortjenester og støtte til utviklingsprogrammer. Noe av arbeidet er rettet spesielt mot enkeltgrupper i samfunnet, eksempelvis kvinner som er entreprenører og arbeidsledige (i samarbeid med Directorate of Labour), 
og det ytes tilskudd til innovasjonsprosjekter og markedsføring knyttet til oppstart av nye virksomheter som kan bidra til å skape jobber. ${ }^{30}$

Et annet eksempel er Virk Vocational Rehabilitation Fund (VIRK) som er en privat stiftelse tilhørende tredje sektor, hvor alle store fagforeninger og arbeidsgivere er medlemmer. VIRK arbeider med å utvikle, integrere og overvåke tjenester på området yrkesrettet rehabilitering ut fra målet om sysselsetting for personer etter sykdom eller skade. Målet er å gi støtte i vid forstand både til utvikling og innovasjon. Det legges også stor vekt på informasjon og utdanning både for arbeidsgivere og enkeltpersoner. VIRK gir tilskudd til å utvikle nye løsninger og til forskningsprosjekter. De kjøper også tjenester fra ulike tilbydere av velferdstjenester, som for eksempel frivillige organisasjoner og enkeltpersoner, som da får en mulighet til å utvikle og teste innovative måter å tilby yrkesrettet rehabilitering på. ${ }^{31}$

Det er også eksempler på respondenter som i hovedsak bidrar med finansiering i form av tilskudd og i noen tilfeller spesielle servicekontrakter. Et eksempel er Ministry of Welfare som yter tilskudd innenfor flere velferdsområder, for eksempel til sysselsetting for kvinner og $\varnothing k t$ deltakelse fra personer med nedsatt funksjonevne i samfunnet, samt tilskudd til forskning og utvikling på feltet flyktninger og innvandrere. Det viktigste målet for denne støtten er å bidra til at marginaliserte grupper øker sin deltakelse i samfunnet, synliggjøre bidraget fra disse gruppene og styrke kvinners entreprenøraktivitet.

Tredjesektor organisasjoner, enkeltpersoner, og i noen tilfeller forskere, kan søke på disse tilskuddene. De er ikke øremerket for sosiale entreprenører. 32

\subsection{I hvilken grad er dette nye innsatser}

Som tidligere nevnt er det er ingen innsatser i Island som bruker begrepene sosialt entreprenørskap eller sosial innovasjon. Noen innsatser av relevans for arbeidet med å inkludere utsatte grupper i arbeid og samfunnsliv har blitt etablert etter finanskrisen i Island i 2008. Andre har vært i drift i flere år. Som et eksempel kan nevnes Virk Vocational Rehabilitation fund (VIRK) som ble etablert i 2009 (se omtale over), og Directorate of Labour

\footnotetext{
${ }^{30}$ www.nmi.is

31 www.virk.is

32 www.vel.is
} 
som etter 2008 etablerte flere ulike programmer for å skape nye jobber og støtte arbeidsløse som ønsket å starte nye virksomheter. Noen av disse programmene kan defineres som sosial innovasjon. ${ }^{33}$

\subsection{Hva er formål og målgruppe for innsatsene}

I vårt materiale retter innsatsene seg i mange tilfeller mot et vidt spekter av formål og målgrupper. I andre tilfeller er målene og innsatsene mer presise. Derfor er det i noen tilfeller vanskelig å klassifisere innsatsene. Det må nevnes at vi i våre data fra Island ikke kan se at innsatsene bruker begrepene sosial innovasjon og sosialt entreprenørskap. I mange tilfeller brukes imidlertid ord som innovasjon, entreprenørskap, integrering av ekskluderte grupper og sivilsamfunn/non-profit.

I det følgende vil vi bruke følgende kategorier til å organisere dataene:

- Innsatser som støtter sosialt entreprenørskap og sosial innovasjon for å integrere ekskluderte grupper i arbeid og samfunnsliv.

- Innsatser som støtter sosialt entreprenørskap og sosial innovasjon generelt.

- Innsatser for å integrere ekskluderte grupper i arbeid og samfunnsliv generelt.

- Innsatser med andre formål.

Innsatser som støtter sosialt entreprenørskap og sosial innovasjon for å integrere ekskluderte grupper i arbeid og samfunnsliv

Et mindretall av respondentene svarer at de spesielt støtter integrering av ekskluderte grupper i samfunnslivet. Ingen av disse benytter begrepene sosialt entreprenørskap og sosial innovasjon i beskrivelsen av sin innsats, selv om innsatsene absolutt kan sies å legge til rette for dette i følge definisjoner i litteraturen, se kapittel 3.

Et eksempel er Virk rehabilitation fond (VIRK), som er tidligere nevnt. Et annet eksempel er Directorate of Labour som rapporterer til Ministry of Welfare. Directorate of Labour bistår ulike vankeligstilte grupper med å komme inn på arbeidsmarkedet eller skaffe arbeid for personer med spesielle behov. Ett eksempel på dette er www.tower50plus.eu som tilbyr

${ }^{33}$ www.vinnumalastofnun.is 
utdanning i entreprenørskap for personer 50 år eller eldre slik at de kan etablere egne virksomheter, og aktivering av unge arbeidsløse personer 16-29 år som tilbyr muligheter for arbeid, utdanning eller annen aktivitet for inkludering i arbeid og samfunnsliv. ${ }^{34}$

Et tredje eksempel er Ministry of Welfare som tilbyr ulike tilskudd til aktører i sivilsamfunnet for å integrere ekskluderte grupper i samfunnet (se tidligere omtale).

\section{Innsatser som støtter sosialt entreprenørskap og sosial innovasjon generelt}

Det er mulig å finne generelle innsatser som stimulerer til sosialt entreprenørskap og sosial innovasjon i Island. Dette er imidlertid også innsatser som støtter andre typer entreprenørskap, entreprenører eller organisasjoner i tredje sektor, hvorav noen kan defineres som sosiale innovatører.

The Innovation Center of Iceland, omtalt tidligere, har bidratt med noe materiale til sosiale entreprenører og vært vertskap for en konferanse om dette emnet. Noen av senterets innsatser fremmer sosial innovasjon og sosialt entreprenørskap, selv om disse begrepene sjelden brukes. Et annet eksempel er The Innovation Public Sector Website lansert av University of Iceland som en arena for allsidig informasjon om innovasjon $\mathrm{i}$ offentlig sektor. Hovedmålet er å etablere et nettverk som oppmuntrer til og støtter entreprenøraktiviteter. ${ }^{35}$

Et tredje eksempel er the Association of the Third Sector in Iceland. Dette er en paraplyorganisasjon for aktører i tredje sektor i Island, inklusive medlemsorganisasjoner og non-profit virksomheter som arbeider for allmennyttige formål. ${ }^{36}$

\section{Innsatser for å integrere ekskluderte grupper i arbeid og samfunnsliv}

Siden det så langt vi kjenner til, ikke finnes noen innsatser som bruker begrepene sosialt entreprenørskap eller sosial innovasjon, kan alle eksempler fra den første kategorien også nevnes her. Det er likevel flere innsatser som støtter integrering av ekskluderte grupper i arbeid og samfunnsliv generelt. Vi kunne her nevne ulike organisasjoner i tredje sektor som arbeider med rehabilitering, og ulike private og offentlige fond som støtter alle typer aktiviteter overfor grupper som er ekskludert fra ar-

\footnotetext{
34 www.vinnumalastofnun.is/heim/

35 www.nyskopunarvefur.is

${ }^{36} \mathrm{http}$ //www.almannaheill.is/heim/
} 
beids- og samfunnsliv. For å nevne noen eksempler fra våre data på respondenter som kan plasseres under denne kategorien, vil vi vise til Directorate of Labour, Ministry of Welfare, samt noen av aktivitetene til the Innovation Centre of Iceland og Virk Rehabilitation Fond (VIRK).

\section{Innsatser med andre formål}

Det finnes også eksempler i vårt materiale på mer generell støtte til integrering og inkludering av ekskluderte grupper. Et eksempel er Public Health Fund, der hovedmålet er å støtte og promotere folkehelse og forebygging. Enkeltpersoner og frivillige organisasjoner kan søke om finansiell støtte til spesielle prosjekter og til forskning. I mange tilfeller har disse tilskuddene blitt gitt til sosiale entreprenører eller frivillige organisasjoner som arbeider for å fremme utsatte gruppers integrering og inkludering på arbeidsmarkedet. ${ }^{37}$ Et annet eksempel er Youth Fund og Ministry of Education. Hovedformålet til dette fondet er å støtte spesielle prosjekter drevet av ungdomsorganisasjoner eller -foreninger, tilrettelagt for barn og ungdom, eventuelt med deres aktive deltakelse. ${ }^{38}$

\subsection{Hvordan er innsatsene finansiert}

Som det fremgår av figuren under, er de fleste innsatsene i vårt materiale finanisert med offentlige midler. En respondent har rapportert egenbetaling fra brukerne, mens fire repondenter har svart "annet".

37 http://www.landlaeknir.is/um-embaettid/lydheilsusjodur/

38 www.mnr.is 
Figur 8.3. Finansieringskilder

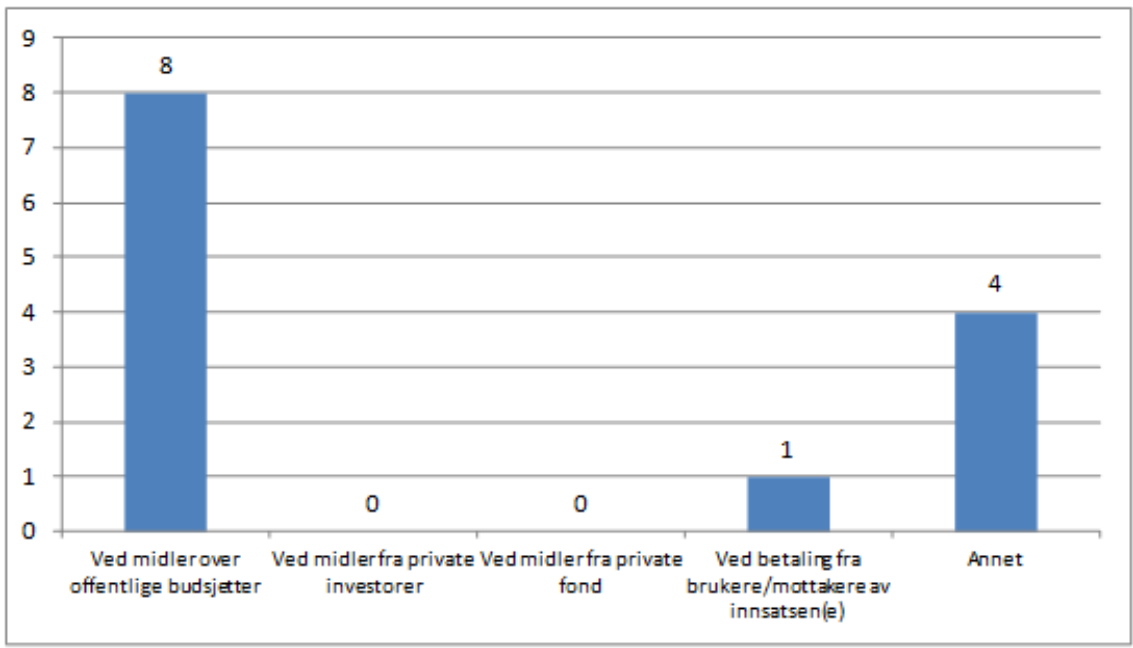

\subsection{Hvordan legger innsatsene til rette}

I det følgende vil vi gi eksempler på hvordan innsatsene kan sies å støtte sosialt entreprenørskap og/eller sosial innovasjon selv om mange av disse også gir støtte til alle entreprenører.

\section{Finansiering}

Eksempler på innsatsen finansiering er tilskudd og lån som vanligvis gis etter søknad. Det er fastsatt regler for hvem som kan søke om hva, og tilskudd og lån gis vanligvis for en avgrenset periode, oftest ett år. Når prosjektet er gjennomført, skal det sendes inn en sluttrapport. I noen tilfeller kreves også rapportering underveis i prosjektet.

Et eksempel er tilskudd fra Ministry of Welfare til integrering av marginaliserte grupper i samfunnslivet. Et annet eksempel er Public Health Fund som har som mål å støtte og fremme folkehelse og forebygging i vid forstand, herunder for marginaliserte grupper.

\section{Rådgiving/kompetanseutvikling}

Rådgivning/kompetanseutvikling kan være workshops, konferanser, forskning, veiledning, konsultasjoner, trening, personlig veiledning og erfaringsutveksling etc. Eksempler på aktører som tilbyr denne typen innsats er The Innovation Center of Iceland, se tidligere omtale, og Directorate of Labour som bidrar med alle typer rådgivning og kompetanseutvikling for arbeidsledige. 


\section{Inkubatorvirksomhet}

Det er to eksempler på inkubatorvirksomhet i de islandske dataene.

Den ene er Klak/Innovit Entrepreneurship Centre som er en virksomhet eid av flere ulike offentlige og private organisasjoner. Senteret har som hovedmål å hjelpe personer til å starte opp nye virksomheter og iverksette nye ideer. Senterets arbeider på ulike måter. De har workshops, kurs, rådgivning, finansiering og mentoring. De kan også sørge for kontorfasiliteter for møter eller konferanser, og et eget forum for å bringe investorer og entreprenører sammen. De arrangerer også en årlig konkurranse, The Golden Egg, som også er for sosiale entreprenører.

Det andre eksemplet er det tidligere nevnte The Innovation Center of Island. Innovasjonssenteret driver et eget senter i organisasjonen, Impra, som støtter oppstart av nye virksomheter og tilbyr fasiliteter innen innovasjon for bedrifter i oppstartsfasen. Senterets mål er å stimulere til innovasjon og utvikling av nye ideer i den islanske økonomien gjennom aktiv deltakelse fra både entreprenører og næringsliv. En gruppe av spesialister fra forskjellige områder stimulerer til innovasjon og utvikling av nye ideer gjennom forskning, utviklingsprosjekter, næringslivsutvikling og profesjonell råd og veiledning.

\section{Nettverksbygging}

I vårt materiale finner vi mange eksempler på innsatser som legger til rette for eller støtter nettverksbygging. Dette arter seg på flere måter, klart definerte nettverk eller mer ad-hoc grupper som er etablert i ulike organisasjoner, spesielt innenfor inkubatortjenestene som er nevnt tidligere. Her er det også mulig å nevne workshops, seminarer etc. Et eksempel på et klart definert nettverk er Association for Entrepreneurs and Innovators in Iceland, som er et støttenettverk innenfor dette feltet. Et annet nettverk er Association of The Third Sector in Iceland, som er et nettverk og en paraplyorganisasjon for aktører i tredje sektor i Island.

\section{Forskning og utviklingsarbeid (FoU)}

Noen av innsatsene i vårt materiale bidrar med tilskudd til forskning på dette feltet. Et eksempel på dette er Rannis- The Icelandic Centre for Research, som er en offentlig organisasjon som støtter forskning, innovasjon, utdanning og kultur i Island. Det er imidlertid vanskelig å finne flere eksempler på dette i vårt datamateriale, selv om det fremgår at støtte til forskning inngår i noen av innsatsene.

\section{Utdanning}

På universitetsnivå er det ikke noe eget program for sosialt entreprenørskap eller sosial innovasjon. Det blir imidlertid undervist i ulike kurs 
om entreprenørskap, innovasjon og non-profit organisasjoner ved flere ulike fakulteter ved University of Iceland. Det finnes også et eget senter for forskning på frivillig sektor, Centre for Third Sector Research ved The School of Social Sciences at the University of Iceland.

\section{Juridisk rammeverk}

Det er få respondenter som svarer at de arbeider med lov- og regelverk. Dette er imidlertid et arbeidsområde for både the Ministry of Welfare, the Ministry of Education and the Ministry of Industry and Innovation. Noen aktører har også svart at de gir råd og veiledning i forhold til lovog regelverk. Dette kan for eksempel være råd om hvordan man etablerer en virksomhet, skatteregler, registrering av virksomheter etc.

\section{Strategier og planer, synliggjøring, lobbing og ivaretakelse foretaks/bedrifters interesser}

Fire av våre respondenter svarer at de tilbyr støtte for strategi og planlegging, tre nevner lobbing og to nevner ivaretakelse av interesser for organisasjoner eller foretak. Fem nevner at de støtter aktivitet for bedre synliggøøring. Som et eksempel på støtte til strategi og planlegging kan vi nevne Icelandic Innovation Centre og Klak/Innovit.

Foreningen for entreprenører og innovatører og Foreningen for frivillige organisasjoner er etablert for å drive med lobbing på vegne av sine medlemmer i Island.

\subsection{I hvilken grad fokuserer innsatsene på de fire kjennetegnene ved sosialt entreprenørskap}

På bakgrunn av arbeidsgruppens forståelse av viktige kjennetegn ved sosialt entreprenørskap, ble det stilt spørsmål om i hvilken grad innsatsene har fokus på utprøving og utvikling av nye løsninger, målgruppeinvolvering, samarbeid på tvers av sektorer og virksomhetsmodeller og bærekraft (økonomisk og samfunnsøkonomisk).

Respondentene i vår undersøkelse ble stilt ett forhåndsstrukturert spørsmål om hvilken vekt innsatsene la på dette, og de fikk også muligheten til å svare mer detaljert om vektleggingen i fire åpne spørsmål.

Det synes generelt å være generelt god overensstemmelse mellem de islandske innsatsene og kjennetegnene arbeidsgruppen har vektlagt ved sosialt entreprenørskap. På spørsmålet om i hvilken grad deres innsatser fokuserer på hvert enkelt kjennetegn, svarer langt de fleste respondenter "til en viss grad" eller "i stor grad" på alle fire kjennetegn. Særligt 
synes det å være stort fokus på på å stimulere til samarbeid på tvers mellom fagfelt og virksomhetsmodeller. Her svarer tre fjerdedeler av respondentene "i stor grad". Under gis en oppsummering av svarene.

\section{Utvikle og prøve ut nye løsninger}

I alt ni av våre respondenter svarte at de "i stor grad" legger vekt på utprøving og utvikling av nye løsninger, og tre svarte at dette "i noen grad" er tilfelle, se figuren under.

Figur 8.4. Utvikle og prøve ut nye løsninger

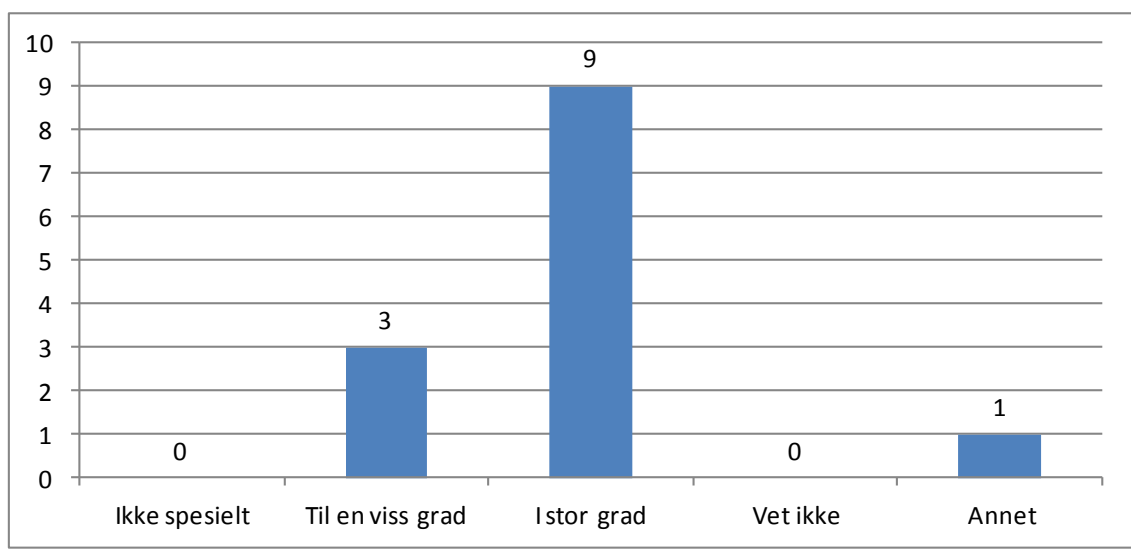

\section{Målgruppeinvolering}

Åtte av våre respondenter svarte at de "i stor grad" har fokus på involvering av målgruppen for entreprenørskap i utviklingen av nye løsninger, tre svarte "i noen grad" og en svarte "vet ikke".

Figur 8.5. Utvikle og prøve ut nye løsninger som involverer målgruppen for det sosialentreprenøriske arbeidet

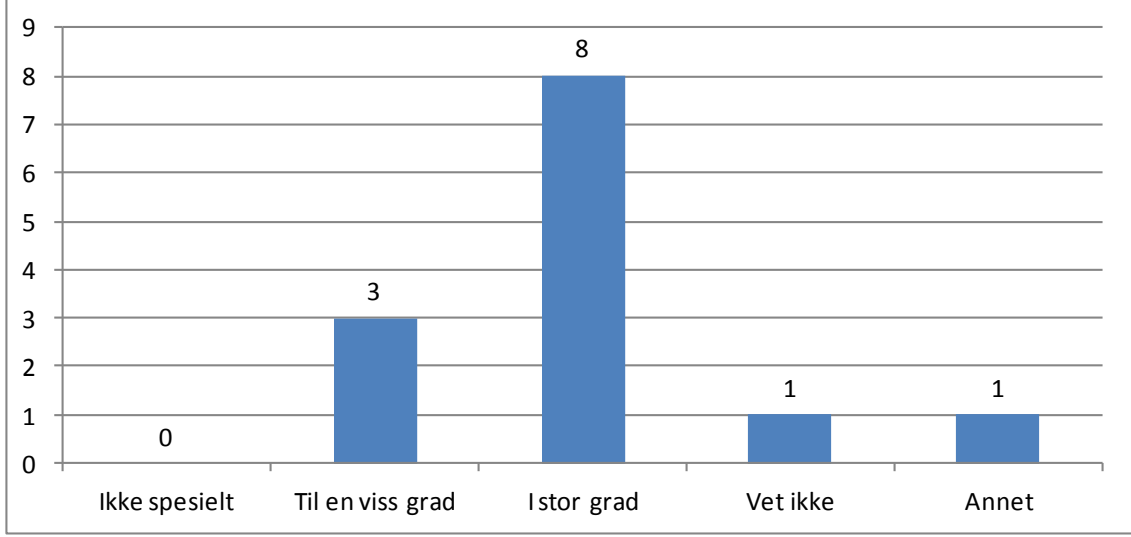




\section{Samarbeid på tvers av fagfelt og virksomhetsmodeller}

En majoritet av respondentene (10) svarte at deres innsats "i stor grad" har fokus på å støtte samarbeid på tvers av sektorer og virksomhetsmodeller, en svarte "ikke spesielt" og en "til en viss grad", se figuren under.

Figur 8.6. Stimulere til samarbeid på tvers av virksomhetsmodeller

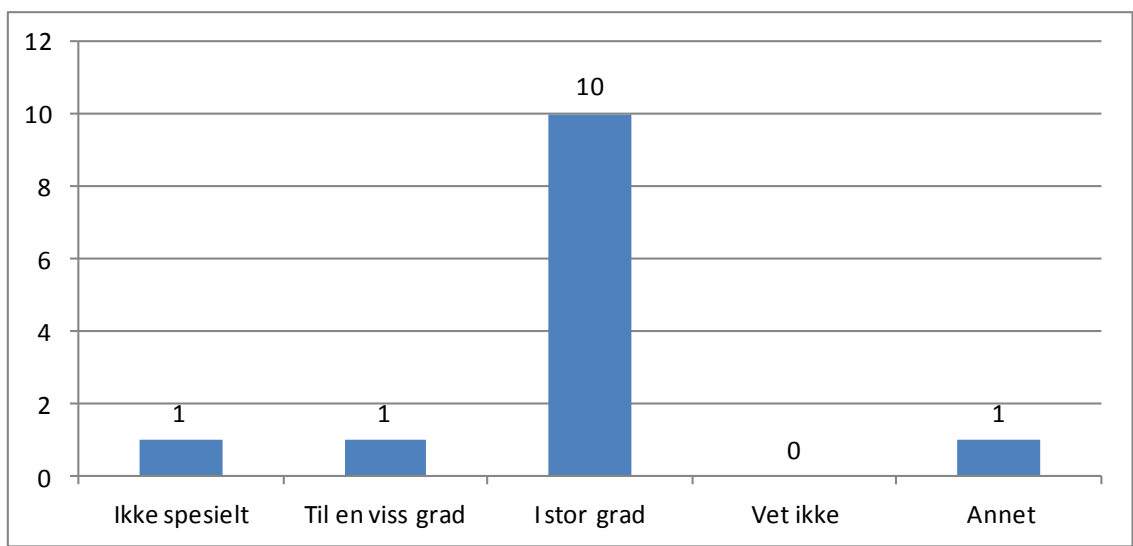

Utvikle bærekraft (både økonomisk og samfunnsøkonomisk)

I alt seks av våre respondenter svarte at de i stor grad legger vekt på å utvikle bærekraft, både økonomisk og samfunnsøkonomisk. Tre svarte "til en viss grad", to "ikke spesielt", mens en svarte "vet ikke", se figuren under.

Figur 8.7. Utvikle bærekraft, både økonomisk og samfunnsøkonomisk

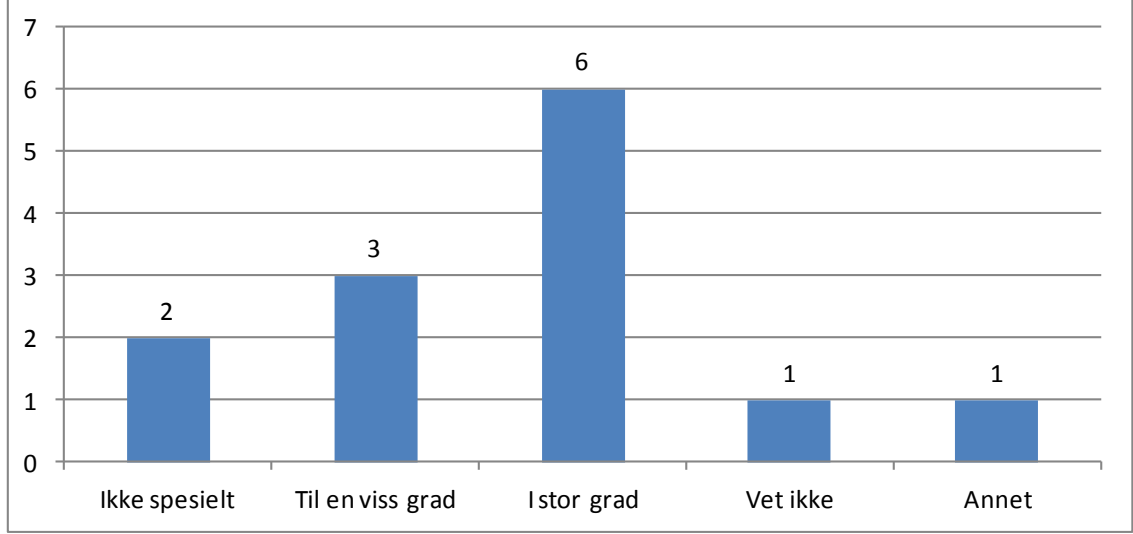




\subsection{Oppsummerende kommentar}

Resultatene fra kartleggingen gir innsikt i støttestrukturene for sosiale entreprenører og sosial innovasjon i Island. Som nevnt i innledningen, er støttestrukturene vanligvis rettet inn mot entreprenører generelt (inkludert sosiale entreprenører) eller frivillige organisasjoner, der noen kan kategoriseres om sosiale entreprenører. Etter finanskrisen ble noe av innsatsen rettet spesielt mot sårbare grupper for å forsøke å integrere dem i arbeid og samfunnsliv. Disse initiativene har imidlertid ikke blitt omtalt som sosial innovasjon, selv om mange av dem kan sies å være det.

Vi kan ikke konkludere med at det ikke finner innsatser for å legge til rette for sosiale entreprenører eller sosial innovasjon i Island, det finnes i høyeste grad. Likevel står ikke terminologien, diskusjonen, forskning, utdanning og initiativ for sosiale entreprenører eller sosial innovasjon høyt på den islandske agendaen ennå. I så henseende ser det ut til at Island henger etter de andre nordiske landene, spesielt siden denne diskusjonen foreløpig ikke har nådd landet vårt. Vårt materiale viser likevel klart at det er ulike former for innsatser som sosiale entrepren $\varnothing$ rer kan gjøre nytte av, som rådgivning, tilskudd, nettverksbygging, fasiliteter, inkubatorvirksomhet, kurs etc. Innsatsene er imidlertid fragmentert og ikke spesielt rettet mot sosialt entreprenørskap. Det som mangler er omfattende tjenester for denne typen aktiviteter, kartlegging og definisjoner, samt en generell politisk diskusjon om disse aktørene og deres forhold til velferdsmodellen i et nordisk perspektiv. 



\section{Innsatser for sosialt entreprenørskap og sosial innovasjon i Norge}

\subsection{Innledning}

I Norge har fremveksten av sosialt entreprenørskap og sosial innovasjon først og fremst vært drevet av enkeltpersoner, virksomheter og investorer. Den politiske interessen for feltet ble synliggjort i 2011 gjennom etablering av et tilskudd til sosiale entreprenører som retter sin innsats mot bekjempelse av fattigdom og sosial eksklusjon. I 2014 ble den økonomiske rammen for dette tilskuddet økt med fem mill kroner til nær åtte mill kroner. Samtidig med etableringen av denne tilskuddsordningen, ble sosialt entreprenørskap også en satsing for en stor investor i Norge. Parallelt med dette vokste det i samme periode fram ulike nettverk, kurs- og utdanningsmuligheter på området.

I dag kan feltet sies å være preget av en økende oppmerksomhet, generelt. Vi ser en økning av virksomheter som betegner seg som sosiale entreprenører, politiske myndigheter har styrket sin og utdanningsinstitusjoner ser ut til å vise økende interesse for området. Regjeringen som tiltrådte høsten 2013, har i sin politisk plattform sagt at den vil bedre betingelsene for bruk av sosiale entreprenører og frivillig sektor i velferdssystemet.

Det er likevel slik at det fortsatt finnes ulike syn og vurderinger i Norge på hvordan feltet og begrepene skal forståes, hva som bør og kan være offentlige myndigheters rolle i dette, og hvordan det i så fall skal tilrettelegges.

I det følgende presenteres materialet fra kartleggingen i Norge. 


\subsection{Respondentene}

Det ble sendt ut spørreskjemaer til i alt 52 aktører i Norge. 37 respondenter besvarte spørreskjemaet.

Det er flest respondenter fra offentlig sektor, dernest følger tredje sektor og privat sektor. En av respondentene har krysset av for både privat og tredje sektor.

Figur 9.1. Sektor

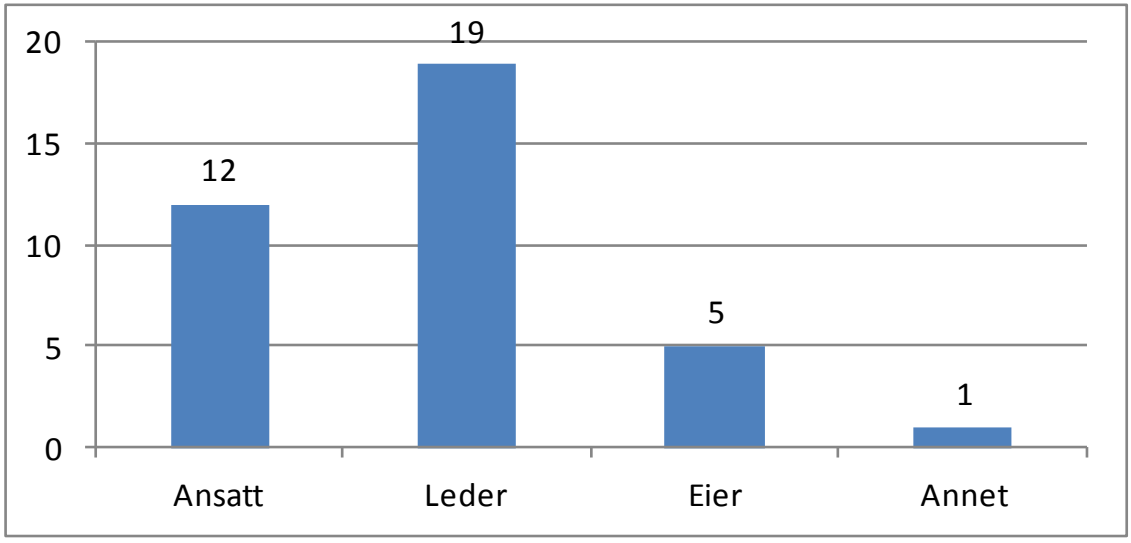

Respondentene fra offentlig sektor kommer i hovedsak fra utdanningsinstitusjoner, sentrale myndigheter og kommuner. Blant respondentene fra privat sektor er både investorer, långivere, tilskuddsforvaltere, stiftelser, fond, inkubatorer og aktører som selv definerer seg som sosiale entreprenører. Blant respondentene i tredje sektor er både frivillige organisasjoner, nasjonale og internasjonale nettverk, inkubatorer, långivere og aktører som definerer seg som sosiale entreprenører.

\subsection{Hvilke hovedtyper innsatser er kartlagt}

I spørreskjema hadde vi forhåndskategorisert en rekke innsatstyper basert på kunnskapen arbeidsgruppen har om temaet. I tillegg ga vi respondentene mulighet for å nedtegne eventuelle andre typer av innsatser, dersom de hadde det. Respondentene kunne krysse av flere innsatstyper. Vi finner følgende oversikt: 
Figur 9.2. Innsatser

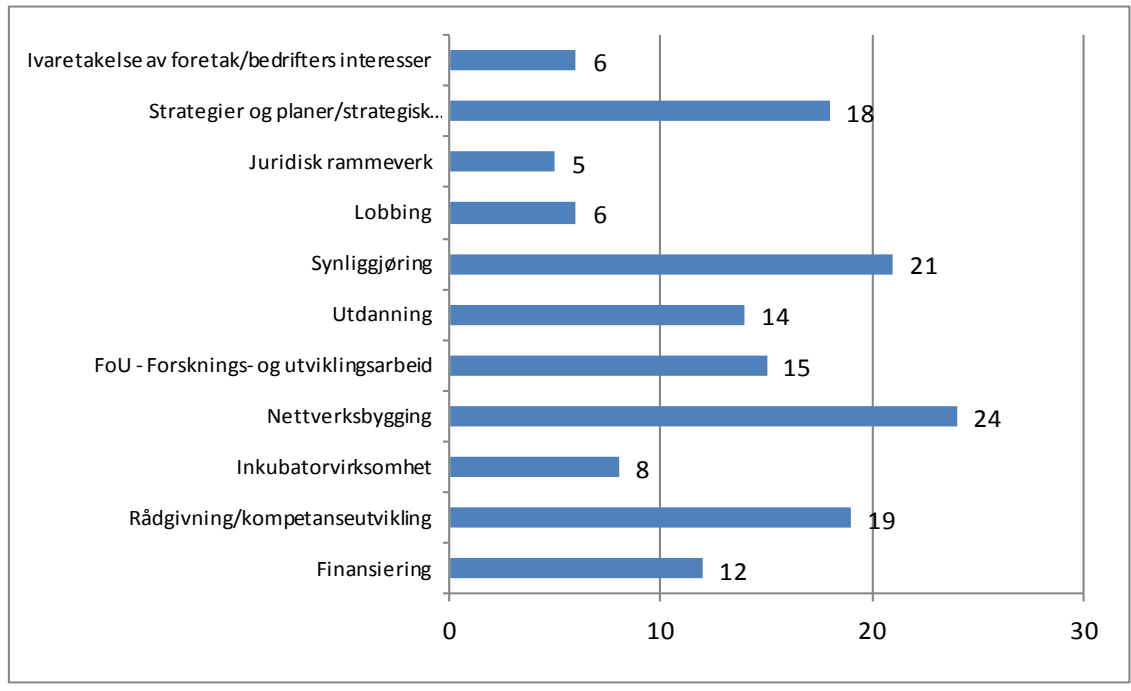

Figuren viser at hovedvekten av respondentene beskriver sin innsats innenfor nettverksbygging, synliggjøring, rådgivning/ kompetanseutvikling og strategier og planer/strategisk utviklingsarbeid.

Alle respondenter har krysset av for minst to typer av innsatser, de fleste for flere enn to, og noen har svart at de tilbyr alle typer innsatser. Finansiering, rådgivning/kompetanseutvikling og nettverksbygging, er den kombinasjonen som er mest utbredt. Ett eksempel på dette er Mikrofinans Norge, som over mange år har gitt lån og veiledning til nyetablerere. ${ }^{39}$ Ett annet eksempel er Ferd Sosiale Entreprenører som kombinerer finansiering, rådgivning/kompetanseutvikling og nettverksbygging koplet med bedriftsutvikling. På hjemmesiden er dette illustrert på følgende måte: 40

\section{Figur 9.3.}

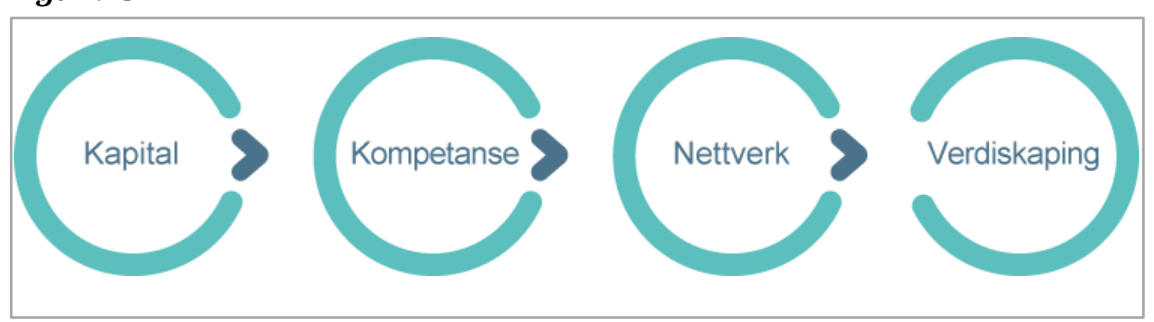

39 http://www.mikrofinansnorge.no/?page_id=9527

$40 \mathrm{http}: / /$ www.ferd.no/sosiale_entreprenorer/investeringsstrategi 
Rådgivning/kompetanseutvikling, nettverksbygging og inkubatorvirksomhet er også en relativt vanlig kombinasjon.

\subsection{I hvilken grad er dette nye innsatser}

De fleste innsatsene som beskrives å være rettet inn mot sosialt entreprenørskap og sosial innovasjon, ble etablert og igangsatt etter 2008, men det finnes også eksempler på innsatser som ble iverksatt tidligere. Det ser ut til at 2009 er en tid da området gikk fra å være nokså ukjent og lite utbredt, til å få både politisk og faglig oppmerksomhet.

\subsection{Hva er formål og målgruppe for innsatsene}

Materialet viser at formål og målgruppe for innsatsene, er formulert på et forholdsvis overordnet nivå. I noen grad finner vi klare mål og målgrupper. I det videre gjennomgår vi materialet med utgangspunkt i fire hovedkategorier.

\section{Innsats for å legge til rette for sosialt entreprenørskap og/eller sosial innovasjon $\mathrm{i}$ arbeidet for å inkludere utsatte grupper $\mathrm{i}$ arbeid og samfunnsliv}

Det er et mindretall av respondenter som svarer at de retter sin innsats mot sosialt entreprenørskap og sosial innovasjon i arbeidet med å inkludere utsatte grupper i arbeidsmarkedet spesielt. Noen er imidlertid tydelige på at dette er målet med innsatsen.

Ett eksempel er Ferd Sosiale Entreprenører som vi tidligere har vist til. Ett annet eksempel er en tilskuddsordning som forvaltes av Arbeidsog velferdsdirektoratet, der målet er å bidra til å bekjempe fattigdom og sosial eksklusjon.

Et tredje eksempel er en aktør som har som overordnet mål å bidra til at flere kommer i arbeid. Denne aktøren, KREM, betegner seg som samfunnsentreprenør og brobygger, og sier følgende om dette i kartleggingen:

Et viktig formål er å synliggjøre kløften mellom behovet for arbeidskraft og tilgjengelig arbeidskraft og være en bro over denne åpne kløften.

Denne aktøren tar også i bruk arbeidskraft som står utenfor ordinært arbeidsliv. 


\section{Innsats for å legge til rette for sosialt entreprenørskap og/eller sosial innovasjon generelt}

Vi finner også eksempler der innsatsene er rettet mot sosialt entreprenørskap og sosiale innovasjon mer generelt.

Et eksempel er Good Business som beskriver seg som et "bedriftsnettverk", der også interesseorganisasjoner, myndigheter og akademia kan dele erfaring og kompetanse knyttet til bedrifters samfunnsansvar.

Av kartleggingen fremgår følgende om kjernen i deres innsats:

Hjelpe bedrifter til å ta ansvarlige valg og bidra til en positiv samfunnsutvikling.

Et annet eksempel er Jan Urban Sandals Institute, som er en privat aktør som tilbyr et sett av innsatser for å fremme sosialt entreprenørskap og sosial innovasjon. ${ }^{41}$ Et tredje eksempel er Høgskolen i Lillehammer som i kartleggingen viser til at de ikke tilbyr:

spesifikt program eller satsingsområde knyttet til sosialt entreprenørskap eller sosial innovasjon, men det er noen utdanningstilbud som har innbakt visse elementer av både sosialt entreprenørskap og sosial innovasjon. ${ }^{42}$

\section{Innsats for å inkludere utsatte grupper $\mathrm{i}$ arbeid og samfunnsliv}

Blant innsatsene som er kartlagt finner vi også eksempler på innsatser som har som formål å inkludere utsatte grupper i arbeid og samfunnsliv, men der dette ikke er direkte knyttet til sosialt entreprenørskap og sosial innovasjon. Ett eksempel på dette er Kronprinsparets fond, som beskriver sin innsats på følgende måte:43

Kronprinsparets Fond skal bidra til at ungdom i Norge har et godt liv, at det blir færre som faller "utenfor", at ungdom tar i bruk egne ressurser - og at deres drømmer går i oppfyllelse. For å få til dette samarbeider Fondet med sosiale entreprenører som alle har ambisjon om å gi unge nye arenaer å lykkes på. Fondet støtter prosjektene økonomisk og med arbeid, produkter og tjenester, i tillegg til å tilby et kompetansenettverk som deler utfordringer og erfaringer med hverandre.

Eksempler på denne typen innsatser finner vi i vårt materiale både i regi av private aktører, banker, stiftelser og fond.

\footnotetext{
${ }^{41}$ http://www.janusandal.no/no/

42http://www.hil.no/forskning/forskningsnyheter/nyheter_2013/program_for_sosialt_entreprenoerskap_ho esten_2013

43 http://kronprinsparetsfond.no/
} 


\section{Andre formål/målgrupper}

Vi finner også eksempler på innsatser som kan bidra til inkludering i arbeidsliv, men der målsettingen er av en mer overordnet og bredere karakter, noe blant annet dette eksemplet fra kartleggingen viser:

Fors $\varnothing$ ksprosjektet Norsk senter for flerkulturell verdiskaping (NSFV) ble etablert i november 2005 av de åtte kommunene i Drammensregionen for å prøve ut en modell for flerkulturell verdiskaping ved å lære opp og veilede talenter til å etablere egne virksomheter. Etter 14 måneders pilotperiode, kunne prosjektet vise til positive resultater i form av bred virksomhet ved senteret, omfattende rådgivning, coaching og kompetanseutvikling av potensielle gründere og bedrifter. Etter endt pilotperiode har senteret videreført sin virksomhet som prosjekt med Buskerud fylkeskommune som eier.

Andre eksempler er Innovasjon Norge, som har økt verdiskaping i norsk næringsliv generelt som formål, ${ }^{44}$ Ungt Entreprenørskap som jobber for å bygge opp entreprenørskapskompetanse hos elever og studenter gjennom hele utdanningsløpet, ${ }^{45}$ og Kavlifondet som beskriver sin innsats som:

Allmennyttige utdelinger til humanitære, kulturelle og forskningsformål. ${ }^{46}$

Vi finner også noen eksempler på at offentlige myndigheter legger til rette for innsatser innen et sosialt område, som for eksempel Husbanken som har fremskaffelse av boliger til vanskeligstilte på boligmarkedet, koordinering av det statlige boligsosiale arbeidet, og kunnskapsutvikling innen boligsosialt arbeid og satsingen "Områdeløft," som mål for sine innsatser. Husbanken gir tilskudd og arbeider med kompetanseheving og rådgivning. ${ }^{4}$

I vårt materiale finner vi også innsatser rettet mot bekjempelse av fattigdom med fokus på barn og unge.

\footnotetext{
${ }^{44}$ http://www.innovasjonnorge.no/, http://www.ue.no/, http://kavlifondet.no/kontakt-oss/

45 http://www.ue.no/

46 http://kavlifondet.no/

47 http://www.husbanken.no/
} 


\subsection{Hvordan er innsatsene finansiert}

Vi hadde forhåndskategorisert i fire kategorier, samt en "annet" kategori dersom respondenten hadde utfyllende svar. På grunn av en teknisk feil ved spørreskjemaet, var det kun var mulig for respondentene å krysse av for ett alternativ på dette spørsmålet.

Vi fant følgende hovedtrekk for alle innsatstyper i vårt materiale:

\section{Figur 9.4. Finansieringskilder}

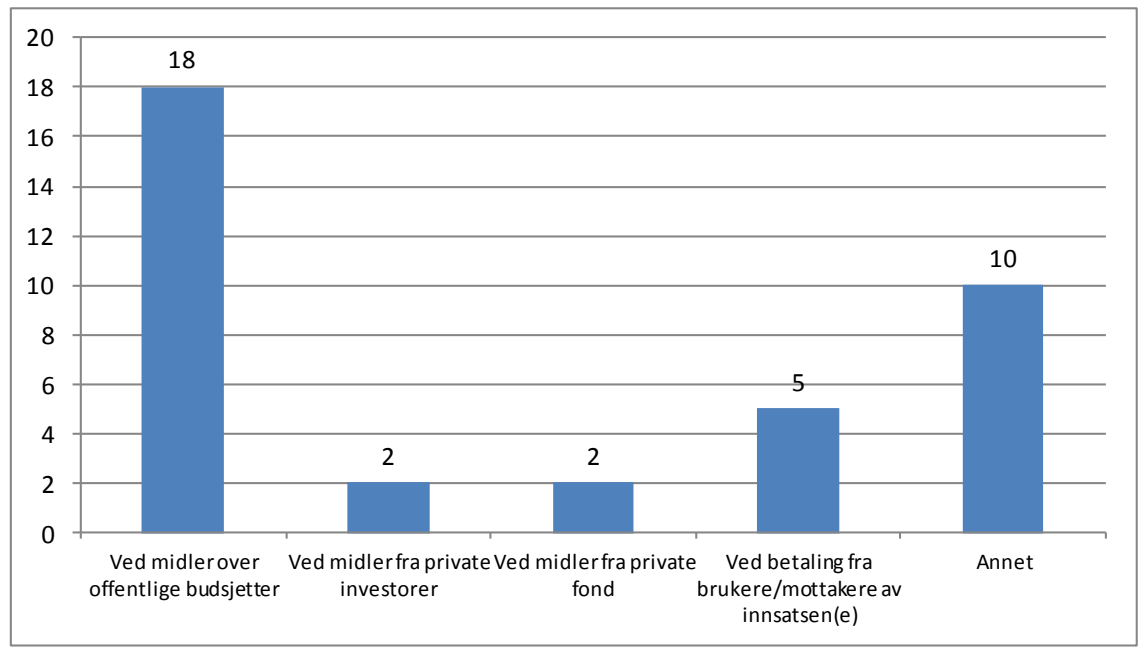

En betydelig overvekt av respondentene rapporterer at de har midler fra offentlige budsjetter. Kategorien "annet", er også relativt høy. Av svarene på de åpne spørsmålene, framkommer det at "annet" dreier seg om salg av tjenester, bruk av egne midler, næringslivssponsing (ikke investering), bruk av egen privat tid, bruk av arbeidstid som "gis" til den aktuelle innsats, bytte av tjenester og pro-bono tjenester. Et eksempel på probono tjeneste er hentet fra vårt materiale, som viser til advokatfirma Schiødt, som selv sier følgende om dette på sin nettside: 48

Av eksempler på samarbeid med privat sektor er vårt partnerskap med et stort konsern der vi tilbyr pro bono-tjenester til individer og mindre selskaper gjennom deres velrespekterte og innovative program for sosialt entreprenørskap.

${ }^{48}$ http://www.schjodt.no/hvem-vi-er/kultur/samfunnsengasjement.aspx 


\subsection{Hvordan legger innsatsene til rette}

Vi vil her presentere eksempler på hvordan innsatsene legger til rette for sosialt entreprenørskap og sosial innovasjon.

\section{Finansiering}

Eksempler på denne typen innsats er lån, tilskudd og fondsbidrag. Den konkrete innsatsen utløses i all hovedsak etter aktiv søknad fra den som ønsker innsatsen. I alle tilfeller stilles det bestemte krav til bruk av finansieringen. Dette kan blant annet være krav til at den som yter innsatsen skal være representert i styret, bedriftsplan, fremdriftsplan og måloppnåelse. I noen tilfeller finner vi at innsatsen åpner for pilotforsøk, der det i en avgrenset periode ikke stilles tydelige krav. Derimot skal det fremgå hva som skal oppnås i pilotperioden. I alle tilfeller er innsatsen av tidsavgrenset karakter. I de fleste tilfeller kan innsatsen fornyes etter søknad, men som hovedregel er det en avgrensning i tid samlet sett.

Et eksempel på finansiering fra en offentlig aktør er Arbeids- og velferdsdirektoratets tilskuddsordning, som omtales slik på nettsiden:

Tilskudd til sosialt entreprenørskap rettet mot bekjempelse av fattigdom og sosial eksklusjon i Norge. Det kan gis tilskudd til virksomheter som bidrar med nye løsninger i arbeidet med å bekjempe fattigdom og sosial eksklusjon.

Det er bevilget nesten 8 millioner kroner til denne ordningen i 2014.49

Et eksempel på finansiering fra privat aktør er Ferd Sosiale Entreprenører. Denne aktøren har et sett av investeringskriterier, der blant annet nyskapning, realistisk, bærekraft, nyttedrevet vekst (skalering) og utvikling er vist til på deres nettside. ${ }^{50}$ Et annet eksempel er Jan Urban Sandals Institute som tilbyr finansiering knyttet til utdanning, kompetanseutvikling og bedriftsrådgivning rettet inn mot sosialt entreprenørskap. Begge disse aktørene følger opp de virksomheter og aktører som mottar tilskudd.

\section{Rådgivning/kompetanseutvikling}

Eksempler på rådgivning/kompetanseutvikling er både kurs, konferanser, workshops, løpende nettverksdialoger og poenggivende studier. I tillegg finner vi løpende veiledning, rådgivning, samt styremedvirkning.

${ }^{49}$ https://www.nav.no/no/NAV+og+samfunn/Samarbeid/Tilskudd+gjennom+NAV/Tilskudd+til+frivillig+ar beid+mot+fattigdom/Tilskudd+til+sosialt+entreprenorskap

${ }^{50} \mathrm{http} / / /$ www.ferd.no/sosiale_entreprenorer/investeringskriterier 
Vi finner også det som betegnes som skreddersydde kurs på ulike nivåer, der etablererkurs er ett eksempel på et slikt skreddersømtilbud.

Et eksempel på en aktør som tilbyr rådgivning og veiledning, er Batteriet, som er drevet av Kirkens Bymisjon og mottar offentlig støtte:51

Batteriet er et ressurssenter for egenorganisering, selvhjelp og påvirkningsarbeid og bidrar til målrettet, stabil og effektiv drift i organisasjoner som kjemper mot fattigdom, bidrar til opprettelse av nye grupper og organisasjoner innen fattigdomsbekjempelse, og kobler personer og ressurser innen dette feltet.

Så finner vi aktører som tilbyr rådgivning direkte rettet mot sosialt entreprenørskap og sosial innovasjon. Det nyetablerte Senter for sosialt entreprenørskap og innovasjon har også ambisjoner om å bli en aktør blant annet innen rådgivning. 52

\section{Inkubatorvirksomhet}

Vårt materiale viser at inkubatorvirksomhet er å legge til rette for kontorplasser, fysiske møteplasser, møteplasser på sosiale medier, og ulike varianter av seminarer og workshops.

Varigheten av inkubatorinnsatsen varierer. Det ser ut til at det har sammenheng med hvilke andre innsatser som tilretteleggeren tilbyr. For eksempel ser vi at der hvor tilretteleggeren tilbyr både finansiering og samtidig tilbyr inkubatorinnsatser, er innsatsens varighet lik den varighet finansieringen har.

Om innsatsen tilbys av tilretteleggere som ikke tilbyr økonomiske midler eller studiepoeng, finner vi at innsatsen både gis ad-hoc og at den kan være uavgrenset $\mathrm{i}$ tid, det vil si at det er behovet som styrer.

Et eksempel på en respondent som beskriver sin innsats som inkubatorvirksomhet er SoCentral, som sier følgende om sin innsats: ${ }^{53}$

Skal vi løse viktige samfunnsutfordringer må vi bli dyktigere til å skape nye løsninger i samarbeid på tvers av sektorer, fagfelt og bransjer. SoCentral setter i stand slike samarbeid og tar også en aktiv rolle i å utvikle nye løsninger. Ett eksempel på nye løsninger er Aktivitet og Utstyr, hvor vi i samarbeid med en offentlig intraprenør identifiserte et behov, designet et konsept og etablerte en forening som nå videreutvikles i tett samarbeid med både friviilige, offentlige og private aktører. Vi driver også Norges første samfunnsinkubator

\footnotetext{
51 http://www.bymisjon.no/Virksomheter/Batteriet/Informasjon/

$52 \mathrm{http}: / /$ www.sosialinnovasjon.com/

53 http://socentral.no/
} 
der vi skaper et vekstmiljø for nye løsninger på kjente samfunnsutfordringer.

Vårt mål er å inspirere flere til å samarbeid og innovere på tvers.

Et annet eksempel er Social Innovation Camp Norway, der følgende fremgår av kartleggingen:

Hjelpe seks potensielle sosiale innovatører i 3 måneder med å jobbe med virksomhetsmodellen. Metoden kommer opprinnelig fra England. ${ }^{54}$ Resultater er oppstart av nye sosiale innovasjonsvirksomheter/sosial entreprenører, og individuell utvikling av de sosiale innovatørene. Bakgrunnen for innsatsen er at det er vanskelig å starte bedrift, og enda vanskeligere å starte en sosial entreprenøriell virksomhet. Fokus på strategisk arbeid, men også mye fokus på det praktiske (hvordan er hverdagen, hva må du gjøre). ${ }^{55}$

\section{Nettverksbygging}

Nettverksbygging kan være å etablere faste strukturer rundt definerte nettverk, ad-hoc nettverk og fleksible nettverk. Det kan være både fysiske og interaktive møteplasser. Det er også flere som viser til bruk av workshops, seminarer og grupper.

Det er et stort spenn i hvordan denne innsatsen tilrettelegges, fra faste nettverksmøter for eksempel ukentlig eller månedlig, til mer ad-hoc initierte sammenkomster basert på konkrete, løpende behov.

\section{FoU - Forsknings- og utviklingsarbeid}

Det er også stor variasjon hva gjelder FoU som innsats. I vårt materiale finner vi både ulike former for kurs, seminarer, workshops, gruppesamlinger og konferanser. Det er både fysiske og virtuelle tilbud. I materialet finner vi at både private og offentlige aktører viser til at de arbeider med FoU, men det er noe problematisk å identifisere et mønster eller tydelige eksempler på dette, med unntak av noen få høgskoler og en privat aktør.

\section{Utdanning}

Vi finner i vårt materiale enkelte eksempler på utdanning både i offentlig og privat regi. Materialet etterlater imidlertid et inntrykk av at utdanning ikke er særlig utbredt så langt. Et eksempel på et tilbud om utdanning er det tidligere nevnte Jan Sandal Institute. Et annet eksempel er studieprogrammet Sosialt entreprenørskap ved Universitetet i Oslo, som tilbyr 30 studiepoeng på masternivå:

\footnotetext{
54 http://en.wikipedia.org/wiki/Social_Innovation_Camp

55 http://sicamp.no
} 


\begin{abstract}
Målet med studieprogrammet Sosialt entreprenørskap er å gi studenter inspirasjon, kunnskap, verktøy, erfaring og nettverk som øker sannsynligheten for at de vil velge å jobbe med viktige samfunnsmessige utfordringer i det videre arbeidet, og benytte metoder og verktøy fra entreprenørskap og innovasjon i dette arbeidet. På den måten håper vi positive endringer kan skje raskere og smartere. Med universitetet som utgangspunkt er det overordnede læringsutbyttet:
\end{abstract}

Kunnskap om teorier innen et tverrfaglig, nyere forskningsfelt (SE) i sterk vekst.

Innsikt i nye muligheter for bruk av egen kompetanse.

Erfaring med å planlegge og realisere løsninger på samfunnsmessige problemer ved bruk av metoder og verktøy fra tradisjonelt entreprenørskap. ${ }^{56}$

\title{
Juridisk rammeverk
}

Det er få respondenter som rapporterer at de arbeider med juridisk rammeverk. Dette er jo også noe som først og fremst hører til offentlig aktører som departementer og direktoraters ansvarsområde. Imidlertid er det flere respondenter som opplyser at de tilbyr rådgivning og veiledning knyttet til juridisk rammeverk, for eksempel knyttet til virksomhetsstyring, herunder blant annet skattelovgivning.

\section{Strategier og planer/strategisk utviklingsarbeid, ivaretakelse av foretaks/bedrifter interesser, synliggjøring og lobbing}

De fleste av respondentene har krysset av for innsatsene strategisk utviklingsarbeid og synliggjøring. Det er imidlertid noe problematisk å identifisere hva disse innsatsene konkret består i. Det kan se ut til at nettverk og rådgivning, er former for aktiviteter som skal bidra til strategisk planarbeid. Disse aktivitetene er samtidig innsatser som tilretteleggerne tilbyr.

Noen få respondenter gir støtte til bedrifter. Ett eksempel er Ferd Sosiale Entreprenører, som vi tidligere har omtalt, som blant viser til at de i bedrifter/virksomhetene der de går inn med finansiering, også har styrerepresentasjon.

${ }^{56}$ http://www.mn.uio.no/sfe/studier/sosialt-entreprenorskap.html 


\subsection{I hvilken grad fokuserer innsatsene på de fire kjennetegnene ved sosialt entreprenørskap}

I lys av arbeidsgruppens forståelse av hva som er viktige kjennetegn ved sosialt entreprenørskap, stilte vi spørsmål om i hvilken grad innsatsene fokuserer på å utvikle og prøve ut nye løsninger, løsninger som involverer målgruppen i det sosiale entreprenøriske arbeidet, løsninger som stimulerer til samarbeid på tvers av fagfelt og virksomhetsmodeller, og løsninger hvor bærekraft (økonomisk og samfunnsøkonomisk) vektlegges.

\section{Utvikling og utprøving av nye løsninger}

Følgende oversikt viser hvordan respondentene selv beskriver i hvilken grad de er opptatt av å utvikle og prøve ut nye løsninger.

Figur 9.5. Utvikle og prøve ut nye løsninger

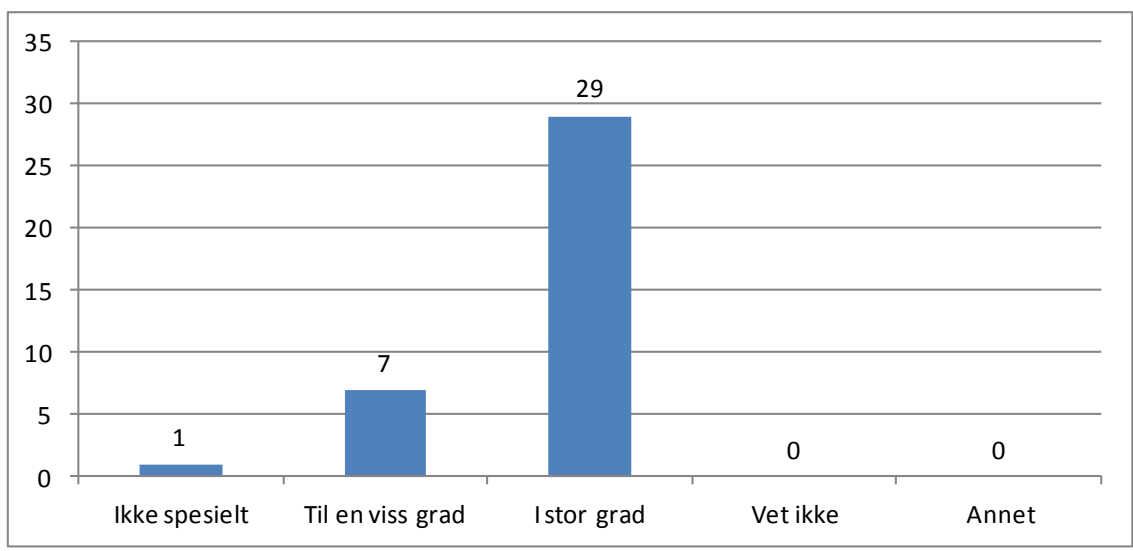

Hovedvekten av respondentene rapporterer at de "i stor grad" er fokusert på å utvikle og prøve ut nye løsninger. De fleste viser til at sosiale utfordringer samfunnet står overfor i vår tid, ikke alene kan løses av offentlige myndigheter. 


\section{Målgruppeinvolvering}

I kartleggingen var vi også opptatt av å måle i hvilken grad respondentene involverer målgruppen.

Figur 9.6. Utvikle og prøve ut nye løsninger som involverer målgruppen for det sosialentreprenøriske arbeidet

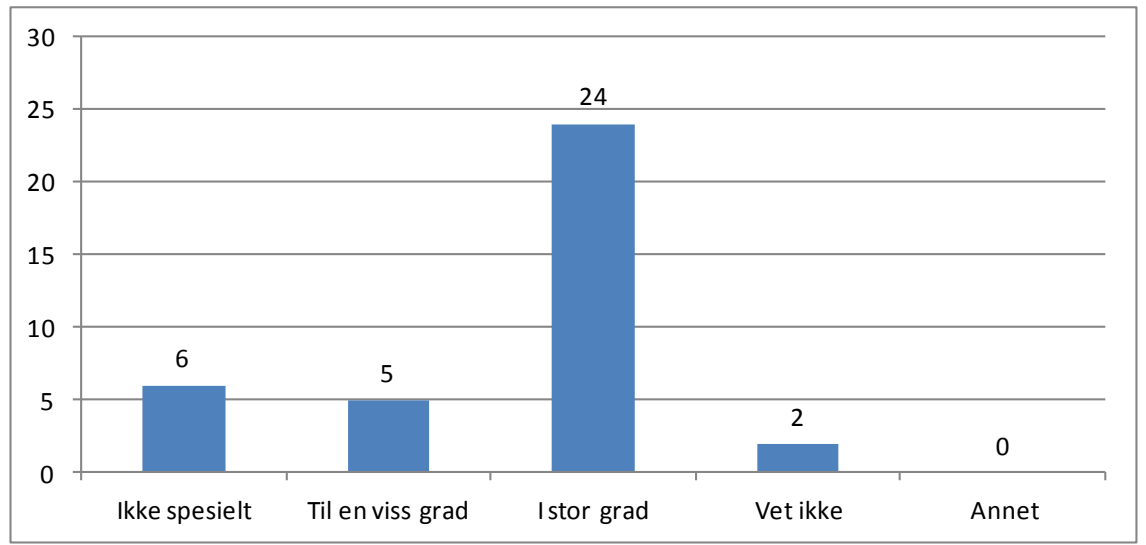

Vi ser at de fleste rapporterer at de "i stor grad" involverer målgruppen. I beskrivelsene av dette vises det blant annet til at modeller utvikles og videreutvikles gjennom tilbakemeldinger fra brukere, gjennomgang av hva som gir best resultater i samarbeid med finansiører, samt egenevaluering.

Formuleringen vi benyttet, "målgruppen for det sosial entreprenøriske arbeidet", kan altså ha blitt oppfattet ulikt. Hvorvidt respondentene oppfatter dette å være sluttbrukeren og/eller den som utfører det sosial entreprenøriske arbeidet, kan derfor ha påvirket svarene.

\section{Samarbeid på tvers av fagfelt og virksomhetsmodeller}

Sosialt entreprenørskap og sosial innovasjon, omtales også som fenomener som er genuint opptatt av å utvikle det som betegnes som "nye samarbeidsformer på tvers av etablerte strukturer", se kapittel 3. Vi var derfor opptatt av å identifisere nærmere hvordan respondentene selv plasserer seg i forhold til dette. 
Figur 9.7. Stimulere til samarbeid på tvers av virksomhetsmodeller

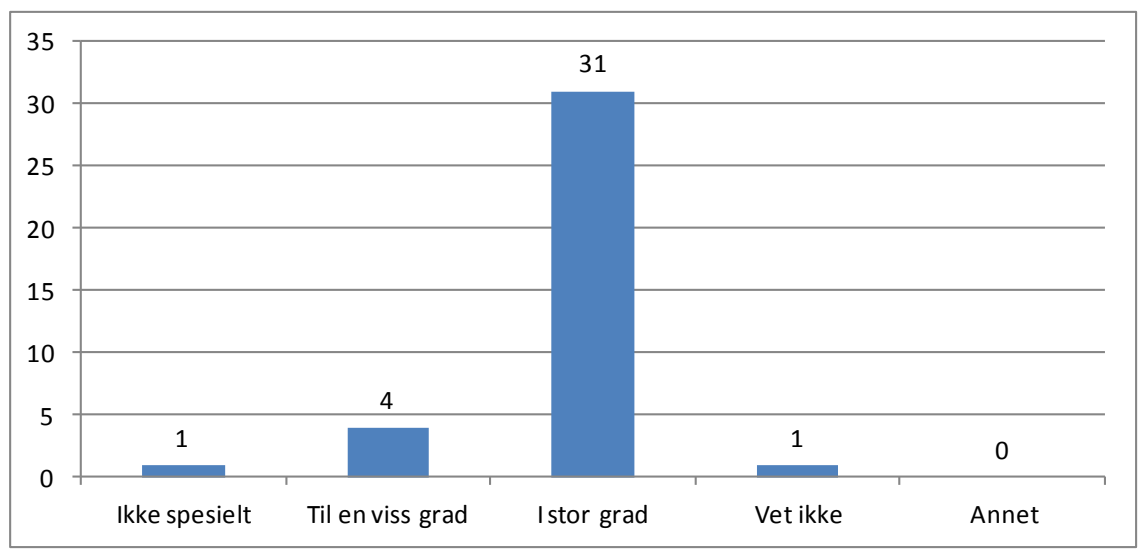

Vi ser her at hovedvekten av respondentene rapporterer at de "i stor grad" stimulerer til samarbeid på tvers. Et gjennomgående trekk i materialet, er at tilretteleggerne anser at sosialt entreprenørskap kjennetegnes blant annet av samarbeid på tvers.

\section{Bærekraft (både økonomisk og samfunnsøkonomisk)}

Vi stilte spørsmål om både økonomisk og samfunnsøkonmisk bærekraft. Følgende oversikt viser hvordan respondentene selv beskriver bærekraften.

Figur 9.8. Utvikle bærekraft, både økonomisk og samfunnsøkonomisk

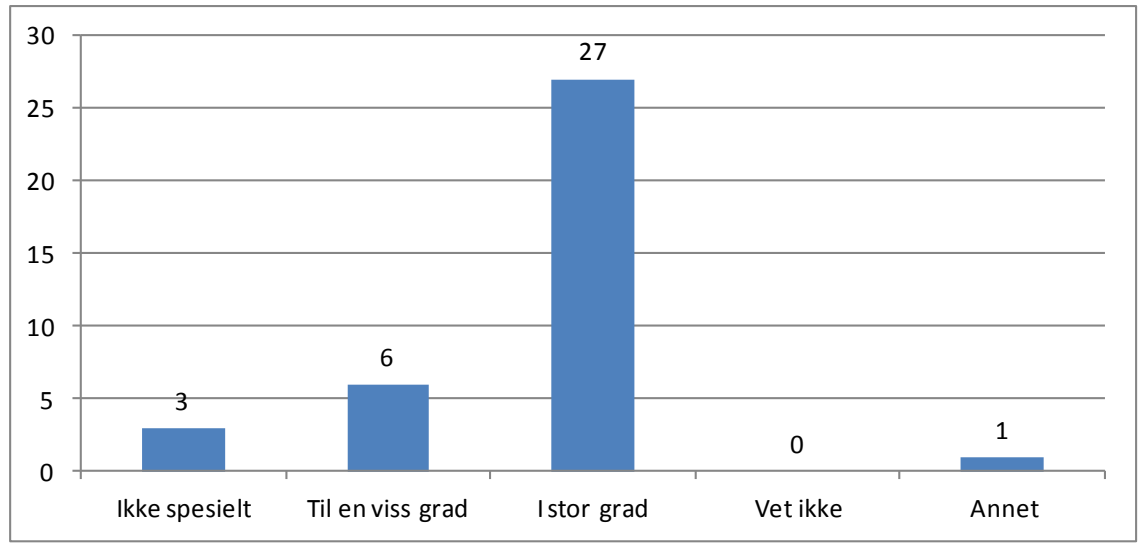

Ser vi nærmere på hvordan respondentene selv beskriver sitt arbeid knyttet til bærekraft, finner vi at de både er opptatt av samfunnsøkonomisk bærekraft og bærekraft for virksomhetene de er tilretteleggere for eller selv driver. Vi har ikke etterspurt om respondentene kan skille på dette, men av svarene fremgår at de fleste fokusert på begge deler.

I gruppen som rapporterer at de er "i stor grad" er opptatt av økonomisk og samfunnsøkonomisk bærekraft, finner vi at fokus på bære- 
kraft i innsatsene ligger til grunn i søknadsbehandling og oppfølging av søknader. Vi finner også beskrivelser som viser at det er en økt interesse for måling og kommunisering av sosial effekt, og at det er diskusjoner om hvordan prosjekter som er igangsatt med offentlige midler, kan spinne ut og bli bærekraftige virksomheter.

\subsection{Oppsummerende kommentar}

Samlet etterlater materialet et inntrykk av at innsats for å legge til rette for sosialt entreprenørskap og sosial innovasjon, er et relativt nytt område i Norge. Vi har funnet eksempler på innsatser innenfor alle kategorier som det er stilt spørsmål om. Nettverksbygging, rådgivning og kompetanseutvikling, samt finansiering, er innsatstyper som synes å være mest utbredt. Nettverksbygging og rådgivning er især innsatser som mange respondenter tilbyr.

Offentlige myndigheter synes i liten grad å tilby innsatser som skal stimulere til sosialt entreprenørskap og sosial innovasjon. Et unntak er den tidligere omtalte tilskuddsordningen til sosialt entreprenørskap rettet mot bekjempelse av fattigdom og sosial eksklusjon. Det ser ut til at det først og fremst er private aktører, som så langt har tatt tak i området og utviklingen av det. Det må imidlertid her tas forbehold om at vi gjennom de valg som er tatt underveis, ikke har fanget opp hele bredden og variasjonen av innsatsene som finnes. 



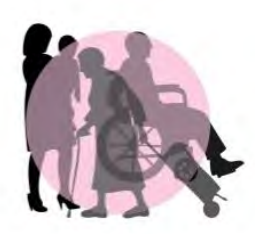

\section{Innsatser for sosialt entreprenørskap og sosial innovasjon i Sverige}

\subsection{Innledning}

I Sverige har interessen for sosialt entreprenørskap, sosial innovasjon og sosiale foretak (socialt företagande) vært økende de siste årene. Vi møter behov for og etterspørsel etter utvikling og kunnskap om dette området fra samtlige samfunnssektorer, og det finnes en økende bevissthet om at det er behov for å finne fram til nye samarbeidskonstellasjoner mellom privat og offentlig sektor og sivilsamfunn for å kunne møte våre samfunnsutfordringer.

Når det gjelder politikken, finnes det en bevissthet om den raske utviklingen. I den nasjonale innovasjonsstrategien som ble lansert i 2012, framheves sosial innovasjon og sosiale foretak (sociala företak) som viktige områder for å møte framtidige samfunnsutfordringer. Innenfor rammen av denne strategien gjennomføres for eksempel satsingen på Mötesplats Social Innovation som et nasjonalt kunnskapssentrum og en nasjonal koordinator for sosial innovasjon og samfunnsentreprenørskap (sämhällsentreprenörskap).

Kommuner og regioner har begynt å etablere sosiale investeringsfond som i første omgang fokuserer på tidlig innsats for barn og unge, men også på etablering av nye arbeidsplasser og tiltak mot bostedsløshet. Private investorer beveger seg langsomt mot såkalt "impact investing", som innebærer at investorene forventer positiv innvirkning på de utfordringene de velger å adressere, samt en rimelig finansiell avkastning.

Da vi på starten av 2000-tallet snakket om sosiale foretak, handlet det i hovedsak om å skape nye jobber og veier til arbeidsmarkedet for grupper som har spesielle vansker med å få eller beholde arbeid. Dette er foretak som i dag omtales som arbeidsintegrerende sosiale foretak (arbetsintegrerande sociala företag), og etablering av slike foretak har pågått siden 1980-tallet, ofte på initiativ fra ideelle organisasjoner eller ansatte i offentlig sektor. I løpet av de siste ca 10 årene har begrepet sosiale foretak blitt utvidet til å omfatte foretak som har til hensikt å løse 
samfunnsutfordringer, utvikle andre deler av velferden og bidra til utvikling i fattige land. Andre begrep brukes også samtidig parallelt, til tider helt og til tider delvis overlappende. Sosialt entreprenørskap og samfunnsentreprenørskap brukes ofte som et mer overgripende begrep for å fange inn hele feltet "foretak med sosiale formål", om enn med noe forskjell når det gjelder utdeling av utbytte, deltakelse med mer. Foretak innenfor den sosiale økonomien (företag inom den sociala ekonomin og socialt företagande) og ideelle foretak (idéburet företagande) er ytteligere to begrep som brukes delvis overlappende med sosiale foretak.

Sosial innovasjon har blitt introdusert i løpet av de senere årene, og er fremdeles ukjent for det store flertall, men virker i hovedsak å bli definert som en ny tjeneste, metode eller produkt som har som formål å svare på samfunnsutfordringer og som kan spres på et marked. Markedet, og til og med forretningsmodellen, kan være privat, offentlig eller ideell/sosial.

Den svenske regjeringen har vedtatt en del tiltak for å stimulere til utvikling på området, for eksempel tok man i 2010 initiativ til en Handlingsplan för arbetsintegrerande sociala företag. ${ }^{57}$ I 2009 ble det avsatt midler til en informasjonskampanje, og Arbetsformedlingen har fått i oppdrag å anskaffe enkelte tjenester fra arbeidsintegrerende sosiale foretak og andre alternative aktører. Innovasjonsstrategien som er nevnt over, er ytterligere et eksempel.

Mange offentlige aktører bidrar på ulike måter til utviklingen, men ingen myndighet har et samlet og tydelig ansvar. De siste 10 årene har Tillväxtverket påtatt seg en samordnende rolle for fremme kunnskapsog erfaringsoverføring, samordning av innsatser med mer, som kan være til støtte for de som ønsker å starte og drive foretak på området. I dette arbeidet deltar Arbetsförmedlingen, Försäkringskassan, Sveriges Kommuner och Landsting, Allmänna Arvsfonden, Svenska ESF-Rådet, Vinnova, Mötesplats Social Innovation og representanter for rådgivere/inkubatorer og foretakenes organisasjoner. Innenfor dette samarbeidet drives websiden Sofisam.

Det finnes ingen egen juridisk form (eget regelverk for organisering) for sosiale foretak/samfunnsentreprenører, svært lite målrettet finansiering og ingen spesielle vilkår ved offentlig anskaffelse av tjenester på området. I forbindelse med implementeringen av EUs nye direktiv for offentlige anskaffelser diskuteres det hvordan det i større omfang kan

${ }^{57}$ http://www.regeringen.se/sb/d/13048/a/144655 
benyttes sosiale kriterier ved anskaffelser og former for innføring av reservert kontrakt.

Et problem som Sverige deler med mange andre land, er manglende oppfølging og statistikk for utvikling på området. Vi vet alt for lite om hva foretakene gjør, hvordan de utvikler seg, hvor mye arbeid de skaper og i hvilken grad de bidrar til bærekraftig vekst. I løpet av 2014 har Tillväxtverket sammen med Statistiska Centralbyrån (SCB) och Handelshögskolan i Stockholm tatt initiativ til å utvikle en modell for over tid å kunne følge utviklingen av sosiale foretak i vid forstand (sosiale entreprenører, arbeidsintegrerende sosiale foretak, samfunnsentreprenører, ideelle foretak osv) som er registrerte med økonomisk virksomhet og som arbeidsgivere.

Det er behov for en kartlegging for å kunne gi et rettferdig bilde av forskning koblet til sosiale foretak og arbeidsintegrering.

Støtte til oppstart og utvikling av sosiale foretak er, enn så lenge, på mange steder i landet koblet til rådgivningsorganisasjonen Coompanion, som fokuserer på kooperativ, sosial og annen virksomhet innen den sosiale økonomien. I den senere tid har det imidlertid vært en utvikling av rådgivning, inkubatorvirksomhet, nettverk med mer, koblet til høyskolers inkubatorer/Science Parks og til organisasjoner i sivilsamfunnet. Disse har et bredere oppdrag innen sosialt entreprenørskap, samfunnsentreprenørskap og sosial innovasjon.

Det utvikles også foretaksforeninger og interesseorganisasjoner som både skal ivareta foretakenes interesser, drive utvikling og gi støtte til foretakene. I fellesskap med rådgivere, etiske banker med flere, tar man også initiativ til å utvikle nye løsninger for finansiering, for eksempel regionale mikrofond, bygdebanker og crowdfundingsløsninger. Etterspørselen etter utviklingsmidler er stor. Dette har vist seg når Tillväxtverket fra 2012 har utlyst til sammen 13 millioner kroner til utviklingsarbeid innen samfunnsentreprenørskap og sosial innovasjon. Det har resultert i ca 550 søknader om til sammen drøyt 200 millioner. 89 prosjekt har fått bevilget midler (ca 25 millioner). De fleste søker om midler til å motvirke arbeidsløshet gjennom foretak eller nye metoder. Blant andre områder det søkes om midler til, er finansieringsløsninger, inkubatorer med mer, samt utvikling innenfor pleie og omsorg og grønne næringer og foretak. 


\subsection{Respondentene}

I den svenske delen av kartleggingen ble det sendt ut spørreskjema til 47 aktører som driver med virksomhet rettet mot å fremme sosialt entreprenørskap og sosial innovasjon. I noen tilfeller har mottakeren spredd spørreskjemaet videre til medlemsorganisasjoner eller innenfor sitt styre. Det innebærer at spørreskjemaet har nådd flere enn 47 aktører. Av de som opprinnelig ble invitert til å delta, er det ni som ikke har svart.

De kartlagte aktørene virksomhetene har i hovedsak oppgitt at de befinner seg enten i tredje sektor (21) eller offentlig sektor (14). Sju av de kartlagte aktørene har oppgitt at de befinner seg i privat sektor.

Aktørenes fordeling på sektor fremgår av figuren nedenfor.

\section{Figur 10.1. Sektor}

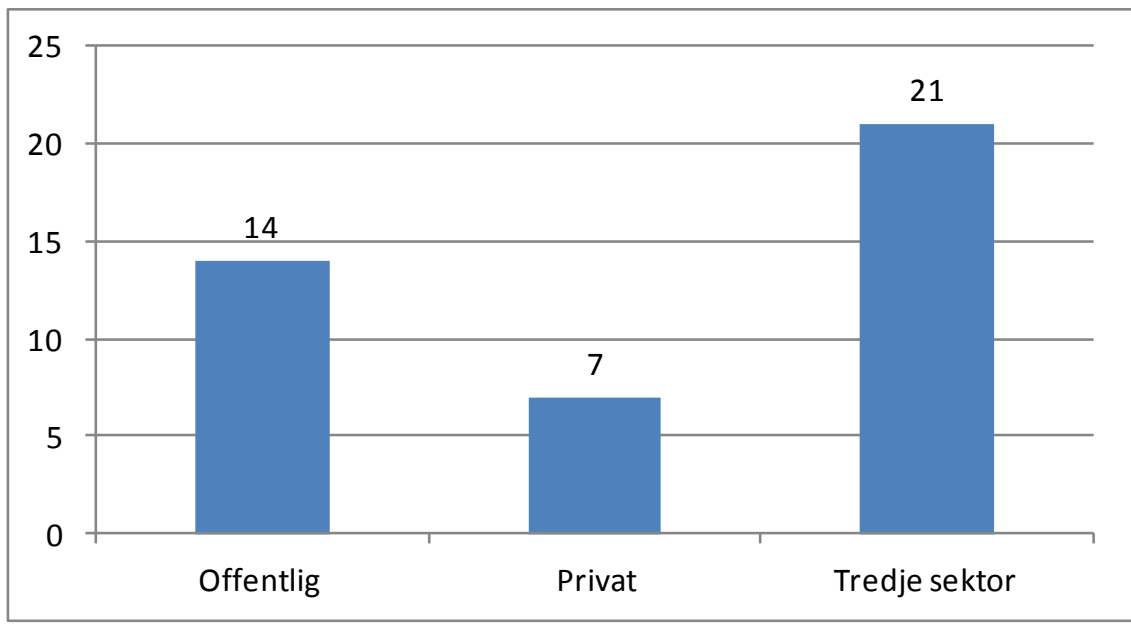

Blant de offentlige aktørene finner vi flere statlige myndigheter som formidler midler (enten egne eller EUs) til prosjekter, men også Arbetsförmedlingen og kommuner som samarbeider med sosiale entreprenører for å skape jobber.

Bland dem som har oppgitt at de befinner seg i privat sektor finnes det to foretak som er både sosiale entreprenører og arbeider med å utvikle flere slike foretak, samt Ekobanken (medlemsbank) og Reach for Change (Kinneviks initiativ). Konsulentorganisasjonen Serus, som er en økonomisk forening som har oppdrag og oppdragsgivere i hovedsak i tredje sektor, oppgir at de tilhører både privat og tredje sektor.

Respondentene i tredje sektor domineres av organisasjoner som arbeider med rådgivning, utdanning, inkubatorer med mer, men her finner vi også foretak (kvinners, kooperativer mfl), som også arbeider med 
sosialt entreprenørskap, organisasjoner som spesifikt arbeider med utvikling av sosialt entreprenørskap i en videre forstand, folkebevegelser og interesseorganisasjoner. JAK, som også er en medlemsbank, har definert seg som tredje sektor.

\subsection{Hvilke hovedtyper innsatser er kartlagt}

På dette spørsmålet har respondentene hatt mulighet til å oppgi flere svaralternativer for å beskrive innsatsenes innretning.

Figur 10.2. Innsatser

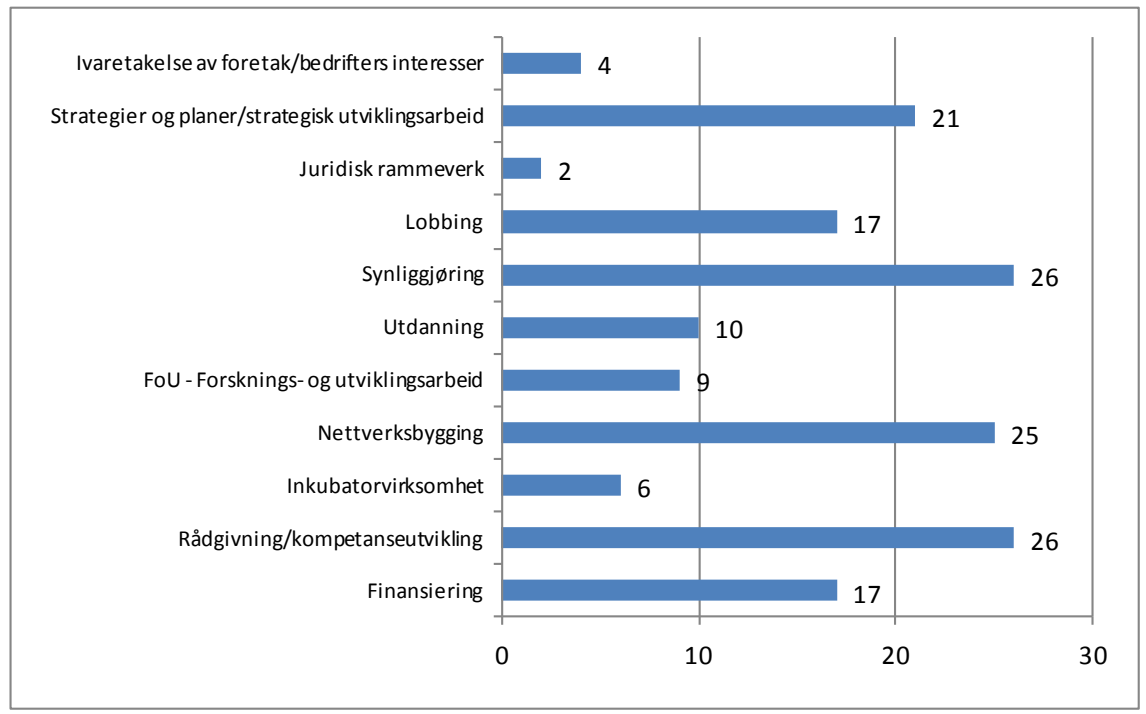

Fra svarene fremgår det at de fleste har innsatser innen flere kategorier. Synliggjøring er sammen med rådgivning og kompetanseutvikling, nettverksbygging og strategisk utviklingsarbeid de hyppigst forekommende innsatsene. Bare et fåtall er aktive innen juridisk rammeverk, ivaretakelse av interesser og inkubatorvirksomhet. Inkubatorvirksomhet drives av noen høyskoler i tilknytning til ordinære inkubatorer eller Science Parks, men også av private og ideelle aktører.

Et eksempel på en respondent som kombinerer mange ulike innsatser er Centrum för socialt entreprenörskap i Sverige (CSES). På sin hjemmeside skriver de:

CSES stimulerar och stödjer utvecklingen av sociala innovationer, för att bidra till framväxten av nya företag och organisationer som löser angelägna sociala problem. Vi tror att den personliga drivkraften är viktigare än innovat- 
ionshöjden för att lyckas. Därför satsar centret på att även hjälpa till i de mycket tidiga idéfaserna genom personlig rådgivning. För sociala entreprenörer som kommit längre och vill ha stöd att snabbare och säkrare nå ut på marknaden finns CSES inkubator. Dessutom arrangerar vi olika inspirationsoch kunskapsseminarier inom socialt entreprenörskap. ${ }^{58}$

Innen finansiering finnes det fremfor alt flere statlige myndigheter som formidler prosjektmidler blant annet til støtte for sosialt entreprenørskap, men også to banker, ett mikrofond og noen organisasjoner som gir støtte ved å finne finansiering (Impact Invest, inkubatorer). Også på dette området kombineres flere innsatser og samvirke for å tilby best mulig støtte til foretakene. For eksempel tilbyr Mikrofonden väst, i samhandling med andre aktører, både rådgivning og nettverk til dem som søker finansiering via fondet. 59

Nettverksaktiviteter handler oftest om å skape arenaer for møter, utveksling av erfaringer, men også forretningsutvikling for de sosiale entreprenørene som respondenten støtter på ulike måter.

Synliggjøring handler om å vise fram forbilder og samfunnsnytte av sosialt entreprenørskap, men også om å vise fram de spesielle forutsetningene og behovene de sosiale entreprenørene har. Strategier og planer etc handler om å forsøke å påvirke beslutningstakere med mer, men også om å utvikle egen virksomhet og samarbeid slik at man kan tilby bred og langsiktig støtte til entreprenørene, slik at deres mulighet for å overleve og bli bærekraftige blir styrket.

\subsection{I hvilken grad er dette nye innsatser}

Blant innsatsene som inngår i kartleggingen, er det stor spredning når det gjelder alder. Om lag $40 \%$ av innsatsene ble startet etter 2009, og en like stor andel i perioden 2000-2009. En liten andel (6\%) ble startet allerede før 1999.

Innsatser for sosialt entreprenørskap og sosial innovasjon har ofte vokst fram som en del av en naturlig utvikling av organisasjoner som har vært rettet mot å støtte etablering av foretak, kooperasjon, sosial virksomhet, arbeid/sysselsetting etc. Det er derfor i noen tilfeller usikkert om svarene på dette spørsmålet gjenspeiler året den aktuelle organisa-

\footnotetext{
58 www.cses.se

${ }^{59} \mathrm{http}: / /$ mikrofondenvast.se/vara-tjanster/
} 
sjonen eller innsatsen startet. Blant dem som oppgir at de har drevet virksomhet på området lengst, finner vi først og fremst organisasjoner i tredje sektor. I de senere årene har det imidlertid blitt etabert noen inkubatorer og organisasjoner som har sosialt entreprenørskap og/eller sosial innovasjon som sitt viktigste eller eneste mål. Blant disse finner vi de fleste innsatsene i privat regi, og de har i de fleste tilfellene, så nær som ett, startet etter 2009.

Om lag $10 \%$ av respondentene, de fleste fra offentlig sektor, har ikke svart på spørsmålet.

\subsection{Hva er formål og målgruppe for innsatsene}

Blant respondentene finnes dem som har tydelige og avgrensede mål og målgrupper. For eksempel støtter Myndigheten för Ungdoms- och Civilsamhällesfrågor bare prosjekter som retter seg mot unge, og Föreningen Unga sociala entreprenörer som har som mål at det skal bli flere (og sterkere) unge sosiale entreprenører. Organisasjonen Winnet har kvinners entreprenørskap i fokus og arbeider blant annet med å styrke kvinners rolle i den regionale utviklingen, og ser sosialt entreprenørskap som en måte å styrke en bærekraftig regional utvikling på. Akkurat dette er et overordnet mål også for flere av myndighetene: Sosialt entreprenørskap og sosiale foretak bidrar til en bærekraftig samfunnsutvikling, flere i jobb og økt deltakelse for innbyggerne. Derfor har man virksomheter som har som mål å styrke utviklingen gjennom å fordele prosjektmidler, bygge nettverk, skape og spre kunnskap med mer, koblet til myndighetenes overordnede oppdrag eller regionale ansvarsområde.

Flertallet av respondentene har målgrupper og mål innenfor flere områder. Ofte handler det da om informasjon, rådgivning, utdanning og inkubatorvirksomhet rettet mot blivende og/eller etablerte sosiale entreprenører, sosiale foretak, sosial økonomi mfl. Under følger en gjennomgang med eksempler ut fra fire hovedkategorier av mål.

\section{Innsatser med formål å støtte sosialt entreprenørskap og sosial innovasjon $\mathrm{i}$ arbeidet med å inkludere utsatte grupper $\mathrm{i}$ arbeid og samfunnsliv}

Aktørene på dette feltet finnes i hovedsak i tredje sektor og den sosiale økonomien, men også Arbetsförmedlingen har innsatser som bidrar. Blant de kartlagte innsatsene finnes utdanning av veiledere, forelesninger, produksjon og spredning av informasjons- og utdanningsmateriale, nettverk, utdanning av arbeidsledige, kompetanseutvikling av entreprenørene, rådgivning, langsiktig støtte med mer. IOGT-NTO har avsatt mid- 
ler til risikokapital, Tillväxtlån, til medlemsforeninger som starter sosiale foretak for å skape arbeid i hovedsak for tidligere rusmisbrukere.

\section{Innsatser for å støtte sosialt entreprenørskap og sosial innovasjon generelt}

Det er i denne kategorien vi finner flest aktører. De representerer offentlig sektor (statlige, regionale, høyskoler med mer), tredje sektor og den sosiale økonomien og private initiativ i ulike former. Blant de kartlagte innsatsene finner vi:

Offentlig sektor: Fordeling av prosjektmidler til innovasjon og entreprenørskap for å utvikle samfunnet og nye innovasjonsprosesser, forsøksvirksomhet, metodeutvikling, prosjekt og inkubatorvirksomhet, støtte til entreprenører for å komme ut på markedet, utvikle/tilpasse innovasjonssystemet, informasjons- og kunnskapsspredning.

Tredje sektor: Støtte gjennom rådgivning, finansiell veiledning, nettverk og mentorskap, eksperthjelp, akseleratorprogram, innovasjonslaboratorium, rundebordsmøter og møteplasser/inspirasjonstreff, finansieringsløsninger gjennom garantier og lån, kompetanseutvikling av lærere, støtte til "changemakers".

Private initiativ: Støtte til "change leaders", hovedsaklig innenfor området barn og unges situasjon, med lønn, kunnskap og nettverk, arbeid for å øke investeringene og tilgangen på kapital gjennom nettverk og møteplasser mellom investorer og foretak, samt gjennom støtte til foretakene i investeringsprosessen, lån til foretak og prosjekter som skaper økologisk, sosial eller kulturell merverdi, implementering av metoder for å måle sosial nytte.

\section{Innsatser for å inkludere utsatte grupper i arbeid og samfunnsliv generelt}

Aktørene her finnes innenfor offentlig sektor, og utover Arbetsförmedlingens generelle innsatser finnes også innsatser rettet mot unge og personer med nedsatt funksjonevne. I begge tilfeller kanaliseres støtten som prosjektmidler til organisasjoner i tredje sektor. Prosjektstøtten krever høy grad av involvering av målgruppene og kan brukes for å skape arbeid, foretak og ulike utdanningsaktiviteter.

\section{Innsatser med andre mål}

På dette området finner vi de kartlagte aktørene i den tredje sektor og den sosiale økonomien. Det handler om rådgivning, kompetanseutvikling, lobbing, nettverk med mer, som har til hensikt å styrke ulike gruppers (for eksempel kvinners) eller grupper av foretaks (for eksempel verdibaserte) rolle i næringslivet, samfunnet og samfunnsutviklingen. 


\subsection{Hvordan er innsatsene finansiert}

Tretten av respondentene svarer at innsatsen finansieres av offentlige midler. En respondent svarer at innsatsen finansieres av private investorer, en annen at innsatsen finansieres av private fond. Fire svarer at de er kundefinansierte og 22 svarer at de finansieres av "annet". I spørreskjemaet har respondentene bare kunnet velge ett alternativ på dette spørsmålet. De respondentene som har svart "annet" er i stor grad aktører som finansieres av både offentlige og private midler. Dette er da også den finansieringsformen som i størst grad gjelder for aktørene som er med i kartleggingen.

\section{Figur 10.3. Finansieringskilder}

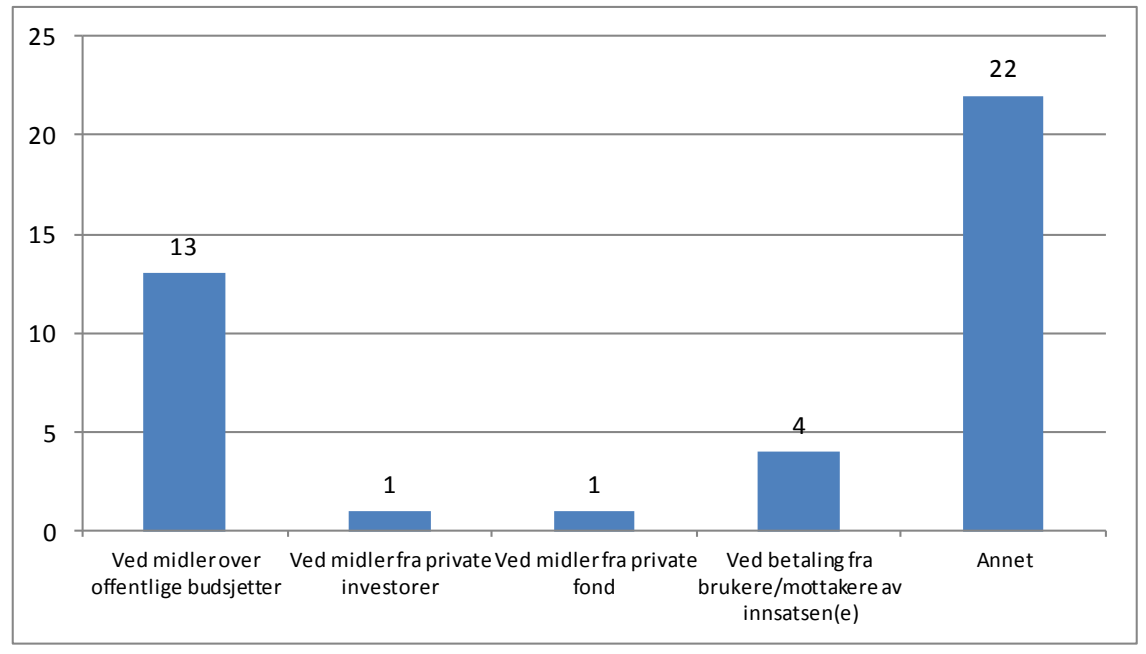

Ettersom 14 offentlige aktører har svart, er det sannsynlig at det er blant dem vi finner de 13 som er finansiert bare ved offentlige midler. Flertallet av aktørene innenfor den sosiale økonomien har en sammensatt finansiering der offentlige midler kan være virksomhetsbidrag, prosjektmidler, men også betalte oppdrag. Mange av dem tar også betalt for utdanning og andre aktiviteter, framfor alt av foretak og organisasjoner, og i liten grad av privatpersoner. De to som får sin finansiering fra private kilder er Inkludera Invest (rådgivning/langsiktig støtte til utvalgte sosiale entreprenører) og Reach for Change (støtte og lønn til et mindre antall utvalgte entreprenører som arbeider for et bedre liv for barn). 


\subsection{Hvordan legger innsatsene til rette}

Her presenteres noen eksempler på innsatser for sosialt entreprenørskap.

\section{Finansiering}

Mikrofonden Väst (det finnes flere) tilbyr garantier og finansiering til foreninger, kooperativ, lokalsamfunn, sosiale foretak, stiftelser, og utviklingsgrupper i Västra Götaland.

Mikrofonden erbjuder bland annat borgen då er organisation behöver banklån för till exempel investeringar mm. På så sätt behöver till exempel inte styrelseledamöter eller medlemmar ta personlig borgen. Vi erbjuder även annat finansiellt stöd, såsom placering i förlagsinsatser, aktieandelar, mikrolån, crowfunding, finna externa kapital $\mathrm{mm}$. Vi samarbetar bland annat med Coompanion, Ekobanken och Almi.60

Et annet eksempel er Impact Invest Scandinavia:

Founded in 2012, is the first impact investor membership network in Scandinavia. Our mission is to promote the growth of social and sustainable enterprises in Scandinavia and around the world by supporting investments in companies that deliver measurable social as well as financial returns. We offer a community of practice to facilitate and support impact investing by matching our member investors with pre-qualified social enterprises, entrepreneurs or funds. Impact Invest Scandinavia's six-month Investment Readiness Programme is designed specifically to support ventures that are in early commercial phase or wish to seek capital to scale-up. The business idea should deliver clear benefits to society and/or environment. ${ }^{61}$

\section{Rådgivning og kompetanseutvikling}

Blant eksempler på rådgivning og kompetanseutvikling, vil vi nevne følgende:

Coompanion breddar entreprenörskapet och ger er som vill förverkliga företagsidéer tillsammans skräddarsydd information, företagsrådgivning och utbildning - från idé till framgångsrikt företagande.

${ }^{60}$ www.mikrofondenvast.se/

61 www.impactinvest.se 
Coompanion finnes på 25 steder i hele landet - stort sett er det et Coompanion i hvert len.62 Coompanion driver prosjekter, gir informasjon og rådgivning innen oppstart og drift av sosiale foretak slik at flere blir delaktive i arbeidslivet. ${ }^{63}$

Inkludera Invest er en ideell forening.

Inkludera investerar i social utveckling. Investeringen består inte av pengar, utan av ett långsiktigt partnerskap med våra entreprenörer. Vi har utformat en modell, "Inkludera-modellen" som vi arbetar efter tillsammans med respektive entreprenör. Inkludera ger entreprenörerna ett professionellt näringslivsperspektiv så att deras verksamheter utvecklas och stärks. ${ }^{64}$

\section{Inkubatorsverksamhet}

\section{Social innovation vid LU Open Innovation Center}

The mission is to create a social innovation hub together with our community that supports individuals and organizations that address social, environmental or cultural needs through new strategies, concepts, ideas and organizations. SoPact is a project funded by Tillväxtverket aimed at testing the startup accelerator model with social ventures. The aim of this is to determine the feasibility of this method in starting and growing social ventures that address a social, cultural or environmental need, and can become financially sustainable social ventures. 65

\section{CSES - Centrum för socialt entreprenörskap Sverige}

Inkubator ger stöd att säkrare och snabbare utveckla socialt entreprenörskap helt kostnadsfritt genom omfattande affärsutvecklingsstöd och en kreativ miljö. Som inkubatorsbolag erbjuds man kostnadsfritt en personlig affärscoach och en fysisk arbetsplats under 4-6 månader. Med coachen sätts en gemensam målbild upp och därefter sker regelbundna möten, där man följer en strukturerad coach- och rådgivningsprocess som är anpassad just för sociala entreprenörer. Perioden i inkubatorn är 4-6 månader och antagning sker löpande. CSES drivs av en ideell förening. 66

\section{Nettverksbygging}

Blant eksempler på nettverksbygging kan nevnes Föreningen SKOOPI og Centrum för pulbikt entreprenörskap.

\footnotetext{
62 www.coompanion.se

63 www.coompanion.se

64 www.inkluderainvest.se

65 www.lusic.se /

${ }^{66}$ www.cses.se
} 
Föreningen SKOOPI är en nationell intresse- och nätverksorganisation som arbetar med stöd och utbildning till arbetsintegrerande sociala företag. SKOOPI arbetar även med opinionsbildning för att påverka förutsättningarna för att starta och driva sociala arbetsintegrerande sociala företag. SKOOPI fungerar som mötesplats för medlemsorganisationerna och anordnar mässor, regionmöten och samverkansträffar. ${ }^{67}$

Centrum för publikt entreprenörskap

är en regional mötesplats och utvecklingsarena för samhällsentreprenörer i Skåne genom att stödja individer och organisationer med samhällsförbättrande idéer och initiativ. Med en metod baserad på folkbildning och i samverkan med andra aktörer bidrar man till lokalt engagemang och lokal infrastruktur genom att utveckla lokala utvecklingsnoder. Detta CPE är en stödfunktion till dessa utvecklingsnoder, genom regionalt kunskaps- och nätverksbyggande, kopplat till internationella nätverk med bred kunskap.68

\section{Forskning og utvikling}

Flere svenske forskere er med i det nordiske forskernettverket Social Entrepreneurship Research Network for the Nordic Countries, SERNOC.69 Det drives forskning på feltet ved flere læresteder i Sverige.

VINNOVA driver program for å styrke innovasjonskraften i Sverige. Programmene har ulik innretning og favner over flere samfunnsområder og næringsgrener. VINNOVAs program har tre hovedretninger: Strategisk viktige områder, innovasjonsevner hos spesifikke målgrupper samt grenseoverskridende samarbeid. VINNOVA har ikke noen spesiell satsing rettet mot sosiale foretak, men kommer til en viss grad til å prioritere dette i flere pågående og kommende satsinger. ${ }^{70}$

\section{Utdanning}

Som eksempel på utdanning kan nevnes Tanke \& Handling som:

är fokuserat på utveckling av sociala arbetskooperativ och andra arbetsintegrerande sociala företag samt lösningar för brukarinflytande.

$T \& H$ foreleser, har utdanninger, skriver bøker, deltar i prosjekter, arbeider med forskningsoppdrag og hjelper til med strategisk planlegging. De driver også en Instruktør-og Virksomhetslederutdanning i sosiale foretak

\footnotetext{
67 www.skoopi.coop

${ }^{68}$ www.publiktentreprenorskap.se

${ }^{69} \mathrm{http}: / /$ sernoc.ruc.dk

70 www.vinnova.se
} 
som er lagt til en folkhögskole. T\&H er arrangører av en lengre utdanning i å starte sosiale foretak rettet mot langtidsarbeidsledige, anskaffet av Arbetsförmedlingen. ${ }^{71}$

Coompanionkontorene over hele landet gjennomfører og deltar i ulike utdanninger innenfor oppstart og ulike stadier av utviklingen av kooperativer og sosiale foretak. ${ }^{72}$

\title{
Synliggjøring og kunnskapsspredning
}

Som eksempel på synliggjøring og kunnskapsspredning kan nevnes Malmö Högskola - Mötesplats Social Innovation.

\begin{abstract}
Mötesplats Social Innovations (MSI) främsta uppgift är att följa vad som händer inom området, både i Sverige och internationellt och se till att kunskap och erfarenheter sprids. MSI initierar också forskning, utvecklingsarbete och nya samarbetskonstellationer. MSI publicerar skrifter för kunskapsspridning och arrangerar, ofta tillsammans med andra partners, större konferenser och kunskapsseminarier med nationell, nordisk och internationell räckvidd. De fyra områden som MSI fokuserar på idag är: Samverkansmodeller, Finansiering och Effektmätning, Affär och Samhällsnytta samt Forskning och Utbildning.

Nyhetsportalen koordinerar, samlar och delar information om social innovation och samhällsentreprenörskap. Här kan den intresserade också följa social innovation i politiken i Sverige och på EU nivå.73
\end{abstract}

Et annet eksempel er Tillväxtverket som driver et program for å fremme samfunnsentreprenørskap og sosial innovasjon. Programmet inneholder flere ulike innsatser. Blant annet skal programmet bidra til å synliggjøre sosial foretaksvirksomhet. Dette skjer blant annet gjennom kontinuerlig samarbeid med berørte myndigheter og organisasjoner, fordeling av prosjektmidler med mer. Tillväxtverket har publisert flere rapporter og skrifter på området. En del av dette består i drift og utvikling av kunnskapsportalen www.sofisam.se i samarbeid med andre myndigheter og foretakenes organisasjoner. ${ }^{74}$

\footnotetext{
71 http://tankeochhandling.coop/

72 www.coompanion.se

73 www.socialinnovation.se

${ }^{74}$ www.tillvaxtverket.se
} 


\section{Lobbing}

Som eksempel på lobbing kan nevnes SERUS.

SERUS är ett utvecklingsinriktat företag som erbjuder tjänster till verksamheter och organisationer som vill utveckla och realisera idéer. SERUS arb etar med att informera, förnya, stärka och utveckla sociala företag. För SERUS är sociala företag, företag som arbetar med samhälleliga ändamål. Det kan handla om allt från energikooperativ till vård- och omsorgsinrättningar eller från byalagsföretag till arbetsintegrerande sociala företag. Genom expertkunskap och nätverk kopplat till social ekonomi, lokal och regional utveckling påverkar SERUS politiken och samhällsstrukturen. ${ }^{75}$

\section{Strategi- og planlegging}

Social innovation vid LU Open Innovation Center har tatt initiativ til og driver et prosjekt/utviklingsarbeid med mål om å drive fram en nasjonal agenda for forskning og utvikling rundt sosialt entreprenørskap. Arbeidet gjennomføres som et bredt samarbeid og skal være klart på senhøsten $2014 .{ }^{76}$

Region Skåne har medvirket til og skrevet under en avtale om samarbeid med den verdibaserte sektoren i Skåne. Denne inneholder blant annet formuleringer om sosiale foretak og entreprenørskap. Regionen tar også andre initiativ og driver strategisk utviklingsarbeid på området innen rammen for sitt arbeid med regionalutvikling og entreprenørskap.

\section{Juridisk rammeverk og forvaltning}

Dette er i all hovedsak myndighetenes ansvarsområde. Som det har framgått til nå, finnes det ingen egen lovgivning og svært fă spesielt tilpassede regler. Det skjer imidlertid en utvikling der myndigheter og kommuner går gjennom sin informasjon og tilpasning av regler slik at disse skal inkludere sosiale entreprenører og sosiale foretak på en bedre måte.

75 www.serus.se

76 www.lusic.se 


\subsection{I hvilken grad fokuserer innsatsene på de fire kjennetegnene ved sosialt entreprenørskap}

Svarene viser generelt en god overensstemmelse mellom de svenske innsatsene og fire kjennetegene som arbeidsgruppen har vektlagt ved sosialt entreprenørskap: "Utvikle og prøve ut nye løsninger", "utvikle og prøve ut nye løsninger som involvere målgruppen for/medarbeidere i det sosialentreprenøriske arbeidet", "stimulere til samarbeid mellom fagfelt og virksomhetmodeller", samt "å stimulere til bærekraft - økonomisk og samfunnsmessig".

De aller fleste svarer at de "til en viss grad" eller "i stor grad" gjør dette og godt over halvparten i "stor grad" på alle spørsmål.

Blant våre respondenter svarer noen færre det samme for utvikling og utprøving av nye løsninger, og om lag halvparten svarer at de "i stor grad" har fokus på henholdsvis involvering av målgruppen og økonomisk bærekraft.

Respondentene synes å legge et særskilt stort fokus på utvikling av sosialt og økonomisk bærekraftige virksomheter, nær 8 av 10 svarer at de i stor grad fokuserer på dette.

Det er vanskelig å se klare forskjeller mellom svarene fra ulike grupper av aktører. Et spørsmål der det likevel er en viss forskjell er det som handler om å involvere målgruppen. I hovedsak har private og nyere innsatser mindre fokus på å involvere målgruppen. I noen tilfeller kan man ane at den som har svart har vurdert ut fra egen virksomhets utforming og gjennomføring, og ikke ut fra hva man etterstrever som mål med de innsatsene man gjennomfører.

\section{Utvikle og prøve ut nye løsninger}

Figur 10.4. Utvikle og prøve ut nye løsninger

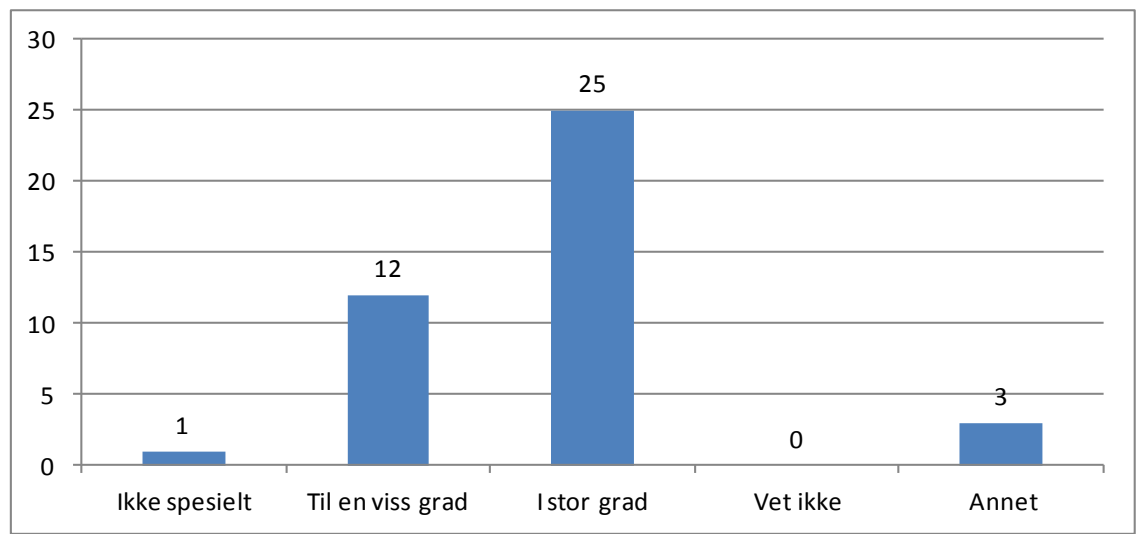


Et eksempel er SE-Forums akseleratorprogram og innovasjonslab som nettopp forsøker å prøve ut nye løsninger på de samfunnsproblemene som deltakerne har med seg. Andre eksempler er ekstra lang utdanningstid i de av Arbetsförmedlingens utdanninger som er rettet mot å starte sosiale foretak, og støtte til start og utvikling gjennom sosial franchising av forretningsideer som er sosialt og økonomisk bærekraftige.

\section{Målgruppeinvoldering}

Blant de som svarte, som arbeider direkte med å skape eller støtte sosiale foretak, svarte en overveiende majoritet "i stor grad". Deltakelse fra målgruppen løftes frem som en nøkkelfaktor, det å utvikle forståelsen for målgruppens behov. Målgruppen er ofte initiativtakere og drivende.

Figur 10.5. Utvikle og prøve ut nye løsninger som involverer målgruppen for det sosialentreprenøriske arbeidet

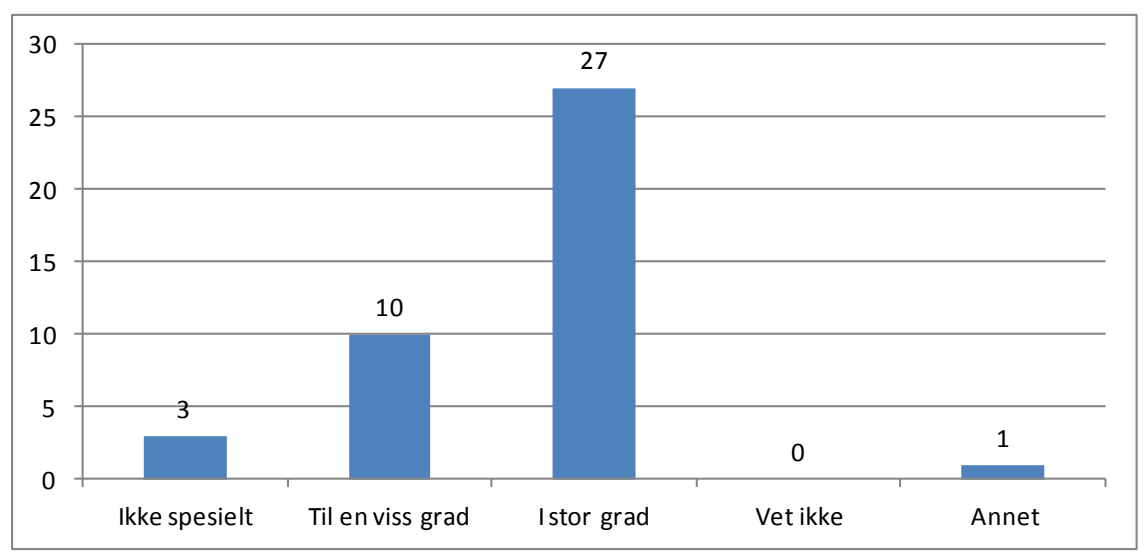

Eksempler er forsøksaktiviteter for å prøve ulike løsninger/sosiale innovasjoner, og utvikle former for forretningsutvikling for foretakene gjennom rådgivning, utdanning, nettverksbygging med mer. Men også nye veier for å skape sikkerhet for lån, og implementering av metoder for å vise den samfunnsmessige nytten ved virksomhetene, for eksmpel gjennom Social Return on Investment (SROI).

\section{Samarbeid på tvers av fagfelt og virksomhetmodeller}

Målet for samarbeidet varierer i forhold til aktørenes oppdrag. Flere arbeider med å utvikle samarbeid mellom sosiale foretak, mellom sosiale foretak, samfunnet og det private næringslivet. Dette for å styrke de sosiale foretakenes rolle i samfunnet og mulighetene for agere på et marked. Samarbeid er ofte en forutsetning for virksomheten, ikke minst når det gjelder finansiering. Myndigheter stiller i blant krav til samarbeid for å få finansiering. 
Figur 10.6. Stimulere samarbeid på tvers av virksomhetsmodeller

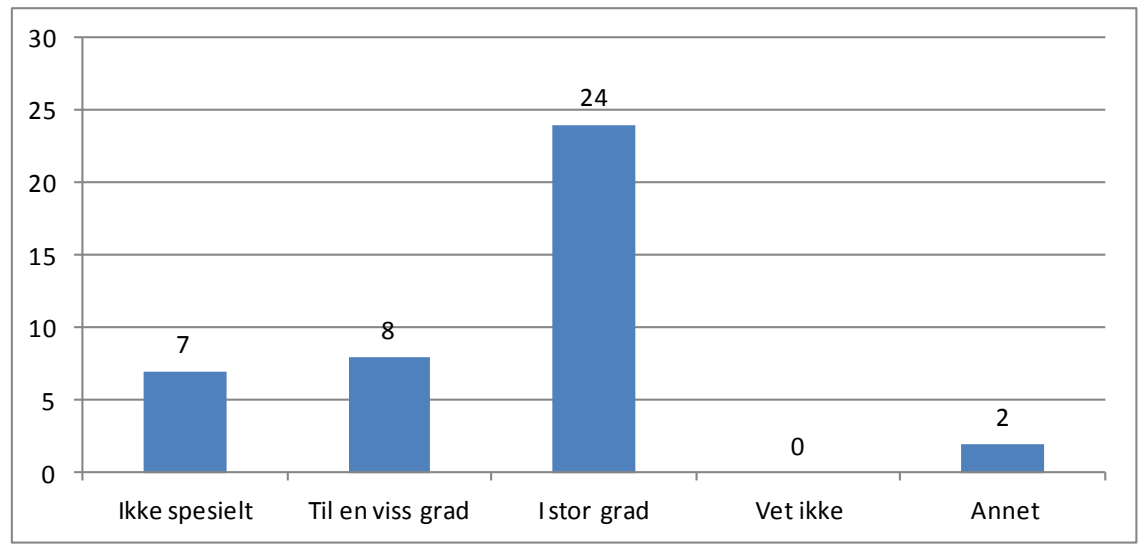

Andre har fokus på å styrke bedriftssamarbeid for å styrke foretakenes $ø$ konomiske bærekraft og langsiktige holdbarhet.

Samarbeid mellom de ulike sektorene fremmer bærekraft og holistisk problemløsning. På flere hold arbeider man med å integrere en sosial dimensjon i Triple Helix $=$ Quadrupel Helix .

De som svarer "ikke spesielt" har en tydelig avgrenset virksomhet eller målgruppe som for eksempel å skape investornettverk og arbeid i og med skoler.

\section{Utvikle bærekraft (økonomisk og samfunnsøkonomisk)}

I stort sett samtlige svar vektlegges betydningen av bærekraft i begge betydninger av begrepet; At den økonomiske og samfunnsøkonomiske utviklingen styrkes av et samarbeid og integrasjon av entreprenørskap i samfunnets innsatser. Flere påpeker at det er nettopp dette som er årsaken til sosialt- og samfunnsentreprenørskap - at begge (alle) aspektene er med: Sosial, økonomisk og økologisk bærekraft. 
Figur 10.7. Utvikle bærekraft, både økonomisk og sosialøkonomisk

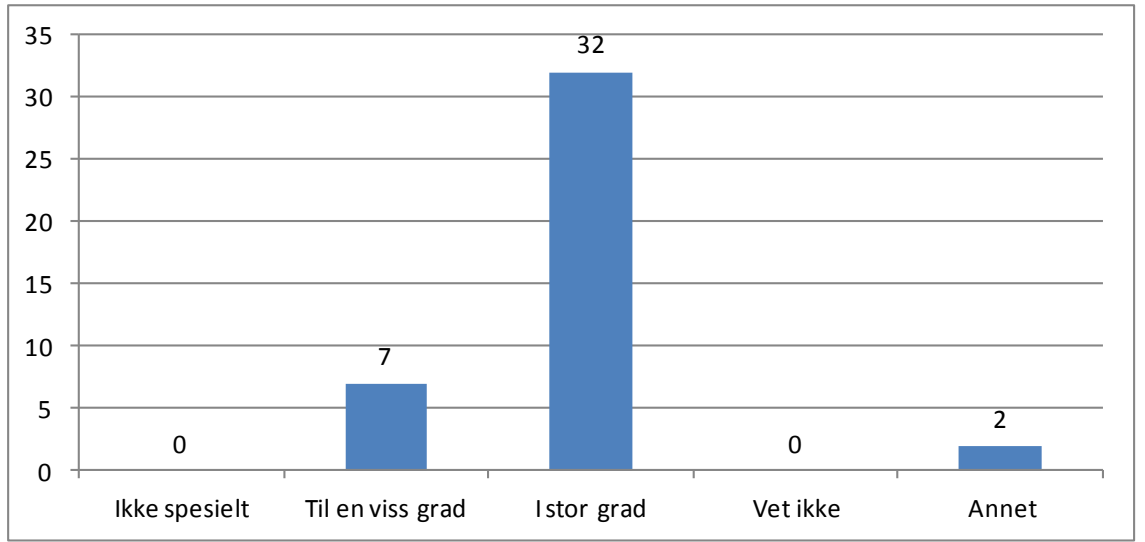

\subsection{Oppsummerende kommentar}

Begrepene sosialt entreprenørskap og sosial innovasjon er relativt nye i Sverige, men har i løpet av de siste 10 årene blitt stadig mer etablerte. De fleste aktørene som i dag gir støtte til området, har også et bredere oppdrag knyttet til støtte til entreprenørskap, foretak eller innovasjon, der støtten til sosial entreprenørskap og sosial innovasjon utgjør en større eller mindre del av virksomheten. Flere av aktørene som gir direkte støtte til entreprenører finnes i tredje sektor, og mange har fra før av, arbeidet med støtte til etablering i den sosiale økonomien. I løpet av den senere tiden har det også kommet til privat drevne aktører som i hovedsak retter seg mot sosiale entreprenører. Flere universitetstilknyttede inkubatorer eller Science Parks utvider og utvikler nye, eller tilpasser eksisterende arbeidsmetoder. Mulighetene til å få støtte til oppstart og utvikling varierer imidlertid over landet. Flere nasjonale myndigheter har i løpet av de siste 10 årene fått oppdrag fra regjeringen hvor målet er å utvikle området. Det har da i første rekke handlet om synliggjøring, utredninger, økt bruk av anskaffelser og fordeling av prosjektmidler. 


\section{Litteratur}

\section{Kapittel 3}

Andersen, Linda Lundgaard (2014). Micro-processes of collaborative innovation in Danish welfare settings: a psychosocial approach to learning and performance. In: Collaborative innovation in the public sector: European experiences and lessons. Bentham EBooks.

Andersen, Linda Lundgaard og Hulgård Lars (2008). Social entrepreneurship i en tværfaglig og problemorienteret belysning. In: Tværfaglighed i entrepreneurship undervisning. København: Øresund Entrepreneurship Academy.

Andersen, Lundgaard L (2012). Frivillighed og social innovation i sundhedsfremmeaktiviteter i Sundhedsfremme i samfunds-og hverdagslivsperspektiv. Betina Dybbroe, Birgit Land, Steen Baagøe Nielsen (red.) Roskilde: Roskilde Universitetsforlag.

Andersen, L.L, Hulgård, L. (2010). Social entrepreneurship - fyrtårne og kuldsejlede projekter. In: Social entrepreneurship. Linda Lundgaard Andersen, Lars Hulgård, Torben Bager (red.). Odense: Syddansk Universitetsforlag, pp.169-177

Andersen, L. L., Hulgård, L. \& Bager. T. (2010). Socialt entreprenørskab. Linda Lundgaard Andersen, Lars Hulgård, Torben Bager (red.). Odense: Syddansk Universitetsforlag.

Alexander, C. (2010). The Third Sector. In: The Human Economy. Hart, K., Laville, J.-L. \& Cattani, A D. Cambridge: Polity Press.

Alvord, S. H., Brown, L. D. \& Letts, C. W. (2003). Social entrepreneurship: leadership that facilitates societal transformation, an exploratory study, Working papers, John F. Kennedy School of Government, Center for Public Leadership, Harvard University.

Anirudh Agrawal; Kai Hockerts (2013). Institutional Theory as a Framework for Practitioners of Social Entrepreneurship. In: Social Innovation: Solutions for a Sustainable Future. Thomas Osburg; René Schmidpeter (eds.). Heidelberg: Springer Science+Business Media B.V. 2013, p. 119-129.

Austin, J., Stevenson, H. \& Wei-Skillern, J. (2006b). Social and commercial entrepreneurship: same, different, or both? In: Entrepreneurship: Theory and Practice, Vol. 30, No. 1 (January).

BEPA-Bureau of European Policy Advisers (2010). Empowering people, driving change: Social innovation in the European Union. Bruxelles: European Commission.

Bergeron, Louis (2011). Honor the Stanford Mission. Stanforf: Standford Report, June $11,2011$.

Borzaga, C. \& Santuari, A. (2003). New Trends in the Non-profit Sector in Europe: The Emergence of Social Entrepreneurship. In: OECD, The Non-profit Sector in a Changing Economy. Paris: 31-56.

Chesbrough, H. (2006). Open Innovation: The New Imperative for Creating and Profiting from Techonology. Boston: Harvard Business School Press.

Dees, J. G. (1998). The Meaning of Social Entrepreneurship. Duke University, Fuqua School of Business. 
Dees, J.G., Emerson, J. \& Economy, P. (eds.) (2002). Strategic Tools for Social Entrepreneurs: Enhancing the Performance of Your Enterprising Nonprofits. New York: John Wiley \& Sons.

Dees, J. G. \& Anderson, B. (2006). Framing a theory of social entrepreneurship: building on two schools of practice and thought. ARNOVA occasional paper series, 1(3), pp. 39-66.

Defourny, J. \& Borzaga, C. (2001). The Emergence of Social Enterprise. London \& New York: Routledge.

Defourny, J., Hulgård, L. \& Pestoff, V. (eds) (2014). Social Enterprise and the Third Sector. New York: Routledge.

Defourny, J. \& Nyssens, M. (2010). Conceptions of Social Enterprise and Social Entrepreneurship in Europe and the United States: Convergences and Divergences. In: Journal of Social Entrepreneurship, Vol. 1, No. 1, pp. 32-53.

Elkington, J. \& Hartigan, P. (2008). The Power of Unreasonable People. Boston: Harvard Business Press.

Evers, A. \& Laville, J.-L. (eds.) (2004). The Third Sector in Europe. Cheltenham and Northampton: Edward Elgar.

Fæster, Monika (2013). Innovationsfeltet mellem samarbejde og styring. En feltanalyse om social værdiskabelse og økonomiske interesser i socialt entreprenørskab. Phd afhandling, Center for Socialt Entreprenørskab, Roskilde Universitet.

Gawell, Malin (2013). Social Entrepreneurship: Action Grounded in Needs, Opportunities and/or Perceived Necessities? Voluntas (2013) 24:1071-1090.

Gilbert, N. (2002). Transformation of the Welfare State. The silent surrender of public responsibility. Oxford: Oxford University Press.

Granovetter, M. (1973). The Strength of Weak Ties. American Journal of Sociology, 78 (6): 1360-80.

Gustavsen, Karin \& Kobro, U. Lars (2012). Sosialt entreprenørskap som ledd i innsatsen mot fattigdom. Telemarksforskning, TF-rapport nr. 305.

Habermas, J. (1981). Theorie des kommunikativen Handelns, bd. 1 \& 2, Frankfurt am Main: Suhrkamp Verlag.

Habermas, J. (1996). Between Facts and Norms. Cambridge: Polity Press.

Hart, K., Laville, J.-L. \& Cattani, C. (2010). The Human Economy. London: Polity Press.

Henton, D., Melville, J. \& Walesh, K. (1997). Grassroots Leaders for a New Economy How Civic Entrepreneurs Are Building Prosperous Communities. San Francisco: Jossey Bass Publishers.

Hockert, Kai \& Wünstenhagen (2010). Greening Goliaths versus emerging Davids Theorizing about the role of incumbents and new entrants in sustainable entrepreneurship. Journal of Business Venturing, Vol 25, No 5, pp 481-492.

Hulgård, L. (2004). Entrepreneurship in Community Development and Local Governance. In: Bogason, P., Kensen, S. \& Miller, H. (eds) Tampering with Tradition: The Unrealized Authority of Democratic Agency. Lanham: Lexington Books.

Hulgård, L. (2007). Sociale entreprenører - en kritisk indføring. Copenhagen: Hans Reitzels Forlag.

Hulgård, L., Andersen, L. L., Spear. R. \& Bisballe. L. (2008). Alternativ beskæftigelse og integration af socialt udsatte grupper: erfaringer fra Danmark og Europa. CSE Publications; 02:08). Roskilde: Roskilde Universitet.

Hulgård, L., (2010). Public and social entrepreneurship. In: The Human Economy Hart, Laville and Cattani (eds.). London: Polity Press. 
Hulgård, L. (2010) Discourses of social entrepreneurship: variations of the same theme? In: Defourny, J., Hulgård, L. \& Pestoff, V. (eds) Social Enterprise, Social Entrepreneurship, Social Economy, Solidarity Economy: An EMES Reader on the "SE Field". Liege: EMES European Research Network.

Hulgård, L. (2011). Social economy and social enterprise: an emerging alternative to mainstream market economy? In: China Journal of Social Work. Vol. 4, No 3, November 2011. Hong Kong Polytechnic University and Peking University: Routledge.

Hulgård, L. \& Andersen, L. L. (2012). Socialt entreprenørskab - velfærdsafvikling eller arenaer for solidaritet. Dansk Sociologi, vol. 23, nr. 4. 2012.

Hulgård, L. \& Shajahan, P.K. (2012). Social Innovation for People-Centred Development. In: Moulaert, MacCallum, Mehmood, Hamdouch, (eds.) Handbook on Social innovation: Collective action, Social learning and Transdisciplinary research. Southhampton: Edward.

Janoski, T. (1998). Citizenship and Civil Society. Cambridge: Cambridge University Press. Kerlin, J. A. (ed.) (2009). Social Enterprise: A Global Comparison. Lebanon: Tufts University Press.

Kirketerp, Anne (2010). Pædagogik og didaktik i entreprenørskabsundervisningen på de videregående uddannelser $i$ et foretagsomhedsperspektiv. Phd afhandling, Center for Entreprenørskab, Århus Universitet.

Koskiaho, Briitta (2014). Kumppanuuden sosiaalipolitiikkaa etsimässä. United Press Global, s 173-174.

Kulothungan, Gladius (2014). Genesis of Social Entrepreneurship. An Exploration Through Case Studies. Phd thesis, Center for Social Entrepreneurship, Roskilde University.

Krull, Per (2013). Designtænknings bidrag til sociale virksomheders værdiskabelse - et casestudie. Ph.d-afhandling, Business and Social Sciences, Aarhus University.

Laville, J-L. (2010) Solidarity Economy. In: Hart, K., Laville, J.-L. \& Cattani, A D, The Human Economy. Cambridge: Polity Press.

Leadbeater, C. (1997). The Rise of the Social Entrepreneur. Demos: London.

Leadbeater, C. (2006). The Socially Entrepreneurial City. In: Nicholls, A. (ed.) Social Entrepreneurship: New Models of Sustainable Social Change. Oxford: Oxford University Press, pp. 233-46.

Leadbeater, C. (2007) Social enterprise and social innovation: Strategies for the next ten years: A social enterprise think piece for the Office of the Third Sector. Cabinet Office, Office of the Third Sector.

Leadbeater, C. (2009). We-think. Croydon: Profile Books.

Levander, Ulrika (2012). Utanförskap på entreprenad. Phd afhandling, Göteborg Universitet.

Light, P. (2008). The Search for Social Entrepreneurship. Washington, D.C.: Brookings Institution Press.

Mair, Johanna \& Noboa, Ernesto (2003). The Emergence of Social Enterprises in the new Organizational Landscape. Working Paper No 523, IESE Business School, University of Navarra., pp. 1-13.

Mair, J. (2010). Social entrepreneurship: taking stock and looking ahead. In: Fayolle, A. \& Matley, H. Handbook of Research on Social Entrepreneurship. Cheltenham: Edward Elgar.

Mandag Morgen (2010). Velfærdens iværksættere - en dansk strategi for socialt iværksætteri. 1. udgave Mandag Morgen. www.mm.dk/velfærdens-iværksættere 
Mawson, A. (2008). The Social Entrepreneur - Making Communities Work. London: Atlantic Books.

Moulaert, F., MacCallum, D., Mehmood, A. \& Hamdouch, A. (eds) (2012). International Handbook on Social Innovation: Collective Action, Social Learning and Transdisciplinary Research. Southhampton: Edward Elgar.

Moulaert, F., Jessop, B., Hulgård, L., \& Hamdouch, A. (2012). Social Innovation: A new stage in innovation process analysis? In: Moulaert, MacCallum, Mehmood, Hamdouch (eds.) Handbook on Social innovation: Collective action, Social learning and Transdisciplinary research. Southhampton: Edward.

Mulgan, G. (2006). The Process of Social Innovation. In: Innovations: Technology, Governance, Globalization, Vol. 1, No. 2, pp. 145-62.

Mulgan, G. (2007). Social innovation. What it is, why it matters and how it can be accelerated. London: Young Foundation.

Nicholls, A. (2008) (ed.). Social Entrepreneurship: New Models of Sustainable Social Change. Oxford: Oxford University Press.

Nyssens, M. (2006) (ed.). Social Enterprise. At the crossroads of market, public policies and civil society. London: Routledge.

Osborne, S. (ed.) (2010). The New Public Governance? Emergiing perspectives on the theory and practice of public governance. London \& New York: Routledge.

Pestoff, V. (2009). A Democratic Architecture for the Welfare State. London: Routledge. Victor Pestoff (2014) Hybridity, Coproduction, and Third Sector Social Services in Europe. American Behavioral Scientist. Published online 16 May 2014.

Pestoff, V. \& Brandsen, T. (2009). Co-Production, the Third Sector and the Delivery of Public Services. London \& New York: Routledge.

Pestoff V. (2009). Social Enterprise, the Third Sector, Democracy and the Welfare State - a Scandinavian Perspective. Presented at the 2nd CIRIEC International Research Conference of Social Enterprise, Östersund, Sweden, 1-2 October, 2009.

Petersen, O. K. (2011). Konkurrencestaten. København: Hans Reitzels Forlag.

Phills, J. A., Deiglmeier, K. \& Miller, D. T. (2008). Rediscovering Social Innovation. In: Stanford Social Innovation Review, Fall.

Putnam, R. (1999). Interview. Unpublished interview by Lars Hulgård.

Regeringskansliet (1998). Social eknomi I EU-landet Sverige - tradition och förnyelse i samma begrepp. Stockholm: Regeringskansliet.

Ridley-Duff, R. \& Bull, M., (2011). Understanding Social Enterprise. Theory and Practice. London: Sage Publications.

Rosenberg, Charlotte: SydhavnsCompagniet - Tilblivelser, relationer og muligheder $i$ stribede og glatte rum. Ph.d.-afhandling, Forskerskolen i Livslang Læring, Institut for Psykologi og Uddannelsesforskning, Roskilde Universitet

Schumpeter, J. A. (1934). The Theory of Economic Development. Cambridge: Harvard University Press.

Seppelin, M. (2014). Det nordiska perspektivet på socialt entreprenörskap, Oplæg til Arbejdsgruppe om Socialt Entreprenørskab nedsat af Nordisk Ministerråd, Helsinki: Ministry of Social Affairs and Health.

Steyart, C. \& Hjorth, D. (2006) (eds.). Entrepreneurship as Social Change. Cheltenham: Edward Elgar.

Sundin, Elisabeth og Tillmar, Malin (2010). The Intertwining of social, commercial and public entrepreneurship. Pp. 109-124. In: Fayolle, A., Matlay, H. (eds.). Handbook of Research on Social Entrepreneurship. Edward Elgar. 
Svendsen Gunnar Lind. Haase \& Gert Tinggaard Svendsen (2004). The Creation and Destruction of Social Capital - Entrepreneurship, Co-operative Movements and Institutions. Cheltenham: Edward Elgar.

Swedberg, R. (2000). Entrepreneurship. The Social Science View. Oxford: Oxford University Press.

Sørensen, A. \& Fredriksen, A. H. (2010). Sociale opfindelser. Socialt Udviklingscenter SUS.

Taylor, M. (2003). Public Policy in the Community. Houndsmills: Palgrave Macmillan. The Economist (2013). Special Report: The Nordic Countries - the next supermodel. In: The Economist, February 2nd, 2013.

Trädgårdh, L. et al (eds.) (2013). Civilsamhället klämt mellan stat och kapital. Stockholm: SNS Förlag.

Utredning om sosialt entreprenørskap. Utarbeidet av DAMVAD for Nærings- og Handelsdepartementet Desember 2011.

Wijkström, F. \& Zimmer, A. (eds.) (2011). Nordic Civil Society at a Cross-Roads. Baden-Baden: Nomos Verlagsgesellschaft.

Wijkström, F. (2011). Charity Speak and Business Talk. The On-Going

(Re)hybridization of Civil Society. In: Wijkström, F. \& Zimmer, A. (eds.) (2011). Nordic Civil Society at a Cross-Roads. Baden-Baden: Nomos Verlagsgesellschaft.

Yunus, M. (2007). Creating a World without Poverty. New York: Pulic Affairs.

\section{Kapittel 4}

Friestad, Christine \& Skog Hansen, Inger Lise (2004). Levekår fengsler. Levekår blant innsatte. Fafo-rapport 429, 2004.

Gudjonsson, G. H., Sigurdsson, J.F., Einarsson, E., Bragason, O.O., \& Newton, A.K. (2008): Interrogative suggestibility, compliance and false confessions among prisoners and their relationship with attention deficit hyperactivity disorder (ADHD) symptoms. In: Psychological Medicine, 38 (2008), pp. 1037-1044

Nilsson, A. (2003). Living Conditions, Social Exclusion and Recidivism Among Prison Inmates. In: Journal of Scandinavian Studies in Criminology and Crime Prevention, 4/1: 57.

Skardhamar, Torbjørn \& Kjetil Telle (2009). Life after prison. The relationship between employment and re-incarnation. Discussion paper No. 597, Statistics Norway.

\section{Kapittel 5}

Ármannsdóttir, Á. (2010). The Icelandic Social Entrepreneur. Cand. Merch. thesis. Aarhus. Business School.

Kristmundsson, Ómar H. \& Hrafnsdóttir, Steinunn (2012). The Role of Non-profit organizations in the development and provision of welfare services in Iceland. Moving the Social. In: Journal of Social History and the History of Social Movements. $48,179-192$. 


\section{Kapittel 7}

Hämäläinen, Timo \& Heiskala, Risto (2004). Sosiaaliset innovaatiot ja yhteiskunnan uudistumiskyky. Sitra 271. Edita Publishing Oy. Helsinki 2004.

Koskiaho, Briitta (2014). Kumppanuuden sosiaalipolitiikkaa etsimässä. United Press Global, pp 159-172; 187-195.

\section{Kapittel 8}

Kristmundsson, Ómar H. \& Hrafnsdóttir, Steinunn (2012). The Role of Non-profit organizations in the development and provision of welfare services in Iceland. Moving the Social. In: Journal of Social History and the History of Social Movements. $48,179-192$. 


\section{Summary}

This report presents the results from a survey of initiatives to support social entrepreneurship and social innovation in the Nordic Region.

The survey addresses the challenges faced by the Nordic countries with regard to maintaining and further developing social welfare. The Nordic Council of Ministers (NMR) has put these challenges on the agenda on a number of occasions. In autumn 2012 the Norwegian Presidency organised a Nordic seminar on social entrepreneurship. One experience from this seminar was that there are different types of initiative and support for promoting social entrepreneurship in the Nordic countries, so there should also be a potential for mutual learning.

Against this background, NMR decided in summer 2013 to appoint a working group to survey initiatives to support social entrepreneurship and social innovation. All five Nordic countries and the self-governing areas, were invited to take part. Responsibility for the project was assigned to the Norwegian Ministry of Labour and Social Affairs.

Two members from each country were appointed in autumn 2013. The members have a background in administration, research and education. The self-governing areas opted not to take part.

The main purpose of the survey was to increase knowledge of initiatives to support social entrepreneurship and social innovation in the Nordic Region in the work to include disadvantaged groups in employment and society.

The working group's mandate was twofold: In the first phase, the working group was to define terminology and the subject matter for its work, including identifying what part of Nordic cooperation could add value to the work already being done in the Nordic countries and the EU. In the second phase, initiatives to support social entrepreneurship and social innovation in the Nordic countries would be surveyed.

This report presents the results from the work that was carried out. It is made up of three parts.

Part 1 presents the background, purpose and principal contents of the report. Chapter 1 presents the background and main aims of the survey together with the working group's understanding of its mandate and the terms social entrepreneurship and social innovation, while in chapter 2 the working group makes recommendations for further follow-up. 
Part 2 puts the survey in a broader context. Chapter 3, which the working group commissioned Professor Linda Lundgaard Andersen and Professor Lars Hulgård of Roskilde University to write, deals with the terms social entrepreneurship and social innovation. The authors first look at how these terms have been defined in the literature and then present some Nordic perspectives. Chapter 4 provides an overview of the challenges involved in including disadvantaged groups in employment and society in the Nordic Region.

Part 3 presents the results from the survey, with the results from the Nordic material as a whole being presented in chapter 5 and the results for each country in chapters 6-10.

\section{Social entrepreneurship, social enterprises and social innovation}

In the working group's mandate, social entrepreneurship is understood as a type of enterprise with the following three characteristics:

- It is targeted at a social objective where there is an unmet welfare need.

- It contributes innovative solutions to these challenges.

- It is driven by the social results, but also by a business model that can make the enterprise viable and sustainable.

We chose to base our work on this understanding and bring in another two characteristics:

- Involvement of the target group for the social entrepreneurial work, the employees and other key stakeholders.

- Cooperation across disciplines and business models.

We have already pointed out that the mandate links social entrepreneurship with business methods. In our assessment, social entrepreneurial processes and work can also be found in established (public) institutions and non-profit organisations. Social enterprises may be characterised by social entrepreneurship, but not necessarily. Social entrepreneurship and social innovation as we know them today are also closely linked, but can also be two totally separate areas. This means that social innovation can be achieved without being preceded by social entrepreneurship. The terms social entrepreneurship, social enterprises and social innovation are looked at in more detail in chapter 3. 


\section{Carrying out the survey}

It follows from the mandate that the survey must make a point of bringing out the scope and variety of initiatives, and it must provide a description of the initiatives, not an assessment.

None of the Nordic countries has a register of any sort or other forms of documentation for initiatives to support social entrepreneurship and social innovation. Therefore, respondents were selected by each country's members drawing up lists based on their own knowledge in the field, networks and internet searching. It was also possible for the respondents to suggest other respondents or withdraw if they did not consider their own activities relevant.

A review of the terms used in administration and other practice in the five countries revealed that the extent to which the terms social entrepreneurship and social innovation are known and used varies. The review also revealed that several other terms are used that partly overlap with the understanding in the mandate, but not entirely. We therefore chose an open approach to which initiatives should be included. Thus the survey includes not only initiatives that are targeted directly at social entrepreneurship and social innovation, but also initiatives that may promote them without these terms being used.

The survey was carried out in May and June 2014. We sent a questionnaire out to a total of 193 respondents and received 131 replies, roughly two thirds of the invitees. We have no reliable information on why some invitees chose not to take part. We are nevertheless of the opinion that, overall, the data collected contains good breadth and variety of initiatives. Initiatives in the public, private and third sector, and in all the categories specified in the mandate, were surveyed in all the countries.

The questionnaire contained a combination of structured and open questions. The report not only presents an overview of the types of initiative that exist and their characteristics, but gives examples of how the initiatives work. All the examples used were chosen to illustrate the scope and variety of what a particular type of initiative can mean in practice. An assessment of the various initiatives is beyond the scope of this survey.

\section{The types of initiative surveyed}

The survey shows that there is a broad spectrum of initiatives in the Nordic countries.

Examples of the following types of initiative were surveyed in all the countries: Funding, advice/competence development, incubation, network building, research \& development, education, increasing visibility, lobbying, legal framework, strategic development work and safeguarding business interests. 
The survey also reveals that most respondents have key initiatives that are followed up by other initiatives in order to support the key initiative. All respondents ticked at least two types of initiative, most more than two, with some replying that they offer all types of initiative.

Both the material collected and the data for each country contained most examples of advice/competence development, increasing visibility and network building. Initiatives focusing on advice/competence development include different types of course and other training, conferences, workshops, guidance and advice provided through board membership. Network building involves the creation of fixed structures around defined networks (network associations), ad hoc groups set up in various organisations, and the use of workshops and seminars. Increasing visibility is about several of the same activities and various forms of knowledge sharing.

Examples of initiatives in all the categories surveyed can be found in chapters 5-10.

This general picture conceals considerable variation between the countries. Among other things, this applies to the number of initiatives surveyed in each category and the characteristics of the various initiatives. In some cases a country may have just one example within a category, while other countries have a large number of examples. As in the education category, for example, it might be anything from a master's programme in social entrepreneurship at a university to lesser and shorter courses.

There is also considerable variation in the purpose and target group of initiatives. As previously mentioned, the extent to which the terms social entrepreneurship and social innovation are known and used varies between the Nordic countries. This is also reflected in the initiatives surveyed.

In the Danish, Swedish and Norwegian material we find several examples of both initiatives targeted directly at social entrepreneurship and social innovation in the work to include disadvantaged groups in employment and society, and initiatives targeted directly at social entrepreneurship and social innovation in general. Also, in Denmark we see more of the initiatives being associated with the term social enterprises, while the terms work integration social enterprises and social entrepreneurship are used more in Sweden.

The Finnish material collected contains no separate social entrepreneurship and social innovation initiatives, but examples of initiatives to promote employment and business, initiatives to foster social enterprises, and initiatives to include disadvantaged groups in employment and 
society. ${ }^{77}$ The Icelandic material does not contain any separate social entrepreneurship and social innovation initiatives either, but initiatives targeted at entrepreneurship and innovation, and initiatives targeted at third sector organisations working for the inclusion of disadvantaged groups in general. These initiatives can contribute to social entrepreneurship and social innovation despite not targeting them specifically.

It is our general impression that initiatives targeted directly at social entrepreneurship and social innovation in the work to include disadvantaged groups in employment and society are of more recent date.

\section{The extent to which initiatives focus on the characteristics of social entrepreneurship}

As previously mentioned, we chose to highlight four characteristics in our understanding of social entrepreneurship. They are the development and trialling of new solutions, involvement of the target group for the social entrepreneurial work, cooperation across disciplines and business models, and sustainability (economic and socio-economic).

The overall material shows that a large proportion of the respondents focus on these characteristics "to some extent" or "to a large extent". The proportion varies from around 80 percent for involvement of the target group to over 90 percent for new solutions. There is some variation between countries, but not to any great extent.

The four characteristics of social entrepreneurship therefore seem to be something that the respondents focus on even if the initiative does not target social entrepreneurship directly.

\section{How respondents assess obstacles and the need for new initiatives}

The respondents were asked for their assessment of the most important obstacles to social entrepreneurship and social innovation, and the need for new initiatives. Their replies can and must be understood on the basis of the national context and the areas in which they work. At the same time, the general impression is that many of the same obstacles and needs are to be found in the answers given by respondents in all the countries. These fall into the following main categories:

- Lack of access to funding and inadequate or non-existent support structures: To deal with these challenges, respondents pointed to the

77 The data may be flawed owing to the low response to the questionnaire survey in Finland. 
need for better funding options from both government and other sources.

- Regulations and their implementation: Attention was drawn to the particular challenges linked to public procurement regulations and their implementation. Respondents highlighted the need for changes in these regulations and greater emphasis on quality, social responsibility and social value.

- Lack of awareness of social entrepreneurship and social innovation: Respondents pointed to a lack of awareness in society in general and among public authorities in particular. To deal with these challenges, respondents mentioned a wide range of initiatives, including research and education, analysis and exchange of experiences with good examples, and information campaigns.

- Attitude, culture and organisation in government: Respondents say that there is a conflict between the cross-sectoral, interdisciplinary nature of social entrepreneurship and the way public players are organised in specialised units. They also comment that there is a lack of competence and incentives for working cross-sectorally. To deal with these challenges, they highlight the need for a more detailed examination of how structures and systems can be made less rigid so as not to impede social entrepreneurship. There is a need for closer cooperation between public authorities and the private and voluntary sectors on solving welfare challenges.

\section{The working group's recommendations for further follow-up}

Social entrepreneurship and social innovation have been attracting growing attention and interest for several years. The EU has taken the initiative for a number of programmes and measures to promote activity in the area. This report gives a small insight into the initiatives that exist in the Nordic countries to support social entrepreneurship and social innovation with the emphasis on initiatives of relevance to the work to include disadvantaged groups in employment and society.

Our assessment is that the challenges shared by the Nordic countries with regard to further development of the Nordic welfare model make it both relevant and of interest to pursue further joint Nordic cooperation that takes account of the Nordic perspective. The characteristics of social entrepreneurship and interaction with a broad public sector in the Nordic countries may differ from similar interaction in countries with other welfare models. Joint Nordic cooperation can take place in various areas and ways. 
In this context we present a number of recommendations for further follow-up. The recommendations are based on our experiences in the course of this work, respondents' replies and the expertise of the working group as a whole.

1. Terms and understanding - establish a better common basis for further cooperation. In our experience, different terms and definitions in this field can in some cases result in difficulties in knowing what is being discussed and whether the terminology is understood in the same way in general and in different countries.

- Work should be initiated with a view to making terms and definitions used in the Nordic countries in this area better known and understood.

- NMR should identify some characteristics of social entrepreneurship to be used as a basis for its own work in this area.

2. Practice - promote the exchange of experiences with different types of initiative. The survey presented in this report gives a small insight into the scope and variety of initiatives in the Nordic countries. What about experiences with these initiatives? To what extent do the initiatives contribute to set goals and how well do they deal with the challenges encountered by social entrepreneurs?

- A Nordic conference should be held with a view to exchanging knowledge and experience regarding different types of social entrepreneurship and social innovation initiative.

3. Research and education - enhance the knowledge base. In chapter 3 , Lars Hulgård and Linda Lundgaard Andersen provide a brief status report on research and analysis in the field in the Nordic countries. The field is relatively new, and several topics and problems of common Nordic relevance are pointed up. The need for increased awareness of social entrepreneurship and social innovation is also highlighted by the survey respondents.

- Work should be initiated with the purpose of strengthening research and higher education in the field in the Nordic countries. The work should be divided into two phases: First, a survey should be conducted into the research and higher education that already exists. Then an assessment should be made of a possible design for a joint Nordic research programme with the emphasis on topics of special relevance to the Nordic countries, and of 
possible measures for developing existing higher education provision.

4. Research and development - establish a joint Nordic centre for knowledge exchange and dissemination. The survey provides examples of several communities - both large, well-established and other, smaller ones - that are working on research, knowledge development and the dissemination of knowledge and experiences in the field. Some of these communities have established cooperation with other countries in the Nordic Region, and research cooperation between several of the Nordic countries has also been set up through the SERNOC research network. In our assessment, this cooperation should be built on.

- A joint Nordic centre for knowledge development and dissemination of knowledge and experiences in the field should be established. The centre can be physical and/or virtual and build on Nordic and/or national structures and cooperation.

5. Policy - increased cooperation between sectors and ministries. Lack of cross-sectoral cooperation and a silo mentality in government is highlighted as an obstacle to social entrepreneurship and social innovation in all the countries. Given the political desire to contribute to the development and enhancement of social entrepreneurship and social innovation, we see a need to address the area at a more crossdepartmental and strategic level.

- National authorities should be urged to address the area at a more cross-departmental and strategic level. Relevant topics for crossdepartmental cooperation include experiences and challenges linked to the procurement regulations, and different funding solutions and other support structures for social entrepreneurship and social innovation.

6. Social entrepreneurship, socio-economic enterprises, social enterprises and social innovation as a subject in vocational education. Social entrepreneurship, social enterprises and social innovation are affecting many areas of society, and therefore different professional groups, to an increasing extent. It is our impression that this is not currently reflected in syllabuses, course literature, etc.

- National authorities should be urged to assess the need for development of this area. 


\section{Vedlegg 1}

\section{Eksempler på begreper og definisjoner i de nordiske landene}

Arbeidsgruppen foretok i den innledende fasen av arbeidet er gjennomgang av begreper og definisjoner som benyttes i de nordiske landene. Gjennomgangen viste at det benyttes en rekke forskjellige begrep som delvis, men ikke helt overlapper forståeslen i mandatet.

Her er noen eksempler.

\subsection{Danmark}

Fra Danmark kan nevnes begrepet "socialøkonomisk virksomhed". Udvalget for socialøkonomiske virksomheder definerte dette begrepet på følgende måte:

"Socialøkonomiske virksomheder er private og driver erhverv med det formål gennem deres virke og indtjening at fremme særlige sociale formål. Socialøkonomiske virksomheder forstås som virksomheder, der lever op til følgende fem kriterier:

- Socialt formål - virksomhedens primære formål har samfundsgavnlig karakter; det vil sige, at formålet har et socialt, beskæftigelses-, sundheds-, miljømæssigt eller kulturelt sigte, som desuden fremmer aktivt medborgerskab.

- Væsentlig erhvervsdrift - virksomheden har et væsentligt element af erhvervsdrift ved salg af serviceydelser eller produkter, som udgør en betydelig del af dens omsætning.

- Uafhængig af det offentlige - virksomheden har eget CVR-nummer og fungerer uden væsentlig offentlig indflydelse på ledelsen og driften af virksomheden.

- Social overskudshåndtering - virksomheden anvender hele sit overskud til primært at fremme sociale formål, reinvestere i egen 
eller andre socialøkonomiske virksomheder og sekundært til begrænset udbetaling af udbytte til investorer.

- Ansvarlig og inddragende virksomhedsledelse - virksomheden er transparent i sit virke og har en værdiskabende og etisk forsvarlig ledelse.".

\subsection{Sverige}

Fra Svergie kan nevnes begrepet "samhällsentreprenörskap" som defineres på følgende måte:

"En samhällsentreprenör tar ett innovativt initiativ för att utveckla samhällsnyttiga funktioner. En samhällsentreprenör är en entreprenör med samhällsnytta som mål."

Fra Sverige kan også nevnes begrepet "arbetsintegrerande sociale företag" som av den svenske regjeringen defineres på følgende måte:

"Företag som driver näringsverksamhet med övergripande ändamål att integrera människor som har stora svårigheter att få och/eller behålla ett arbete, i arbetsliv och samhälle:

- som skapar delaktighet för medarbetarna genom ägande, avtal eller på annat väl dokumenterat sätt

- som i huvudsak återinvesterar sina vinster i de egna eller liknande verksamheter

- som är organisatoriskt fristående från offentlig verksamhet.".

Arbeidsintegrende sosiale foretak forstås som et uttrykk for samfunnsentreprenørskap.

\subsection{Island}

I Island er det en lang tradisjon for non-profit organisasjoner som engasjerer seg i sosialt entreprenørskap og sosial innovasjon. Det finnes ingen offisiell definisjon av begrepet sosialt entreprenørskap. Innovasjonssenteret på Island (som er en offentlig drevet organisasjon) definerer sosial innovasjon på følgende måte:

"Ideas and plans which meet societial needs and can lead to increased welfare and standard of living in communites. According to their understanding social innovation is not different from traditional innovation 
except that it relies on certain assumptions and ideas about honesty, ethics, sustainability and justice. Iceland participated in the GEM study of se in the year 2009 and they define se as a process of value creation, where resources are combined in new ways and used to exploit an opportunity with the aim of creating social value by stimulating social change or meeting social needs and involves the offering of services and products but can also refer to the creation of organization."

\subsection{Finland}

Fra Finland kan nevnes begrepene "sociala företag" og "samhälliga företag". Sosialt foretak er definert i en lov om sosiale foretak på følgende måte:

"Ett socialt företag är en näringsidkare som är registrerad i registret över sociala företag:

1. som införts i handelsregistret i enlighet med ovan nämnda lag

2. som producerar nyttigheter enligt företagsekonomiska principer

3. av vars anställda arbetstagare minst 30 procent är sådana personer som avses i $1 \S 1$ punkten eller sammanlagt minst 30 procent sådana personer som avses i 1 § 1 punkten och andra personer som avses i 1 $\S$ (andel sysselsatta), och (28.12.2012/924)

4. som till alla sina anställda arbetstagare, oberoende av dessas produktivitet, betalar lön på basis av full arbetsförmåga enligt det kollektivavtal som tillämpas i branschen i fråga, eller, om ett sådant kollektivavtal inte finns, betalar gängse och skälig lön för arbetet i fråga.

Sociala företag enligt denna lag erbjuder arbetsmöjligheter i synnerhet åt personer:

1. som har en skada eller sjukdom som försvårar deras sysselsättning

2. som har varit arbetslösa arbetssökande utan avbrott i tolv månader eller som i flera perioder av arbetslöshet har varit arbetslösa arbetssökande i sammanlagt minst tolv månader och på grundval av upprepad arbetslöshet och den tid arbetslösheten totalt har varat kan jämställas med arbetssökande som utan avbrott varit arbetslösa i tolv månader 
3. som har fått arbetslöshetsförmån på grund av arbetslöshet under minst 500 dagar.".

"Ett samhälleligt företag" märket beviljas av Komissionen för ett samhälleligt företag. De företag som anhåller om märket genomgår en helhetsanalys på basen av kriterierna i stadgarna för märket. I analysen betonas de tre primärkriterierna, men den betraktar även hur de övriga egenskaperna, som beskriver ett samhälleligt företag kommer fram i kandidatföretagets verksamhet.

Kriterier för beviljande - primärkriterierna:

- Ett samhälleligt företags primära uppgift och målsättning är att producera välfärd i samhället. Ett samhälleligt företag bedriver en ansvarsfull affärsverksamhet.

- Begränsad vinstutdelning. Samhälleliga företag använder, i enlighet med sin affärsidé, största delen av sin vinst till att producera samhälleig välfärd, genom att utveckla sin verksamhet, eller genom att donera vinsten i enlighet med denna.

- Affärsverksamhetens öppenhet och transparens. För att säkerställa transparensen, måste företaget, som ansöker om märket förbinda sig att lägga företagets samhälleliga målsättning och begränsade vinstudelning till sin bolagsordning eller sina stadgar.

Förutom de ovan beskrivna centrala egenskaperna som beskriver en samhällelig företagsverksamhet, kan en eller flera av följande egenskaper förenas med företaget: lojalitet mot personalen, förbindelse att utveckla arbetshälsa, trivsel i arbetet och personalens möjligheter att påverka, en kundorienterad utveckling av affärsverksamheten och fasta kontakter med företaget närstående samfund, en minimering av verksamhetens hälso- och miljöpåverkan, utvecklande av lokalekonomin, ett speciellt beaktande av personer i en svagare ställning samt en påvisbar samhällelig inverkan."

\subsection{Norge}

Fra Norge kan nevnes forståelsen som ligger til grunn i regelverket for et tilskudd til sosial entreprenørskap. Formålet med ordningen er å stimulere til utvikling av sosialt entreprenørskap rettet mot fattigdom og sosial eksklusjon i Norge. Målet er også å stimulere til at egenorganiserte som har 
erfart fattigdom og sosial eksklusjon, bidrar til utvikling av sosialt entreprenørskap, der erfaringsbasert kunnskap og kompetanse er relevant.

Følgende aktører kan søke om midler:

- De må selv definere seg som sosiale entreprenører.

- De er virksomheter med mål å løse sosiale problemer på en ny måte.

- Det er vedtektsfestet at det ikke skal tas utbytte.

- De drives av de sosiale resultatene, og også av en forretningsmodell som kan gjøre virksomheten levedyktig og bærekraftig drift etter noe tid.

- De er registrert i Frivillighetsregisteret (organisasjonsformen kan f.eks. være AS, stiftelse eller frivillig organisasjon. 



\section{Vedlegg 2 Følgebrev}

\section{Invitasjon til å delta $\mathrm{i}$ kartlegging av innsatser for sosialt entreprenørskap og sosialt innovasjon i Norden}

(Navn til organisasjonen) inviteres herved til å delta i en kartlegging av innsatser for å legge til rette for sosialt entreprenørskap og sosial innovasjon i Sverige, Norge, Danmark, Finland og Island. Kartleggingen fokuserer særlig på sosialt entreprenørskap og innovasjon av relevans for arbeidet for å inkludere utsatte grupper i arbeid og samfunnsliv.

Kartleggingen inngår i programmet Holdbar Nordisk Velferd under Nordisk Ministerråd. En arbeidsgruppe med deltakelse fra de fem nordiske landene har ansvaret for gjennomføringen. Se her for nærmere informasjon om mandatet til arbeidsgruppen. http://www.norden.org/no/ tema/ haallbar-nordisk-vaelfaerd/utdanning-og-arbeid-for-velferd/socialtentreprenoerskap

Sosialt entreprenørskap og sosial innovasjon handler om å utvikle og ta i bruk nye løsninger på sosiale og samfunnsmessige problemer. Det handler om å utvikle nye nettverk på tvers av fagfelt og virksomhetsmodeller der partene samspiller på nye måter.

Sosialt entreprenørskap og sosial innovasjon kan være rettet mot et bredt spekter av sosiale formål. Denne kartleggingen fokuserer særlig på innsatser for å legge til rette for sosialt entreprenørskap og sosial innovasjon av relevans for arbeidet for å inkludere utsatte grupper i arbeid og samfunnsliv. Sosial innovasjon kan være et resultat av sosialt entreprenørskap, men også av andre former for virksomhet.

Formålet med denne kartleggingen er ikke å samle inn informasjon om alle innsatser innenfor denne avgrensningen. Målet er å synliggjøre bredde og variasjon i de mange forskjellige typer innsatser som finnes i de nordiske landene. Med "innsatser" forstås både rammebetingelser, virkemidler tiltak og aktiviteter. Med "å tilrettelegge" forstås å bidra til at et mål nås.

Arbeidsgruppen har med utgangspunkt i sin kunnskap om feltet, nettverk og nettsøk utarbeidet en liste over aktører som er identifisert som ansvarlig for en eller flere relevante innsatser. Din organisasjon er 
blant aktørene på denne listen, og vi håper at organisasjonen har anledning til å delta. Dere finner spørreskjemaet ved å følge denne lenken (legg inn lenke). Beregnet tid til å svare på spørsmålene er x minutter.

Har du spørsmål til kartleggingen, ta gjerne kontakt med (navn på person, tlf. nr og e-postadresse.)

Hvis din organisasjonen ikke har ansvar for/arbeider med innsatser av relevans for kartleggingen, ber vi deg gi tilbakemelding til ovennevnte e-postadresse om at det ikke er aktuelt å delta.

Vi takker for din deltakelse!

Med vennlig hilsen

(navn på deltakerne i arbeidsgruppen fra det aktuelle landet) 


\section{Vedlegg 3 Spørreskjema}

\section{Nordisk kartlegging av innsatser for sosialt entreprenørskap og sosial innovasjon}

\section{Les her før du starter utfylling av spørreskjemaet}

Dette spørreskjemaet inneholder noen spørsmål med faste svaralternativer og noen åpne spørsmål for supplerende informasjon.

De fleste spørsmålene gjelder kjennetegn ved innsatsen(e) din organisasjon har ansvar for eller arbeider med. Med innsats forstås rammebetingelser, virkemidler, tiltak og aktiviteter.

Din organisasjon kan ha ansvar for en eller flere innsatser, og en innsats kan bestå av ulike elementer. Spørreskjemaet fylles uansett ut kun én gang. Hvis svaret vil være forskjellig for ulike innsatser/elementer i en innsats, synliggjøres det i de åpne feltene.

Vi håper dere vil beskrive innsatsen(e) så grundig som mulig. Legg gjerne ved link til nettside under de åpne spørsmålene. Formålet er å gi oss de beste forutsetninger for å forstå og beskrive bredden og mangfoldigheten av innsatser for å legge til rette for sosialt entreprenørskap og sosial innovasjon i de nordiske landene.

Vi stiller også to spørsmål om dine vurderinger av hindre for sosialt entreprenørskap og sosial innovasjon og dine vurderinger av behovet nye innsatser i eget land. Svarene på disse spørsmålene skal kun benyttes som en del av grunnlaget for arbeidsgruppens forslag til videre oppfølging på området. Svarene vil ikke bli koblet til din person eller organisasjon.

Din organisasjon vurderer selv hvem som skal fylle ut spørreskjemaet. Det krysses av i spørsmål 1 for hvilken rolle denne har.

\section{Hvilken rolle i organisasjonen har du som fyller ut spørreskjemaet?}

- Ansatt

- Leder

- Eier

- Annet, spesifiser 


\section{Hvilken sektor tilhører din organisasjon?}

- Offentlig sektor

- Privat sektor

- Tredje sektor

3. Hvilke(n) kategori(er) dekker best innsatsen(e) din organisasjon arbeider med? (velg én eller flere)

- Finansiering (f.eks. tilskudd, lån, risikokapital)

- Rådgivning/kompetanseutvikling (f. eks. mentoring, pro bonotjenester, kurs, veiledning)

- Inkubatorvirksomhet

- Nettverksbygging (f.eks. tilrettelegge for møteplasser, stille eget nettverk til disposisjon)

- FoU (forskning og utviklingsarbeid)

- Utdanning (alle nivåer av utdanning)

- Synliggjøring (f.eks. kunnskapsspredning generelt, synliggjøring av spesielle aktører)

- Lobbing (forsøk på å påvirke offentlig politikk)

- Juridiske rammeverk (utvikling og forvaltning av lov- og regelverk)

- Strategier og planer/strategisk utviklingsarbeid

- Ivaretakelse av foretaks/bedrifters interesser

- Annet

4. Har innsatsen(e) et navn? I så fall, nevn dette/disse?

5. Hva er overordnet formål for innsatsen(e)? Beskriv bakgrunnen for innsatsen(e), målgruppe og hvilke mål/resultater innsatsen(e) forsøker å nå. Legg gjerne ved link til nettsider m.m. 
6. Hva er innsatsen(e)s innhold? Beskriv hvilke (konkrete) aktiviteter innsatsen(e) består av?

7. Hvor lang tid har innsatsen(e) blitt tilbudt?

9. Hvordan finansieres innsatsen(e)? (velg én eller flere)

- Ved midler over offentlige budsjetter

- Ved midler fra private investorer

- Ved midler fra privat fond

- Ved betaling fra brukere/mottakere av innsatsen

- Annet, spesifiser

10. Hvis aktuelt, kan du nevne viktige samarbeidspartnere for gjennomføring av innsatsen(e)?

11.I hvilken grad fokuserer innsatsen(e) på følgende?

- Utvikle og prøve ut nye løsninger

- Utvikle løsninger som involverer målgruppen for det sosiale entreprenøriske arbeidet

- Stimulere til samarbeid på tvers av fagfelt og virksomhetsmodeller

- Utvikle bærekraft (både økonomisk og samfunnsøkonomisk)

- Andre kjennetegn

(for hvert punkt velges en av følgende kategorier; ikke spesielt, til en viss grad, i stor grad, vet ikke) 
12. Hvis aktuelt, på hvilken måte fokuserer innsatsen(e) på å utvikle og prøve ut nye løsninger?

13. Hvis aktuelt, på hvilken måte fokuserer innsatsen(e) på løsninger som involverer målgruppen for det sosiale entreprenøriske arbeidet?

14. Hvis aktuelt, på hvilken måte fokuserer innsatsen(e) på løsninger som stimulere til samarbeid på tvers av fagfelt og virksomhetsmodeller?

15. Hvis aktuelt, på hvilken måte fokuserer innsatsen(e) på løsninger som er bærekraftig (både økonomisk og samfunnsøkonomisk?

16. Hva er etter din vurdering i dag de største hindre for utvikling av sosialt entreprenørskap og sosial innovasjon i arbeidet for å inkludere utsatte grupper i arbeid og samfunnsliv i eget land?

17. Hvilke nye innsatser (både i offentlig og annen regi) for å legge til rette for sosialt entreprenørskap og sosial innovasjon i arbeidet for å inkludere utsatte grupper i arbeid og samfunnsliv er det etter din vurdering behov for i eget land? 
18. Kjenner du til viktige innsatser for å legge til rette for sosialt entreprenørskap og/eller sosial innovasjon som du mener bør inkluderes i denne kartleggingen? Kan du nevne navn på ansvarlig for disse? 
Ved Stranden 18

DK-1061 København K

www.norden.org

\section{Sosialt entreprenørskap og sosial innovasjon}

De nordiske landene står i dag overfor utfordringer knyttet til å opprettholde og videreutvikle den sosiale velferden. Nordisk Ministerråd besluttet på denne bakgrunn høsten 2013 å nedsette i arbeidsgruppe som fikk i oppdrag å kartlegge innsatser for sosialt entreprenørskap og sosial innovasjon i de nordiske landene. Hovedmålet for kartleggingen var å øke kunnskapen om innsatser i Norden for sosialt entreprenørskap og sosial innovasjon i arbeidet med å inkludere utsatte grupper i arbeid og samfunnsliv. I denne rapporten presenteres resultater fra den gjennomførte kartleggingen, og arbeidsgruppens anbefalinger til videre oppfølging.

- et program for nye velferdsløsninger for mennesker i Norden

TemaNord 2015:502

ISBN 978-92-893-3898-1 (PRINT)

ISBN 978-92-893-3899-8 (PDF)

ISBN 978-92-893-3900-1 (EPUB)

ISSN 0908-6692

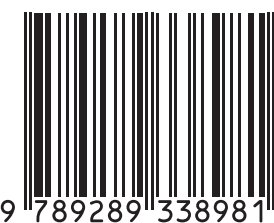

